\title{
THE IMPACT OF MOBILITY AND MIGRATION IN THE ROMAN EMPIRE
}

Proceedings of the Twelfth Workshop of the International Network Impact of Empire (Rome, June 17-19, 2015)

\section{Edited by}

Elio Lo Cascio and Laurens E. Tacoma, with the assistance of Miriam J. Groen-Vallinga 
The Impact of Mobility and Migration in the Roman Empire 


\title{
Impact of Empire
}

ROMAN EMPIRE, C. 200 B.C.-A.D. 476

\author{
Edited by \\ Olivier Hekster \\ (Radboud University, Nijmegen, The Netherlands)
}

\author{
Editorial Board \\ Angelos Chaniotis \\ Ségolène Demougin \\ Lien Foubert \\ Anne Kolb \\ Luuk de Ligt \\ Elio Lo Cascio \\ Bernhard Palme \\ Michael Peachin \\ Christian Witschel \\ Greg Woolf
}

VOLUME 22

The titles published in this series are listed at brill.com/imem 


\title{
The Impact of Mobility and Migration in the Roman Empire
}

\author{
Proceedings of the Twelfth Workshop of the \\ International Network Impact of Empire \\ (Rome, June 17-19, 2015)
}

\author{
Edited by \\ Elio Lo Cascio \\ Laurens E. Tacoma
}

with the assistance of

Miriam J. Groen-Vallinga

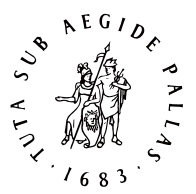

B R I L L 


\section{\begin{tabular}{|l|}
\hline B R I L L \\
\hline OPE N
\end{tabular}}

This is an open access title distributed under the terms of the CC-BY-NC 4.0 License, which permits any non-commercial use, distribution, and reproduction in any medium, provided the original author(s) and source are credited.

The Library of Congress Cataloging-in-Publication Data is available online at http://catalog.loc.gov LC record available at http://lccn.loc.gov/2016040216

Typeface for the Latin, Greek, and Cyrillic scripts: "Brill". See and download: brill.com/brill-typeface.

\section{ISSN 1572-0500}

ISBN 978-90-04-33477-9 (hardback)

ISBN 978-90-04-33480-9 (e-book)

Copyright 2017 by Koninklijke Brill NV, Leiden, The Netherlands.

Koninklijke Brill NV incorporates the imprints Brill, Brill Hes \& De Graaf, Brill Nijhoff, Brill Rodopi and Hotei Publishing.

All rights reserved. No part of this publication may be reproduced, translated, stored in a retrieval system, or transmitted in any form or by any means, electronic, mechanical, photocopying, recording or otherwise, without prior written permission from the publisher.

Authorization to photocopy items for internal or personal use is granted by Koninklijke Brill NV provided that the appropriate fees are paid directly to The Copyright Clearance Center, 222 Rosewood Drive, Suite 910, Danvers, MA 01923, USA. Fees are subject to change.

This book is printed on acid-free paper and produced in a sustainable manner. 


\section{Contents}

Preface VII

Olivier Hekster

List of Figures and Tables VIII

List of Contributors IX

1 Writing Migration 1

Laurens E. Tacoma and Elio Lo Cascio

2 Moving Peoples in the Early Roman Empire 25

Greg Woolf

3 Invasions, Deportations, and Repopulation: Mobility and Migration in Thrace, Moesia Inferior, and Dacia in the Third Quarter of the Third Century AD 42

Lukas de Blois

4 Viri Militares Moving from West to East in Two Crisis Years

(AD 133 and 162) 55

Anthony R. Birley

5 Die Mobilität Römischer Soldaten in Friedenszeiten 80 Peter Herz

6 Ordo Senatorius und Mobilität: Auswirkungen und Konsequenzen im Imperium Romanum 100

Werner Eck

7 Diplomatic Mobility and Persuasion between Rome and the West (I-II AD) $\quad 116$

Elena Torregaray Pagola

8 Bones, Stones, and Monica: Isola Sacra Revisited 132

Laurens E. Tacoma

9 Between Mobility and Connectivity in the Ancient Mediterranean:

Coast-Skirting Travellers in the Southern Levant 155

Gil Gambash 
10 The Dangers of Female Mobility in Roman Imperial Times 173 Margherita Carucci

11 The linouphoi of P. Giss. 40 I I Revisited: Applying the Sociological Concept of Ethnic Colonies to Alexandria's Linen-Weavers 191 Elena Koestner

12 Coloni et incolae, vingt ans après: Mobilité et identité sociales et juridiques dans le monde romain occidental $\quad 205$

Stéphane Benoist

13 Migration et droit dans l'Empire Romain: Catégories, contrôles et intégration 222

Claudia Moatti

Index Nominum 247

Index Geographicus $\quad 251$

Index Rerum 255

Index Locorum $\quad 258$ 


\section{Preface}

Olivier Hekster

Following on previous workshops of the Impact of Empire network which looked successively at frontiers (Impact 9, Durham), integration (Impact 10, Lille) and the world(s) beyond the borders of the Roman empire (Impact 11, New York), the twelfth meeting of the network focused on movement within the Roman world by studying the impact of migration and mobility. The theme was first suggested, and pays tribute to, the research focus of Elio Lo Cascio, who has been a longstanding board member of this network. The subject of the workshop, and its call for papers, was further developed by him in collaboration with Andrea Giardina, Nathalie de Haan and Olivier Hekster. The four of them formed the organisational committee of this workshop.

The workshop took place at Rome in June 17-19, 2015. Its meetings were hosted in the convivial surroundings of three separate venues: La Sapienza Università di Roma, the Royal Netherlands Institute of Rome and the Istituto Italiano per la Storia Antica, all of which institutes also assisted the workshop financially. Further financial support was kindly given by the Ministero dell'Istruzione, dell'Università e della Ricerca (MIUR), the Radboud University, and the Research School oikos. The organisers would like to thank all these organisations for their help; in addition the British School at Rome and the École française de Rome are thanked for their aid.

This workshop could not have taken place without the organisational skills and energy of Nathalie de Haan and especially Mattia Balbo. Their efforts formed a major factor in ensuring that the workshop was a success. The editors are, furthermore, grateful to Miriam Groen-Vallinga, for her enormous support in getting this volume in print rapidly.

For various reasons some participants could not contribute to the volume. Wim Broekaert, Anne Hunnell Chen, Andreas Goltz, Vana Kalenderian, Egbert Koops, Erika Manders, Günther Schörner, Frederik J. Vervaet and Andrea Zerbini are thanked for sharing their work and discussing that of others at the conference.

June 2016, Nijmegen 


\section{List of Figures and Tables}

\section{Figures}

3.1 Map of the Roman Balkans in the third century AD 44

5.1 Schema 1: Mobilität innerhalb der Heimatprovinz 82

5.2 Schema 2: Mobilität außerhalb der Provinz 86

5.3 Schema 3: Einsatz in der offiziellen Kommunikation 93

9.1 A plan of Tel Dor, its bays, and the Tantura lagoon $\quad 171$

\section{Tables}

8.1 Table 1: Isola Sacra data 137

9.1 Table 1: Shipwreck archaeology in Israel 172

9.1 Table 2: The late antique shipwrecks of Dor 172 


\section{List of Contributors}

Stéphane Benoist

Ph.D. (1992, Paris-Sorbonne: La Fête à Rome au premier siècle de l'Empire, 1999) and Habilitation (2001, Panthéon-Sorbonne: Rome, le prince et la Cité, 2005), is currently Professor of Roman History at the University of Lille (Humanities and Social Sciences, France). He has extensively published on imperial power, political discourses and conception of memory, festival and ceremonies in the city of Rome. About the perception of the City and its Empire, a general overview is provided in 5 CD's Une histoire de Rome (2015), to be published as a book (Puf, autumn 2016).

Anthony R. Birley

was professor of ancient history at Manchester from 1974 to 1990 and at Düsseldorf from 1990 to 2002, when he retired; since then he has been visiting professor at Newcastle and honorary professor at Durham. He has written five books on Roman Britain and biographies of the emperors Hadrian, Marcus Aurelius, and Septimius Severus; he has also edited volumes 3-7 of Roman Papers by his former teacher, Sir Ronald Syme, and two posthumously published monographs by Syme, Anatolica (1995) and The Provincial at Rome (1999). His research is still focused on prosopography, epigraphy and the Roman army.

\section{Lukas de Blois}

is emeritus professor of Ancient History of the Radboud University at Nijmegen in The Netherlands. He published books and articles on the history of the Roman Empire in the third century AD, the history of the Late Roman Republic, ancient historiography (Sallust, Tacitus, Cassius Dio), Plutarch's biographies, and Greek Sicily in the fourth century BC. He also published a manual (L. de Blois \& R.J. van der Spek, Introduction to the Ancient World, LondonNew York, 2nd edition, 2008).

\section{Margherita Carucci}

was a Research Fellow at the Helsinki Collegium for Advanced Studies, Finland. She has published a number of articles on a variety of aspects of the GraecoRoman society, such as visual art, gender studies, sculpture, and urbanism, with particular focus on social and cultural history. Her specific interests are on a wide range of aspects related to the Roman family, with particular focus on 
the daily experience of Roman women. She is currently working on gendered discourse on travel in ancient Roman society.

\section{Werner Eck}

was a member of the Philosophical Faculty at the University of Cologne. Since 2007 he is emeritus. Dr. h.c. of the University of Cluj, the University of Kassel and the Hebrew University of Jerusalem. At present he is engaged in the publication of the Corpus Inscriptionum Iudaeae/Palaestinae, the Corpus Inscriptionum Latinarum at Berlin and the History of Cologne in 13 volumes. He is one of the editors of the Zeitschrift für Papyrologie und Epigraphik. His central research topics are the history of the Roman Empire (including the history of early Christianity), especially the provinces and in particular of Germania superior and inferior and Judaea; Roman social and administrative history; Roman epigraphy. For his publications see: http://histinst.phil-fak.uni-koeln .de/index.php?id=309.

\section{Gil Gambash}

is the chair of the Department of Maritime Civilizations at the University of Haifa, and the head of the Haifa Centre for Mediterranean History. His current research interests centre on ancient Mediterranean empires, particularly with regard to aspects of maritime connectivity, mobility, and logistics. Recent publications include 'Caesarea Maritima and the Grand Strategy of the Roman Empire,' Skyllis 13.1 (2013): 53-58; 'En Route to Egypt-Akko in the Persian Period,' JNES 73.2 (2014): 273-282; 'Maritime Activity in the Ancient Southern Levant: The Case of Late Antique Dor,' ARAM 27 (2015): 61-74.

\section{Peter Herz}

studied history, classics and archaeology at Mainz and Oxford (1968-1975). Doctor in Ancient History (Mainz 1975); state examination in history and Latin 1976; 2nd examination 1978; travel scholarship of the Deutsches Archäologisches Institut 1978/79. Assistant Mainz 1980-85; Habilitation Mainz 1985; Professor Mainz 1986; Institute for Advanced Study Princeton 1990; Chair for Ancient History Regensburg 1994-2014. Emeritus since 2014. His main fields of research are Latin epigraphy; social and economic history (esp. of the Roman empire); ancient religions (ruler cult).

\section{Elena Koestner}

After studying History, German Philology and Pre- and Protohistoric Archaeology at the Universities of Bayreuth and Regensburg (Germany) Elena Koestner completed her studies with the $\mathrm{PhD}$-thesis supervised by Prof. Dr. Peter Herz combining archaeological with historical methods to 
analyse the intercultural relations between Romans and Celts in the civitas Treverorum in the first centuries BC and AD (published 2011). Since October 2012 she is a postdoctoral researcher at the chair of Ancient History at the University of Regensburg. Her main research project deals with interpersonal relationships mentioned in Roman last wills by using Social Network Analysis.

\section{Elio Lo Cascio}

is Professor of Roman history at Sapienza Università di Roma. His main areas of research are the institutional, administrative and economic history of Rome, and Roman population history. His recent publications include Il princeps e il suo impero. Studi di storia amministrativa e finanziaria romana (2000); Crescita e declino. Studi di storia dell'economia romana (2009), and the edited volumes Roma imperiale. Una metropoli antica (2000) and L'impatto della "peste antonina" (2012).

\section{Claudia Moatti}

is professor at the Paris 8 and at the University of Southern California. She has studied the intellectual transformations of the Roman society at the end of the Republic (The Birth of Critical Thinking in Republican Rome, Cambridge University Press, 2015 = Paris, 1997), the Roman land archives (Archives et partage de la terre dans le monde romain, 1993) and the control of human mobility in the Roman Empire. This last research developed within a broader international program she has been heading, La mobilité des personnes en Méditerranée, de l'Antiquité à l'époque moderne. Procédures de contrôle et documents d'identification which culminated in her three edited volumes. Her current projects examine the concept of res publica (Res publica. Histoire discontinue de la chose, to be published), and the "cosmopolitisation" of the Roman Empire (Mobility, Law and Identity in the Roman Empire).

\section{Laurens E. Tacoma}

is lecturer in Ancient History at Leiden University. He has written about Roman social mobility, demography, economy and labour, local elites and urbanisation. More recently, he worked in a larger research project entitled 'Moving Romans. Migration, Labour and Urbanisation in Roman Italy'; one of its outcomes is his recent monograph Moving Romans. Migration to Rome in the Principate (Oxford 2016). New research concerns Roman political culture in Italy from the Principate to Late Antiquity.

\section{Elena Torregaray Pagola}

is a Roman historian, lecturer in the Department of Classics at the University of the Basque Country (Spain), whose research interests include the international 
relations, diplomatic culture and political communication of the Republic and early Empire. She has recently written a paper on Scipio Aemilianus' Eastern embassy and she currently works on diplomatic mobility in war zones during the Roman conquest of Mediterranean. Her next project will tackle the diplomatic activity of women of the Republic and early Empire.

\section{Greg Woolf}

is Director of the Institute of Classical Studies in London. He has published extensively in the field of Roman social, religious and cultural history. His books include Becoming Roman (1998), Tales of the Barbarians (2011) and Rome. An Empire's Story (2012). He is currently working on the naturalness of ancient urbanism and a book on diasporas and colonisation in antiquity. 


\title{
Writing Migration ${ }^{1}$
}

\author{
Laurens E. Tacoma and Elio Lo Cascio
}

\section{1 \\ The View from Monte Cassino}

Somewhere towards the end of his long life Paul the Deacon (c.720/30798/9 AD), monk, intellectual, and prolific writer, sat down in his monastery at Monte Cassino to look back on the history of his people, the Langobards. The Langobards had entered Italy in AD 568 in the midst of wars between the Byzantines and the remnants of the Ostrogothic kingdom. They had quickly established themselves as a major power, but in AD 774 they had to cede great parts of their Italian territory to the Franks and by the time Paul wrote their hold was reduced to a number of smaller kingdoms. Paul himself hailed from a Langobard aristocratic family in Friuli on the north coast of the Adriatic and was well connected both to the Langobard and the Frankish courts. In the first book of his Historia Langobardorum he sketched the Werdegang of the Langobards, which, like so many other peoples before them, originated from the north and had moved southwards to arrive after a century-long journey in Italy. Paul's narrative structure was closely modelled on that of his predecessors; his work is a classic example of an origo gentis. ${ }^{2}$

Paul opened his work with a remarkable generalisation:

Septemtrionalis plaga quanto magis ab aestu solis remota est et nivali frigore gelida, tanto salubrior corporibus hominum et propagandis est gentibus coaptata; sicut econtra omnis meridiana regio, quo solis est fervori vicinior, eo semper morbis habundat et educandis minus est apta mortalibus. Unde fit, ut tantae populorum multitudines arctoo sub axe oriantur, ut non inmerito universa illa regio Tanai tenus usque ad occiduum, licet et propriis loca in ea singula nuncupentur nominibus, generali tamen vocabulo Germania vocitetur; quamvis et duas ultra Rhenum provincias Romani, cum ea loca occupassent, superiorem inferioremque Germaniam dixerint.

1 Our thanks to Miriam J. Groen-Vallinga for constructive criticism, to Marilyn Hedges for correcting the English, and to Olivier Hekster for further advice.

2 For general analysis see W.A. Goffart, The Narrators of Barbarian History (A.D. 550-8oo): Jordanes, Gregory of Tours, Bede, and Paul the Deacon (Princeton 1988). 
Ab hac ergo populosa Germania saepe innumerabiles captivorum turmae abductae meridianis populis pretio distrahuntur. Multae quoque ex ea, pro eo quod tantos mortalium germinat, quantos alere vix sufficit, saepe gentes egressae sunt, quae nihilominus et partes Asiae, sed maxime sibi contiguam Europam afflixerunt. Testantur hoc ubique urbes erutae per totam Illyricum Galliamque, sed maxime miserae Italiae, quae paene omnium illarum est gentium experta saevitiam.

The region of the north, in proportion as it is removed from the heat of the sun and is chilled with snow and frost, is so much more healthful to the bodies of men and fitted for the propagation of nations, just as, on the other hand, every southern region, the nearer it is to the heat of the sun, the more it abounds in diseases and is less fitted for the bringing up of the human race. From this it happens that such great multitudes of peoples spring up in the north, and that that entire region from the Tanais (Don) to the west is not improperly called by the general name of Germany, although single places in it are designated by their own names. The Romans, however, when they occupied those parts, called the two provinces beyond the Rhine, Upper and Lower Germany. From this teeming Germany, then, innumerable troops of captives are often led away and sold for gain to the people of the South. And for the reason that it brings forth so many human beings that it can scarcely nourish them, many nations have emigrated from it, nations that have indeed become the scourge of portions of Asia, but especially of the parts of Europe which lie next to it. Everywhere ruined cities throughout all Illyria and Gaul testify to this, but most of all in unhappy Italy which has felt the cruel rage of nearly all these nations. ${ }^{3}$

The passage might serve as a showcase for Paul's lively style. It also shows what types of knowledge were produced in post-classical times about what had by then become the distant past. For a man of his times, Paul was well versed in Roman history; he had previously written a Historia Romana in which he had reworked Eutropius' Breviarium. ${ }^{4}$ It is interesting to see how Paul thought about migration in the Roman past.

The generic, law-like statement is neither chronologically nor geographically specific. The centuries are collapsed into a single, undifferentiated

3 Paul the Deacon, Historia Langobardorum 1.1. Ed. $M G H$ 1878, transl. adapted from P. Foulke (New York 1907).

4 See M. Maskarinec, 'Who were the Romans? Shifting scripts of Romanness in early medieval Italy', in W. Pohl and G. Heydemann, eds., Post-Christian Traditions: Christian and Barbarian Identities in the Early Medieval West (Turnhout 2013), 297-364. 
Roman past. Geographically, Paul's Germania is strikingly large, 'from the Don to the west', and it included Scandinavia, purportedly the homeland of the Langobards. Although Paul does refer to the creation of the Roman provinces, Germania seems at a conceptual level to remain geographically a separate sphere. Migrants are in this spatial concept externals who move into the empire.

The passage presents a mix of climatological and geographical determinism and Malthusian thought avant la lettre. Migration is in Paul's view caused by population pressure. Population growth is in its turn the result of climatological conditions: in what would nowadays be considered a rather paradoxical argument, the northern areas are presented as the most healthy regions because they lack sunshine. A cold climate is a healthy one, Paul holds, and this finds expression in population growth. But as the population starts to outstrip the available resources, people are forced out of the region.

Paul distinguished two basic types of migration: what we would nowadays call forced and voluntary migration. The forced migration consisted of slavery: captives were taken away and sold for money. The voluntary migration concerned groups that themselves decided to move, though their free will remained the result of a force outside their control: their territory was not capable of producing sufficient food. In both the voluntary and the forced forms of migration the movement was collective: although Paul might have been aware that mass enslavement could result in sales of individuals, he speaks of groups, not of individuals.

Underlying Paul's discussion there may have been a moral judgement about the impact of migration. Although there is a risk of overinterpretation, implicitly it seems to have had in the passage a negative connotation. Either groups were captured and sold, as passive victims, and their migration was a consequence of their enslavement. If groups decided to move of their own volition, they started to plunder and destroy cities, and migration led to devastation of the land.

The position of the passage at the very beginning of his work is in itself sufficient to demonstrate that migration and mobility were at the heart of this type of history writing. ${ }^{5}$ The attempt to carve out a space for the Langobards in Italy led almost inevitably to musings on migration and mobility in the past. The passage formed the narrative engine for the book; it set the Langobards almost literally in motion.

Obviously the text is primarily relevant as an analysis of the Völkerwanderung. But it is in that respect interesting to see how seriously the passage has been taken in the past. For F. Dahn in 1880, it formed the best example (if not

5 See Maskarinec 2013, op. cit. (n. 4) for the argument that Paul even (re)constructed Roman history in his Historia Romana in very similar terms. 
the basis) for his structural analysis of the causes of the migrations of Late Antiquity. ${ }^{6}$ And indirectly one might argue that in a more general way it informed conceptualisations of Roman migration. Although there is no direct influence from Paul on later thinking about migration, his type of conceptualisation has been highly influential. In fact, many of Paul's concepts can even be found in twentieth-century discussions of Roman migration. Migration has often been conceptualised as a collective phenomenon by outsiders entering the empire in cross-border movements. It consisted mainly of two types: either captive slaves or peoples who themselves decided to move. It was seen mainly as the result of push factors, often the result of population pressure or some other external factor. It was also frequently seen as a negative force.

\section{Roman Reflections}

Paul's passage has an intrinsic interest, but it also serves to highlight what we cannot hope to find in the Roman authors: a rigorous and comprehensive "theory of migration". Although elements like Paul's geographical determinism can easily be traced back to Roman ethnographic thinking, ${ }^{7}$ explicit reflections on the nature and causes of migration in the early imperial period are, with some noteworthy exceptions, virtually absent.

This virtual absence might be due in part to the conventions of the literary genre or to the type of history writing. Paul the Deacon belonged to a historiographical tradition that only rose to prominence in Late Antiquity. It is characterised by a specific perspective of its authors: they presented the history of their ethnic group to a Roman audience. It thus purported to offer an insider's perspective to an outsider's audience-no matter how blurred these categories were in reality. ${ }^{8}$ In earlier Roman times Flavius Josephus used a similar perspective in his works on Jewish history. But whereas Paul in the eighth century was part of a tradition that was already some centuries old, Josephus in the early Roman period was more or less alone. Moreover, although his history of the Jews is obviously closely connected to the Jewish diaspora, movement

6 F. Dahn, discussing Die Ursachen der Völkerwanderung in his 'Einleitung der neuen Auflage' to his revision of E. von Wietersheim, Geschichte der Völkerwanderung (Leipzig $1880^{2}$ ), esp. 12. Obviously, modern perspectives differ significantly; a good though highly polemical starting point is offered by G. Halsall, "Two worlds become one: a "counter-intuitive" view of the Roman empire and "Germanic" migration', German History 32 (2014), 512-532.

7 See P. Amory, People and identity in Ostrogothic Italy, 489-554 (Cambridge 1997), 19-20 on geographical determinism in ancient ethnography.

8 Goffart 1988, op. cit. (n. 2), 5 . 
as such does not seem to be as central to Josephus' concerns as it was to the late-antique authors.

It was not that the Romans were unaware of the importance of mobility. In fact, they liked to point out that the very origins of Rome were grounded in the arrival of newcomers. One example concerns the use of the argument by the emperor Claudius in his speech about the admission of Gallic nobles in the Roman senate. ${ }^{9}$ Have we not always, Claudius asked the senators, from the very beginning of Roman history given foreigners access to our community? Is the strength of our community not based on the admission of outsiders? Historical precedent was used to legitimate present policies and to show that admitting newcomers to the Senate was no innovation. The argument itself certainly did not go unopposed, but it nonetheless formed a line of thinking that could be, and was taken. ${ }^{10}$

A distant echo of these ideas can be found at the end of antiquity. Aurelius Victor, after he had sketched a brief history of the Julio-Claudian and Flavian dynasties, referred in a flight of abstract historical generalisation just like Claudius to archaic times:

Hactenus Romae seu per Italiam orti imperium rexere, hinc advenae quoque; nescio an ut in Prisco Tarquinio longe meliores. Ac mihi quidem audienti multa legentique plane compertum urbem Romam externorum virtute atque insitivis artibus praecipue crevisse.

Up to this time men born at Rome or in Italy had ruled the empire, afterwards foreigners did, too; perhaps, as was the case with Tarquinius Priscus, they were far better. And to me at least, from the many things I have heard and read, it is perfectly clear that the city of Rome grew great in particular through the qualities of outsiders and imported talents. ${ }^{11}$

Aurelius Victor's passage is striking for its positive tone. Urban growth and the prosperity of the empire are due to the qualities of outsiders, to the immigration of talented people. Yet its imagery is part of a two-sided coin: the contribution of outsiders was valued in moral terms. As happened often with such judgements in antiquity, these could be both positive and negative. ${ }^{12}$

$9 \quad$ CIL 13.1668 (the Lyon tabula) and Tac. Ann. 11.23-25.

10 A. Giardina, L'Italia Romana. Storie di un'identità incompiuta (Rome and Bari 1997), 3-17.

11 Aur. Victor, De Caes. 11 (transl. H.W. Bird, Liverpool Translated Texts for Historians 17, 1994).

12 D. Noy, Foreigners at Rome. Citizens and Strangers (London 2000), 31-36 for an overview. For the important positive evaluation of Aelius Aristides, see E. Lo Cascio, 'Roma come 
The most famous of the negative appreciations is surely that of Juvenal. Many of his satires focus on outsider intrusion. In his most celebrated work, the Third Satire, poverty-stricken, hard-working Roman Umbricius loads all his belongings on a cart and leaves Rome in disgust, complaining that no space is left for him due to the intrusion of Greeks and Syrians.

The text has been cited very often, and its imagery is extremely forceful. In an influential article in 1916, Tenney Frank purported to test whether what Juvenal said was right, but in fact took over many of the pejorative connotations that Juvenal inserted into his verses (and added some more of his own). ${ }^{13}$ Other historians have been more cautious, but still considered Juvenal's statements to contain at least a kernel of truth about the resentment Romans felt about the Orontes flowing into the Tiber. However, literary studies of Juvenal have tended to complicate matters. The crucial point is that Umbricius' standing in the Satire is 'compromised in more than one way'; Umbricius is portrayed as ranting. ${ }^{14}$ Juvenal leaves the reader in the dark about what to think. At most, the satire can be understood as an exploration on what possible responses to foreign presence could be, but not necessarily as an invitation to the reader to endorse such a view.

The most profound reflections on mobility came from a different genre: that of Roman exilium literature. In particular two chapters in Seneca's Ad Helviam, a letter of condolence to his mother on his exile, are often cited.

Aspice agedum hanc frequentiam, cui uix urbis inmensae tecta sufficiunt: maxima pars istius turbae patria caret. Ex municipiis et coloniis suis, ex toto denique orbe terrarum confluxerunt: alios adduxit ambitio, alios necessitas officii publici, alios inposita legatio, alios luxuria opportunum et opulentum uitiis locum quaerens, alios liberalium studiorum cupiditas, alios spectacula; quosdam traxit amicitia, quosdam industria laxam ostendendae uirtuti nancta materiam; quidam uenalem formam attulerunt, quidam uenalem eloquentiam.

But look at this mass of people, for whom the number of houses of the immense City hardly suffices: the largest part of this crowd lacks a

"mercato comune del genere umano"', in P. Desideri and F. Fontanella, eds., Elio Aristide e la legittimazione greca dell'impero di Roma (Bologna 2013) 185-201.

13 T. Frank, 'Race mixture in the Roman Empire', American Historical Review 21 (1916), 689-708.

14 C. Edwards, Writing Rome. Textual Approaches to the City (Cambridge 1996), 125-129, quote at 127 . 
fatherland. From their municipia and colonies, from the whole world they have streamed together. Some have been brought by ambition, some by the requirements of public office, some by an embassy that was imposed upon them, some by luxury, searching a convenient and rich place for their vices, some by the wish to study, some by the spectacles; others are drawn by friendship, others by zeal, finding ample opportunity to display virtue; some have brought beauty for sale, some eloquence for sale. ${ }^{15}$

A caelestibus agedum te ad humana conuerte: uidebis gentes populosque uniuersos mutasse sedem (...) Liberos coniugesque et graues senio parentes traxerunt. Alii longo errore iactati non iudicio elegerunt locum sed lassitudine proximum occupauerunt, alii armis sibi ius in aliena terra fecerunt; quasdam gentes, cum ignota peterent, mare hausit, quaedam ibi consederunt ubi illas rerum omnium inopia deposuit. Nec omnibus eadem causa relinquendi quaerendique patriam fuit: alios excidia urbium suarum hostilibus armis elapsos in aliena spoliatos suis expulerunt; alios domestica seditio summouit; alios nimia superfluentis populi frequentia ad exonerandas uires emisit; alios pestilentia aut frequentes terrarum hiatus aut aliqua intoleranda infelicis soli uitia eiecerunt; quosdam fertilis orae et in maius laudatae fama corrupit.

Come now, turn your attention from things divine to the affairs of men; you will see that whole tribes and nations have changed their abodes. (...) Wives and children and elders burdened with age trailed along. Some have not settled upon a place from choice, but, tossed about in long wandering, from very weariness have seized upon the nearest; others have established their right in a foreign land by the sword; some tribes, seeking unknown regions, were swallowed up by the sea; some settled in the spot in which a lack of supplies had stranded them. And not all have had the same reason for leaving their country and seeking a new one. Some, having escaped the destruction of their cities by the forces of the enemy, have been thrust into strange lands when stripped of their own; some have been cast out by civil discord; some have gone forth in order to relieve the pressure from over-crowding caused by an excess of population; some have been driven out by pestilence or repeated earthquakes or 
certain unbearable defects of an unproductive soil; some have been beguiled by the fame of a fertile shore that was too highly praised. ${ }^{16}$

Seneca is one of the few authors to discuss motives for migration, and for that reason alone his testimony deserves full attention. In the former passage, referring to the growth of the city of Rome that was the result of immigration, he lists a series of "pull factors" which attract individual migrants. In the latter one, he enlarges his perspective to migration of gentes and populi, and now the stress is on what we can call "push factors". Both the former and the latter lists are certainly far from exhaustive. At the same time, it is clear that the context of the two passages is rhetorical, and that the former text presents an elite perspective. The most striking element for a modern observer is that Seneca seems to omit labour from his long list of motives. Historians of migration agree that labour is in most historical periods the major impetus for migration, and it was certainly so also in the case of individual migration to Rome. But it would be improper to expect an allusion to labour in general in a society in which there was no unitary and abstract idea of labour (and, for that matter, no word in the Latin language for it). ${ }^{17}$ Moreover, according to the elite perspective as it is expressed in a famous passage of Cicero's de officiis, ${ }^{18}$ there was a clear divide between the honourable artes or artificia and the quaestus, which are sordidi: and a hint to the former could be in the allusion to the "industria laxam ostendendae uirtuti nancta materiam", which induces certain people to migrate to Rome. In any case it would be methodologically unsafe to base too much on Seneca's enlistment of migration motives alone, no matter how perceptive his comments are in other respects. ${ }^{19}$

Roman reflections are thus not absent, but the Romans hardly reflected on migration as an independent phenomenon. Their reflections concerned other issues. For all their differences, the passages just quoted might all be read as explorations of the consequences of migration for Roman identity rather than being about migration itself. Mobility appears to be taken as a given, but the authors addressed the question what it implied socially and culturally. What did being away from Rome mean? What did the influx of foreigners imply for Romanness in the heart of the city? Who was regarded as Roman? Could citizenship be expanded at will? Could one be Roman while being relegated outside Rome?

16 Sen. Cons. ad Helv. 7.1; 3-4 (transl. J. Henderson Loeb Classical Library 1932).

17 See now M. De Nardis, 'Terminologia e concetto di lavoro nel mondo romano', in A. Marcone, ed., Storia del lavoro in Italia. I. L'età romana. Liberi, semiliberi e schiavi in una società premoderna (Roma 2016), 79-90.

18 Cic. De Off. 1.42.150-151.

19 Cf. Noy 2000, op. cit. (n. 12), 85-139. 
Of course, we do not have any real reason for complaint. The fact that Roman reflections on mobility are scarce does not mean that sources about mobility and migration are absent. In fact, Roman imperial history presents us with a surprising number of sources that attest to forms of mobility.

Three examples, from different periods and areas, may suffice to demonstrate their nature and the possibilities for analysis.

The first is an inscription from Ravenna on the Adriatic coast of North-East Italy. The text actually consists of two separate inscriptions written on the same slab, showing two different ways to inscribe mobility: the one implicit, the other explicit. The stone, about a metre high, contained the portrait of a woman with a text written below it. The first text, undated but stemming from the early imperial period, reads as follows: ${ }^{20}$

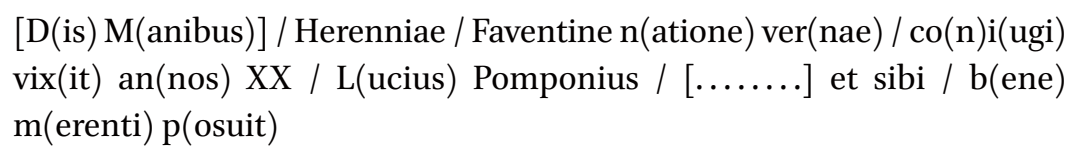

To the gods of the underworld. To Herennia Faventina, of local origin, his wife, who lived 20 years, well deserving; Lucius Pomponius [....... ] has placed (this memorial), also for himself.

The text of the inscription is in itself highly conventional: a husband erected a memorial for his deceased wife. The use of the phrase natione verna, 'of local origin', is remarkable, however. It is well known that the word verna was normally employed to indicate locally born slaves, in contrast to imported ones. Although verna was predominantly used alone, natione verna could be used in a similar way for slaves. ${ }^{21}$ However, Herennia Faventina was certainly not a slave. Her free status is indicated by her duo nomina; it should also be noted that she was described as a coniunx, a term normally reserved for a spouse in a legal Roman marriage. Although rare, the combination of natio with verna for a free person is not completely unknown. In fact, there are two more instances among the inscriptions of Ravenna. ${ }^{22}$ It is probably no coincidence that both

$20 \quad C I L 11.61$ (with p. 1227). The lacuna at the beginning in line 6 is given in the Clauss-Slaby database as three letters, but $C I L$ gives 8 ; it contained in all likelihood a cognomen.

21 For a (relatively early) certain case, see $C I L$ 1.2965a from Rome.

22 CIL 11.59: $D$ (is) M(anibus) / L(ucius) Fulvi(us) Sever(us) / scrib(a) III(triere) Vict(oria) / n(atione) vern(a) / vix(it) ann(os) XXXV / mil(itavit) an(nos) XVII / Volcenia Severa / et $C$ (aius) Volcena Titu(s) / h(eredes) p(onendum) c(uraverunt), "To the gods of the underworld. Lucius Fulvius Severus, clerk of the trireme Victoria, of local origin, he lived 35 
belong to a military context, and the same may be surmised in the case of the text discussed here. ${ }^{23}$ In military inscriptions, when names were written out in full, they almost invariably contained a reference to the origin of the individual. Natione (or a similar term like domo) was a standard element, followed by a region, a city or a tribe. Its formulaic use points to an expectation that soldiers originated elsewhere-as was of course the norm. The use of natione verna implies that a local origin was not the default option, but needed to be spelled out. In the case discussed here, this principle apparently even applied to wives. Implicitly it suggests that many people (including wives of soldiers) hailed from elsewhere.

Interestingly enough, the slab was reused in late antiquity, probably in the late fourth or early fifth century AD. The female portrait, the letters D.M. and what was probably the cognomen of the previous dedicator were partly erased (possibly the latter was a name with pagan overtones like Hermes). A new text was added, for a Christian migrant hailing from Africa. ${ }^{24}$

Caius Zobo/nis de lo(co) Kasen/se civis Afer qui / vixit annis quin/ quaginta vives / in pace

Gaius Zobonis, of the town Casae, African citizen, who lived fifty years. May you live in peace

years and served 17 years. Volcenia Severa and Gaius Volcena Titus, his heirs, have taken care that (this monument) was erected". cIL 11. 65: D(is) M(anibus) / M(arcus) Iulius / Maximus / optio III(triere) Victo(ria) / nat(ione) verna / vixit annis / XXXXVI mil(itavit) / annis XXVI / C(aius) Aulius / Successus / heres / b(ene) m(erenti) $p$ (onendum) c(uravit) / [, "To the gods of the Underworld. Marcus Julius Maximus, chief aide of the trireme Victoria, of local origin, he lived 46 years, he served 26 years. Gaius Aulius Successus, his heir, has taken care that (the monument) was erected, well deserving". See also e.g. $C I L$ 10.3646 for a veteran sailor at Misenum. Some discussion in C.G. Starr, The Roman imperial navy $3_{1}$ B.C.-A.D. 324 (3rd ed. Chicago 1993), 69-70, excluding slave origin in their case, and in particular idem, 'Verna', Classical Philology 37 (1942), 314-317, though whether as Starr seemed to think the phrase means in military contexts "born in the camp", equivalent to ex castris, rather than simply "from the local community" must remain open.

23 Most of the inscriptions of Ravenna of the early imperial period can be connected to the presence of the fleet. As it was common that dedicators gave much less information about themselves, the omission of a military function of Lucius Pomponius is not an obstacle, nor is the presence of a wife unusual, despite the formal prohibition for soldiers to marry. ILCV 4451b; cf. AE 2008, 531. 
The inscription was set up for a male immigrant from Casae in Numidia (mod. El. Madher in Algeria). Late-antique changes are visible in the Christian formula 'may you live in peace', and in the somewhat different formulae used to demarcate the origin of the deceased (locus and civis), while the lack of mention of a dedicator is also typically late antique. In addition the rather un-Roman name of Zobonis is remarkable. ${ }^{25}$ It cannot be inferred from the text what brought Zobonis to Ravenna. The character of Ravenna changed dramatically in the early fifth century when it became an imperial residence. As Ravenna lost its homogeneously military function, it might be expected that in Late Antiquity it attracted a far more diverse crowd of immigrants than it did before.

The second example comes from the other end of the empire and consists of a small passage in the New Testament. The New Testament is, in fact, full of mobile people. This applies in particular to Acts, ${ }^{26}$ but the Gospels too contain many vignettes of people who travelled, for various purposes. In the Gospel of Luke, the evangelist relates how Mary is visited by the Archangel Gabriel. Gabriel announces that she will have a son who is to be named Jesus. When Mary objects she is still a virgin, Gabriel comforts her by telling how her relative Elisabeth, who was thought to be infertile, was also with child. After the vision, Luke writes:

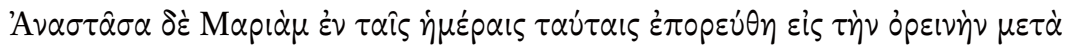

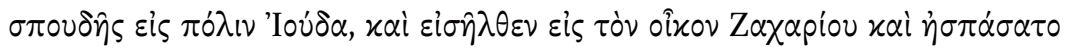
$\tau \dot{\eta} \nu^{\prime} \mathrm{E} \lambda \iota \sigma \dot{\beta} \beta \varepsilon \tau .{ }^{27}$

Then Mary got up and went with speed to the hill country, to a city in Juda, where she entered the house of Zacharia, and greeted Elisabeth.

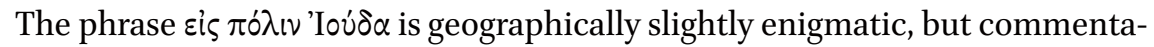
tors agree that it refers to the mountainous parts of Judaea. If they are correct, the implication must be that according to the Gospel Mary travelled on her own for a journey of three to four days to visit Elisabeth. ${ }^{28}$ Such details may be

\footnotetext{
25 The name does not occur elsewhere in the Clauss-Slaby database, and does not occur, for example, among the Roman Sklavennamen analysed by H. Solin.

26 D. Marguerat, The First Christian Historian. Writing the 'Acts of the Apostles' (Engl. transl. K. McKinney, G.J. Laughery and R. Bauckham) (Cambridge 2002), 231-256.

27 Luke 1: 39-40 (Nestle-Aland, 1991 ${ }^{12}$ ).

28 W. Wiefel, Das Evangelium nach Lukas (Theologischer Handkommentar zum Neuen Testament) (Berlin 1988), 54-55.
} 
rejected as unhistorical; we have after all just previously read about a vision, and the passage is part of a larger story in which a parallel is created between John the Baptist and Jesus at several levels. However, one could equally argue that the narrative strategy was to authenticate the miraculous by using plausible social and topographical details. Apparently, in the opinion of the readership, a young woman, engaged but not yet married, could with some degree of plausibility be presented as travelling on her own for a long distance, and making her own decisions about visiting relatives. It presents a social universe in which young unmarried women had a relatively large freedom of movement.

The third example is a marriage contract preserved on papyrus. In such texts a prospective couple (or their parents or guardians) made arrangements about the mutual obligations between the spouses, with particular reference to the dowry. The contract under consideration belonged to a Greek couple from Alexandria and dates to $12 / 11 \mathrm{BC}$. The obligations of the husband, Dionysios, to his wife Isidora were that he not mistreat her or abuse her or throw her out or bring another woman into (the house)'. For the wife Isidora, the following rules applied: she 'does not sleep away or be away for a day from Dionysios' house without Dionysios' approval, or damage the home, or be with another man.' ${ }^{29}$ The gendered differentiation between the obligations of husband and wife was a standard element in such marriage contracts. The husband's obligations were defined with respect to his wife; he was not to abuse her, physically or otherwise. The wife's obligations were formulated to protect the marriage and thereby her husband's reputation - there were all kinds of sexualised threats to the marriage which needed to be controlled. From a mobility perspective, the stipulation that Isidora was not to be away from the house without her husband's consent is noteworthy. It will have severely restricted her freedom of movement. Should we take it literally, or should we interpret the clause together with the other ones in a more abstract way? It suggests at the very least that the movement of this married woman was subject to her husband's control.

More examples could easily be found, including from other types of sources. Epigraphers have collected hundreds of inscriptions testifying to mobility; authors on ancient travel have brought together series of passages in which travellers appear, scholars of slavery have analysed how groups of slaves were

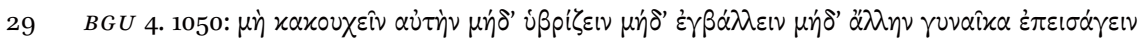

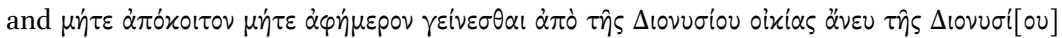

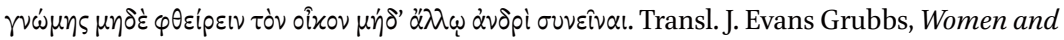
the Law in the Roman Empire: a Sourcebook on Marriage, Divorce and Widowhood (London and New York 2002), 123-125. 
moved throughout the empire. And besides the texts there is an enormous amount of material culture available that can be employed to analyse mobility: it varies from shipwrecks to ethnic grave goods, from amphorae that allow us to trace shifts in trade patterns to archaeological surveys attesting to increasing settlement clustering. They each offer tantalising insights.

The sources are thus abundant, but they are also highly fragmented and individualised. This makes it difficult to generalise. For example, all three texts just quoted are relevant for female mobility, but merging them into a single coherent framework proves difficult. The fragmentation can be explained in various ways. It may suggest diversity in types of mobility, different types of sources may emphasize different types of mobility, and there may be regional, social and chronological differences at work. These explanations are not mutually exclusive. The paradox is thus that there is an abundance of sources, but that there is no obvious analytical framework immediately at hand.

\section{$4 \quad$ In Search of Modern Migration Theory}

If the ancient sources do not themselves provide a narrative framework, the question then is what modern theory is there to help?

There cannot be any real doubt that The Corrupting Sea of Horden and Purcell has performed a seminal role in providing a framework. ${ }^{30}$ Any short description is incapable of doing justice to the richness of Horden and Purcell's arguments and the fullness with which they are documented. It offered a seminal contribution on how the ancient world worked, and a major conceptual apparatus to analyse it. The key concept of connectivity which they explore in their book has found wide acceptance. Connectivity is described as 'the various ways in which micro-regions cohere, both internally and also one with another. ${ }^{31}$ Notwithstanding the sometimes rather circumstantial formulations, the basic tenets of their model can easily be summarized. The ecology of the Mediterranean produced micro-regions that each had slightly different characteristics. Variations in rainfall led to variations in soil, in the fertility of the land, in crops, and, as a result, in population densities and settlement patterns. Such variations almost automatically led to risk-avoiding strategies among their populations, and, important for our purposes, to forms of redistribution and exchange. In consequence, the movement of goods and people

$30 \quad$ P. Horden and N. Purcell, The Corrupting Sea: a Study of Mediterranean History (Oxford 2000).

31 Horden and Purcell 200o, op. cit. (n. 30), 123. 
was a structural feature of the Mediterranean world. This was facilitated by the sea, which had the capacity to connect regions far apart from each other; the Mediterranean was thus 'the principal agent of connectivity'. ${ }^{32}$ As was observed by a commentator, Horden and Purcell 'insist that the essential unity of the Mediterranean is far less a reified thing than a process - the impetus to connect the disparate parts'. ${ }^{33}$

Yet Horden and Purcell's work is also criticised. ${ }^{34}$ The authors have certainly succeeded in producing an adaptable model that helps to describe a very significant chunk of history. However, its success is arguably also its major disadvantage. Their model fits so many situations that it does not provide enough direction to serve as a guide for further analysis. Moreover, as measurability and quantification are not at the forefront of the authors' concerns, it is difficult to prove or disprove the authors' assertions. ${ }^{35}$ Their wish to discard the traditional types of periodization has at a fundamental level-and quite paradoxical-produced a static world. And while their model does allow for the presence of institutions and politics, it does not accord a central role to it. The same applies to human agency. Their model might be helpful in analysing the Mediterranean world as a whole at a general level over a period of three millennia, but it works less well in describing the particulars of the Roman highly urbanised version of it. It is not well equipped to address the question in what ways connectivity intensified during the Roman period.

In principle, network analysis has the potential to offer a formal means for the study of Horden and Purcell's connectivity. Although its possibilities have not been explored to the full, moving beyond the metaphoric use of network terminology has as yet proven difficult. At present, its main use seems confined to the suggestion of non-hierarchical and non-unilateral flows of goods and people. ${ }^{36}$ This seems an elaboration upon the concept of connectivity rather than an analysis of it.

32 Horden and Purcell 2000, op. cit. (n. 30), 133.

33 B.D. Shaw, 'Challenging Braudel: a new vision of the Mediterranean', Journal of Roman Archaeology 14 (2001), 419-453, at 424.

For a recent balance sheet, see E. Lo Cascio, 'Il Mediterraneo Romano fra connettività e frammentazione', Studi storici 56 (2015), 277-285.

35 W.V. Harris, 'The Mediterranean and ancient history', in: idem, ed., Rethinking the Mediterranean (Oxford and New York 2005), 1-42.

36 Explored in the case of Greek colonization by I. Malkin, A Small Greek World: Networks in the Ancient Mediterranean (Oxford 2011). 
Another related perspective is offered by globalization theory. ${ }^{37}$ It is used in cultural theory to study increasing interconnectedness and to analyse responses to it. Much discussion has gone into the question of whether the term is applicable to the ancient world, or whether it should be reserved to describe our modern, truly global, world. However, world historians have pointed out that webs of connections occur in all periods of history. There is not an evolutionary movement towards greater connectedness, but there are certain periods and societal configurations in which such connections intensify. ${ }^{38}$ Roman society certainly qualifies as such a configuration. It is interesting to study both the increase in interconnectedness, and the boundaries of the Roman web-they coincide roughly with the boundaries of empire (with important implications for mobility patterns). The cognate concept of glocalization is also useful to analyse the series of adaptive responses at local level. Both globalization and glocalization, however, betray their origins in cultural studies: they focus mainly on cultural interaction rather than on mobility itself.

In all these theories and models, mobility is accorded a central role. In that sense they are very important, as they give a sense of direction to the subject and embed it in a larger theoretical discussion. They help to explain why we should study migration and mobility. At the same time, they simply postulate high levels of mobility, which itself remains unanalysed and implicitly is also sometimes thought to need no analysis. In that sense their usefulness is more limited than it may seem at first sight.

\section{$5 \quad$ Filling the Gaps}

Much work has been done in recent years to fill the gaps. There are many separate studies, sections in monographs, and edited volumes devoted to the subject of mobility. For example, a monograph by David Noy can be seen as the culmination of the epigraphical tradition of the study of foreigners. It offers very useful observations, mainly based on a corpus of inscriptions of foreigners at

37 The best starting point is M. Pitts and M.J. Versluys, eds., Globalisation and the Roman World. World History, Connectivity and Material Culture (Cambridge 2015), explicitly discussing the relationship with connectivity. For its economic aspects, see Lo Cascio 2015 (op. cit. n. 34), 283 .

38 J.R. McNeill and W.H. McNeill, The Human Web. A Bird's Eye View of World History (New York and London 2003) (though the parts about the Roman empire are not particularly illuminating). 
Rome. ${ }^{39}$ Walter Scheidel offered in two articles a quantitative model for migration in the late Republic, arguing that in that period state-organized mobility (i.e. colonization) was the dominant mode of migration. ${ }^{40}$ Paul Erdkamp has put the importance of seasonal labour migration from the countryside to the city high on the agenda. ${ }^{41}$ Saskia Hin in the context of her study of the demography of the Late Republic has emphasized the fluidity in movements between settlements - much mobility, she argues, was of a transient character. ${ }^{42}$ Claire Holleran has studied the openness of the labour market, arguing against easy absorption of migrants. ${ }^{43}$ Elio Lo Cascio, in his critical re-evaluation of the demography of Roman Italy and the population size of Rome, has addressed the problems of applying urban graveyard theory. ${ }^{44}$

Something of the emerging direction of the discussion might be traced on the basis of several edited volumes that have appeared on the subject of migration and mobility. Whereas earlier volumes contain fewer studies that concern the subject proper than one would expect on the basis of the title, a number have since appeared that address migration and mobility directly. ${ }^{45}$

39 Noy 2000, op. cit. (n. 12).

40 W. Scheidel, 'Human mobility in Roman Italy I. the free population', Journal of Roman Studies 104 (2004), 1-26 and 'II: the slave population', Journal of Roman Studies 95 (2005), 64-79.

41 P. Erdkamp, 'Mobility and migration in Italy in the second century B.C.': in L. de Ligt and S. Northwood, eds., People, Land, and Politics: Demographic Developments and the Transformation of Roman Italy 300 B.C.-A.D. 14 (Leiden 2008), 417-450, with a follow-up in 'Seasonal labour and rural-urban mobility in Roman Italy', in L. de Ligt and L.E. Tacoma, eds., Migration and Mobility in the Early Roman Empire (Leiden 2016), 33-49.

42 S. Hin, The Demography of Roman Italy. Population Dynamics in an Ancient Conquest Society, $201 \mathrm{BCE}-14 \mathrm{CE}$ (Cambridge 2013).

43 C. Holleran, 'Migration and the urban economy of Rome', in C. Holleran and A. Pudsey, eds., Demography and the Graeco-Roman World (Cambridge 2011), 155-180. Inter alia in E. Lo Cascio, 'La popolazione', in E. Lo Cascio, ed., Roma imperiale: una metropoli antica (Rome 2000) 17-69.

45 It is impossible to do justice to the proliferation of studies. Other volumes include M. Sordi, ed., Emigrazione e immigrazione nel mondo antico (Milan 1994); M. Sordi, ed., Coercizione e mobilità umana nel mondo antico (Milan 1995); F. Marco Simon, F. Pina Polo and J. Remesal Rodriguez, eds., Vivir en tierra extraña. Emigración e integración cultural en el mundo antiguo (Barcelona 2004); M.G. Angeli Bertinelli and A. Donati, eds., Il cittadino, lo straniero, il barbaro, fra integrazione ed emarginazione nell'antichità (Atti del I incontro internazionale di Storia Antica, Genova 2003) (Rome 2005); M.G.A. Bertinelli and A. Donati, eds., Le vie della storia. Migrazioni di popoli, viaggi di individui, circolazione di idee nel Mediterraneo antico (Atti del II incontro internazionale di Storia Antica, Genova 2004) (Rome 2006); E. Olshausen and H. Sonnabend, eds., 'Troianer sind wir gewesen.' 
An important volume is Roman diasporas published in 2010, produced by a number of scholars involved in isotopic research. ${ }^{46}$ One significant element of the volume is that it attempts to offer an integrated approach of various types of sources, textual and material. It combines analysis of epigraphy with that of isotopic evidence from skeletons and grave goods. As the title suggests, the concept of diaspora plays an important role in the volume. Migrants are primarily regarded as individuals who bridge the gap between homeland and new country. Given its focus on concepts of diaspora, the contributors not only aim to establish patterns of migration and mobility, but also analyse the way migrants articulated their ethnic identity.

An impressive series of studies has been produced as part of a large research project by Claudia Moatti called 'La mobilité des personnes en Méditerranée de l'Antiquité à l'époque moderne'. 47 The studies share two major characteristics. Firstly, they offer a new institutional approach to the legal evidence, which is read as giving insight into questions of how migration and mobility were conceptualised, how migrants were categorized, and how migration generated documentation that was used to identify them. Secondly, the project engages explicitly in comparative history. The comparative method is important to show how in different pre-modern societies similar issues occurred, but could be solved along different lines. The importance of comparative research is in itself well accepted among ancient historians, but it is not often practised. It brings nuance to an otherwise undifferentiated past of pre-modern migration.

Another recent collection of articles is contained in a volume edited by Luuk de Ligt and Laurens E. Tacoma. ${ }^{48}$ It finds its origin in a research project about the relation between urbanisation, labour and migration in the

Migrationen in der antiken Welt. Stuttgarter Kolloquium zur Historischen Geographie des Altertums, 82002 (Stuttgart 2006); E. Olshausen and V. Sauer, eds, Mobilität in den Kulturen der antiken Mittelmeerwelt. Stuttgarter Kolloquium zur Historischen Geographie des Altertums 11, 2011. Geographica Historica 31 (Stuttgart 2014).

46 H. Eckardt, ed., Roman Diasporas. Archaeological Approaches to Mobility and Diversity in the Roman Empire. Journal of Roman Archaeology Suppl. 78, (Portsmouth 2010).

47 C. Moatti, ed., La mobilité des personnes en Méditerranée de l'antiquité à l'époque moderne: procédures de contrôle et documents d'identification (Rome 2004); C. Moatti and W. Kaiser, eds., Gens de passage en Méditerranée de l'Antiquité à l'époque moderne: procédures de contrôle et d'identification (Paris 2007); C. Moatti, W. Kaiser et Chr. Pébarthe, eds., Le monde de l'itinérance en Méditerranée, de l'Antiquité à l'époque moderne. Procédures de contrôle et d'identification (Bordeaux 2009).

48 L. de Ligt and L.E. Tacoma, eds., Migration and Mobility in the Early Roman Empire (Leiden 2016). 
Principate. As its publication in a series on global migration history testifies, it aims to bring Roman migration history to the attention of migration historians of other periods. This is also visible in its focus on socio-economic and demographic aspects of migration; issues of acculturation and integration are (deliberately) left aside. In many papers labour migration is discussed, and urban graveyard theory plays a large role, though it is treated with varying degrees of acceptance. Underlying the volume is the argument that the distinction between forced, state-organized and voluntary migration is important for analytical purposes, but that the three forms merit being studied together, as they impinged on each other.

One at present still unpublished project also deserves a mention. A new volume edited by Andrea Zerbini and Justin Yoo will provide a diachronic overview of migration and mobility in the Near East. ${ }^{49}$ One of the aims is to redress the balance in geographical coverage: studies of the western Latin part of the empire tend to dominate the discussion. The coverage of a more restricted region over a much longer timeframe creates the possibility to evaluate changes over time with more precision. The volume also aims to integrate the archaeological material into the discussion, while in addition the spatiality of migration is emphasized: mapping mobility is one of its major concerns.

The differences between these approaches indicate that there is as to yet no proper framework for writing Roman migration. Even the question if such a framework is needed is debated, though this brief overview has hopefully made clear how much progress can be made on that front. Perhaps, even, in time the differences between the volumes will seem negligible, and there is indeed some overlap between the volumes, if only because some authors have contributed to more than one book. The overlap is, in fact, productive. The way forward seems to lie in smaller-scale studies, in studying more limited problems, in using more specific types of sources, in analysing more restricted areas, but not doing this in isolation. The more such studies, the better.

The present volume is created in this vein. The impact of mobility and migration in the Roman Empire is the outcome of a conference of the Impact of Empire network. It should be placed in the context of its previous conferences, which concerned frontiers (Impact 9), integration (Impact 10), and external relations

49 A. Zerbini and J.Yoo, eds., Migration, Diaspora and Identity in the Near East from Antiquity to the Middle Ages (forthcoming). 
(Impact 11).50 Some papers have a clear regional focus, others are empire wide. Although a significant amount of late-antique evidence was also discussed at the conference, most of the papers published here focus on the first two centuries AD, though occasionally later evidence is used as well. The papers show a variety of strategies to deal with the sources, and a variety of methods are employed.

In 'Moving peoples in the early Roman Empire', Greg Woolf applies a worldhistorical approach. His paper forms part of a wider project to delineate the properties of ancient mobility. ${ }^{51}$ Roman historians are used to think in terms of empire building through conquest and the acquisition of territory. However, the formation of early states can also be represented as a history of enclosure. States were initially tiny, and growth meant enclosure and moving people around at will. Taking this into account, it is a noticeable feature that the Roman emperors did not shift populations throughout their empire. Woolf shows how remarkable this is even in the Mediterranean and Near-Eastern contexts that we normally study. Omissions are, of course, always hard to explain, and Woolf adduces a number of possible factors that might be taken into account. Woolf's paper shows how the limitations of the sources can be circumvented. No matter how diligently we may read our sources, the absence of imperial intervention only becomes apparent through comparison with other states.

That peoples were nevertheless deported through other means becomes abundantly clear in another contribution. In 'Invasions, deportations and repopulation: mobility and migration in Thrace, Moesia inferior, and Dacia in the third quarter of the third century AD' Lukas de Blois discusses how invasions of the lower Danube region caused havoc. His research is part of his wider interest in the crisis of the third century. Invading Goths, Heruli, and others led to destruction and depopulation. In structural analyses of migration, war-induced mobility is all too easily forgotten, but certainly in the third century it was a major force. De Blois' paper shows in addition how important

5o O. Hekster and T. Kaizer, eds., Frontiers in the Roman World. Proceedings of the ninth workshop of the international network impact of empire (Durham, 16-19 April 2009) (Leiden 2011). G. de Kleijn and S. Benoist, eds., Integration in Rome and in the Roman World. Proceedings of the tenth workshop of the international network impact of empire (Lille, June 23-25, 2011) (Leiden 2014). M. Peachin and D. Slootjes (eds.), Rome and the Worlds beyond its Frontiers. Proceedings of the Eleventh Workshop of the International Network Impact of Empire (New York, June 13-16, 2013) (Leiden forthcoming).

$5^{1}$ See G. Woolf, 'Female mobility in the Roman west', in E. Hemelrijk and G. Woolf, eds., Women and the Roman City in the Latin West (Leiden and Boston 2013) 351-368 and 'Movers and stayers', in L. de Ligt and L.E. Tacoma, eds., Migration and Mobility in the Early Roman Empire (Leiden 2016) 438-461. 
the emergence of new source material can be (in this case the publication of a number of new fragments of Dexippus' Scythica) since the evaluation of the impact of the invasions hinges on a precise historical reconstruction of the events.

That crises had consequences not only for the civilian population is shown by Tony Birley. As he explains, given the fixity of the legions at the periphery in the early Principate, when crises occurred men or units had to be transferred. Such transfers could on occasion take an empire-wide character. Two cases of cross-empire movement of high officials are meticulously reconstructed in his paper, mainly on the basis of the epigraphic record. Birley shows not only how high-ranking officers could be moved from one end of the empire to the other in specific circumstances, but also how in their wake some lesser men could be transferred as well. His paper highlights how careful epigraphical and prosopographical reconstruction can illuminate broader patterns of movement.

A complement to the war-time mobility of military personnel is presented in the paper by Peter Herz. In 'Die Mobilität römischer Soldaten in Friedenszeiten' Herz discusses the rather broad range of activities that soldiers engaged in when they were not fighting. As Herz remarks, apart from its obvious functions in war, the army also represented in peace time a large labour force that could be employed by the state. In the absence of a strict demarcation between civilian and military spheres, Roman emperors took a pragmatic attitude towards this potential labour force and employed soldiers when and where they saw fit. Herz provides an empire-wide survey on the basis of inscriptions and papyri, and uses the individual bits of information to create a typology of various types of peace-time mobility. The accumulated evidence suggests that the army in peace time was astonishingly mobile.

Amidst everything that is known about the ordo senatorius it is remarkable that senatorial mobility has not received the attention it deserves. Werner Eck's 'Ordo senatorius und Mobilität: Auswirkungen und Konsequenzen im Imperium Romanum' makes up for the deficit. Eck not only traces the movement of senators and their families, but also emphasizes its effects on society. His analysis revolves around a number of elements: the well-known changes in the composition of the senate, the requirement that senators had to be physically present in Rome, the laws stipulating that a significant amount of their property had to be located in Italy, the fact that many magistracies entailed stays outside Rome and that their tenure also implied a significant amount of mobility. The sources, mainly but not solely epigraphical, are used to create a balance sheet. Not all of the consequences were positive, Eck emphasizes: for senatorial families, movement to Rome implied loss of influence in the dayto-day politics of the local community they originated from, whereas for the 
local communities the senatorial transfer of wealth to the centre could be a significant drain. Eck emphasizes that newly established aristocratic households in Rome served in their turn as magnets for local communities seeking patronage. Migration fostered further mobility.

The latter element forms a connection to the paper by Elena Torregaray Pagola, whose study 'Diplomatic mobility and persuasion between Rome and the West (I-II AD)' starts from the dual observations that diplomatic efforts in the imperial period were mainly internal rather than by outsiders, and that there was a difference in the frequency with which they occurred between the western and eastern parts of the empire. Torregaray Pagola shows how legationes served to reiterate loyalty, fidelity and adhesion to the princeps. In many cases the embassies had no immediate concrete purpose, but served to establish direct ties with the centre that could be capitalized on at a later stage. In an important aside, she emphasizes that the nature of our documentation is such that it only focuses on the successes. Failed legationes are a rarity in our sources; at the same time, the immense stream of legationes coming from all over the empire must have meant that obtaining access to the emperor or the court cannot have been easy and in itself must already have counted as a success.

What is recorded and what is not is also central to the paper by Laurens Tacoma, which is written as a methodological pendant to his monograph Moving Romans. ${ }^{52}$ In 'Bones, stones, and Monica. Isola Sacra revisited', he juxtaposes three source types: isotopes, inscriptions, and the migration narrative of Augustine's Confessiones. Each source holds great potential for the study of migration, but the problem is that each tells a rather different story. Isotopes suggest a very significant presence of migrants at Ostia/Portus, epitaphs give precise information about their whereabouts but are few in number, whereas the Confessiones suggest how small families may have moved in patterns of step-wise mobility. His paper is presented as a warning against integrating the sources too hastily into a single migration narrative, and also as a warning against over-reliance on epigraphical evidence alone.

In 'Between mobility and connectivity in the ancient Mediterranean: coastskirting travellers in the southern Levant', Gill Gambash explores the limitations of Horden and Purcell's concept of connectivity. Connectivity is not the same as actual human mobility, Gambash argues, and if Horden and Purcell's cabotage was as important for trade in the Mediterranean as they say, this must have important implications for passenger transport as well. Gambash's reading of the literary sources and the archaeological evidence from shipwrecks 
leads to a nuanced account of the possibilities and obstacles: most travel will have consisted of broken journeys, in small ships. Yet shipping routes were also remarkably resilient, in the Southern Levant continuing well into the early Islamic period.

Shipwrecks-imagined or real-also play a large role in the study by Margherita Carucci. It is well known that migration and mobility are gendered: male and female patterns of mobility, and the roles that are ascribed to them, may differ significantly. In 'The dangers of female mobility in Roman imperial times', Carucci explores the tension between two strong ideological concepts. On the one hand there was a rigid division of gender roles in which the female role was firmly positioned within the household, while on the other hand concordia between wife and husband structured their marriages. When husbands moved out of the house to serve as magistrates or generals, a conflict arose between the two concepts. It found its most literal expression in the concrete question of whether wives should follow their husbands abroad. On the basis of a large number of passages from Latin literature, Carucci shows how the tension was explored in literature, while at the same time pointing out that the female perspective is almost entirely lacking in such writings.

Starting from the famous papyrus in which the emperor expelled the Egyptians from Alexandria, Elena Koestner explores the concept of ethnic colonies. In 'The linouphoi of P. Giss. 40 ii revisited: applying the sociological concept of ethnic colonies to Alexandria's linen-weavers', she argues that the Egyptians who migrated to Alexandria from the chora as labourers can be regarded as an ethnic community. This community functioned as a gateway for migrants into Alexandrian society, yet at the same time because of its visibility it could also be easily targeted in times of crisis, with the result that all Egyptians were expelled from the city.

'Coloni et incolae, vingt ans après. Mobilité et identité sociales et juridiques dans le monde romain occidental' by Stéphane Benoist starts from the observation that the perspective in the study of mobility has changed in response to modern concerns. Where 25 years ago the aim was to define imperialism and empire, nowadays modern refugee streams, problems of integration, and their consequences for societal cohesion are at the forefront of the concerns. Benoist focuses on those documents that provide information about terminology and the legal status of outsiders in the Roman host societies, mainly epigraphical ones. They show that Roman categorisations were far from stable; the meaning of incolae and coloni shifted over time. This dynamism forms a good starting point for the study of heterogeneity and integration.

Some of Benoist's themes are picked up in the survey by Claudia Moatti. As stated above, her paper forms part of a much wider research project that is based on two principles: comparative research and the integration of law and 
politics. Taking migration as a social process, she discusses how foreigners were categorized and at what level migration was subject to control. Moatti moves away from the notion that state intervention was limited but rather focuses on its role in channelling migration. She shows how the rich tapestry of legal evidence can not only be employed to determine formal state policy, but also or even primarily gives insight into general attitudes and mental categories.

\section{7}

\section{Creating Empire}

Although a new framework is still in the making, it is clear how far we are removed from Paul the Deacon's eighth-century perspective on Roman migration. The causation of migration is nowadays usually perceived quite differently from that proposed by Paul. We are wary of determinism, and perceive migration easier in pull terms than push terms (or try to avoid such terminology altogether). We tend to regard migration and mobility primarily as individual movement rather than that of collectives. We also try to avoid value judgements, and do not automatically see migration as a negative force.

We are inclined to think in multiple types of mobility rather than two types of migration. Various types of mobility are discussed in the papers. Collective deportations are discussed by de Blois and by Woolf, diplomatic mobility by Torregaray, and senatorial mobility by Eck. Cross-empire mobility of viri militares is addressed by Birley, peace-time military mobility by Herz. Marital mobility (of women accompanying their husbands) is covered by Carucci and Tacoma. Trade underlies much of the discussion of Gambash; temporary labour mobility is discussed by Koestner. A significant part of the mobility spectrum is covered, of varying duration and varying degrees of permanency.

These types of mobility impinged on each other. So, as Eck points out, senatorial mobility consisted of two separate movements: first the permanent migration of prospective senators to Rome, then their subsequent movement away from Rome as administrators for shorter stints. That Roman mobility patterns were extremely complex and interconnected might seem all too obvious, but its diversity is certainly a fundamental trait to keep in mind. For the modern period, a recent encyclopaedia lists over 200 forms of migration, ${ }^{53}$ and it would be surprising indeed if in the Roman period migration were monolithic.

Obviously, people, goods and ideas spread, though not always simultaneously. It also seems likely that in the Roman period its scale was much larger than in previous and later periods. There cannot be any real doubt that the shift 
in geographical horizons also entailed a shift in mental ones. One may with justification emphasize that women were socially caged, ${ }^{54}$ but the sources also suggest that even their geographical horizons widened in the Roman period.

Such behaviour had economic consequences. These consequences are in the case of senatorial mobility explicitly addressed by Werner Eck: the concentration of wealth in Italy and the corresponding depletion of local funds. Elena Torregaray Pagola mentions the costs of the legationes, and of course some legationes were used to bring local economic problems to the attention of the emperor. The type of rural-urban labour migration discussed by Koestner from the Egyptian chora to Alexandria will have generated streams of wealth from the centre to the periphery.

As the diaspora theory discussed by Moatti suggests, migrants acted as intermediaries between sending and receiving communities. ${ }^{55}$ Some did so in a literal sense. The case of the ambassadors is telling; apart from concrete benefits, they participated in a form of social ritual that tied communities to the centre. If we assume that many migrants remained in close contact with their home communities, such cultural brokerage became all the more important in creating a sense of coherence.

In that sense people created the Roman empire with their feet. Yet what did this empire look like? Migration streams are often conceptualised as a network. By moving around, people created a web of relationships. Obviously the density of the network intensified under Roman rule, and this was without doubt a very important development. Nevertheless, it remains remarkable that on the one hand people could travel freely from one end of the empire to the other, but, as Birley's paper shows, even within the army the attested cases remain exceptional. Rome's centrality in the migration network was undoubted, but for the rest there were regional patterns of zoning. Following Gambash' analysis of broken voyages, perhaps should we speak of a fractured connectivity in the Roman world?

Leiden-Rome, June 2016

\footnotetext{
54 Woolf 2013, op. cit. (n. 51).

55 T.T. Terpstra, Trading Communities in the Roman World: a Micro-economic and Institutional Perspective (Leiden 2013).
} 


\title{
Moving Peoples in the Early Roman Empire ${ }^{1}$
}

\author{
Greg Woolf
}

\section{$1 \quad$ Six Thousand Years of Enclosure}

The opening pages of James C. Scott's The Art of Not Being Governed offer a global account of the political economy and ecology of early states. The first states, for Scott, were miniscule authoritarian regimes nestled on arable plains and plateaux and surrounded by vast ungoverned peripheries of mountain, marshland, swamp, steppe and desert. Around them peripheral populations were both natural trading partners - because the ecologies of their respective homes were so different - and a constant threat. Peripheral populations posed a double threat in fact since they not only periodically raided the plains, but also represented an alternative, freer way of life, an object lesson in "the art of not being governed".

For Scott, whose expertise is in the societies of South East Asia, the story of the last six thousand years has been one of enclosure. States have strived to tame their peripheral 'barbarians', subjecting them to taxes and the levy, to slavery and government. Subjected peoples were put to work to increase the agricultural surpluses on which states depended and to build the monuments that now constitute the principal record of their efforts. That history of enclosure has been a discontinuous one, since in the remote past states often collapsed, their subject populations melting away into the forests and mountains until the next episode of state building. Only in the last few centuries has the option of avoiding the state altogether more or less disappeared. But for most of history there has been a range of social options. ${ }^{2}$

To historians of the ancient Mediterranean world the proposition that ancient state building was all about enclosing human populations and putting them to work is unfamiliar. When we write about expansion we usually mean the acquisition of territory, and we often treat its inhabitants as encumbrances

1 I am grateful to those who heard and responded to the presentation in Rome, to this volume's editors and also to Myles Lavan and Francisco Pina Polo for providing me with additional material and comment.

2 J.C. Scott, The Art of Not being Governed. An Anarchist History of Upland Southeast Asia (New Haven 2009). 
that came with it. Like nineteenth- and twentieth-century empire builders we think of expansion in terms of the conquest of new land, as a forced transfer of property. Slogans such as 'the sun never sets on the Union flag' presupposed a geographical and territorial notion of empire. Mostly we apply the same idiom to the ancient world, channelling some (but not all) of the ways that ancient sources described the process. ${ }^{3}$ Caesar, we repeat, conquered the whole of Gaul, and was the first to take Roman troops across the Channel and the Rhine.

Scott invites us to think instead of Caesar as taking control of the Gaulish tribes, harnessing the warrior energies of some, and subjecting the rest to regimes of labour management that through one route or another enriched the Roman people. John Richardson showed twenty five years ago that Romans came rather late to thinking of their power in terms of its territorial extent: imperium acquires a geographical sense only at the very end of the Republican period. Other senses of the word, such as 'rule', 'dominion' and 'command' persist well into the Principate. Myles Lavan has demonstrated more recently that even during the first two centuries AD, the language that Romans applied to their subjects derived mainly from domestic relations of subjection, rather than from their spatial marginalization. ${ }^{4}$ All the same it is difficult for us to get out of the habit of thinking of ancient states as territorially circumscribed jurisdictions - as rather like modern sovereign states in fact—despite the fact that many ancient authors wrote in terms of peoples rather than polities or spaces. Ancient ethnicities were constructed on the basis of fictive kinship, on myths of common descent, on a shared history and sometimes shared language, worship and customs: residence was rarely stressed. ${ }^{5}$ Imperium populi Romani did not describe a bounded political entity exercising jurisdiction over a portion of the globe, so much as the domination of one people over a number of subject peoples. Triumphal rhetoric and monuments typically

3 For that strand of ancient thought see C. Nicolet, L'Inventaire du monde. Géographie et politique aux origines de l'Empire Romain (Paris 1988).

4 J.S. Richardson, The Language of Empire. Rome and the Idea of Empire from the Third Century $B C$ to the Second Century AD (Cambridge 2008); idem, 'Imperium Romanum. Empire and the language of power', Journal of Roman Studies 81 (1991), 1-9; M. Lavan, Slaves to Rome. Paradigms of Empire in Roman Culture (Cambridge 2013).

5 Inter alia by J.M. Hall, Hellenicity. Between Ethnicity and Culture (Chicago 2002); E. Dench, Romulus' Asylum. Roman Identities from the Age of Alexander to the Age of Hadrian (Oxford 2005); T. Derks and N. Roymans, eds., Ethnic Constructs in Antiquity. The Role of Power and Tradition (Amsterdam 2009); N. Roymans, Ethnic Identity and Imperial Power. The Batavians in the Roman Empire (Amsterdam 2004); G. Woolf, Tales of the Barbarians. Ethnography and Empire in the Roman West (Malden, MA and Oxford 2011); S. Mitchell and G. Greatrex, eds., Ethnicity and Culture in Late Antiquity (London 2000); T. Whitmarsh, ed., Local Knowledge and Microidentities in the Imperial Greek World (Cambridge 2010). 
celebrated the conquest of peoples: the fasti triumphales mostly refer to defeated kings or populations. When attention is focused on places or citiesas on the Sebasteion of Aphrodisias or the Temple of Hadrian in Rome-provinces and cities are typically personified, creating what Bert Smith has called simulacra gentium. ${ }^{6}$

Despite these considerations, it turns out to be quite difficult to write about the Roman empire as one chapter in a global history of enclosure. Our default modes of analysis depend either on legalistic/constitutional concepts inherited from the nineteenth century, or else on a political economy paradigm which is good at charting the extraction and redistribution of material resources, but poor at describing Roman biopower. One possibility is that historians of western antiquity have simply become used to using a different set of conceptual frameworks to describe and analyse state-building and the origins of empires than their counterparts who work on eastern Asia. But if that were the case then with a little ingenuity we could rephrase our questions in their terms.

But the problem is more fundamental than that. It is in fact rather difficult to find examples of Roman emperors transplanting entire populations from one part of their realm to another, or putting subject populations to work on great capital projects in the way that other empires did. Romans could certainly imagine power exercised in that way, indeed it was a part of the stereotype of tyranny that they inherited from Greek historiography. The tradition of how 'La Grande Roma dei Tarquinii' was built fits the pattern happily. ${ }^{7}$ Yet Rome's emperors seem to have refrained from moving their subjects about in this way. This paper asks why this was the case.

Just how unusual Rome was in this respect emerges from consideration of some other early empires. The Qin Emperor of China reputedly mobilized huge numbers to work on the Great Wall, to construct the Ling canal to link the Pearl and Yangtze River systems, to build roads, royal palaces and famously his mausoleum at Lishan. The terracotta army, which comprises many more

6 R.R.R Smith, 'Simulacra gentium: The ethne from the Sebasteion at Aphrodisias', Journal of Roman Studies 78 (1988), 50-77; M. Sapelli, ed., Provinciae fideles. Il fregio del tempio di Adriano in Campo Marzio (Milan 1999); R.M. Schneider, Bunte Barbaren. Orientalenstatuen aus farbigem Marmor in der römischen Repräsentationskunst (Worms 1986).

7 M. Cristofani, ed., La grande Roma dei Tarquini. Roma, Palazzo delle esposizioni, 12 giugno-3o settembre 199o. Catalogo della mostra (Rome 1990). 
professions than the military alone, is in some sense a monument to the vast and varied human capital he was able to amass and deploy. As so often, early imperial habits emerged from an intensification of some aspects of pre-imperial systems. The kingdom of Qin already owed some of its wealth to the settling of convicts in Sichuan to exploit its mineral and agricultural resources. ${ }^{8}$ Later dynasties - and arguably Communist China too-continued the tradition of carrying out massive public works by obliging its subjects to work on them.

China was not an isolated case. At least some of the monumental building in Pharaonic Egypt depended on labour extracted from subject populations. The so-called workers' town at Giza for those labouring on the construction of the pyramids was likely filled through forced population transfer. Further afield the Inka derived some of their wealth from organized programmes of settlement, in effect internal colonization projects: it has been estimated that several million people were resettled during the centuries of Inka rule. ${ }^{9}$ The Mitma system transplanted populations of loyal Quechua speakers into conquered territory, while rebellious populations were deported from their homes. Census systems and officials from the central government kept track of the Inka's subjects and from these we can see some mitmaqkuna were designated miners or weavers.

In other instances, forced population movements have been inferred from other evidence. The city of Teotihuacan 30 miles northeast of what is now Mexico city was the site of major monumental building during the second and third centuries AD and remained in occupation until the middle of the sixth century. The peak population is estimated at 125,000. Almost nothing is known for sure of its history, but its exceptional scale, its intricately planned systems, its tight zoning by occupation and ethnic origin and the fact that it stood more or less alone in a rural landscape rather than at the top of a hierarchy of cities all strongly suggest that it was created by an act of political will backed by compulsory movements of population. ${ }^{10}$ Similar arguments have been advanced to account for other prehistoric cases, among them the Mound Builders of the

8 R.D.S. Yates, 'Cosmos, central authority and communities in the early Chinese Empire', in S.E. Alcock et al., eds., Empires. Perspectives from Archaeology and History (New York and Cambridge 2001) $35^{-1}-368$.

9 T. D'Altroy, 'Politics, resources and blood in the Inka Empire', in S.E. Alcock et al., eds., Empires. Perspectives from Archaeology and History (New York and Cambridge 2001), 201-226.

10 L.R. Manzanilla, 'The basin of Mexico', in C. Renfrew and P. Bahn, eds., The Cambridge World Prehistory (New York 2014), 986-1104. 
Mississipi and the great hillforts of late prehistoric Europe. Cities and large monumental complexes do sometimes emerge from more gradual processes of settlement growth and hierarchization. But it is also quite common for societies to undergo a sort of phase transition, characterised by a rapid shift from dispersed villages to a smaller number of nucleated settlements. Sometimes despotic rulers have been considered the prime movers in these ventures. On other occasions, as Norman Yoffee has argued, sudden changes were themselves probably a stimulus for state building. ${ }^{11}$

Some of these massive projects - and we could add the construction of irrigation systems, the maintenance of transport infrastructure and intensifications of agricultural production for the benefit of imperial courts and armies - could be achieved by corvée labour, by imposing obligations on populations where they already lived, or by temporary relocations. But it is also clear that many imperial regimes thought nothing of permanently moving populations from one location to another. Rome, apparently, did this very rarely. This is all the more surprising since mass deportation was employed by some powers of which Romans were very well aware: I refer to the very common use of deportation as an instrument of control by Near Eastern monarchies.

\section{3} Moving Peoples in the Ancient Near East

Moving peoples — and boasting about it - became part of the idiom of royal power during the Bronze Age. ${ }^{12}$ The first instances I have found occur in Hittite monumental inscriptions and relate to the capture of entire peoples and their relocation to places where they were put to work on behalf of the crown. It is quite unlikely the Hittites originated the practice. ${ }^{13}$ Forced relocation became a key instrument of imperial policy during the Assyrian New Kingdom. ${ }^{14}$ The history of Assyrian deportations is reconstructed almost entirely from monumental royal inscriptions, and some hyperbole has been suspected. But even if the claims of between 4 and 5 million deportees are treated with scepticism by

11 N. Yoffee, Myths of the Archaic State. Evolution of the Earliest Cities, States, and Civilizations (Cambridge and New York 2005).

12 K. Radner, 'Mass deportation: the Assyrian resettlement policy', University College London 2012, http://www.ucl.ac.uk/sargon/essentials/governors/massdeportation/ (last consulted December 2015).

13 T. Bryce, 'Anatolian states', in P.F. Bang and W. Scheidel, eds., The Oxford Handbook of the State in the Ancient Near East and Mediterranean (New York and Oxford 2013), 161-179.

14 B. Oded, Mass Deportations and Deportees in the Neo-Assyrian Empire (Wiesbaden 1979). 
some experts, the scale of the movement of people is undoubted. More than 150 deportations are attested. ${ }^{15}$ Deportation was used as a punishment for rebels. It was probably also used (very much as James C. Scott argued for South East Asia) to control semi-nomadic populations of Arameans and Chaldeans on the margins of the Land of Assur, the Assyrian homeland that was conceptually distinct from the subjugated provinces. ${ }^{16}$ The aim seems not simply to have been to punish enemies nor even to break the connections of troublesome subjects with their places of origin. One component of the rhetoric was a simple demonstration of the power of Assyria's rulers. So Assurbanipal, celebrating his wars against the Arabs:

People of both sexes, donkeys, camels, cattle and small cattle without number I brought to Assyria. The area of my whole land in its entirety they filled as far as it stretches. Camels I shared out like small cattle to the people of Assyria. ${ }^{17}$

Royal inscriptions did not represent deportation simply as another weapon of terror, alongside the totals of the dead they celebrated or the gruesome imagery of slaughter on the reliefs that accompany some inscriptions. Deportation was also represented as an opportunity, even a magnanimous gesture that made the deportees favoured subjects. ${ }^{18}$ In an idiom that seems very strange to Roman historians, Assyrian rulers sometimes present themselves as gardeners, exercising a kind of benign stewardship over the land and its peoples, transplanting and replanting populations with an eye to the prosperity of the land of Assur as a whole. ${ }^{19}$ More than 80 per cent of deportations seem to have brought peripheral populations into northern Assyria and there are clear links with the grandiose royal city building projects at Assur, Nimrud, Khorsabad and Nineveh. ${ }^{20}$ Deportees helped build the cities, and many were put to work farming previously unproductive lands around them. Others presumably formed part of the populations of the largest cities. The walls of Nineveh

\footnotetext{
15 Ibidem.

16 J.N. Postgate, 'The land of Assur and the yoke of Assur', World Archaeology 23.3 (1992), 247-263.

17 VAT 5660+ cited by A. Kuhrt, The Ancient Near East, c. 3000-330 BC II (London 1995), 519.

18 W.R. Gallagher, 'Assyrian deportation propaganda', State Archives of Assyria Bulletin 8 (1994), 57-65.

19 Radner 2012, op. cit. (n. 12).

20 P.R. Bedford, 'The Neo-Assyrian Empire', in I. Morris and W. Scheidel, eds., The Dynamics of Ancient Empires. State Power from Assyria to Byzantium, Oxford Studies in Early Empires (New York 2009), 30-65.
} 
enclosed around 700 ha. It is difficult to believe its inhabitants had not been assembled from a wide area.

There is a striking difference here from the way the expansion of the City of Rome is usually understood, as chaotic, organic and unplanned growth, a process that posed problems for Rome's rulers and was certainly not orchestrated by them. Our most common point of comparison, since the work of Keith Hopkins, has been with the growth of London in the eighteenth century, a process of growth that was certainly not planned. ${ }^{21}$ Hopkins saw Roman urban growth as an indirect and unintended effect of Roman conquest: it was the expenditure of booty in the city and the displacement of peasants around it by slaves captured in war, that led to urban growth. Morley's view was very similar: empire was the only thing that made a city of the size of Rome sustainable. As in the case of early modern London the authorities responded to processes already underway: those responses included censorial building and grain doles during the Republic, greater regulation and a rudimentary urban administration under the Principate. Some have suggested that some of these expedients-among them aqueduct building, measures against food crisis, better protection against flood and fires - not only made the megalopolis sustainable, but also attracted new migrants. It is difficult to assess such claims. Walter Scheidel has recently argued that many migrants came to Rome in chains. ${ }^{22}$ Even then forced immigration tends to be treated as a solution to a labour shortage (one caused by the so-called urban graveyard effect). The process was organized by would-be slave owners rather than the senate or emperor (although these groups naturally overlapped). Near Eastern megalopoleis, by contrast, and the deportations that filled them, are represented as projects conceived, directed and realized by kings.

The best evidence for mass population movements in the Neo-Assyrian Empire is from the eighth and seventh centuries BC, from the reigns of Tiglath-Pileser III, Shalmaneser v, Sargon II, Sennacherib, Esarhaddon and Assurbanipal. How successful mass deportations were either in increasing

21 K. Hopkins, 'Taxes and trade in the Roman empire, 200 BC-AD 200', Journal of Roman Studies 70 (1980), 101-125; idem, Conquerors and Slaves. Sociological Studies in Roman History I (Cambridge 1978); idem, 'Economic growth and towns in Classical Antiquity', in Ph. Abrams and E.A. Wrigley, eds., Towns in Societies. Essays in Economic History and Historical Sociology (Cambridge 1978), 35-77; idem, 'Introduction', in P. Garnsey, K. Hopkins and C.R. Whittaker, eds., Trade in the Ancient Economy (London 1983), ix-xxv; N. Morley, Metropolis and Hinterland. The City of Rome and the Italian Economy 200 B.C.A.D. 200 (Cambridge 1996).

22 W. Scheidel, 'Human mobility in Roman Italy II: the slave population', Journal of Roman Studies 95 (2005) 64-79. 
the productivity of northern Assyria or in strengthening the state is not clear. But the practice of deportation survived the fall of Assyria in 612 вс. The Babylonian Captivity of the Jews in 586 BC is the only episode documented from the point of view of the deportees. The symbolic place the Exile occupies in a long tradition of displacements from the Land of Israel, second only to the captivity in Egypt, has obscured some important features. ${ }^{23}$ First of all this was not the first occasion on which an attempt was made to bring the population of Jerusalem into Mesopotamia. Gallagher quotes from Kings II the speech made by an Assyrian general besieging the city in the reign of Hezekiah.

... for thus says the king of Assyria: 'Make peace with me and come forth to me and eat, each from his vine and each from his fig tree and drink, each from the water of his well, -when I come and take you to a land like your land, a land of grain and wine, a land of bread and vineyards, a land of olive oil and honey, and you will live and not die, but do not listen to Hezekiah because he is inciting you.'24

The most obvious inference is that the population of Israel was regarded as an asset to be acquired. This speech is reasonably understood as propaganda, but it does not follow that some deportees did not at least eventually reconcile themselves to their new homes. Once again the Jewish experience is revealing. While the biblical narrative focuses on the return and rebuilding of Jerusalem under Nehemiah, under the patronage of a god-fearing Persian monarch, it is also well known that many Jews remained in Babylonia. The Book of Tobit begins by describing how Tobit had been deported from Galilee and resettled in Nineveh during the reign of the Assyrian king Shalmaneser, and goes on to describe his and his son Tobias' travels back and forth to their relative in Ecbatana in Media. The book was probably composed in the Hellenistic period, but there is perhaps no reason to distrust the picture it assumes of a scattered Israel under the last Assyrian Monarchs. Under the Achaemenid Empire we find Jewish settlement even more widespread. From the end of the fifth century ВС an archive of documents in Aramaic attests the presence of a Jewish military colony in Egypt: when it arrived is not certain but an Achaemenid

23 On the tendency of Jewish historiography to seek cyclical patterns in history by equating for example Babylon and Rome, see N.R.M. de Lange, 'Jewish attitudes to the Roman empire', in P. Garnsey and C.R. Whittaker, eds., Imperialism in the Ancient World (Cambridge 1978), 255-281.

24 II Kings 18: 31-2. Gallagher 1994, op. cit. (n. 18), 4. 
date is perhaps most likely, although the letters refer to a Jewish Temple at Elephantine in the sixth century вс. ${ }^{25}$

Achaemenid rulers made less of deportation in their imperial rhetoric. The Cyrus Cylinder, made in the 530s BC, declared that on his accession Cyrus had returned all the captive gods and their peoples to their own lands on the instructions of Marduk, the High God of Babylon. All the same there is ample evidence of population displacements. ${ }^{26}$ The Encyclopaedia Iranica notes Cambyses transplanting 6000 Egyptians to Susiana, Darius I moving Barcaeans from north Africa to Bactria and Paeonians from Thrace to Anatolia, to say nothing of many displaced Greeks and Phoenicians. Recipients of rations listed on the Persepolis Fortification Tablets show labourers were still routinely identified by their ethnic, as are many individuals named in documents from Late Period and Ptolemaic Egypt. Achaemenid successor states continued to settle subjects in distant locations. According to Pliny the Elder those Romans captured by the Parthians at Carrhae-which Plutarch gives as 10,000 in number-were resettled in Margiana. ${ }^{27}$ The much later foundation of Ctesiphon by Chosroes I in the sixth century AD was described as a city for those he had captured in his campaigns against the Byzantines. Perhaps we should also include here the settlements of Macedonian and Thracian katoikoi in the core territories of the Seleukid kingdom, and the Greek poleis created all over the Hellenistic world by Alexander and his successors. ${ }^{28}$ The foundation of Alexandria in Egypt must have resembled the great city building projects of Assyrian and Iranian kings much more than the incremental organic growth posited for imperial Athens and Rome. ${ }^{29}$

25 J.M. Modrzejewski, The Jews of Egypt. From Rameses II to the emperor Hadrian (Edinburgh 1995), 21-44; B. Porten, The Elephantine Papyri in English. Three Millennia of Cross-cultural Continuity and Change (Leiden 1996).

26 A. Shahpur Shahbazi, 'Deportations. i. in the Achaemenid period', Encyclopaedia Iranica vir fasc. 3 (1994), 297-312; available online at http://www.iranicaonline.org/articles/ deportations\#ptı (last consulted December 2015).

27 Plut. Crass. 31; Plin. NH. 6.18 (47).

28 Seleukid military colonies: B. Bar Kohkva, The Seleucid Army. Organization and Tactics in the Great Campaigns (Cambridge 1976) 20-48.

29 The manner (and even the chronology) of the foundation of Alexandria in Egypt is very unclear. W. Scheidel, 'Creating a metropolis: a comparative demographic perspective', in W.V. Harris and G. Ruffini, eds., Ancient Alexandria between Egypt and Greece (Leiden 2004), 1-31 poses the problem neatly and suggests some possible answers. 
Had Roman emperors wished to move their subjects around there were other models they might have followed besides those provided by the monarchies of the Ancient Near East. Within the Mediterranean world there were already traditions of synoecism and colonization that might been developed further. Yet after the reign of Augustus, there were apparently few attempts to build on these traditions as a means of deploying the empire's human capital where it might best serve imperial ambitions.

Forced synoecisms appeared for the first time around the middle of the last millennium BC. Up until that point urban systems seem to have formed around the Mediterranean in a less planned and more organic way, a process closely connected with agricultural expansion, demographic growth and the connecting up of Iron Age communities around the inland sea. Cities formed first as nodes at key points of connection between long-distance exchange partners. What used to be termed Greek, Phoenician and Etruscan colonies now often seem like collaborative projects between various groups of incomers and local chieftains. Similar dynamics probably lay behind what are traditionally seen as indigenous paths to urbanism in Spain and southern Gaul, Sicily and central Italy. The cities that emerged from these collaborations were typically very small indeed by the standards of the ancient Near East, their populations numbering a few thousand individuals in most cases. Even under the Principate only one in four of the two thousand odd cities in the empire had more than 5,00o inhabitants. Gentle hierarchies and loose networks emerged naturally from traffic between these micro-cities. ${ }^{30}$

From the fourth century $\mathrm{BC}$ autocrats of different kinds began to intervene in these urban networks. Among these interventions were forced mergers of cities engineered by 'tyrants' in Sicily; attempts to obliterate ancient cities (e.g. Mitylene, nearly, in the fifth century and Thebes in the fourth, then Carthage and Corinth in the second century BC at the hands of Rome); the creation of royal centres like Cassandreia and Demetrias; the refoundation of ancient cities such as Ephesos by Hellenistic kings; and the foundation of new cities within conquered Persian territory by Alexander and his successors. What made this possible was the growth of some polities at the expense of others. But it is less clear why meddling with the urban network was thought desirable or sensible. One contributory factor may have been the reification of the polis as a political ideal. The polis appears in fifth century historiography and

30 Some suggestive ideas are contained in I. Malkin, A Small Greek World. Networks in the Ancient Mediterranean (New York 2011). 
fourth century philosophy as both an idealtype and also as a set of normative institutions. The idea that founding urban centres was the act of political creation par excellence presumes an identification of city and state. Ian Morris has argued that state formation came relatively late to the Greek world-centuries after urbanism in fact-and therefore that the city-state proper emerged only in the sixth and fifth centuries BC. ${ }^{31}$ Maybe before this point reconfiguring the political landscape did not necessarily entail restructuring the urban network. Alternatively, perhaps it was simply the growing resources of kings and other autocrats that made forced synoecisms and dispersals more common. The foundations of Megalopolis in 371 BC and of Messene in 369 BC show that monarchs were not the only engineers of synoecism. But most major cities were created and sustained by kings, tyrants or generals, and most presumably originated in the forced relocations of populations. How consciously city founders drew on Near Eastern precedent is unclear.

Arguably some Republican period colonization represents a variation on this process, the main difference being that decision making was not taken by a monarch, and that a large part of the settlers were apparently volunteers. This second proposition is traditional wisdom but might be questioned. The testimony on mid-Republican colonies suggests frequent failures, many manifested in colonists leaving their new settlements. The involvement of non-citizens in some foundations also raises questions about how far settlers were entirely free to choose. The formation of Roman Italy almost certainly did involve some forced resettlement. ${ }^{32}$

\section{5} How Romans Moved People

It is in contrast to activities of this sort that the apparent reluctance of Roman emperors to move and resettle conquered populations seems unusual. This did not mean that there was no human mobility, nor even that some of it was not indirectly a product of imperial power. But these cases seem different to the kind of relocations common elsewhere.

31 I. Morris, 'The early polis as city and state', in J. Rich and A. Wallace-Hadrill, eds., City and Country in the Ancient World (London 1991), 25-57.

32 F. Pina Polo, 'Deportation, Kolonisation, Migration. Bevölkerungsverschiebungen im republikanischen Italien und Formen der Identitätsbildung', in M. Jehne and R. Pfeilshifter, eds., Herrschaft ohne Integration? Rom und Italien in republikanischer Zeit (Frankfurt 2006), 171-206; J. Pelgrom and T. Stek, eds., Roman Republican Colonization. New Perspectives from Archaeology and Ancient History (Rome 2014). 
First, there is no doubt that many individuals were relocated during this period and some of them against their will. In this category I would include (a) many slaves, (b) some prisoners of war and hostages, and (c) those who in judicial or quasi-judicial manner were sent into exile (if they were of high status) or condemned ad metalla, to the mines, if they were not. Slaves were generally moved not by the state, but by private shippers for sale to private individuals. ${ }^{33}$ Captivi who were neither killed nor ransomed were often sold as slaves rather than retained as a workforce. Caesar's Gallic War makes clear that prisoners were often distributed as part of the booty. Josephus records a group of Jewish prisoners who were despatched to work on Nero's project at the Isthmus of Corinth. ${ }^{34}$ But otherwise there is no sign that prisoners of war were systematically put to work on state building projects. Exiles were numerically almost insignificant, even if their high status makes them highly visible in the historical record. Some were banished from Rome or Rome and Italy. From the reign of Augustus a few were banished to specific locations which they were forbidden to leave. ${ }^{35}$ Condemnation to hard labour existed, but was never practiced on a massive scale, as Rens Tacoma and Miriam Groen-Vallinga have recently confirmed. ${ }^{36}$

Second, the recruitment, deployment and resettlement of soldiers represented a major state intervention in mobility. The first experiments in this direction were rather informal creations such as Gracchuris and Lugdunum Convenarum. Both were apparently cases of peripheral imperialism, that is

33 W.V. Harris, 'Towards a study of the Roman slave trade', in J.H. D'Arms and E.C. Kopff, eds., The Seaborne Commerce of Ancient Rome (Rome 1980), 117-140; idem, 'Demography, geography and the sources of Roman slaves', Journal of Roman Studies 89 (1999), 62-75; W. Scheidel, 'Quantifying the sources of slaves in the early Roman Empire', Journal of Roman Studies 87 (1997), 156-169; J.-M. Lassère, 'La mobilité de population. Migrations individuelles et collectives dans les provinces occidentales du monde romain', in A. Akkeraz et al., eds., L'Africa romana 16. Mobilità delle persone e dei popoli, dinamiche migratorie, emigrazioni e immigrazioni nelle province occidentali dell'Impero romano. Atti del XVI convegno di studio, Rabat, 15-19 dicembre 2004 (Rome 2006), 57-92.

34 J. BJ 3.540.

35 C. Moatti, 'Immigration and cosmopolitanization', in P. Erdkamp, ed., The Cambridge Companion to Ancient Rome (Cambridge 2013), 77-92; S.T. Cohen, 'Augustus, Julia and the development of exile ad insulam,' Classical Quarterly 58.1 (2008), 206-217; M. Vallejo Girvés, J.A. Bueno Delgado and C. Sánchez Moreno Ellart, eds., Movilidad forzada entre la Antigüedad Clásica y Tardía (Madrid 2015).

36 M.J. Groen-Vallinga and L.E. Tacoma, 'Contextualizing condemnation to hard labour in the Roman Empire', in C.G. De Vito and A. Lichtenstein, eds., Global Convict Labour (Leiden 2015), 49-78; F. Millar, 'Condemnation to hard labour in the Roman Empire from the Julio-Claudians to Constantine', Papers of the British School at Rome $5^{2}$ (1984), 123-147. 
the result of ad hoc decisions made by generals on the spot rather than by the senate and people of Rome. ${ }^{37}$ It does seem likely that during the Republican period some conquered peoples were moved around in the initial aftermath of conquest. ${ }^{38}$ For the Principate, when more systematic patterns of recruitment, discharge and settlement were established, there is a broad consensus that volunteers greatly outnumbered conscripts in both legions and auxilia. ${ }^{39}$ Those legionaries who survived to achieve an honest discharge were often resettled far from their original homes. It is difficult to calculate how many did reach this state, and how frequent it was for them to take the land allocation rather than sell it and/or re-enlist.

People were moved about, then, especially in the Republican period. But these processes affected only limited sectors of society: it was not equivalent in scale to the wholesale transplantation of populations practiced by Assyrian or Inka emperors. In almost all cases we are dealing primarily with individuals, and most of them males. A few female exiles are known, and there were certainly women among trafficked slaves. But almost none of these movements affected entire families let alone entire communities or peoples. Perhaps in a few areas subject to unusually high levels of slaving or recruitment, these processes will have had a cumulative impact on social structure. The best case for this so far has been made in respect of the Batavians, a high proportion of whom were apparently recruited and then returned home at the end of their period of service..$^{40}$ Similar arguments might be developed for other groups,

37 J.S. Richardson, Hispaniae. Spain and the Development of Roman Imperialism (Cambridge 1986); H.E. Herzig, 'Novum genus hominum: Phänomene der Migratione im römischen Heer', in E. Olshausen and H. Sonnabend, eds., 'Troianer sind wir gewesen'. Migrationen in der antiken Welt. Stuttgarter Kolloquium zur Historischen Geographie des Altertums, 82002 (Stuttgart 2006), 325-328.

38 F. Pina Polo, 'Deportaciones como castigo e instrumento de colonización durante la República romana. El caso de Hispania', in F. Marco Simon, F. Pina Polo and J. Remesal Rodriguez, eds., Vivir en tierra extraña. Emigración e integración cultural en el mundo antiguo (Barcelona 2004), 211-246; idem 2006, op. cit. (n. 32); idem, 'Deportation of indigenous population as a strategy for Roman dominion in Hispania', in A. Morillo Cerdán, R. Hanel and E. Martín Hernández, eds., Limes XX. Estudios sobre la frontera romana (Madrid 2009), 281-288.

39 P.A. Brunt, 'Conscription and volunteering in the Roman imperial army', Scripta Classica Israelica 1 (1974), 90-115.

40 Roymans 2004, op. cit. (n. 5); C. van Driel-Murray, 'Those who wait at home: the effect of recruitment on women in the Lower Rhine area', in U. Brandl, ed., Frauen und Römisches Militär. Beiträge eines Runden Tisches in Xanten vom 7. bis 9Juli 2005. British Archaeological Reports International Series 1759 (Oxford 2008), 82-91. 
such as the Syrians of Intercisa, ${ }^{41}$ and perhaps for some mining areas as well. Yet, like the city of Rome, these large effects arose not from planned interventions on the part of the emperors but incidentally and consequent on the way new imperial geographies of power emerged.

The chief exceptions to the rule that emperors did not regularly move entire peoples are a few incidents in which entire tribes from outside the empire were resettled within its crystallizing frontiers. This expedient seems to have been developed on the northern frontier where, after Caesar's wars, Rome controlled large spaces through which Iron Age peoples apparently were used to wander. ${ }^{42}$ In 38 в Agrippa brought the Ubii across the Rhine and settled them in territory formerly belonging to the Eburones. ${ }^{43}$ Debate continues over whether the Tungri moved or were moved in this period. ${ }^{44}$ Strabo records Aelius Catus transplanting 50,00o Getae from across the Danube into Thrace in his own lifetime. ${ }^{45}$ An inscription from the tomb of the Plautii near Tibur, recalls how Tiberius Plautius, when governor of Moesia in the late 5os and early 6os AD, led more than 100,00o Transdanubii into the empire to make them tributary subjects along with their wives and children, their leaders or their kings. ${ }^{46}$ There have been two surveys of the settlement of northern 'barbarians' within the areas controlled directly by Roman power. ${ }^{47}$ Both conclude that after a very small number of relocations dated to the reign of Augustus and his JulioClaudian successors, there were no more instances until the reign of Marcus Aurelius. De Ste Croix finds six cases before the end of the first century CE,

41 J. Fitz, Les Syriens à Intercisa. Collection Latomus (Bruxelles 1972). The general issues are discussed by I. Haynes, Blood of the Provinces. The Roman Auxilia and the Making of Provincial Society from Augustus to Diocletian (Oxford 2013).

T.C. Champion, 'Mass migration in later prehistoric Europe', in P. Sörbom, ed., Transport Technology and Social Change. Papers Delivered at Tekniska Museet Symposium No 2, Stockholm, 1979 (Stockholm 1980), 33-42; idem, 'Protohistoric European migrations', in I. Ness, ed., Encyclopaedia of Global Human Migration (Malden MA and Oxford 2013), $2463-2468$.

43 Tac. Germ. $28-29$.

44 F. Schön, 'Germanen sind wir gewesen? Bemerkungen zu den Tungri und Germani Cisrhenani und zum sogennanten taciteischen Namensatz (Tac. Germ. 2.2f.)', in E. Olshausen and H. Sonnabend, eds., 'Troianer sind wir gewesen.' Migrationen in der antiken Welt. Stuttgarter Kolloquium zur Historischen Geographie des Altertums, 82002 (Stuttgart 2006), 167-183.

45 Str. Geogr. 7.3.10.

$46 \quad$ ILS 986.

47 H. Wolff, Die Constitutio Antoniniana und Papyrus Gissensis 40 I (Köln 1976), 52-54; G.E.M. de Ste. Croix, The Class Struggle in the Ancient Greek World. From the Archaic Age to the Arab Conquests (London 1981), Appendix 3. 
another eight in the late second and early third centuries, followed by nineteen in late antiquity. The numbers only give a rough idea: most movements are attested only once, many presumably went unrecorded, and they were on a variety of scales. But the cumulative situation (Wolff's findings are similar) strongly suggests a long period in which there was no major resettlement in the north. Small scale mobility of individuals continued of course, such as the settlement of the Agri Decumates from Gaul and Germany, and of Dacia from Dalmatia. Once again all the evidence suggests these were not mass resettlements organized by the emperors. On a much smaller scale there are records of some groups in Africa settled within Roman provinces. Over all of this hangs the heavy ideological association of settled agricultural peoples and civilization, and the stigmatizing of nomads and other barbarians for their lack of moral as well as geographical fixity. 48

My conclusion is that although the emperors were well able to orchestrate deportations and projects of settlement on the whole this was not a power they chose to exercise. This marks Rome out as slightly unusual among early empires. How should we explain their reluctance or disinclination to move their subjects around?

Finding a definitive explanation for why something did not happen is always difficult. But let me close by offering a series of hypotheses.

The first can I think be rapidly dismissed but should be aired. Is it possible that Romans did not move populations out of respect for property rights or other ties between peoples and their homelands? Conceivably the negative responses to some resettlement of triumviral veterans in Italy may have deterred relocation projects in sensitive zones, but when we consider the importation of barbarian tribes, or the foundation of military coloniae like Timgad, or just the general manner in which provincials were treated, it seems a little unlikely that tact will provide the main answer. Perhaps the main argument in support of this is the increased instance of city foundations from the tetrarchy on, a period in which emperors seemed to have fewer scruples about ruling by fiat. It is true of course that the status of the city was different in the classical Mediterranean to the Ancient Near East, that emperors (like other benefactors) valued the praise lavished on them by cities, that

48 B.D. Shaw, "Eaters of flesh, drinkers of milk": the ancient Mediterranean ideology of the pastoral nomad', Ancient Society 13 (1982), 5-31. 
they were on occasion willing to grant them privileges and titles and even to be hailed as founders when they had done little to change their populations. Perhaps this 'beneficial ideology' in Vivian Nutton's phrase, did come to exercise some restraints on imperial action, so that they behaved a little less like Etruscan or Sicilian tyrants. But even if this were so (and it depends on the rather rose-tinted view of imperial power conveyed by honorific inscriptions and panegyric) this would only explain a reticence to interfere in the affairs of long-established cities. And when the emperors did wish, as they increasingly did from the late third century AD, to create great new capitals, they seem to have had no compunction in doing so.

A second possibility is that deportations and resettlements did happen but were simply not recorded. That might seem far fetched until we consider how little we know of, for instance, the date of the foundation of Alexandria in Egypt and the origins of the population that Fraser believed reached 250,000. We could ask the same question about the refoundation of Carthage and Corinth. In the latter case at least a transplantation of population from Rome seems most likely: in accordance with the general view that colonial schemes were seen as beneficial and popular projects we tend not to think of these in terms of deportation. But the truth is we know very little of the mechanics of filling new cities: Antinoopolis was apparently filled with volunteer settlers from the Fayum, ${ }^{49}$ but how widely that case can be generalized is not clear. Forced synoecism seems quite likely for the creation of new municipal capitals of the Augustan west or the cities Pompey created in Pontus. I have argued elsewhere that urbanization in parts of Gaul is difficult to envisage without some level of coercion on the part of local magnates. ${ }^{50}$ Perhaps deportation is less visible to us because unlike Assyrian kings who boasted of it as a sign of their power and also of their benevolent guardianship (gardnership?) of their subjects, Roman emperors did not feel so proud of it. The Res Gestae interestingly takes no credit for urban foundations, despite the effort invested into urban monumentality, and the creation in Nikopolis of a city-monument to the victory at Actium.

One final suggestion relates to ecology. Perhaps in the ancient Mediterranean human labour was never in as short supply as in some other parts of the world. The characteristic farming regimes of south east Asia, with which I began, were labour intensive. The rulers of states controlled the land they needed for

49 I am grateful to Rens Tacoma for this information.

50 G. Woolf, 'Urbanization and its discontents in early Roman Gaul', in E. Fentress, ed., Romanization and the City. Creations, Transformations and Failures. Journal of Roman Archaeology Supplementary Series 38 (Portsmouth, Rhode Island 2000), 115-132. 
rice cultivation but lacked a workforce, hence enclosure. Something similar applied in the Andes, if with different crops, because the lack of any animal traction put a premium on human labour. The ecology of northern Assyria could not have been more different, but clearly Assyrian rulers imagined that if they transplanted the right kind of settlers they could increase its productivity. Perhaps in ancient Rome a combination of widely available slave labour and also of free labourers willing to work for wages, and an environment which more often had too many people in it than too few, made the crucial difference.

London, January 2016 


\section{Invasions, Deportations, and Repopulation Mobility and Migration in Thrace, Moesia Inferior, and Dacia in the Third Quarter of the Third Century AD}

\section{Lukas de Blois}

\section{1 \\ Introduction}

Imperial systems have always promoted mobility and migration, in various ways. ${ }^{1}$ The Roman Empire was no exception to this rule. Regular journeys made by soldiers, officers, and administrators, displacements of armies and fleets in times of war, and movements of troops that were fighting bandits all were consequences of exercising imperial authority and had an impact on the provinces involved. And so did marching and looting bands of invading enemy warriors. Moving around they not only took all kinds of material booty but also deported inhabitants of the empire, thus causing a compulsory form of mobility and migration. In the third century $\mathrm{AD}$, particularly from about 250 to 280 , this happened with distressing regularity, in various parts of the Roman Empire. One region that in this way lost a good deal of its material welfare and a large part of its inhabitants was the lower Danube area, more specifically the region made up by the provinces of Dacia, Moesia inferior, and Thrace.

It is difficult to analyze the impact of warfare in the Balkans in the third quarter of the third century AD with a high degree of precision. The literary sources are mostly brief, sketchy, and late in time of composition, and our understanding of the countryside of the lower Danube region is still limited because few sites have been systematically excavated and published. ${ }^{2}$ Nonetheless there is just enough evidence to base some conclusions on, but these will unavoidably have an impressionistic character. Reliable evidence about numbers of people

1 To quote Greg Woolf's opening lecture of the Twelfth Workshop of the International Network Impact of Empire, Rome, La Sapienza, 17 June 2015; see Woolf, this volume.

2 See A.G. Poulter, 'Cataclysm on the Lower Danube: The destruction of a complex Roman landscape', in N. Christie, ed., Landscapes of Change. Rural Evolutions in Late Antiquity and the Early Middle Ages (Aldershot and Burlington vT 2004), 223. 
involved is still lacking, and any estimates would be tantamount to pure guesswork.

It is fortunate, though, that in recent times a few fragments of Dexippus' Scythica were added to our literary sources. They were found on a Viennese palimpsest and in 2014 preliminarily published by Günther Martin and Jana Grusková, with a commentary and a historical interpretation, and give us extra information about Decius' war against the Goths and other invaders (AD 250-251), and about the invasion of the Heruli and other bands of warriors in AD 267-268. ${ }^{3}$ Equally fortunate is that Andrew Poulter's work on Nicopolis ad Istrum, a town south of the Danube in Moesia inferior (modern central northern Bulgaria), where important excavations have been carried out, was published in 2007. This book mainly focuses on a later period, the years about 400 and the following two centuries, but also sheds some light on devastations dating back to the third century AD. ${ }^{4}$

The first thing to do is to give a survey of warfare in the lower Danube region in the second and third quarters of the third century AD. A long series of wars and invasions started in the lower Danube region in 238. Maximinus Thrax and his army had left Sirmium to march to Italy, which may have incited Gothic and other warrior bands to invade Dacia, Moesia inferior and Thrace. In 238 Tullius Menophilus, one of the men who had fought off Maximinus Thrax at Aquileia earlier in the same year, was sent to the Balkans to stop the ravaging of Roman territory by free Dacians (Carpi) and Goths. He fought the Carps and bought off the Goths. In 239 Viminacium in upper Moesia, apparently one of Menophilus' headquarters, became a colonia and received a mint. ${ }^{5}$

3 G. Martin and J. Grusková, “Scythica Vindobonensia” by Dexippus(?): new fragments on Decius' Gothic Wars,' Greek, Roman and Byzantine Studies 54 (2014), 728-54 (= Martin and Grusková 2014a) and “Dexippus Vindobonensis"(?). Ein neues Handschriftenfragment zum sogenannten Herulereinfall der Jahre 267/268', Wiener Studien 127 (2014), 101-20 (= Martin and Grusková 2014b).

4 A.G. Poulter, Nicopolis ad Istrum. A Late Roman and Early Byzantine City. The Finds and the Biological Remains (Oxford 2007).

5 See U. Huttner, 'Von Maximinus Thrax bis Aemilianus', in K.-P. Johne et al., eds., Die Zeit der Soldatenkaiser. Krise und Transformation des Römischen Reiches im 3. Jahrhundert n.Chr. (235-284) (Berlin 2008) I, 183. Petr. Patr. FHG 4. 186f, frg 8, tells us that the Carpi asked Tullius Menophilus to give them subsidies, just as the Goths were receiving, because they were more 


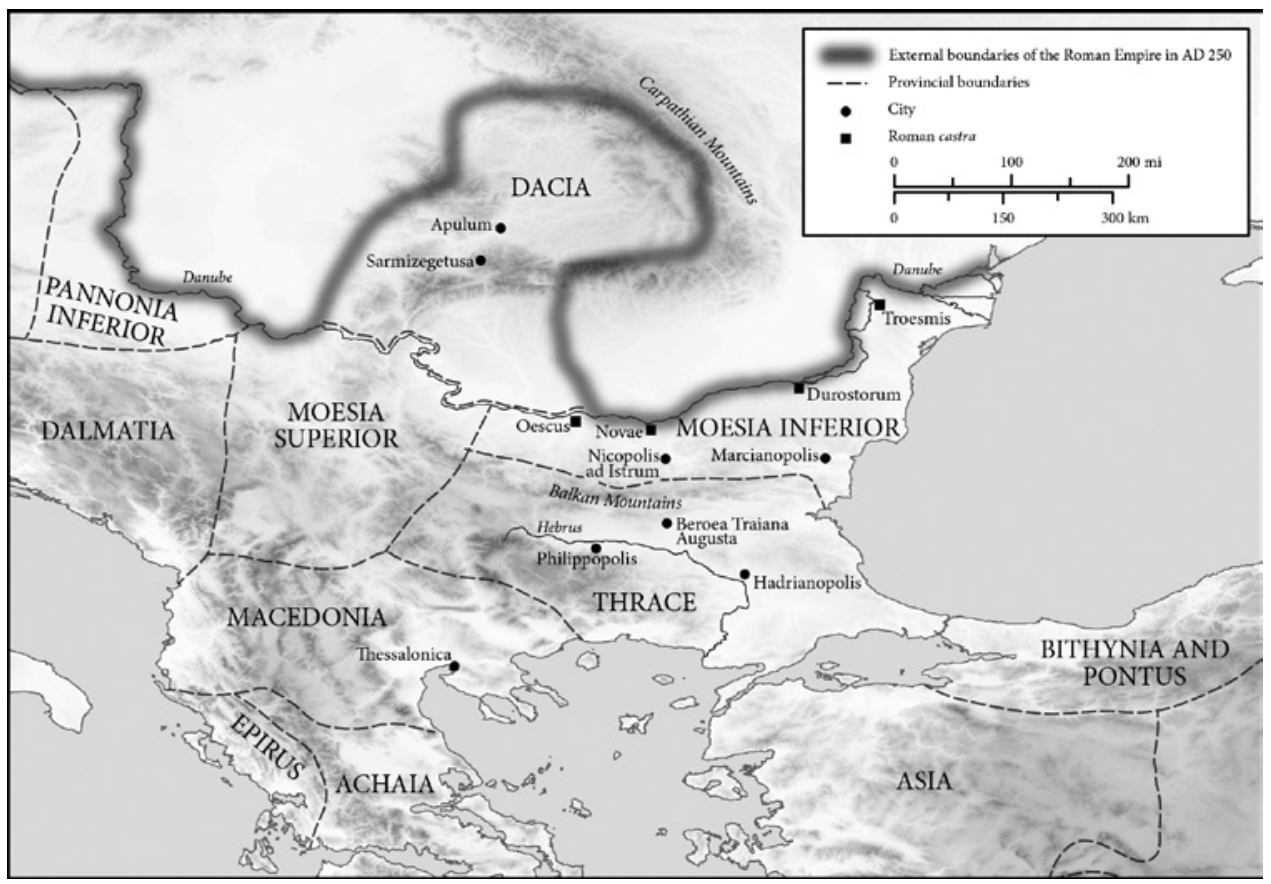

MAP 3.1

Map of the Roman Balkans in the third century AD. It shows the towns that are mentioned in the article.

About 247-248 the emperor Philip the Arabian may have been successful in a war against Carpi who had been ransacking Dacia. ${ }^{6}$ A setback was the usurpation of Pacatianus, probably a dux with an overarching command. The senator Decius, sent to his home region Illyricum, eliminated him but then successfully usurped imperial power himself. ${ }^{7}$ In his reign, in 250, the situation in the lower Danube region became much worse. Philip's withdrawal of

important than the Goths. Tullius replied that they might have subsidies, if they would submit to the Roman emperor.

6 On this war, see Chr. Körner, Philippus Arabs. Ein Soldatenkaiser in der Tradition des antoninisch-severischen Prinzipats (Berlin and New York 2002), 134-55; I. Piso, 'Der Krieg des Philippus gegen die Karpen', in idem, ed., An der Nordgrenze des römischen Reiches. Ausgewählte Studien 1972-2003 (Stuttgart 2005), 51-59.

7 On Pacatianus' coup and Decius' usurpation, see Körner 2002, op. cit. (n. 6), 282-300, and Huttner 2008, op. cit. (n. 5) I, 199-203. 
subsidies to the northern tribes, added to the departure of a large part of the Danube armies to Italy, to fight Philip, may have triggered the attack. ${ }^{8}$

There was enough booty for the barbarians to take, for in the Severan period these regions seem to have witnessed a period of unprecedented material prosperity, probably caused by the rise in pay that the military received under Septimius Severus and Caracalla. ${ }^{9}$ The Danube provinces housed large garrisons, especially in their border regions, and were also an important recruiting ground, which ultimately must have brought extra money into this area as well.

Probably in the spring of 250, Gothic warriors led by Cniva and Ostrogotha together with other tribes, such as Carpi and Bastarnae, invaded the Roman provinces Dacia (the target of the Carpi), Moesia inferior, and Thrace. One column of invaders unsuccessfully attacked Marcianopolis in the east of Moesia inferior, moved southwest along the Maritsa valley, and started to besiege Philippopolis, which was situated at the border between Macedon and Thrace. The other column under Cniva invaded central Moesia inferior, suffered a setback at Novae against the provincial governor Trebonianus Gallus, unsuccessfully attacked Nicopolis ad Istrum, where many inhabitants of the region had taken refuge, and then moved to Philippopolis, where it joined the other column. The emperor's army may have driven the Carpi out of Dacia, but was not completely successful against the Goths. Setbacks and successes succeeded one another. Decius could not drive the invaders off from Thrace and Moesia inferior. Nor could he relieve Philippopolis, where the local militia and the garrison were over-confident and eager to help the emperor to conquer the enemies. Their boldness induced the emperor to warn them in a long

8 J.F. Drinkwater, 'Maximinus to Diocletian and the "crisis", Cambridge Ancient History XII, 2nd ed. (Cambridge 2005), 37 remarks: "The first direct Gothic thrust into the Roman empire resulted from Philip's ending of subsidies to these people." It is not certain, however, that groups of Gothic warriors did not yet join raids into Roman territory earlier. See H. Wolfram, The Roman Empire and its Germanic Peoples (Berkeley, Los Angeles and London 1997), 44; M. Kulikowski, Rome's Gothic Wars from the Third Century to Alaric (Cambridge 2007), 18; and A. Goltz, 'Die Völker an der mittleren und nordöstlichen Reichsgrenze (mittlere und untere Donau sowie Schwarzmeergebiet)', in K.-P. Johne et al., eds., Die Zeit der Soldatenkaiser (Berlin 2008) I, 453-7, esp. 456.

9 See M.A. Speidel, 'Roman army pay scales', in idem, Heer und Herrscher im Römischen Reich der Hohen Kaiserzeit (Stuttgart 2009), 367, 371 (table 4), and 380 (table 7). On the relative prosperity of the Danube regions under the Severan emperors see A. Mócsy, Pannonia and Upper Moesia. A History of the Middle Danube Provinces of the Roman Empire (London and Boston 1974), 236 and A. Wilson, 'Urban development in the Severan Empire', in S. Swain, S. Harrison and J. Elsner, eds., Severan Culture (Cambridge 2007), 322-323. 
letter not to underestimate the Gothic warriors..$^{10}$ In the end Philippopolis was taken, which gave the Goths lots of booty. They also deported the inhabitants, which provided them with good artisans and people who could write and read. Attacking the invaders when they were returning home, laden with booty and prisoners, Decius and his army were lured into a trap in northeast Bulgaria, at Abrittus, and lost the battle, which cost his army many soldiers, and the emperor himself his life. ${ }^{11}$ Of course there were rumors that Decius had been betrayed by Gallus, as there had been about the praetorian prefect Philippus Arabs when the emperor Gordian III had died after losing the battle at Misiche against the Persians, early in AD 244. There had to be betrayal, a Roman emperor could not simply lose. ${ }^{12}$

What is the contribution of two recently discovered Dexippus fragments to this reconstruction of events? ${ }^{13}$ The first fragment gives us information about

10 Dexipp. frg. 23. References are to the new text and numbering of the fragments in G. Martin, Dexipp von Athen. Edition, Übersetzung und begleitende Studien (Tübingen 2006), 110-115.

11 In this reconstruction of events I follow Martin and Grusková 2014a, op. cit. (n. 3), 743-748. Evidence is mainly coming from literary sources. See Dexippus, frg. 24 Martin (siege of Philippopolis); Codex Vindobonensis gr. 73 fols. 194 and 195, in Martin and Grusková 2014a, op. cit. (n. 3), 734-736; Aur. Vict. Caes. 29.2-5; Zos. 1.23; Jordanes, Get. 101-3; Syncellus 459 (= Dexipp. frg. 17), and Zon. 12.20 .

12 Zon. 12.20 tells us that Decius engaged plundering barbarians and killed many. When they were hard pressed and offered to surrender all their loot if they were allowed to withdraw, Decius did not give in, but posted Gallus on the route of the barbarians. Gallus, however, told the barbarians where best to attack the emperor. Zonaras thinks that this happened in "Bosporus", which is impossible. Similar stories about betraying an emperor had been told about Philip the Arabian. In 23.5.17 Ammianus Marcellinus has the emperor Julian in 363 say, in a speech to his soldiers and officers:... iunior Gordianus, cuius monumentum nunc vidimus honorate, apud Resainan superato fugatoque rege Persarum, ni factione Philippi praefecti praetorio sceleste iuvantibus paucis in hoc, ubi sepultus est, loco vulnere impio cecidisset, "... the younger Gordianus, whose monument we just now looked upon with reverence, would have come back with equal glory [like Trajan, Lucius Verus, and Septimius Severus, LdB], after vanquishing the Persian king and putting him to flight at Rhesaena, had he not been struck down by an impious wound inflicted by the faction of Philippus." In reality Gordian's army lost the battle at Misiche, on the threshold of fertile south Mesopotamia, against the Persian king Shapur I, and the young emperor himself died - probably of his wounds - on the way back to Roman Mesopotamia. On Gordian's defeat and death see Res Gestae Divi Saporis 3-4 and Oracula Sybillina 13.13-20 with D.S. Potter, Prophecy and History in the Crisis of the Roman Empire (Oxford 1990), 36 and 203-11.

13 The text of these fragments: Codex Vindobonensis gr. 73 fols. 194 and 195, Martin and Grusková 2014a, op. cit. (n. 3), 734-736. 
the aftermath of the fall of Philippopolis, and shows Decius being concerned about the wrongdoing and loss of his auxiliary force. He assembles a large army (reputedly 80,00o, even without the auxiliaries!) and waits for the enemy to cross the river (the Danube, probably) to the other side. He is optimistic and wishes to liberate the Thracian captives. When the advance of Ostrogotha's force is reported to him, he tries to encourage his men through a speech, the beginning of which is reported in this fragment. This fragment attests to the fact that Ostrogotha is not a mythical figure but a historical leader of the Goths in this very war. Besides it shows that Decius had lost important auxiliary forces, probably Germanic allies. The second fragment contains a story about an episode of the siege of Philippopolis, which shows that the town was conquered by Cniva through betrayal and stratagems, by which he misled the Thracian and other defenders.

The consequences of Decius' demise to Thrace, Moesia inferior, and Dacia were enormous. Marauding barbarian bands may very well have stayed on in those regions until about 269 or even longer. Not all Goths and other invaders tried to get back over the Danube again, and every now and then new plundering bands entered those regions. For the next twenty-odd years Decius' successors never had enough armed forces at hand to drive the barbarians out or annihilate them completely, or they had to go and fight elsewhere after initial successes. Trebonianus Gallus, Decius' successor, went to Rome as soon as he could, to take up imperial power there, the $d u x$ Aemilianus gained some successes, was consequently acclaimed emperor, and took his forces to Italy to fight Gallus, which he successfully did but which again cost many Roman military lives. ${ }^{14}$ Gallienus, the son and co-emperor of Valerian, who had eliminated Aemilianus in September 253, put up his headquarters at Viminacium in 254, and was successful enough. He created a mobile army consisting of cavalry and detachments of infantry, which became efficient in tracking down and annihilating looting bands of invaders..$^{15} \mathrm{He}$ could not stay long enough, though.

14 On the reigns of Trebonianus Gallus and Aemilianus see Huttner 2008, op. cit. (n. 5), I, 21118. On the reigns of Valerian and Gallienus see A. Goltz and U. Hartmann, 'Valerianus und Gallienus', in K.-P. Johne et al., eds., Die Zeit der Soldatenkaiser. Krise und Transformation des Römischen Reiches im 3. Jahrhundert n.Chr. (235-284) (Berlin 2008) I, 225-95.

15 Gallienus' cavalry is explicitly mentioned by Cedrenus 1. 454. On Gallienus' new army, consisting of cavalry and infantry detachments, see H.-G. Simon, 'Die Reform der Reiterei unter Kaiser Gallien', in W. Eck, H. Galsterer and H. Wolff, eds., Studien zur antiken Sozialgeschichte. Festschrift F. Vittinghoff (Vienna and Cologne 1980), 435-451; M.J. Nicasie, Twilight of Empire. The Roman Army from the Reign of Diocletian until the Battle of Adrianople (Amsterdam 1998), 36f.; I. Piso, 'La réforme de Gallien', in idem 2005, op. cit. (n. 6), 392; P. Cosme, L'armée romaine (Paris 2009), 212-215. Pierre Cosme, like Michael 
In 256 he had to go west, to defend Gaul against invading Franks. About 262 and 267 new waves of plundering invaders, coming over land and through the Dardanelles, attacked the Balkans and western Asia minor. In 262 the Roman garrison of Byzantium, which had been put there by Valerian from the East, a few years before this emperor was taken prisoner by the Persians, ${ }^{16}$ mutinied and plundered their garrison city, which induced Gallienus to punish these soldiers harshly, just before he celebrated his decennalia. ${ }^{17}$ The damage was serious in 262, but even worse in 267 to 271 . The greatest war Gallienus had to fight during his sole reign was the one in the Balkans and the adjacent parts of Greece and Asia minor, which came about in 267 , and only ended during the reign of the emperor Aurelian (AD 270-275) ${ }^{18}$ Goths, Heruls and other invading groups entered the empire by land and sea. As before the Pontic region was invaded again. Penetrating into northwest Asia minor, warrior bands attacked Cyzicus. ${ }^{19}$ Other plundering groups, having crossed the sea, entered the region of the lower Danube. They were defeated by two Byzantines, Cleodamus and Athenaeus, who also fortified many cities. ${ }^{20} \mathrm{~A}$ plundering group that was progressing by sea was beaten by a $d u x$ called Venerianus who was killed in the action himself. ${ }^{21}$

One of the Dexippus fragments adds considerably to our knowledge, showing that one column of invaders crossed Macedonia and Thrace and vainly attacked Thessalonica, where the defenders on their ramparts bravely withstood the invaders. Thereupon the attacking warriors, having heard that more to the south a rich booty was awaiting them, gave up and marched into Greece, to Athens and Achaea. The Greeks manned the passes of Thermopylae under

Whitby, seems to think that Gallienus developed his new army on the Rhine, but he must have done this earlier, on the Danube. See M. Whitby, 'Emperors and armies, AD 235-395', in S. Swain and M. Edwards, eds., Approaching Late Antiquity. The Transformation from Early to Late Empire (Oxford 2004), 161 .

Zos. 1.36.1-2 tells us that Valerian, having heard of disturbances in Bithynia, sent a trusted commander named Felix to Byzantium (about AD 258-259). On Felix see $P I R^{2} \mathrm{~F} 142$. He was an experienced man if he was the same Felix who is mentioned in G. Barbieri, L'albo senatorio da Settimio Severo a Carino (Rome 1952), nr 1113 as consul ordinarius in 237 and so possibly an old friend of Valerian. See L. de Blois, The Policy of the Emperor Gallienus (Leiden 1976), 31 note 39 . HA Gall. 6.8 and 7.2.

18 On this war see Goltz and Hartmann 2008, op. cit. (n. 14) I, 283-7 and M. Geiger, Gallienus (Frankfurt am Main 2013), 145-151. HA Gall. 13.8.

20 HA Gall. 13.6-10.

21 HA.Gall. $13 \cdot 7$. 
the command of the governor of Achaea, Marianus, the Athenian Philostratus and the Boeotarch Dexippus - who is not the same as the Athenian historiographer Dexippus. The Boeotarch Dexippus tried to motivate his makeshift army through an adhortative oration. All in vain, for the Germanic warriors broke through to Athens, where the Athenian Dexippus had to fight them, which he did, trusting that a nearby imperial fleet would come to his rescue. ${ }^{22}$ During those years marauding bands swerved everywhere in the Balkans and adjacent Greece and Asia minor. Gallienus conquered one of the invading warrior groups at the river Nessos or Nestos, at the border between Thrace and Macedonia, but had to leave the region again too soon, to fight the usurper Aureolus. ${ }^{23}$ Only under the emperors Claudius and Aurelian one marauding band after the other was defeated, dispersed, and destroyed. ${ }^{24}$ To Moesia inferior, Thrace and probably also Dacia, all this came down to some twenty years of turmoil, human and material losses, impoverishment, and demographic decay through enhanced mortality and deportations. According to Roger Batty, marauding barbarian bands may very well have stayed on in Moesia

22 Dexipp. frg. 25.4; Codex Vindobonensis gr. 73 fols. 192-193, G. Martin \& J. Grusková 2014b, op. cit. (n. 3), 106-109. Cf. Aur. Vict. Caes. 33.3. See also HA Gall.13.6-10. The Historia Augusta is of some serious value here because when writing about the northwestern and Pontic parts of Asia minor, Greece, and Balkanic regions the author of the Historia Augusta is probably following Dexippus, whose Scythica concentrated on these territories. Dexippus is explicitly mentioned in HA Gall.13.8. There may have been two Dexippi involved. The Boeotarch Dexippus who fought at Thermopylae was not the same as the Athenian historiographer who tried to harass the Heruls in Attica and was honored at Athens ( IG $2^{2} 3669$, translated from the Greek by O.J. Hekster, Rome and its Empire, AD 193284 (Edinburgh 2008), 116). The Dexippus who commanded a local militia in Attica, called P. Herennius Dexippus, also held an adhortative speech before his men. See Dexipp. frg. 25 (Hekster 2008, op. cit. 115f.). The Boeotarch Dexippus must have been from Boeotia, as practically all former Boeotarchs had been, and almost certainly was C. Curtius Dexippus, known from an inscription of Chaeronea or Lebadea, $I G$ 7.3426. The inscription is dated by the script to about 250. This Dexippus was three times Boeotarch, lifetime high-priest of the Sebastoi, probably in his native town, and logistes of Chaeronea; he must therefore have been Boeotarch at least twice more. I owe this information to C.P. Jones.

On the battle at the river Nessos or Nestos, a small stream on the border between Macedonia and Thrace, see Syncellus 467. Cf. Zos. 1.39.1. See Geiger 2013, op. cit. (n. 18), 150. On Aureolus' usurpation of imperial power, ibidem, 173-84.

On Claudius II, Aurelian and the Gothic war see U. Hartmann, 'Claudius Gothicus und Aurelianus', in K.-P. Johne et al., eds., Die Zeit der Soldatenkaiser. Krise und Transformation des Römischen Reiches im 3. Jahrhundert n.Chr. (235-284) (Berlin 2008) I, 301-4; 314f. 
inferior from 250 until about $269 .{ }^{25}$ Dacia and Thrace did not fare any better. In Caesares 34.3 Aurelius Victor remarks that around AD 269, the invaders almost had been living permanently in those parts of the Roman empire, ${ }^{26}$ which is much worse than one or two vehement but brief attacks.

Could we estimate from parallel phenomena what was about to happen when marauding enemies stayed on for decades in a region and virtually lived there? We could think of southern Italy in the period of the Second Punic War. ${ }^{27}$ Continuous violence, plunder and devastation caused many to die. Others were deported into slavery. Surviving peasants who had been pushed below the minimum requirement for subsistence were induced to leave their estates. Confronted with empty stores, destroyed fields, and stolen livestock, added to a continued threat of hostile actions, they left their farms in search of more secure conditions of survival. They could have coped with one or two vehement attacks, but not with continuous misery. Such things, added to plague and deportation, must have happened in the Balkan region during the third quarter of the third century, and undoubtedly diminished the number of productive people. Many people must have died because of violence and a lack of food, and others were deported, as were the inhabitants of Philippopolis. Yet others must have gone to safer places, for example to the coastal cities, where food could more easily be imported, or to Moesia superior, Greece and Asia minor. ${ }^{28}$

There is a good explanation for such forms of mobility. In his book on the grain market in the Roman empire, Paul Erdkamp shows that the high cost of overland transport in antiquity virtually ruled out the conveyance of large amounts of corn to inland areas, unless any government forced people to do so. Instead, hungry people in war-ridden inland regions would run to the coast, expecting that food would be more readily available there. When the fields in Aemilia in Italy lay bare as a result of the war against the Goths in the sixth century AD, the inhabitants fled to neighboring Picenum, on the coast of the Adriatic Sea, expecting that the famine would be less severe there. It turned out

25 R. Batty, Rome and the Nomads. The Pontic-Danubian Realm in Antiquity (Oxford 2007), $388 f f$.

26 Aur. Vict. Caes. 34.3: the emperor Claudius wishes to expel Goths, ... quos diuturnitas nimis validos ac prope incolas effecerat. Cf. Oros. 7.23.1: Claudius...vvoluntate senatus sumpsit imperium statimque Gothos, iam per annos quindecim Illyricum Macedoniamque vastantes, bello adortus incredibili strage delevit.

27 See P.P.M. Erdkamp, Hunger and the Sword. Warfare and Food Supply in Roman Republican Wars (264-3o B.C.) (Amsterdam 1998), 208-240, esp. 240.

28 This a hypothesis. It should be corroborated by future research. 
that the hope of rescue from overseas was false. The historiographer Procopius claims to have been present in the region at the time and paints a vivid picture of mass starvation and its consequences. ${ }^{29}$

\section{Traces of Third-Century Turmoil and Devastation}

There are archaeological traces of third-century turmoil. The clearest example was provided by research at Nicopolis ad Istrum. ${ }^{30}$ In his publication on the excavations and findings, Andrew Poulter concludes that the Severan era in this town was even more prosperous than the second century up to the invasions under Marcus Aurelius had been, but that this happy situation did not last. Already before the middle of the third century fine extramural houses had to be abandoned and were burnt down. For the third quarter of the third century there are traces of devastations. The town was besieged on at least two occasions. The south gate was blocked and the defensive ditch was extended. The extramural area would seem to have been abandoned until the closing years of the century when the frontier was restored. The situation was not as bad as about AD 400, though. At the second workshop of the Network Impact of Empire, at Nottingham in 2001, Poulter made clear that in Thrace and Moesia inferior about AD 400 the economy completely collapsed and well-populated towns were transformed into tiny fortresses. The villa economy disappeared and steep demographic decline was unmistakable. ${ }^{31}$ In this magnitude this did not yet happen in the second half of the third century. Instead, there was some recovery under Diocletian and Constantine. The structure of the built-up environment of Nicopolis suggests that the town in the fourth century had a very small intramural population of several hundred. Some of the finds suggest that there was still wealth in the town, at least in the hands of some of those who were privileged and owned a substantial dwelling.

29 P.P.M. Erdkamp, The Grain Market in the Roman Empire. A Social, Political, and Economic Study (Cambridge 2005), 198-9, referring to Procop. Bella 6.20.18.

$30 \quad$ See Poulter 2007, op. cit. (n. 4), 9-11.

31 A.G. Poulter, 'Economic collapse in the countryside and the consequent transformation of city into fortress in Late Antiquity', in L. de Blois and J. Rich, eds., The Transformation of Economic Life under the Roman Empire. Proceedings of the Second Workshop of the International Network Impact of Empire (Roman Empire, c. 200 B.C.-A.D. 476), Nottingham, July 4-7, 2001 (Amsterdam 2002), 244-66. See also Poulter 2004, op. cit. (n. 2), 223-53, esp. 242-7. 
Thrace and Moesia inferior may well have owed this partial recovery not only to the tetrarchy but also to the emperor Aurelian's restoration policy. This emperor gave up Dacia, about 271, and moved its Roman population to Moesia. Enemy pressure on Dacia had clearly become too strong and continuous, and a repopulation of Moesia inferior and Thrace was badly needed after the barbarians had been driven out. We are told:

cum vastatum Illyricum ac Moesiam deperditam videret, provinciam Transdanuvinam Daciam a Traiano constitutam sublato exercitu et provincialibus reliquit, desperans eam posse retineri, abductosque ex ea populos in Moesia conlocavit appellavitque eam Daciam, quae nunc duas Moesias dividit.

On seeing that Illyricum was devastated and Moesia was in a ruinous state, Aurelian abandoned the province of trans-Danubian Dacia, which had been formed by Trajan, and led away both soldiers and provincials (exercitus and provinciales), giving up hope that it could be retained. The people whom he moved out from it he established in Moesia, and gave to this district, which now divides the two provinces of Moesia, the name of Dacia. $^{32}$

In 9.15.1 Eutropius is telling us the same, in very similar wordings. He must have used the same source. ${ }^{33}$ In 1.71.1 Zosimus relates that the emperor Probus admitted groups of Bastarnae into Thrace and settled them there. From that moment onwards they lived in conformity with Roman law. According to HA Probus 18.1, the number of those Bastarnae was large, even one hundred thousand. This is not very plausible, but there clearly was a tradition that this emperor settled a multitude of Bastarnae in Thrace. Under the tetrarchy Thrace received people from Asia minor. The tetrarchs did similar things in the country of the Treveri and in Belgica, by settling Laeti and Franci there. ${ }^{34}$ If these waves of new settlers could be accommodated in Moesia inferior and Thrace without much

$32 \quad$ HA Aurelian 39.7; See Wolfram 1997, op. cit. (n. 8), 45; A. Watson, Aurelian and the Third Century (London and New York 1999), 54-6, 155-7; Hartmann 2008, op. cit. (n. 24) I, 315 (The legions XIII Gemina and V Macedonica were stationed at the lower Danube, at Oescus and Ratiaria).

33 See also Syncellus 470.

34 Paneg. Lat. 8.21.1. 
friction and within a relatively short period, this province must have lost a lot of people before, and consequently was in need of productive settlers. This was forced migration on a large scale, going hand in hand with a shortening of defensive lines and a restoration of the lower Danube frontier. Such a restoration of defenses necessitated a strengthening of agricultural and manufactural forces in the army's hinterlands, an improvement of the production of necessary goods and food in the zone right behind the military units along the border. This would make logistical lines comfortably short. The alternative would have been to transport food and goods from further away to the Danube, by land and sea, for example from Egypt and Asia minor. Particularly land-transport, however, would have put heavy demands on local communities along transit routes, for example for lodging and means of transportation. Such demands caused complaints and petitions to governors and emperors already in the first half of the third century, also in the Balkans and Asia minor, as is testified by some well-known inscriptions. ${ }^{35}$ And the thinner the density of population, the heavier the burdens for the communities situated there, because the quantities of army forces could not always be adapted to the numbers of inhabitants in their backyard. If population had gone down heavily in the Balkans, this would have serious consequences to military logistics and to the burdens the remaining population would have to bear. So these forced migrations were necessary, if the emperors Aurelian, Probus, and Diocletian wished to restore a vigorous defense at the Lower Danube border, without over-burdening the direct hinterlands with demands of annona and angareia. In other words, under-population and a lack of productive hands in the direct hinterlands of large armies did not go hand-in-hand with sound military logistics.

See T. Hauken, Petition and Response. An Epigraphic Study of Petitions to Roman Emperors 181-249 (Bergen 1998), 35-41, either AD 197-211 or 244-249, a petition about extortion by military men from Aga Bey Köyü in Asia minor, a village situated on an imperial domain in Lydia; 203-14, AD 193, a letter by Pertinax and the provincial governor to Tabala about soldiers turning off the prescribed road and demanding all kinds of things; 215 f., a petition from Euhippe in Asia against soldiers turning off the road and demanding commodities and services, AD 211-213; 217-43, a complaint from Takina in Phrygia, AD 212-213, against soldiers demanding commodities and services; 74-139, a petition to Gordian III from Skaptopare, situated between two military camps, against all kinds of military misconduct; and 140-161, AD 244-246, a petition to Philip from Aragua, situated on an imperial domain in Asia, against soldiers leaving the main roads and harassing the village. See also S. Mitchell, 'The administration of Roman Asia from 133 BC to AD 250', in W. Eck, ed., Lokale Autonomie und römische Ordnungsmacht in den kaiserzeitlichen Provinzen vom 1. bis 3.Jh. (Munich 1999), 17-46, esp 41. On the petition by the villagers of Skaptopara see also S. Connolly, Lives behind the Laws (Bloomington, IN 2010), 27-38. 


\section{$5 \quad$ Mobility and Migration}

In the third quarter of the third century Thrace, Moesia inferior, and Dacia witnessed a lot of migration and mobility. First of all, there were movements of Roman and enemy forces, over more than twenty years, which had a negative impact on the density and prosperity of the regional populations. Secondly, there were deportations. The most spectacular one was the deportation of many people from Philippopolis, but there must have been more, in such a long period of invasion and armed violence. Thirdly, there was a voluntary concentration of people within the walls of fortified towns, as at Nicopolis ad Istrum. Fourthly there was forced migration, for example of at least a large part of the Roman population of abandoned Dacia into Moesia inferior. And last but not least, there was resettlement to repair demographic decay and strengthen the logistical basis of strong border garrisons. The conclusion must be that successive events in the lower Danube regions in the third quarter of the third century AD once more show that prolonged intensive warfare in a region unavoidably results in manifold mobility and migration.

Nijmegen, January 2016 


\title{
Viri Militares Moving from West to East in Two Crisis Years (AD 133 and 162) ${ }^{1}$
}

\author{
Anthony R. Birley
}

\section{Introduction}

Something needs to be said about the term viri militares. Livy applied the term to Laelius and other men on Scipio's staff, to whom the general awarded decorations. ${ }^{2}$ Sallust uses the term homines militares for two praetors of 63 вс. ${ }^{3}$ His prime example of a homo militaris is M. Petreius, who had "won great glory in the army for more than thirty years as tribune or legate or praetor." Tacitus seems to have applied the term to men of lower rank, when lamenting how under Domitian "so many armies had been lost, in Moesia and Dacia, in Germany and Pannonia, by the folly or cowardice of their generals, so many military men, with so many cohorts, had been defeated in battle and taken prisoner." ${ }^{5}$

Augustus' reform of the political and military system reduced the opportunities for lengthy service and of course for winning glory. Corbulo had been up against the changed conditions under Claudius, and is said by Tacitus to have reacted to the emperor's ban on his campaigning beyond the Rhine by sighing

1 This paper is a postscript to A.R. Birley, 'Two governors of Dacia Superior and Britain', in V. Iliescu, D. Nedu, A.-R. Barboş, eds., Graecia, Roma, Barbaricum. In Memoriam Vasile Lica (Galati 2014), 241-59, where it is shown that the Hadrianic expeditio Brittannica named in two inscriptions must refer to Hadrian's visit to Britain in AD 122; and that the careers of the two officers known to have served in it (ILS 2726 and 2735) cannot be taken to prove that there was a 'second war' in the island during his reign, as is still claimed.

2 Liv. 30.15.13: Laelium deinde et ipsum conlaudatum aurea corona donat; et alii militares viri (...) donati.

3 Sall. Cat. 45.1.

4 Sall. Cat. 59.6: homo militaris, quod amplius annos triginta tribunus aut legatus aut praetor magna gloria in exercitu fuerat.

5 Tac. Agr. 41.2: tot exercitus in Moesia Daciaque et Germania et Pannonia temeritate aut per ignaviam ducum amissi, tot militares viri cum tot cohortibus expugnati et capti. 
that "Roman generals were fortunate in former times!"6 Tacitus comments that his father-in-law was aware that "a great reputation was no less dangerous than a bad one."

Rome's armed forces in the Principate were based around the periphery and the empire had no mobile field army. Hence it was necessary to move legions and other units from one front to another when a crisis erupted. What was intended to be temporary sometimes became permanent redeployment. Simultaneous wars on two fronts created major problems. Not till the later second century did it become normal practice to send detachments, vexillationes, instead of whole legions, from one army to another, for the duration of a campaign. All these movements and transfers were documented eighty years ago in the great encyclopaedia article by Emil Ritterling, still basic, although requiring modification from time to time. ${ }^{8}$ As for the auxilia, these smaller but much more numerous units were regularly moved back and forth. Details about their whereabouts now constantly require updating, mainly because of the incessant flood of new diplomas unearthed through metal-detecting. ${ }^{9}$ The great wars of Trajan's reign made frequent transfers necessary. ${ }^{10}$ Meanwhile the 'Who's Who' of the equestrian officers, edited (in Latin) by Hubert Devijver, has made it far easier to keep track of this important group. ${ }^{11}$ The new diplomas

6 Tac. Ann. 11.20.2: beatos quondam duces Romanos. The aborted campaign is described ibid. 18.1-20.1.

7 Tac. Agr. 5.4; cf. ibid. 17.2 on Frontinus, "a great man insofar as was permitted", vir magnus, quantum licebat; and 39.2, "good generalship was a quality reserved for the emperor", ducis boni imperatoriam virtutem esse.

8 E. Ritterling, art. 'Legio', Realencyclopädie der classischen Altertumswissenschaft 12.1 (1924), 1211-1328; 12.2 (1925), 1329-1829. The two volumes edited by Y. Le Bohec and C. Wolff, Les légions de Rome sous le Haut-Empire. Actes du Congrès de Lyon (17-19 septembre 1998) (Paris 200o), devote 754 pages to revising Ritterling.

$9 \quad$ More of these have been published by Werner Eck than by anyone else. One must also single out the invaluable series of supplements to the $C I L 16$ collection, Roman Military Diplomas, abbreviated RMD: 1 (1978), 2 (1985), 3 (1994), ed. M.M. Roxan; 4 (2003), edd. eadem and P. Holder; 5 (2006), ed. P. Holder, all London. Volume 6, ed. P. Holder, is nearing completion.

10 As an example of the astonishing quantity of information that can be gained from diplomas one may cite P.A. Holder, 'Auxiliary deployment in the reign of Trajan', Dacia n.s. $5^{0}$ (2006), 141-174. Note here, his citing at p. 154, cf. 144, an ala, listed in AD 114 as missa in expeditionem from the army of Pannonia inferior; and at p. 143, discussing cohorts listed in the army of Moesia superior in AD 114 as translatis in expediti[one]. His discussion of the subsequent deployment of these units is instructive.

11 This work, the Prosopographia Militiarum Equestrium quae fuerunt ab Augusto ad Gallienum, here abbreviated $P M E$, is in six volumes: 1 (A-I, 1976), 2 (L-V, 1977), 3 
have also produced a great deal of extra information about suffect consuls and provincial governors, particularly for the period from Trajan to Antoninus Pius. $^{12}$

For officers of both senatorial and equestrian rank it was normal to move from province to province: detailed careers where known show for the most part that senators and knights, especially the former, served in different armies at successive stages; for both there was a certain regularity in the career structure. This is more obvious with the equites Romani, for whom the stages were in due course labelled the tres militiae; and later there was the quarta militia as well. ${ }^{13}$ The provinces governed by legati Augusti pro praetore did not have similar ranking designations. In the Julio-Claudian period, when the imperial provincial system was still developing, one cannot detect real regularity in the appointment of governors. It is striking how Tacitus records how Nero tackled the sudden crisis in the east shortly after his accession. His initial measures, guided by his advisers Burrus and Seneca, were carefully watched, and approved, and "there was delight among the senators that he had appointed Domitius Corbulo to take charge of holding onto Armenia and that room

(Indices, 1980), 4 (Suppl. 1, 1987), 5 (Suppl. 2, 1993), 6 (laterculi of units, 2001), all published at Leuven. Volume 6, the 'laterculi alarum cohortium legionum', edited by Ségolène Demougin and Marie-Thérèse Raepsaet-Charlier, appeared four years after Devijver's death in 1997. A minor irritation is that Devijver declined to repeat in his $P M E$ the career details of the more than 130 officers covered in his 'trial run', De Aegypto et exercitu Romano sive Prosopographia Militiarum Equestrium quae ab Augusto ad Gallienum seu statione seu origine ad Aegyptum pertinebant. Studia Hellenistica 22 (Lovanii 1975), giving only simple cross-references. Cf. n. 46 below for an example.

12 This is an appropriate place to register the publication in autumn 2015 of the final volume of $P I R^{2}$, Pars VIII Fasciculus 2, most of it covering persons whose names began with V, as well as a handful of names beginning $\mathrm{X}$ and $\mathrm{Z}$. The first volume of the second edition, covering A and B, of this indispensable work appeared in 1933, under the editorship of Edmund Groag and Arthur Stein. Due tribute must be paid to those who kept the great work going in extraordinarily difficult times and have brought it to completion after 82 years.

13 Still basic is E. Birley, 'The equestrian officers of the Roman army', first published in the Durham University Journal (December 1949), 8-19, repr. in idem, Roman Britain and the Roman Army. Collected Papers (Kendal 1953), 133-53; and again, rev. in idem, The Roman Army. Papers 1929-1986 (Amsterdam 1988), 147-65. See also idem, 'Beförderungen und Versetzungen im römischen Heere', Carnuntum Jahrbuch 1957 (Wien 1958), 3-20, and the revised version of that paper, 'Promotions and transfers in the Roman Army: senatorial and equestrian officers', in idem 1988, op. cit., 93-114, at 105-13. 
seemed to have been cleared for virtues."14 One might render virtutes here as 'merit', as opposed to corruption.

In the later first century and above all in the period from Trajan to the Antonines, patterns of promotion for senators in the emperors' service assumed a certain regularity. The number of imperial provinces governed by ex-praetors gradually increased with the annexation of new territory and the change in status, or subdivision, of existing provinces. Further one-legion provinces in which the legate of the legion was also the governor, were: Judaea, from 70 until c. 117; Arabia from Trajan onwards; Pannonia inferior from Trajan to Caracalla; Dacia superior, from Hadrian to Marcus Aurelius; Raetia and Noricum under Marcus Aurelius; Syria Phoenice under Severus; Britannia inferior from Caracalla onwards. There were never more than six of these one-legion provinces at any one time. Before Marcus Aurelius only one case is known of a man governing two praetorian imperial provinces, Pompeius Falco under Trajan. In the 16os and 170s, perhaps due to a shortage of qualified expraetors after war and plague, more can be identified; further examples are found in the third century.

Most legati Augusti pro praetore of consular status governed provinces with more than one legion. Exceptions were the very large province of Hispania Tarraconensis, still governed by an ex-consul after its garrison was reduced to one legion in the 7os; Dalmatia, which under Trajan regained a consular governor after losing its legionary garrison; and Pontus-Bithynia, which was originally governed by praetorian proconsuls, and never had a legionary garrison, but from Marcus Aurelius onwards was assigned to consular legates. All the consular imperial provinces could be governed by recent ex-consuls, but Tarraconensis, Britain and Syria, later also the 'Three Dacias' (after they were reunited in the 16os), were mostly assigned to men who had previously governed one of the other consular provinces, namely the two Germanies, the two Moesias, Upper Pannonia, Cappadocia, and Syria Palaestina. Although two of these 'junior' consular provinces, Upper Pannonia and Lower Moesia, for much of the Principate had as many legions, three, as did Britain, Syria and the Three Dacias, they were less exposed to external threat. As for Tarraconensis, its great prestige as one of Rome's oldest and largest provinces no doubt meant that senior men were glad to govern it. The length of tenure depended on the emperor. Most probably served for about three years. Patronage and bribery

Tac. Ann. 13.8.1: praeter suetam adulationem laeti, quod Domitium Corbulonem retinendae Armeniae praeposuerat, videbaturque locus virtutibus patefactus. Cf. A.R. Birley, Locus virtutibus patefactus? Zum Beförderungssystem in der Hohen Kaiserzeit. RheinischWestfälische Akademie der Wissenschaften. Vorträge G 318 (Opladen 1992). 
probably played less of a role with the most senior posts than at lower levels. The emperors and their advisers generally kept to their own 'rules'. Not least, a fairly standard order of seniority for provincial commands can be observed for those who governed more than one province after their consulship. ${ }^{15}$ Very few men governed more than two consular provinces, although exceptions are found at times of serious warfare. ${ }^{16}$ But after one or more consular commands in the emperors' service, most senators could look forward only to a year as proconsul of Africa or Asia.

Two second-century governors who moved from one end of the empire to the other in unusual career moves deserve highlighting. Both recall the appointment of Corbulo to his special command in the east in AD 54, but no literary source resembling Tacitus survives to describe the contemporary reactions. In the early 130s, Sextus Julius Severus (cos. 127) was summoned to Judaea by Hadrian, from Britain, where he was governor, to suppress the revolt of Bar Kochba, as specifically recorded by Cassius Dio. Judaea, which had only recently become a two-legion province, thus gained an ex-consul as governor; but it was not a 'normal' posting to follow the command of a threelegion province, such as Britain. ${ }^{17}$ Almost thirty years later the Parthians, who had been threatening war in the last months of Antoninus Pius' reign, invaded the empire. ${ }^{18}$ The result was a disaster for Rome at Elegeia: according to Dio it

15 See e.g. E. Birley, 'Senators in the emperors' service', Proceedings of the British Academy 39 (1954), 197-214, repr. in idem 1988, op. cit. (n. 13), 75-92; and idem 1988, op. cit. (n. 13), 93-105; W. Eck, 'Beförderungskriterien innerhalb der senatorischen Laufbahn, dargestellt an der Zeit von 69 bis 138 n. Chr.', Aufstieg und Niedergang der römischen Welt 2.1 (Berlin and New York 1974), 158 ff.; G. Alföldy, Konsulat und Senatorenstand unter den Antoninen. Prosopographische Untersuchungen zur senatorischen Führungsschicht (Bonn 1977); A.R. Birley, The Fasti of Roman Britain (Oxford 1981), 3 ff.; idem 1992, op. cit. (n. 14), passim; idem, The Roman Government of Britain (Oxford 2005), $3 \mathrm{ff}$.

16 A list is given by A.R. Birley, 'Senators as generals', in G. Alföldy, B. Dobson, and W. Eck, eds., Kaiser, Heer und Gesellschaft in der Römischen Kaiserzeit. Gedenkschrift für Eric Birley. Heidelberger althistorische Beiträge und epigraphische Studien 31 (Stuttgart 2000), 97-119, at 111-114.

17 As Gaius Julius Severus from Ankara was also active in the same theatre of war at this time, as legate of the Syrian legion IV Scythica and then as acting governor of Syria $\left(P I R^{2} \mathrm{~J}\right.$ 573), the man who defeated the Jewish rebels is here called Sextus Julius Severus throughout-even if he changed his name in the 130s, see below.

HA, M. Ant. Phil. 8.6: fuit eo tempore etiam Parthicum bellum, quod Vologessus paratum sub Pio Marci et Veri tempore indixit. The dispatch by Antoninus Pius of the legate of the Syrian legion XVI Flavia fidelis, L. Neratius Proculus, "to lead detachments into Syria because of the Parthian war", took place at the very end of Pius' reign, as shown by P. Weiß, 'Militärdiplome und Reichsgeschichte: Der Konsulat des L. Neratius Proculus und 
involved the destruction of a legion with all its officers and the suicide of the Cappadocian legate, M. Sedatius Severianus (cos. 153), called by Lucian "that stupid Celt" (stupid because he had fallen under the influence of Alexander the false prophet of Abonuteichos, a Celt because he was from Poitiers). ${ }^{19}$ To tackle the new eastern crisis, the man who was clearly recognised by Marcus Aurelius and Lucius Verus as their most competent general, M. Statius Priscus (cos. ord. 159), was summoned from Britain, shortly after he had arrived there. Each of these governors evidently took selected officers with them. In both cases the emperor of the day chose as commander to deal with the crisis men who were at the opposite end of the empire, surely a sign that the best qualified military man of the time was generally assigned to govern Britain. Sextus Julius Severus had, further, already had at least fifteen years of service in the Roman army when chosen, Statius Priscus only slightly less, albeit his first five years had been as an equestrian officer. ${ }^{20}$ In both cases, the senators and the informed public may well have applauded the choice with the comment: locus virtutibus patefactus.

\section{Hadrian's Dispatch of Sextus Julius Severus to Judaea}

The general's most detailed epigraphic career record is on a statue-base from Burnum in Dalmatia (his home town was Aequum in that province). He was still named Sextus Julius Severus when cos. suff. in 127, but, after presumed adoption by Gnaeus Minicius Faustinus (cos. suff. 117) —or following an inheritance from this man with the condicio nominis ferendi-at the start of the Burnum inscription he was styled $[$ Cn. $(=$ Gnaeo $)]$ Minicio Faustino $[[u l i] o[\ldots f]$

die Vorgeschichte der Partherkriegs unter Marc Aurel und Lucius Verus', in R. Haensch and J. Heinrichs, eds., Herrschen und Verwalten. Der Alltag der römischen Administration in der Hohen Kaiserzeit. Kölner Historische Abhandlungen 46 (Köln and Weimar), 160-172, at 161-172. This action by Proculus was previously dated to a much earlier point in the reign.

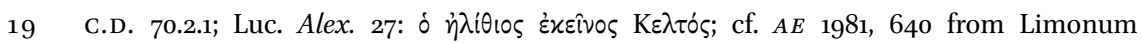
Pictavorum, clearly his home town. See on his career esp. I. Piso, Fasti Provinciae Daciae I. Die senatorischen Amtsträger (Bonn 1993), 61-65, with addenda and corrigenda in idem, Fasti Provinciae Daciae I. Die ritterlichen Amtsträger (Bonn 2013), 35-37. Severianus had governed Dacia superior from AD 150 or 151 to 153 . 
il(io) Serg(ia) Severo: "To Gnaeus Minicius Faustinus Julius, son of [Sextus?], (in the) Sergia (voting-district), Severus."21

His special appointment to Judaea is specifically registered in a fragment from Dio: "Then indeed Hadrian sent his best generals against them, foremost among whom was Julius Severus, who was dispatched from Britain, of which he was governor, against the Jews." ${ }^{22}$

This is not the place to discuss the man's earlier career in detail, although it is remarkable in many ways. ${ }^{23}$ The present paper concerns his transfer from Britain to Judaea. His dates can now be refined in the light of two new diplomas: one shows him already governor of Britain in AD 130, the other reveals that he was still there on 9 December $132 .{ }^{24}$

Sextus Julius Severus seems to have taken at least two equestrian officers with him from Britain to Judaea. Three or four centurions may also be supposed to have transferred with him at this time. But before discussing these cases, it should be noted that he may have taken with him to Judaea a whole legion, IX Hispana, although it is uncertain whether it was still in Britain when he was governing the province. IX Hispana was once thought to have been destroyed in Britain early in Hadrian's reign, when there were certainly heavy Roman losses there. ${ }^{25}$ But consideration of the careers of several of its officers has made this hardly plausible: there are three former tribuni laticlavii whose service in it should be significantly later than the years 117-119, and a legate $\mathrm{L}$. Aninius Sextius Florentinus, who, after commanding IX Hispana, became proconsul of Narbonensis, then governor of Arabia, where he is attested in 127, so is unlikely to have left the legion much before $124 .{ }^{26}$ This leaves unresolved the moment of the legion's own departure from Britain. Its latest datable record

21 CIL 3. $2830=9891=I L S$ 1056. O. Salomies, Adoptive and Polyonymous Nomenclature in the Roman Empire (Helsinki 1992), 126, n. 108, convincingly argues that Sex(to), his original praenomen, although generally restored after Faustino, would have been omitted here. His filiation at this time remains uncertain.

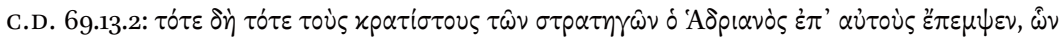

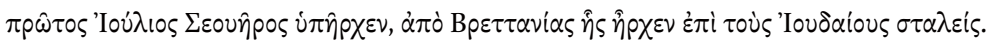

23 See especially Piso 1993, op. cit. (n. 19), 42-4, updated in idem 2013, op. cit. (n. 19), 24-29; A.R. Birley 2005, op. cit.(n. 15), 129-132; see Eck this volume 109-110.

$A E$ 2006, 1836; 2010, 1856. The second one gives Hadrian the title proco $(n) s(u l)$. This indicates that the emperor had delayed his return to Italy until 133 because of the Jewish uprising and - what has often been denied — that he actually spent some time at the front.

25 See e.g. A.R. Birley, 'A new tombstone from Vindolanda', Britannia 29 (1998), 299-306.

26 For the tribunes, A.R. Birley 2005, op. cit. (n. 15), 286-7, 256-7; for the legate, 244. 
there is an inscription of AD 108 at York. ${ }^{27}$ Its whereabouts thereafter are uncertain, but it could have been taken to the east initially to fight in the Jewish war, from 133 to 136, after which it could have been transferred to Cappadocia. A possible date for that (final) move is AD 137. Even if no further trouble was expected from the Alani, against whose threatening movements the historian Arrian (Flavius Arrianus) had been active as governor of Cappadocia in 135, as his Ektaxis set out in detail, he could well have urged Hadrian to reinforce the province. ${ }^{28}$ The disappearance of IX Hispana could then conjecturally be assigned to the disaster at Elegeia in 161, when, as mentioned above, an unnamed legion of the Cappadocian army was destroyed with all its officers, and the governor Sedatius Severianus took his own life. ${ }^{29}$

As the Burnum inscription shows, Sextus Julius Severus conducted the campaign with success, receiving the highest military honours open to a senator, the ornamenta triumphalia. Dio's account, preserved in epitome, ${ }^{30}$ gives some details of his operations. He suppressed the rebels with relentless efficiency, picking them off in small groups. He destroyed "fifty of the Jews' most important outposts and 985 of their most famous villages"; and 580,000 men are said to have been killed on the Jewish side. Dio does not record Roman casualties, which were substantial. ${ }^{31}$

Among those who served under him one may note three future governors of Britain: Q. Lollius Urbicus, legatus imp(eratoris) Hadriani in expedition(e) Iudaica, who may be regarded as the general's 'chief of staff'; probably the general's son Cn. Julius Verus as tribunus laticlavius of X Fretensis; and M. Statius Priscus, then just prefect of a cohort. ${ }^{32}$ Sextus Julius Severus no doubt remained

$27 \quad$ RIB 665.

28 On Arrian's career still instructive is R. Syme, 'The career of Arrian', Harvard Studies in Classical Philology 86 (1982), 181-212, repr. in idem, Roman Papers 4 (Oxford, 1988), 21-49, esp. 200-202 $=38-40$.

29 IX Hispana is omitted from the register of legions drawn up not long before c. 165, ILS 2288, Rome. On its possible history under Hadrian and later, A.R. Birley 2005, op. cit. (n. 15), 228-9, with detailed references to earlier discussions. The identification of the unnamed legion with IX Hispana is approved by Piso 1993, op. cit. (n. 19) 64 with his n. 15 .

30 C.D. 69.13.3-14.1.

31 W. Eck, 'The Bar Kokhba revolt: the Roman point of view', Journal of Roman Studies 89 (1999), 76-89, underlines the seriousness of the war for Rome and of Rome's losses, including not only the legio XXII Deiotariana but numerous auxiliary units. See further, among his numerous important contributions on this subject, W. Eck, 'Der Bar Kochba Aufstand der Jahre 132-136 und seine Folgen für die Provinz Judaea/Syria Palaestina', in G. Urso, ed., Iudaea Socia-Iudaea Capta (Milan 2012), 249-265.

A.R. Birley 2005, op. cit. (n. 15), 136-140; 145-9; 151-5. 
in Judaea until the war was ended, in $136 .{ }^{33} \mathrm{He}$ was then apparently appointed to yet another governorship, of Syria, although this has been doubted; if it is accepted, this is further evidence for the satisfaction with which Hadrian regarded him. ${ }^{34}$ At all events, the distinguished career in the emperors' service of his son Julius Verus, indicates that imperial favour for this family of colonial Romans continued into the next two reigns. ${ }^{35}$

As for the men whom Sextus Julius Severus probably took with him from Britain to Judaea, to start with one may discuss two equestrians. The first was the future great commander of the $160 \mathrm{~s}$, M. Statius Priscus Licinius Italicus (cos. ord. 159), in the early 13os still only a Roman knight, in his prima militia as prefect of a cohort. For convenience the inscription setting out his complete career in descending order, may be cited here, as the later stages will be discussed in the second part of this paper:

[M(arco) Stati]o M(arci) f(ilio) Cl(audia) Prisco [L]icinio Italico, leg(ato) Augustorum $\operatorname{pr}(\mathrm{o}) \operatorname{pr}($ aetore $) \operatorname{prov}($ inciae) Cappadociae, leg(ato) Aug[g.=Augustorum duorum)] pr(o) pr(aetore) prov(inciae) Brittanniae, $\operatorname{leg}$ (ato) $\operatorname{Aug}[\mathrm{g} .=$ Augustorum duorum) $] \operatorname{pr}(\mathrm{o}) \operatorname{pr}$ (aetore) $\operatorname{prov}($ inciae $)$ Moesiae super(ioris), curato[ri] alvei Tiberis et cl[o]acarum urbis, c[o(n)s(uli)], leg(ato) Aug(usti) prov(inciae) Daciae, leg(ato) leg(ionis) XIII G(eminae) p(iae) f(idelis), leg(ato) leg(ionis) [X]IIII Gem(inae) Martiae Victricis, sacerdoti Titiali [Fl]aviali, pr(aetori) inter cives et peregrinos, $\operatorname{tr}(\mathrm{ibuno}) \mathrm{pl}(\mathrm{ebis})$, quaes[t(ori)], proc(uratori) Aug(usti) XX (Vicesimae) hereditatium prov(inciarum) Narbone(n)s(is) et Aquita[n(iae), p]r(aefecto) eq(uitum) alae I pr(aetoriae) c(ivium) $\mathrm{R}$ (omanorum), $\operatorname{tr}$ (ibuno) mil(itum) leg(ionis) I Adiutr(icis) p(iae) f(idelis) et leg(ionis) X [G(eminae)] p(iae)[f(idelis) e]t leg(ionis) IIII (sic: a mistake for III) Gallicae, praef(ecto) coh(ortis) IIII Lingonum, vexillo mi[l(itari) d]onato a divo Hadriano in expeditione Iudaic[a], Q(uintus) Cassius Domitius Palumbus.

33 For the date, $\mathrm{AD} 136$, rather than 135 as previously thought, see W. Eck 1999, op. cit. (n. 31).

34 Attested only by $I L S$ 1056; omitted in $P^{2} R^{2} \mathrm{~J} 576$; accepted by E. Dąbrowa, The Governors of Roman Syria from Augustus to Septimius Severus (Bonn 1998), 96. Werner Eck, as he kindly tells me, regards the governorship of Syria as non-existent, resulting from a confusion caused by the renaming of Judaea as Syria Palaestina after the war ended.

35 A.R. Birley 2005, op. cit. (n. 15), 145-9: after active service under Antoninus Pius, he was prominent under Marcus, both in the Parthian war of the 160 and the Marcomannic war of the 170s; he died in 179, having been designated to a second consulship, as ordinarius, for 180 . 
(In honour of) Marcus Statius, son of Marcus, (in the) Claudia (votingdistrict), Priscus Licinius Italicus, propraetorian legate of the emperors of the province Cappadocia, propraetorian legate of the two emperors of the province Brittannia, propraetorian legate of the two emperors of the province Moesia superior, curator of the bed of the Tiber and of the sewers of the City, consul, propraetorian legate of the emperor of the province Dacia, legate of the legion XIII Gemina Pia Fidelis, legate of the legion XIIII Gemina Martia Victrix, Titial Flavial priest, praetor (dealing with disputes) between citizens and foreigners, tribune of the plebs, quaestor, procurator of the emperor for the five per cent inheritance tax in the provinces of Narbonensis and Aquitania, prefect of cavalry of the Ala I Praetoria, military tribune of the Legion I Adiutrix Pia Fidelis and of the Legion X Gemina Pia Fidelis and of the Legion IIII [sic: a mistake for III] Gallica, prefect of the Cohors IIII Lingonum, decorated with a military flag by the Deified Hadrian in the Jewish expedition, (set up by) Quintus Cassius Domitius Palumbus. ${ }^{36}$

The inscription gives Priscus' first post as prefect of the Fourth Cohort of Lingones, known to have been stationed in Britain, ${ }^{37}$ and registers that for service 'in the Jewish expedition' he received a decoration from Hadrian. He did not necessarily take his cohort to Judaea; more likely Sextus Julius Severus had him promoted to the militia secunda, first as tribune in the Syrian legion III Gallica, which took part in the war; Priscus probably held his second tribunate in a detachment of the Upper Pannonian legion X Gemina, which had been brought to Judaea by Sextus Attius Senecio. Since the third tribunate that followed was in another legion of Pannonia superior, it may be conjectured that he returned to that province with $X$ Gemina and was retained there, as tribune of I Adiutrix. ${ }^{38}$ After these three tribunates he finally entered the third

$36 \quad$ CIL 6. $1523=I L S$ 1092, Rome.

37 P.A. Holder, The Roman Army in Britain (London 1982), 119; M.G. Jarrett, 'Non-legionary troops in Britain: part one, the units', Britannia 25 (1994), 35-71, at 62, adding that "nothing suggests that he took the cohort [sc. to Judaea] with him." Contrast S. Applebaum, Prolegomena to the Study of the Second Jewish Revolt (Oxford 1976), 44-49; cf. his Appendix, 65-69, listing 24 cohorts and 8 alae which "served, or probably served in Hadrian's Jewish war", an interesting attempt, naturally requiring fundamental revision in the light of all the new diploma evidence.

38 H.-G. Pflaum, Les carrières procuratoriennes équestres sous le Haut-Empire romain (Paris 1960-1), hereafter cited as $C P$, no. 136, assumed that his tribunates of I Adiutrix and $X$ Gemina were the first two that he held and that they were both served in those legions' home province, Pannonia superior. Piso 1993, op. cit. (n. 19), 69 and n. 4, accepts that his 
militia, as prefect of an ala. This regiment, the Ala I Praetoria, was stationed in Pannonia inferior, at Teutoburgium, just beyond the confluence of the Dravus with the Danube. After this Priscus went on to a brief procuratorial career, with a rather lowly post, and then entry to the senate as quaestor. ${ }^{39}$ It is worth noting that his progress as a senator was very slow for the next two decades and it was only in the late 15 os that his career suddenly became spectacular, see below.

The second case of a man of equestrian rank evidently taken to Judaea, probably at this time, is conjectural. It concerns Marcus Censorius [C]ornelianus, known only from an altar he dedicated to Iuppiter Augustus at the fort of Maryport on the north-west coast of England:

Iovi Aug(usto) $\mathrm{M}$ (arcus) Censorius $\mathrm{M}$ (arci) fil(ius) Voltinia [C]ornelianus 7 (centurio) leg(ionis) [X Fr] etensis prae[fec]tus coh(ortis) I Hisp(anorum) ex provincia Narbone[n(si)] domo Nemauso [v.]s.l.m.

To August Juppiter, Marcus Censorius, son of Marcus, (in the) Voltinia (voting-district), Cornelianus, centurion of the Legion XFretensis, prefect of the First Cohort of Hispani, from the province Narbonensis, his home Nemausus, paid his vow willingly and deservedly. ${ }^{40}$

On this interpretation the equestrian officer, whose presence at Maryport can confidently be dated to Hadrian's reign, accepted a centurionate in the Jerusalem legion, prima facie a downgrading, but in fact a career move for which there are plenty of parallels. Whether he took part of the Cohors I Hispanorum with him is uncertain. ${ }^{41}$

first tribunate was in III Gallica, but assumes that his service in both the other two legions was in their home province. For the order proposed above, see Devijver, $P M E \mathrm{~S} 78$. Sextus Attius Senecio, tribune of $X$ Gemina, was "sent on the Jewish expedition by the deified Hadrian", with a detachment ( $C I L$ 6. 3505; PME A 188). On this interpretation, Statius Priscus' decoration, a vexillum, was gained for service as tribune, which would not usually have been sufficient for this rank, but it was in line with Hadrian's practice: see e.g. V.A. Maxfield, The Military Decorations of the Roman Army (London 1981), 176-7.

39 Pflaum, $C P$ no. 136, located the ala in Cappadocia, followed by Devijver, $P M E S$ 78, and others, including A.R. Birley 2005, op. cit. (n. 15), 153 and $P I R^{2}$ S 880 (published in 2006). It is corrected in PME 4 Supp. 1, p. 1726; see esp. B. Lörincz, Die römischen Hilfstruppen in Pannonien während der Kaiserzeit (Wien 2001), 206 and for Teutoburgium ibidem, 26.

$40 \quad$ RIB 814.

41 Jarrett 1994, op. cit. (n. 37), 47; PME C 106; D.J. Breeze, 'The regiments stationed at Maryport and their commanders', in R.J.A. Wilson, ed., Roman Maryport and its Setting. 
One may also postulate three or perhaps four centurions whose careers suggest that they went from Britain to Judaea at this time with Sextus Julius Severus:

1. Quintus Albius Felix, who served in the British legion $X X$ Valeria Victrix, was decorated by Hadrian, surely for service in the Jewish War:

Q(uinto) Albio Q(uinti) f(ilio) Hor(atia) Felici, 7 (centurioni) leg(ionis) $\mathrm{XX} \mathrm{V(aleriae)} \mathrm{V(ictricis),} \mathrm{corniculario} \mathrm{pr(aefecti)} \mathrm{pr(aetorio),} \mathrm{donis}$ donato ab divo Traiano Aug(usto) torquibus armillis phaleris bello Parthico et ab imp(eratore) Caesare Traiano Hadriano Aug(usto) hasta pura et corona aurea. ${ }^{42}$

To Quintus Albius, son of Quintus, (in the) Horatia (voting-district), Felix, centurion of the Legion XX Valeria Victrix, adjutant of the Praetorian Prefect, decorated by the Deified Traianus with torques, arm-bands, discs in the Parthian War and by the Emperor Caesar Traianus Hadrianus with a pure spear and a gold crown.

2. Pon(...) Magnus is recorded from Hadrian's Wall sector 46-46b, in charge of a building party: [co]h(ortis) II 7 (centuria) Pon(...) Magni, datable a fortiori to the $120{ }^{43} \mathrm{He}$ is very likely the same man as Pontienus Magnus, chief centurion, $p$ (rimus) $p$ (ilus), of $X$ Fretensis in $\mathrm{AD} 150 .{ }^{44}$ One may infer that he was

Essays in Memory of Michael G. Jarrett (Kendal 1997), 67-89, at 73-75. For a quite different view, cf. E. Birley, 'A Roman altar from Old Kilpatrick and interim commanders of auxiliary units', Latomus 42 (1983) 73-83, at 78 , repr. in idem 1988, op. cit. (n. 13), 221-31, at 226 , reading prae [posi] tus rather than prae [fec]tus: "(...) it is at least possible that the centurion in question, $\mathrm{M}$. Censorius Cornelianus, had come to Britain with a vexillation of X Fretensis, sent by Hadrian from Judaea expeditione Britannica (...) and he will, in that case, have been acting commander of the cohort." But this interpretation depends on E. Birley's frequently argued dating of the Hadrianic expeditio Brittannica to a later moment in Hadrian's reign, rather than to the time of Hadrian's own visit, sc. in AD 122: see now A.R. Birley 2014, op. cit. (n. 1), at 243-253, arguing that the expeditio must be dated to 122 , citing in particular M.G. Jarrett, 'An unnecessary war', Britannia 7 (1976), 145-151, R. Syme, 'Journeys of Hadrian', Zeitschrift für Papyrologie und Epigraphik 73 (1988) 159-170, at 165, repr. in idem, Roman Papers 6 (Oxford 1991), 346-57, at 353-4; and V. Rosenberger, Bella et expeditiones. Die antike Terminologie der Kriege Roms (Stuttgart 1992), passim. CIL 11. 3108. See Maxfield 1981, op. cit. (n. 38), 194-6.

$43 \quad$ RIB $1845+$ add.

$44 \quad C I L 16$ App., no. 13; CPL no. 117, A 13 and B 9. 
taken to Judaea by Sextus Julius Severus, remained there, and was transferred to $X$ Fretensis, eventually becoming chief centurion of that legion.

3. Gaius Ligustinius Disertus:

C. (=Gaio) Ligustinio C. (=Gai) f(ilio) Clu(stumina) Diserto 7 (centurioni) leg(ionis) XX V(aleriae) V(ictricis), 7 (centurioni) leg(ionis) IIII Scyth(icae), item 7 (centurioni) leg(ionis) XX V(aleriae) V(ictricis) evocato Aug(usti), benef(iciario) praef(ecti) praet(orio) Eutyches lib(ertus) patrono optimo ob merita cuius dedicatione decurionib(us) et plebei crus $[\mathrm{tu}]$ lum et mulsum dedit. ${ }^{45}$

(In honour of) Gaius Ligustinius, son of Gaius, (in the) Clustumina (voting-district), Disertus, centurion of the Legion XX Valeria Victrix, centurion of the Legion IIII Scythica, likewise centurion of the Legion XX Valeria Victrix, retained in service by the Emperor, special duties man of the praetorian prefect, Eutyches (his) freedman (set this up) for his best of patrons on account of his deserts; on the occasion of the dedication he gave the decurions and plebs little cakes and honey-flavoured wine.

This man, after a full term (sixteen years) in the Praetorian Guard, during which he was a beneficiarius, 'special duties man', of the Prefect, had been invited to continue in the army as an evocatus Augusti, 'soldier retained in service by the Emperor. He was then made a legionary centurion. ${ }^{46}$ His career in this rank consisted solely of two terms with the British legion XX Valeria Victrix, interrupted by a commission in IV Scythica of the army of Syria. One may infer that his temporary move to the east could have been with Sextus Julius Severus (his cognomen meaning 'eloquent' is seemingly unique). ${ }^{47}$

45 CIL 11. 5960, Pitinum Mergens.

46 Disertus' origin at Pitinum Mergens was shared by a prefect of a cohort who served under the Hadrianic governor of Britain, L. Trebius Germanus, in office on 20 August AD 127: RMD 4. 240 is a diploma issued to a veteran coh(ortis) II Lingon(um), cui prae(e)st C. Hedius Verus Pitino Merg(ente). Hedius Verus (PME H 2, with only a cross-reference to Devijver 1975 (op. cit. n. 11), no. 55) was later military tribune in the legion II Traiana fortis in Egypt and prefect of the Ala Indiana in Germania superior, as shown by CIL 11. 6123 , a statue-base at Forum Sempronii, of which he was patron. For the governor Trebius Germanus, see A.R. Birley 2005 (op. cit. n. 15) 125-129. One may speculate that it was he who appointed both men to posts in Britain.

47 See E. Birley, 'Promotions and transfers in the Roman Army II: the centurionate', Carnuntum Jahrbuch 1963-1964 (Wien 1965), 21-33, at 29f., repr. with some revision in idem 1988, op. cit. (n. 13), 206-20, at 216, accepted hesitantly by Maxfield 1981, op. cit. 
4. T. Quintius Petrullus. A partly preserved tombstone from Bostra in the province of Arabia commemorates a centurion of the Bostra legion III Cyrenaica, who died at the age of thirty and whose origin is registered as Britannia:

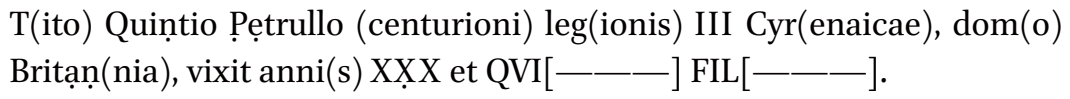

For Titus Quintius Petrullus, centurion of Legio III Cyrenaica, from Britain, who lived 30 years and.... ${ }^{48}$

In a forthcoming article three colleagues have plausibly suggested that Sextus Julius Severus' transfer from Britain to take command against Bar-Kochba could have been the occasion for Petrullus' becoming a centurion in Arabia. ${ }^{49}$ Of course, as they recognise, this can only be conjectural. One might note as a refinement the possibility that Petrullus came to the east as a soldier in the Ninth legion, if, as suggested above, it was brought to Judaea by Sextus Julius Severus, and that he was then offered a commission in III Cyrenaica. ${ }^{50}$

As a postscript on centurions, one may note that in contrast to the paucity of Greek cognomina among the Hadrianic centurions from the centurial stones along Hadrian's Wall, three of the Antonine centurions in Scotland have them: Sta(tilius?) Telesphorus, at Carriden, ${ }^{51}$ Antonius Aratus at Castlecary, ${ }^{52}$ and Glicon at Croy Hill. ${ }^{33}$ (The latter might of course be an officer in an auxiliary cohort.) It may be no more than coincidence, but if an explanation is required

(n. 38), 195-6. It need hardly be repeated that I respectfully reject E. Birley's frequently expressed theory, here in connection with Disertus, that there was "warfare again in Britain during the closing years of the reign". See $n .1$ above.

48 IGLS 13.1.9188+ add. (IGLS 13.2.9188), with H. Solin, 'Analecta epigraphica CCLXXXVCCXCI', Arctos 47 (2013), 265-300, at 281, cf. 275-6, who corrected the reading of the name. (It is not clear whether what follows et is qui or perhaps the start of a name).

49 L.E. Tacoma, T. Ivleva and D.J. Breeze, 'Lost along the way: a centurion domo Britannia in Bostra', Britannia 47 (2016), forthcoming. I am very grateful to the editor of Britannia, Professor Barry Burnham, and to the authors for allowing me to see their paper before publication and to cite it here.

$5^{0}$ One could also speculate that Petrullus had been offered a commission in III Cyrenaica before this, by L. Aninius Sextius Florentinus, the former legate of IX Hispana, when he became legate of Arabia (above, with n. 26), supposing that the legion had still been in Britain when Florentinus commanded it.

$51 \quad$ RIB 2138.

$5^{2} \quad R I B 2156$.

$53 \quad R I B 2164$. 
one might propose that on his move from Britain to Judaea Sextus Julius Severus may have taken not only a few officers from but whole units or detachments - the possible transfer of the legion IX Hispana has already been mentioned. Those units or detachments that later returned to Britain may have picked up new officers in the east, who came to Britain with them. Of course, Greek names do not always mean eastern origin. But for centurions in western legions this seems plausible.

For the transfer of a regiment from the Danube to the east under Hadrian, note the movement of coh(ors) I Claudia Sugambrorum veterana equitata from Moesia inferior to Eumeneia in Asia:

[....] divi Nervae nepotis Traiani Hadriani Aug(usti) domuique eiius senatui populiq(ue) $\mathrm{R}$ (omani) coh(ors) I Cl(audia) Sugambrum veteranae equitatae $\mathrm{M}$ (arcus) Iulius $\mathrm{M}$ (arci) f(ilius) Fab(ia) Pisonianus qui et Dion praef(ectus) fabrum et praef(ectus) coh(ortis) s(upra) s(criptae) domo Tyro metropolis Phoenices et Coeles Syriae qui a Moesia inf(eriore) Montan(a) praesidio numerum in Asia(m) perduxit v(otum) s(olvit) $\mathrm{l}$ (ibens) $\mathrm{m}$ (erito)

(In honour of the Emperor Caesar, son of the Deified Trajan), grandson of the Deified Nerva, Traianus Hadrianus Augustus, and his house and the senate and people of Rome, the First Claudian Cohort of Sugambrians, the Veteran one, part-mounted, (set this up). Marcus Julius son of Marcus, (in the) Fabia (voting-district), Pisonianus, who is also (called) Dion, Prefect of Engineers and Prefect of the above named Cohort, his home being Tyrus, the mother-city of Phoenice and Coele Syria, who led the unit from Moesia inferior from the station of Montana into Asia, fulfilled his vow willingly and deservedly. ${ }^{54}$

Eumeneia was probably just an intermediate stop—on the way to Judaea? (cos. ord. 159)

Priscus' early career has already been discussed in connection with Hadrian's Jewish War. Here, we may take a brief look at its later stages. His governorship of Dacia superior, attested by eight inscriptions in the province, as well as by 
his inscription at Rome, immediately preceded his consulship in 159. It is dated closely by diplomas, to 13 December 156 and 8 July 158 ; a dedication made at Apulum sub M. Statio Prisco consule designato can be assigned to autumn 158. Before that he had commanded the Carnuntum legion XIV Gemina, perhaps when Claudius Maximus, the friend of Marcus Aurelius, was governing Upper Pannonia (he is attested there in 150 and 154). Priscus' consulship as ordinarius for 159 was a remarkable honour for a novus homo - only one other man of comparable background, the great jurist Salvius Julianus, received similar distinction during this reign (he was consul ordinarius in AD 148). The obvious reason in Priscus' case was his military success in Dacia, presumably in fighting against free Dacians and Jazyges, as revealed by inscriptions from that province. ${ }^{55}$ It is worth asking whether the sudden rise in Priscus' fortunes, after his slow progress during most of the reign of Antoninus Pius, was the result of the change in the prefecture of the praetorian guard: M. Gavius Maximus, vir severissimus, died in AD 156 or 157 after nearly twenty years in that post, in which he doubtless exercised great influence on military appointments. ${ }^{56}$ After Priscus' consulship he was briefly Tiber curator, but before the end of 160 must have become governor of Moesia superior, where he is attested in office on 8 February 161. It may have seemed a good idea to put him back close to the region where he had won his victories in AD 158 . He was still there, not surprisingly, after the death of Pius in the following month, as shown by his dedication in honour of Marcus and Lucius Verus, set up after he had been appointed to Britain. It may have been the sudden death of a recently appointed governor of

$55 C I L$ 3. $1416=I D R$ 3. 3, 276, Sub Cununi, is a dedication by Priscus to Victoria Augusta, and the inscription from Apulum cited in the previous note was made "for the safety of the Roman Empire and the courage of the legion XIII Gemina under Marcus Statius Priscus, consul designate." Cf. $C I L$ 3. $1061=I L S 4006=I D R$ 3. 5, 185, Apulum. On his governorship of Dacia superior see Piso 1993, op. cit. (n. 19), at 7of., properly dismissing arguments from the wording of $I L S 1092$ that the governorship and command of the legion were separate. As he recognises, Piso 2013, op. cit. (n. 19) 36, the troops from Africa and Mauretania listed in the diploma of AD 158, CIL 16.108, can no longer be used as evidence for serious fighting under Priscus (as he had argued in 1993, 70 with n. 16, following earlier scholars), as they are now known to have been there earlier, citing $A E$ 2007, 1763 of AD 152. Indeed (as Paul Holder kindly points out) another new diploma shows that they were already there in AD 146: W. Eck and A. Pangerl, 'Zwei neue Diplome für die Truppen von Dacia Superior und Dacia Porolissensis', Zeitschrift für Papyrologie und Epigraphik 191 (2014) 269-277, at 271. The reason for this transfer remains uncertain.

56 On Gavius and his successors: HA, Antoninus Pius 8.7-9. See Pflaum, $C P$ no. 105 + Supp. pp. 32f., and no. 138. In particular, the entry into office of T. Furius Victorinus as prefect of the guard in AD 160, $C P$ no. 139, may have been decisive for Priscus' consular appointments. 
Britain, or perhaps just the difficult military situation in the north of that province, that led the new co-emperors to transfer Priscus there soon after their accession. As stated by the Historia Augusta: "a British war was also threatening" at that time, which as it turned out had to be dealt with by Priscus' successor Sextus Calpurnius Agricola (cos. suff. 154$){ }^{57}$

Priscus can only have spent some months at the most in Britain when a more serious situation arose in the east: a Parthian attempt to take control of Armenia, resulting in the defeat and suicide of the governor of Cappadocia, with the loss of a legion - perhaps it was IX Hispana (cf. above)—, then the Parthian invasion of Syria. Priscus was chosen to deal with this crisis, and won a major victory, capturing the Armenian capital Artaxata, ${ }^{58}$ and founding a new one, which he garrisoned. ${ }^{59}$ These successes allowed Verus, who had gone east in 162 as nominal commander-in-chief, to assume the title Armeniacus in 163. Lucian alleges that a contemporary historian described "how Priscus the general merely shouted out and twenty-seven of the enemy dropped dead."60 Hardly serious evidence, but perhaps Priscus had an aggressive style of leadership. The decision to summon Priscus from Britain to deal with a crisis in the east exactly parallels the sending of Sextus Julius Severus to Judaea a generation earlier. Severus was described as "the foremost of Hadrian's leading generals" in that connection. ${ }^{61}$ Priscus, after his success in Dacia in the late $150 \mathrm{os}$, was no doubt equally highly rated. These two cases underline the high military status of Dacia and of Britain and their governors.

A rash previous speculation about Priscus' origin was that he might have come from the colonia of Camulodunum, Colchester in Britain; others had proposed Dalmatia or north-east Italy as his home. ${ }^{62}$ Now a newly discovered inscription, from Teanum Sidicinum, published in exemplary fashion by Giuseppe

HA, M. Ant. Phil. 8.7: imminebat etiam Brittanicum bellum. See A.R. Birley 2005, op. cit. (n. 15), 151-5 on Priscus; 155-7 on Agricola.

$58 \quad$ HA, M. Ant. Phil. 9.1, cf. Verus 7.1.

59 C.D. $71 \cdot 3 \cdot 1^{1}$.

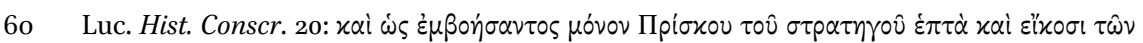
$\pi \circ \lambda \varepsilon \mu i \omega \nu$ ह่ $\xi^{\prime} \dot{\theta} \theta \alpha \nu \nu$.

61 C.D. 69.13.2, cited above, at n. 22.

62 Colchester: A.R. Birley 2005, op. cit. (n. 15), 152-3, with arguments rightly described as "un po' poco per fare di lui in pratica l'unico senatore romano di quella provincia," by G. Camodeca, 'Fufidia Clementiana, c(larissima) p(uella), e i suoi avi consolari in una nuova iscrizione da Teanum del tempo di M. Aurelio', Zeitschrift für Papyrologie und Epigraphik 179 (2011), 231-8 at 234-5. Cf. Alföldy 1977, op. cit. (n. 15), 314, suggesting Dalmatia, and for north-east Italy Piso 1993, op. cit. (n. 19), 73. 
Camodeca, has produced a rich harvest of prosopographical links-and a far likelier patria for the Statii, Luceria in Apulia. The text may be cited here:

Fufidiae Clemẹntianae, c(larissimae) p(uellae), L(uci) Fufidi Pol[1]ionis, c(larissimi) i(uvenis) fil(iae), L(uci) Fufidi Pollionis, co(n)sulis), nẹp(ti), Sex(ti) Corneli Clementis, co(n)s(ulis) ṇẹp(ti), M(arci) Stati Prisci, ducis eț co(n)s(ulis) prr[on(epti)], Cạpitolinus [se]r(vus) act(or).

(In honour of) Fufidia Clementiana, girl of senatorial rank, daughter of Lucius Fufidius Pollio, young man of senatorial rank, granddaughter of Lucius Fufidius Pollio, consul, granddaughter of Sextus Cornelius Clemens, consul, great-granddaughter of Marcus Statius Priscus, general and consul, Capitolinus, (her) slave agent (set this up).

This is engraved on a statue-base in honour of Priscus' great-granddaughter, Fufidia Clementiana, c(larissima) $p$ (uella), and names, as well as Priscus, described as ducis et cos., her father, L. Fufidius Pollio, c(larissimus) i(uvenis), her paternal grandfather, L. Fufidius Pollio (cos. ord. 166) and her maternal grandfather Sex. Cornelius Clemens (cos. suff. in the 16os). For the full discussion one must refer to Camodeca's paper. ${ }^{63}$ Here one may simply mention a few key points. Statius Priscus' son-in-law Fufidius Pollio, who served as legate of Galatia, clearly while Priscus was winning his victory in the adjacent Cappadocia and Armenia, no doubt owed his previously unexplained honour of being made consul ordinarius ${ }^{64}$ to his relationship to the great general. Since Priscus is not heard of again after his victory in AD 163, it may be that he died before the war ended. Perhaps the honour for his son-in-law was a way for the emperors to make up for the decorations which Priscus would have received at the triumph in October 166, had he lived. Further, the status of Cornelius Clemens in the family tree was clearly that of father-in-law of the younger Pollio, whose wife was probably called Cornelia Clementiana, as Camodeca infers from the name of the child honoured at Teanum. Clemens became governor of the III Daciae in AD 170, at a critical moment in the Marcomannic wars, following the death of M. Claudius Fronto (cos. suff. 165?), "fighting bravely for the commonwealth until the last", ad postremum pro $r(e) p($ ublica $)$ fortiter

63 Camodeca 2011, op. cit. (n. 62), passim. The inscription is reproduced as $A E 2011,271$.

64 Cf. Camodeca 2011, op. cit. (n. 62), 235-6, who cites Alföldy 1977, op. cit. (n. 15), 101ff., pointing out that the only other coss. ord. under Antoninus Pius and Marcus Aurelius not known to have come from consular families were the famous jurist P. Salvius Julianus (cos. ord. 148) —and Statius Priscus (cf. above). 
pugnans. ${ }^{65}$ Regarding the date of the dedication, one might suggest that the younger L. Fufidius Pollio was no longer alive at the time. He could well have died before he could enter the senate-perhaps a victim of the plague which was brought to Rome by the returning troops in 166 - and hence could only be called $c$ (larissimus) $i$ (uvenis). In that case, his daughter Clementiana was not necessarily just a child at the time of the dedication; although, as no husband is named, she was no doubt unmarried. Camodeca also draws attention to Fufidia Pollitta, probably an older sister of Fufidia Clementiana: Pollitta and her husband C. Caerellius Sabinus (cos. suff. ca. 190), are attested by several dedications in Dacia, where Sabinus was legate of legion XIII Gemina, based at Apulum. ${ }^{66}$ All in all, the Teanum inscription has thrown valuable light on the composition of the Roman high command at a critical time. ${ }^{67}$

As for the theme of this paper, it must be admitted that there is no hard evidence for men taken by Statius Priscus to Cappadocia. But there are a few possibilities. First, there is the remarkable M. Valerius Maximianus, whose career was made widely known by the statue-base in his honour found at Diana Veteranorum in Numidia. Here only the first few appointments require detailed comment. For convenience his career down to AD 175 is set out:

$\mathrm{M}(\operatorname{arco})$ Valerio Maximiano ... equo p(ublico), praef(ecto) $\operatorname{coh}($ ortis) I Thrac(um), trib(uno) coh(ortis) I (H)amiorum civium $\mathrm{R}$ (omanorum), praep(osito) orae gentium Ponti Polemoniani, don(is) don(ato) bello Phart(ico), allect(o) ab imp(eratore) $\mathrm{M}(\operatorname{arco})$ Antonino Aug(usto) et misso in procinctu Germanic(ae) exped(itionis) ad deducend(a) per

$65 C I L$ 6. $1377=31640=I L S$ 1098. See Piso 1993, op. cit. (n. 19), 94-102, and idem 2013, op. cit. (n. 19), 37-9, on Claudius Fronto, and 103-105, on Clemens.

66 See Piso 1993, op. cit. (n. 19), 235-7. The couple's dedication at Apulum to Iunoni Reginae Populoniae, deae patriae, CIL 3. $1075=I L S 3087=I D R$ 3.5, 107, coupled with Caerellius' tribe Oufentina, known from their son, C. Caerellius Fufidius Annius Ravus C. fil. Ouf. Pollittianus, $I L S$ 1160-1, had already pointed to Aquinum as his home town. The new inscription shows that his wife came from nearby Teanum: see Camodeca 2011, op. cit. (n. 62), 236-7.

67 The preceding remarks largely reproduce A.R. Birley 2014, op. cit. (n. 1), 255-8. One may still consult with profit R. Syme, 'Antonine government and governing class', Roman Papers 5 (Oxford 1988), 667-688, esp. 683-8. Note his suggestion, at 685, that as well as Statius Priscus "there was another ex-governor of Britain, Julius Verus, whom no literary source even names [who was] perhaps the chief architect of victory." Cn. Julius Verus (cos. c. 151, des. II 179) was governor of Syria in the early 160 s, his term of office probably beginning well before the only dated evidence, $I L S$ 5864, of AD 164: $P I R^{2} \mathrm{~J}$ 618; Dąbrowa 1998, op. cit. (n. 34), 110-12; A.R. Birley 2005, op. cit. (n. 15), 145-9. 
Danuvium quae in annonam Panno(niae) utriusq(ue) exercit(uum) denavigarent, praepos(ito) vexillationum clas(sium) praetor(iarum) Misenatis item Ravennatis item clas(sis) Britannic(ae) item equit(um) Afror(um) et Mauror(um) elector(um) ad curam explorationis Pannoniae, praef(ecto) al(ae) I Aravacor(um), in procinctu Germanico ab imp(eratore) Antonino Aug(usto) coram laudato et equo et phaleris et armis donato, quod manu sua ducem Naristarum Valaonem interemisset et in eade $(\mathrm{m})$ ala quartae militiae honor(em) adepto, praef(ecto) alae contar(iorum), don(is) don(ato) bello Ger(manico) Sar(matico), praep(osito) equitib(us) gent(ium) Marcomannor(um) Naristar(um) Quador(um) ad vindictam Orientalis motus pergentium, honor(e) centenariae dignitatis [AD 175].

To Marcus Valerius Maximianus ..., (holder of) the public horse, prefect of the First Cohort of Thracians, tribune of the First Cohort of Hamii, Roman citizens, put in charge of the coast of the people of Polemonian Pontus, decorated in the Parthian War; chosen by the Emperor Marcus Antoninus Augustus and sent to the front in the German expedition to conduct along the Danube (goods) that were to move downstream to supply the armies of both Pannonias, having been put in charge of detachments of the praetorian fleets of Misenum and Ravenna and of the Britannic fleet, also of selected African and Moorish cavalrymen with the task of reconnoitering Pannonia; prefect of the Ala I Aravacorum, publicly praised by the Emperor Antoninus Augustus and awarded both a horse and discs and weapons because he had killed with his own hand Valao the chief of the Naristae, and in the same Ala achieved the rank of the fourth militia; prefect of the Ala Contariorum, decorated in the German-Sarmatian war, put in charge of cavalrymen from the peoples of the Marcomanni, Naristae and Quadi proceeding to punish the rising in the east, with the rank of a centenary (procurator). ${ }^{68}$

Maximianus began as prefect of a cohors I Thracum, followed by the tribunate of cohors I (H)amiorum civium $R$ (omanorum). There were at least three if not four cohortes I Thracum, so the identity of the one commanded by Maximianus cannot be verified. H.-G. Pflaum took it to be the one in Cappadocia, and accepted a very dubious Trier inscription as evidence for a milliary cohors I

$68 A E$ 1956. 124. See especially Pflaum, $C P$, no. 181 bis; and now $P I R^{2} V_{125}$. The Orientalis motus refers to the rebellion of Avidius Cassius. 
Hamiorum in Syria. ${ }^{69}$ Eric Birley suggested that Maximianus' militia prima was as prefect of the cohors I Thracum that was based in Britain, further, that "when Statius Priscus moved from Britain to take command in Cappadocia he took Maximianus with him." He rejected Pflaum's acceptance of the sixteenth-century reading of $c I L 13 \cdot 3684$, Trier, restored as commemorating a former centurion "of the First Milliary Cohort of Hamae(i) in Syria", [co]hortis [ $p] r$ (imae) Hamae(orum) miliariae in Syria. He preferred to restore "from the First Milliary Cohort of Thracians in Syria", ex [co]hort [ I I Tr $]$ ha [c(um) milliaria in Syria in the Trier inscription and concluded that this unit was irrelevant for Maximianus, whose command in the militia secunda as trib(unus) coh(ortis) $I$ (H)amiorum civium $R$ (omanorum) he preferred to locate in Cappadocia, assuming that there was a milliary cohort of Hamii in that province. ${ }^{70}$

But perhaps Maximianus had actually commanded the cohors I Hamiorum which is attested in Britain. This is after all the only cohors I Hamiorum for whose existence there is clear evidence, if one discounts the unit supposedly attested by the lost Trier inscription. An objection is that the British cohort was not a cohors milliaria, whereas the one that Maximianus commanded as tribune should prima facie have been of that size. However, it is worth noting that another presumed commander of the British quingenary cohort, Marcus Caecilius Donatianus, was "by the emperor's favour serving as a tribune (although still) a prefect", militans tribunus in praefecto dono principis, as he expressed it in his famous poem honouring the Dea Syria at Carvoran. ${ }^{71}$ Perhaps Maximianus had the same privilege-just as later, when praefectus

$69 \quad C P$, no. 181 bis.

$70 \quad$ E. Birley, 'Pannonians in Roman Britain', Zeitschrift für Papyrologie und Epigraphik 73 (1988), 151-5. The Trier inscription is known only from the 17 th century text by the antiquary Christophorus Brouwer of Arnhem. It is restored in CIL as follows (preceded by the words 'fuit fere'): Fl. Cor(nelio) Rufino 7 ex [co]hort $[e][p] r($ imae $) \mathrm{Ha}[$ m(iorum) miliariae in Syria, genito in Asia Trallis, defuncto Aug. Tr. [ann.] LV C Ll.] Afrania Valentina coniugi karissimo viva fecit. I offer the following version, which is closer to Brouwer's text: Fl. Gordio Rufino 7 coh $\mid$ ortis [ $p$ ]r(imae) Hamae(orum)] milliariae in Syria, genitus in Asia Trallis, defunctus Aug. Tr. [ann.] LV Cla(udia) Afrania Valentina coniugi karissimo viva fecit. J.E.H. Spaul, Cohors ${ }^{2}$. The Evidence for and a Short History of the Auxiliary Infantry Units of the Imperial Roman Army. British Archaeological Reports International series 841 Oxford 2000), 504, dismisses it as "a stone probably fourth century referring to a cohors Rhama whose one-time commander died in Germany." It must be noted that Rufinus was described as a centurion not as the commander of this cohort. Spaul does not list the coh. I (H)amiorum c.R. from AE 1956, 124 under the Hamii, but at 495 lists under 'cohortes incredibiles' Rhama milliaria. 
alae, he was granted the quartae militiae honor (em) before actually gaining the command of a milliary ala. ${ }^{72}$ Whether or not Maximianus did command the Carvoran cohort, it was back there under Statius Priscus' successor as governor of Britain, Calpurnius Agricola. ${ }^{73}$

If Maximianus brought a cohort, whether of the Thracians or of the Hamii, to Cappadocia and the Pontic shore, that would have involved him taking it across the North Sea, up the Rhine, across to the Danube, and down the river into the Black Sea. The experience would have stood him in good stead a few years later, when he had a special command, as praepositus vexillationum, 'put in charge of detachments', ad deducend (a) per Danuvium quae in annonam Panno(niae) utriusq(ue) exercituum denavigarent, "to conduct along the Danube (goods) that were to move downstream to supply the armies of both Pannonias."74

A further officer who might have been taken by Priscus from Britain to the east is recorded by a statue-base from Aesernia:

$\mathrm{P}$ (ublio) Septimio P(ublii) f(ilio) Tro(mentina) Paterculo praef(ecto) coh(ortis) I Pannoni[or(um)] in Brittania, praef(ecto) coh(ortis) [II] Hispanor(um) in Cappadoc(ia), flamini divi Traiani, patrono municipi, IIIIvir(o) i(ure) d(icundo), IIIIvir(o) quinq(uennali), q(uaestori) II, $\mathrm{d}($ ecurionum $) \mathrm{d}($ ecreto $)$.

(In honour of) Publius Septimius, son of Publius, (in the) Tromentina (voting-district), Paterculus, prefect of the First Cohort of Pannonians in Brittania, prefect of the Second Cohort of Hispani in Cappadocia, flamen of the Deified Traianus, patron of the municipium, quattuorvir iure

72 It is less of a difficulty that the British cohort is not recorded with the title $c . R$. attributed to the cohort commanded by Maximianus.

73 Under this governor, in office $c .162$ to 165 , their commander dedicated two altars at Carvoran: RIB 1792: Deae Suriae, sub Calpurnio Ag[r]ico[la] leg(ato) Au[g(usti)] pr(o) pr(aetore), Licinius [C]lem[ens, praef(ectus) co]h(ortis) I Ha[miorum]; and 1809, [... sub Calpurni]o Agricola, co(n)s(ulari), Licinius Cl[e]mens $p[$ raef(ectus). For Calpurnius Agricola's dates, A.R. Birley 2005, op. cit. (n. 15), 155-7. On the coh. I Hamiorum in Britain, see now A.R. Birley, 'The cohors I Hamiorum in Britain', Acta Classica 55 (2012) 1-16 (there not making this conjecture about Maximianus).

74 The interpretation put forward here differs in several respects from that of G. Alföldy, 'P: Helvius Pertinax und M. Valerius Maximianus', Situla 14/15 (1974), 199-215, repr. in idem, Römische Heeresgeschichte (Amsterdam 1987), 326-42, with Nachträge, 342-8. 
dicundo, quattuorvir quinquennalis, quaestor twice, (set up) by decree of the decurions. ${ }^{75}$

Eric Birley noted that " $[\mathrm{t}]$ he dating is evidently Hadrianic or later; but the fact of his move from Britain to Cappadocia, for his second posting in the militia prima, suggests to me the possibility that he was moved to the East by M. Statius Priscus, to take part in the Parthian war."76 Now that the origo of Statius Priscus has been shown to be at Luceria, and that of his close family at Teanum Sidicinum, it makes good sense if it was he who offered a further appointment as prefect of a cohort to a man from Aesernia.

One may also note the career of C. (Gaius) Julius C.(Gai) f(ilius) Ani(ensis) Seneca Licinianus, which has been assigned to the period " $c a$. $100-150$ ", so is perhaps a little too early; but the dating was based solely on lettering style. ${ }^{77}$ His move from being tribune of VIVictrix in Britain to tribune of XVApollinaris in Cappadocia could be explained by his commander-in-chief having been Statius Priscus. ${ }^{78}$

There are two more equestrian officers whose appointments in Cappadocia may have been owed to Statius Priscus, both of them men whom he may have met a few years before when serving as legate of Dacia superior. First, there is C.(Gaius) Porcius C.(Gai) fil(ius) Quir(ina) Saturninus Junior, who served in two tribunates, the first in Dacia, the second in Cappadocia. ${ }^{79}$ Then there is an ignotus, whose inscription registers that he held two posts in Cappadocia, as praef(ectus) coh(ortis)III Cyrenaicae and trib(unus) leg(ionis)XII Fulm(inatae). He was a leading citizen of Sarmizegetusa, the great colonia founded by Trajan. ${ }^{80}$

\section{$4 \quad$ Conclusion}

Roman commanders have often been labelled 'amateurs', but that probably did not matter. They could rely on their junior officers, equestrians and centurions. But whereas in the Republic, especially in the age of Cicero and Caesar,

$75 \quad$ CIL 9. $2649=$ ILS 2732.

76 E. Birley, 1988, op. cit. (n. 70), 152, cited by Devijver, $P M E$ 5, Supp. 2, on S 36 . Spaul 20oo, op. cit. (n. 70), 334 dates the first post "c.a. 100"; Jarrett 1994, op. cit. (n. 37), 65: "later than 117 ”; neither cite E. Birley 1988, op. cit. (n. 70).

77 CIL 2. 6150, Barcino; G. Alföldy, Flamines provinciae Hispaniae citerioris (Madrid 1973), 75.

78 PME I 121.

$79 C I L$ 8. 1175, cf. p. 1386, Thuburbo Minus: trib. leg. XIII Gem. trib.leg. XII Fulm. See PME P 97.

8o $A E$ 1971, 267, Alba Iulia. See PME Inc. 40. 
we are well informed about how Roman commanders chose their staff, this kind of information is not available in the imperial period. Governors of provinces with large armies had ample opportunity for patronage. Tribuni laticlavii were often enough sons or sons-in-law of the governors, who clearly appointed them. ${ }^{81}$ The governor also seems to have had a free hand in appointing equestrian officers and centurions. In AD 122, the earliest year for which the evidence for the garrison of Britain is almost or less complete, there were three (if not still four) legions in the province, each with one senatorial and five equestrian tribunes and 60 centurions, and a little over 50 auxiliary regiments commanded by equestrian officers. ${ }^{82}$ All these posts could in practice be filled by the governor, even if formal imperial approval was required. But the evidence suggests that governors normally could not nominate legionary legates. Dio singles out for comment as an anomaly that Corbulo was "so trusted [sc. by Nero] not to rebel that he even took his son-in-law to command a legion, even though he had not served as praetor." Otherwise than in the Julio-Claudian period, service as praetor had long before Dio's time become a normal qualification to command a legion. But Dio seems to have misunderstood the situation in any case: Corbulo's son-in-law, Annius Vinicianus, had clearly been commissioned as a military tribune and was, as Tacitus stated, only acting commander, pro legato, of the legion VMacedonica. ${ }^{83}$ In his Ectaxis, of course, Arrian referred to several of his subordinates, but one can only guess whether he had appointed them himself and if so why. At any rate, the legate of the legion XV Apollinaris, M. Vettius Valens, ${ }^{84}$ had doubtless been assigned to that post by the emperor.

81 Literary evidence is given in A.R. Birley 1981, op. cit. (n. 15), 9 n. 22; epigraphic cases are listed ibid. 11. More names could be added, e.g. C. Cilnius Ferox under C. Cilnius Proculus, $A E$ 1946, 1, CIL 16. 46; M. Messius Rusticianus, tribune of XV Apollinaris and III Gallica, under his father-in-law. Cf. also the possible case of Tacitus, who might have served under his father-in-law Agricola, as conjectured by A.R. Birley, 'The life and death of Cornelius Tacitus', Historia 49 (2000), 230-247, at 237-238.

82 The diploma issued in July 122, CIL 16. 69, registers 13 alae and 37 cohorts in the army of Britain. On governors appointing equestrian officers see A.R. Birley, 'The commissioning of equestrian officers', in J.J. Wilkes, ed., Documenting the Roman Army (London 2003), $1-18$.

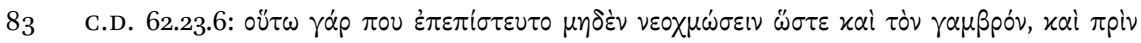

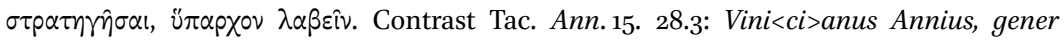
Corbulonis, nondum senatoria aetate et pro legato quintae legioni impositus. Cf. PIR ${ }^{2} \mathrm{~A} 700$.

84 Arr. Ectaxis 5 and 24. Valens' career is known from CIL 11. 383, Ariminum. He had previously been iuridicus of Britain in the 120 or 130 - quite likely under Sextus Julius Severus - at a time when the governor was preoccupied with the military problems of 
It mostly has to remain a matter of speculation or informed conjecture as to what prompted army commanders in this period to choose their subordinates. The present paper has been an attempt to supply background information focusing on two episodes in a period for which the literary sources are poor but the epigraphic sources are copious. But it must be registered that the wars which took place under Marcus Aurelius and Lucius Verus, as well as the plague brought from the east by the returning legions after the end of Parthian War, and the resultant heavy losses among the elite, led to a change in the promotion patterns. This was to be revealed most strikingly by the careers of the future emperor Pertinax and of Marcus Valerius Maximianus, whose later career, not discussed above, was to be so remarkable. ${ }^{85}$ Thereafter the frequent executions of senators under Commodus and the civil wars of 193-197 led to further changes. But that is another story.

Vindolanda, 2015

that province; and he was patron of Britain: cf. A.R. Birley 2005, op. cit. (n. 15) 272-3 and $P I R^{2} \mathrm{~V} 494$.

85 On these two see Devijver, $P M E$ H 9 with his Supp. 1 and 2; $C P$, no. 181 bis; $P I R^{2}$ V 125; Alföldy 1987 , op. cit. (n. 74). 


\title{
Die Mobilität Römischer Soldaten in Friedenszeiten
}

\author{
Peter Herz
}

$1 \quad$ Einleitung

Warum bewegten sich römische Soldaten während der Kaiserzeit überhaupt von dem Standort fort, an dem sie offiziell stationiert waren? Sicherlich war der häufigste Grund ein kriegerischer Einsatz. Diesen bereits oft traktierten Bereich der soldatischen Mobilität möchte ich mit voller Absicht nicht ansprechen, sondern die militärische Mobilität in Friedenszeiten betrachten. Mit anderen Worten, ich möchte in erster Linie die administrative Routine studieren, da sie uns einen wesentlich besseren Einblick in das Alltagsleben des römischen Militärs und seine Verwaltungsroutine gewährt.

Eine wichtige Bemerkung vorab. Man sollte die römische Armee nicht nur unter dem Aspekt ihrer militärischen Einsatzfähigkeit sehen, sondern auch als eine Anzahl von Menschen, die dem Kaiser unbegrenzt zur Verfügung standen. Denn die römische Armee (Heer und Marine) repräsentierte nicht nur den bewaffneten Arm der römischen Macht, sondern war auch die größte organisierte Gruppe an einsatzfähigen Menschen, deren Arbeitspotential vom Kaiser überall und nach seinem Belieben eingesetzt werden konnte. Dies erscheint etwas weniger überraschend, wenn man sich vor Augen führt, daß es ja auch für senatores und equites Romani keine grundsätzliche Trennung zwischen einer militärischen und einer zivilen Verwendung gab.

Die deutliche Differenzierung zwischen Militär und Zivildienst, die wir unter den Tetrarchen nachweisen können, setzt erst ab der Mitte des dritten Jahrhunderts ein und ist der eigentlichen Kaiserzeit eher fremd. Dabei sollte man auf jeden Fall berücksichtigen, daß die Römer Pragmatiker waren und daher jeweils auf die personellen Ressourcen zurückgriffen, die sie gerade zur Hand hatten.

Wie fließend die Grenzen zwischen dem militärischen und dem eigentlich zivilen bzw. hoheitlichen Aufgabenbereich sein konnte, zeigt ein Zeugnis aus dem Archiv der Babatha. Dabei fungiert ein praefectus equitum (wohl der 
Kommandeur einer ala des Provinzheeres) als Vertreter des römischen Staates, vor dem der Eid auf die Richtigkeit der census-Deklaration abgelegt wurde. ${ }^{1}$

Ich beabsichtige in meinem Beitrag eine kurze Übersicht zu den vielfältigen Möglichkeiten zu geben, wie römische Soldaten und Offiziere im Dienste des Kaisers auch in Friedenszeiten kreuz und quer durch das Imperium Romanum verschoben werden konnten, um so etwas die Vielfältigkeit der römischen Administration zu illustrieren. ${ }^{2}$

Am Ende soll eine Art von 'working model' stehen, das nach Belieben ergänzt oder verändert werden kann. Vor dem Hintergrund eines solchen Modells sollte es dann auch möglich sein, die Anstrengungen besser zu beurteilen, die die Mobilisierung und Verlegung großer Truppenverbände in Kriegszeiten notwendig machten. ${ }^{3}$

Eine Feststellung darf aber schon zu Beginn gemacht werden. Es dürfte kaum möglich sein, ein Modell zu entwerfen, das ohne Unterschied für alle Provinzen gültig ist. Dazu sind die strukturellen Voraussetzungen und auch die Aufgabenstellung in den einzelnen Provinzen zu unterschiedlich gewesen.

\section{Mobilität innerhalb der Heimatprovinz}

Unter dem Begriff 'Heimatprovinz' ist die Provinz zu verstehen, in der sich der feste Standort der militärischen Einheit befindet, der der Soldat offiziell zugeteilt wurde und wo sein Name in der Stammrolle (matricula) der Einheit verzeichnet ist.

Dabei haben wir zunächst die Außenstellen des Stammlagers zu berücksichtigen, zu denen die Soldaten ausrückten. In diese Kategorie gehören kleinere, vom Hauptlager administrativ abhängige Lager oder Einrichtungen wie Depots und Ziegeleien. Einige Einheiten wie die cohors IIII Vindelicorum scheinen auf

1 B. Isaac, 'Tax collection in Roman Arabia. New evidence from the Babatha archive,' Mediterranean Historical Review 9 (1994), 256-266 = The Near East under Roman rule. Selected Papers (Leiden, New York, Köln 1998), 322-333.

2 Wichtig: P. Faure, 'Combattre ou ne pas combattre: métier légionnaire et mobilité militaire dans la première moitié du III e siècle apr. J.-C.', in C. Wolff, Hg., Le métier de soldat dans le monde romaine. Actes du cinquième congrès de Lyon organisé les 23-25 septembre 2010 par l'universitéJean Moulin Lyon 3 (Lyon 2012), 369-416.

3 Wie weitgespannt Mobilität in der Antike war, beweisen die Beiträge in E. Olshausen und V. Sauer, Hg., Mobilität in den Kulturen der antiken Mittelmeerwelt. Stuttgarter Kolloquium zur Historischen Geographie des Altertums 11, 2011. Geographica Historica 31 (Stuttgart 2014). 


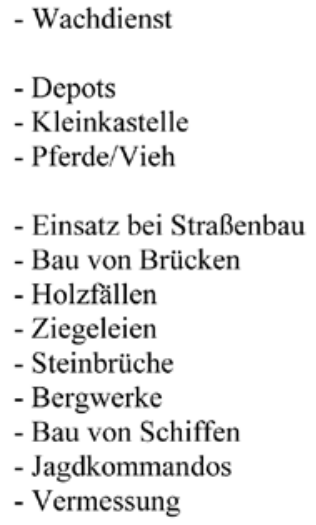

Officium des Statthalters

Schreibstube

- beneficiarii

- eq. /ped. singulares

- Stratores

- Officia von procuratores in der Provinz

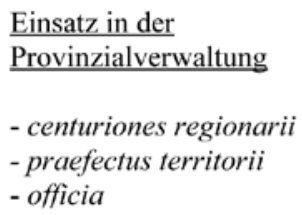

SCHEMA 5.1 Mobilität innerhalb der Heimatprovinz.

den Betrieb von Ziegeleien spezialisiert gewesen zu sein, da sich ihr Name auf vielen Ziegeln nachweisen läßt, die überall in der provincia Germania superior gefunden wurden. ${ }^{4}$ Während diese Einheit wohl in Heddernheim ihr Stammlager hatte, scheinen Baueinheiten überall in der Provinz Ziegeleien betrieben zu haben, die dann in den benachbarten Kastellen verwendet wurden.

Danach kommen Sonderaufträge. In diese Gruppe von Aufträgen gehören die Beschaffung von Holz, Holzkohle und Kalk, die Arbeit in Steinbrüchen und der anschließende Transport der Steine zum Bauplatz sowie der Einsatz beim Bau von Straßen und Brücken. ${ }^{5}$ Kleinere Gruppen von Soldaten dürften auch

4 Vgl. die knappen Angaben bei J. Spaul, Cohors². The Evidence for and a Short History of the Auxiliary Infantry Units of the Imperial Roman Army (Oxford 2000), $290 \mathrm{f}$.

5 Vgl. die Beiträge von Ch. Schmidt Heidenreich, 'Les soldats bâtisseurs dans les camps sous le Haut-Empire', und G. Wesch-Klein, 'Lapidarii des exercitus Romanus', in C. Wolff, Hg., Le métier de soldat dans le monde romaine. Actes du cinquième congrès de Lyon organisé les 23-25 septembre 2010 par l'Université Jean Moulin Lyon 3 (Lyon 2012), 327-344 bzw. 345-365. Am besten sind wir für die großen Steinbrüche in Ägypten informiert, vgl. neben der älteren 
bei der Vermessung eingesetzt gewesen sein. ${ }^{6}$ Eher dem zivilen Sektor zugeordnet sind Hilfsdienste bei der Durchführung des census und der Eintreibung von Sachabgaben der Bevölkerung innerhalb der Provinz.

Als Sondergruppe verstehe ich den Einsatz bei militärischen Jagdkommandos, um etwa wilde Tiere für die venationes zu fangen. Solche Kommandos sind für die Bärenjagd in Germanien, sowie für die Jagd auf Büffel bzw. Wisente auf dem Balkan gesichert. ${ }^{7}$ Damit haben wir wohl nur die Spitze des Eisbergs vor uns, denn der Bedarf an solchen Tieren dürfte enorm gewesen sein. So sind vergleichbare Einsätze etwa bei der Jagd auf Löwen, möglicherweise sogar auf Elephanten in Nordafrika durchaus denkbar.

Eine weitere Gruppe von Aufgaben bedeutete die langfristige oder sogar permanente Abkommandierung zu officia innerhalb der Provinz. Diese Soldaten verblieben zwar noch offiziell auf der Stammrolle ihrer Einheit, waren aber nicht mehr für den Routinedienst oder militärische Kommandos greifbar.

Unabhängig von der Größe einer Provinz oder der Größe des jeweiligen Provinzheeres bestand im Stab eines Statthalters ein ständiger Bedarf vor allem an schreibkundigen Soldaten für das officium. Hinzu kommen die beneficiarii, die equites und pedites singulares und auch die stratores. ${ }^{8}$ Bei den stratores

Arbeit von M.J. Klein, Untersuchungen zu den kaiserlichen Steinbrüchen am Mons Porphyrites und Mons Claudianus in der östlichen Wüste Ägyptens (Bonn 1988); auch D. Peacock und V. Maxfield, Hg., The Roman Imperial Quarries. Survey and Excavation at Mons Porphyrites, 1994-1998. Vol.II. The Excavations (London 2007).

6 Vgl. den Briefwechsel zwischen Plinius und Trajan (Plin. Ep. 10.17 b. und 18) wegen der Delegierung eines Vermessungsspezialisten für Prusa. Der klassische Fall ist der Bau der Wasserleitung von Saldae ( $C I L$ 8. $2728=I L S$ 5795). In der Regel konzentriert man sich auf die Arbeit des veteranus Varius Clemens, übersieht aber, daß beim Bau auch milites classiarii eingesetzt wurden. D. Kienast, Untersuchungen zu den Kriegsflotten der römischen Kaiserzeit (Bonn 1966), 99 Anm. 65 vermutet abkommandierte Soldaten des in Caesarea stationierten Geschwaders.

7 Im Jahre 147 organisierte ein tribunus der cohors I Cilicum zusammen mit vexillationes der legio I Italica, der legio XI Claudia sowie der classis Moesiaca eine große Jagd auf Bären und Wisente (ursis et visontibus prospere captis). Vgl. dazu V. Velkov, G. Alexandrov, 'Venatio Caesariana. Eine neue Inschrift aus Montana (Moesia inferior)', Chiron 18 (1988), 271-277. J. Kolendo, "Des boeufs sauvages" - Les bisons d'Europe dans les balkans depuis l'invasion de Xerxés jusqu'aux invasions slaves', in S. Rucinski, C. Balbuza und Ch. Królczyk, Hg., Studia Lesco Mrozewicz ab amicis et discipulis dedicata (Poznan 2011), 173-180. Für die Involvierung von Soldaten in den Bereich der venationes vgl. auch CIL 6. $130=I L S 2091$ mit Soldaten der cohortes praetoriae, die als venatores immunes und custos vivarii fungieren.

8 Literatur zu diesen Gruppen: J. Ott, Die Benefiziarier. Untersuchungen zu ihrer Stellung innerhalb der Rangordnung des römischen Heeres und zu ihrer Funktion (Stuttgart 1995); J. NelisClément, Militaires et administration au service de l'Empire (1er s. av. J.C.-VI s. ap. J.C.) (Les 
scheint sich ein System abzuzeichnen, bei denen die centuriones stratorum mit Absicht aus legiones genommen wurden, die nicht in der Provinz stationiert waren, wo sie Dienst taten. ${ }^{9}$

Analog dazu bestand auch ein permanenter Bedarf an Soldaten für die officia der unterschiedlichen procuratores. Im Falle der Provinz Germania superior bedeutete dies z.B. die Abkommandierungen zum procurator duarum Germaniarum et Belgicae, daneben sind auch noch Abkommandierungen zum Stab der procuratores der res privata und des patrimonium für diese drei Provinzen zu berücksichtigen. ${ }^{10}$

Vom obergermanischen Limes ist der Einsatz von centuriones der Legionen in kleineren Lagern bekannt, die dort das Kommando hatten, obwohl sie immer noch in der Stammrolle ihrer Einheit geführt wurden. Dazu ein kleines Beispiel:11

Fortunae Conservatrici C(aius) Iul(ius) Maianus (centurio) leg(ionis) VIII Aug(ustae) v(otum) s(olvit) l(ibens) m(erito)

Der bewahrenden Fortuna. Gaius Iulius Maianus, Hauptmann der legio VIII Augusta, hat sein Gelübde gern und wie es sich gebührt eingelöst.

Aus derselben Kategorie wäre auch die Abkommandierung als centurio regionarius bzw. praefectus gentis zu berücksichtigen, wobei dem centurio auch noch einige Soldaten für sein officium zugeordnet waren. ${ }^{12}$

Beneficiarii) (Bordeaux 200o); M.P. Speidel, Guards of the Roman Armies. An Essay of the Singulares of the Provinces (Bonn 1978).

9 Vgl. $A E$ 1985, 829 für L. Valerius Valerianus, dessen centurio strator von der legio VI Ferrata kam. Vgl. M.P. Speidel, 'Valerius Valerianus in charge of Septimius Severus' Mesopotamian campaign', Classical Philology 8o (1985), 321-326 = Roman Army Studies II (Stuttgart 1992), 218-223. Ähnliches scheint sich auch bei Claudius Candidus und Fabius Cilo anzudeuten, deren centuriones stratores von der legio X Gemina (RIT $130=C I L 2^{2} / 14 \mathrm{Nr}$. 975) bzw. von der legio VMacedonica (CIL 6.1408 = ILS 1141) kamen.

10 Vgl. H. Bernhard, 'Die römische Geschichte in Rheinland-Pfalz', in H. Cüppers, Hg., Die Römer in Rheinland-Pfalz (Stuttgart 1990. Nachdruck Hamburg 2002), 39-168, bes. 103 für die unterschiedlichen militärischen Gruppen, die in der Administration einer provincia eingesetzt wurden.

11 CIL 13. 7733 (Bad Ems).

12 Vgl. z.B.AE 1990, 858 mit mil(es) leg(ionis) VII Cl(audiae) librarius offici(i) prae(fecti) ter(r)it(orii). Vgl. R. Alston, Soldier and Society in Roman Egypt (London und New York 1995), 86-96 mit Anm.; 113-129 mit Belegen für abkommandierte centuriones bzw. beneficiarii in den Nomen. Ebenso A.Z. Bryen, Violence in Roman Egypt. A Study in Legal Interpretation 
Eine gewisse Vorstellung, zu welchen Kommandos Soldaten innerhalb einer provincia abkommandiert werden konnten, liefern die Papyri. Dabei ist die Gruppe von Quittungen besonders wichtig, die Soldaten bei dem summus curator ihrer Einheit abgeben mußten, wenn man ihnen wegen eines Einsatzes das Heugeld oder das Verpflegungsgeld (epulum) auszahlte, das üblicherweise von ihrer Einheit verwaltet wurde. ${ }^{13}$ Welche konkreten Aufgaben diese Soldaten an ihren Zielorten zu erledigen hatten, wird leider in der Regel nicht angegeben. Es dürften aber vermutlich Aufgaben als Wachsoldaten oder Begleiter von Transporten im staatlichen Auftrag gewesen sein. ${ }^{14}$

Ebenso unklar ist auch die Beteiligung von Soldaten bei wirtschaftlichen Unternehmungen, die im öffentlichen Auftrag innerhalb der Provinz stattfanden. ${ }^{15}$ Hier ist noch ein bedeutender Klärungsbedarf.

\section{Mobilität außerhalb der Heimatprovinz}

Die erste Kategorie enthalt permanente oder längerfristige Abkommandierungen. Hier sind all die Soldaten und Offiziere zu berücksichtigen, die aus einer Militärprovinz in die officia der benachbarten provinciae inermes abkommandiert wurden. Dabei sind sowohl die officia der jeweiligen

(Philadelphia 2013), 19 mit weiterer Literatur in Anm. 15; vgl. dort auch die Texte der Petitionen 214 ff., demnach nahmen regelmäßig centuriones, beneficiarii und stationarii Petitionen aus der Zivilbevölkerung in Empfang. Unklar ist die genaue Funktion des aus C.D. 72.12.4 bekannte centurio. War er ein centurio (regionarius) oder war er lediglich mit der Steuererhebung beschäftigt? Vgl. K. Blouin, Triangular Landscapes. Environment, Society, and the State in the Nile Delta under Roman Rule (Oxford 2014), 267-297 zum Aufstand der boukoloi und der Involvierung der Militärs bei der lokalen Steuereintreibung.

13 R.O. Fink, Roman Military Records on Papyrus (Ann Arbor 1971), Nr. 76 mit einer großen Zahl an Einzelquittungen.

14 Die Bewachung der wichtigen Straßenverbindungen zu den Häfen des Roten Meeres dürfte sehr personalintensiv gewesen sein. Zum Stand der Forschung vgl. H. Cuvigny, Hg., La route de Myos Hormos. L'armée romaine dans le désert oriental d'Égypte. Praesidia du désert de Bérénice I.II (Patis 2003) und dies., Hg., Didymoi. Une garnison romaine dans le désert oriental d'Égypte I. Les fouilles et le materiel (Caire 2012).

15 O. Stoll, 'Armee und Agrarwirtschaft: die "Stationen" vor dem norisch-pannonischen Limes und die Landwirtschaft im "Freien Germanien"', in ders., Römisches Heer und Gesellschaft. Gesammelte Beiträge 1991-1999 (Stuttgart 2001), 452-511 zur möglichen Involvierung der Armee in die Landwirtschaft ihres Stationierungsgebietes. Vgl. auch A. Mócsy, 'Das Problem der militärischen Territorien im Donauraum', Acta Antiqua Academiae Scientiarum Hungaricae 20 (1972), 133-168 = Pannonien und das römische Heer. Ausgewählte Aufsätze (Stuttgart 1992), 125-160. 


\section{Fallweise Kommandos}

Beschaffung von Lebensmitteln,

Kleidung,

Waffen,

Ausrüstung
Officia von Statthaltern

Officia von procuratores

\section{Permanente Kommandos}

Vexillatio von Lyon;

Cohors von Carthago

Einheiten Schwarzmeer;

portus expeditionales; Aufmarschdepots
Offiziere; Mannschaften

- Begleitung von tirones

- Versetzung in andere Provinzheere (Offiziere/Mannschaften)

- Begleitung von Häftlingen zum Gerichtsort bzw. ins Exil oder Haftort

- Versetzung zu cohortes praetoriae, equites singulares, castra peregrina

- Von den castra peregrina

- Außenkommandos

- Sonderaufträge

- Vexillatio der Misenenses/Ravennates

SCHEMA 5.2 Mobilität außerhalb der Provinz.

Provinzstatthalter als auch die officia von diversen procuratores zu berücksichtigen (s.o.).

Die innergallischen Provinzen (Belgica, Lugdunensis, Aquitania) erhielten ihr Personal in erster Linie aus dem Personalbestand der Rheinlegionen. Diese mußten daher neben den officia ihrer jeweiligen Heimatprovinz auch noch die officia von drei Provinzstatthaltern sowie die diverser procuratores bedienen.

Die Zivilprovinzen Dalmatia, Epirus, und Macedonia erhielten ihre Soldaten wahrscheinlich aus dem Mannschaftsbestand der Donauprovinzen. ${ }^{16}$

16 Vgl. R. Haensch, 'Altäre von Armeeangehörigen aus Kleinasien', in A.W. Busch und A. Schäfer, Hg., Römische Weihealtäre im Kontext. Internationale Tagung in Köln vom 3 . Bis zum 5. Dezember 2009. "Weihealtäre in Tempeln und Heiligtümern" (Friedberg 2014), 369-379, bes. $370 \mathrm{ff}$. zu einer offensichtlich permanent stationierten vexillatio nach M.A. Speidel, 'Les longues marches des armées romaines. Réflets épigraphiques de la circulation des militaires dans la province d'Asie au III ${ }^{\mathrm{e}} \mathrm{s}$. ap. J.-C.,', Cahiers du Centre Gustave Glotz 20 (2009), 188-210, bes. 206 Anm. 29. Vgl. auch R. Haensch, 'Kolletiones et canalicularii', in C. Wolff, Hg., Le métier de soldat dans le monde romaine. Actes du cinquième congrès de Lyon organisé les 23-25 septembre 2010 par l'UniversitéJean Moulin Lyon 3 (Lyon 2012), 503-511. 
Die kleinasiatischen Provinzen dürften teils von Einheiten an der unteren Donau (westlicher Teil), teils von den Truppen in Kappadokien (östlicher Teil) versorgt worden sein. Bei den kleinasiatischen Binnenprovinzen bezweifle ich, daß die Personalstärke einer dort stationierten cohors quingenaria ausreichend war, um alle dort anfallenden Aufgaben aus dem vorhandenen Personalbestand zu bewältigen.

Eingut bekannter Sonderfall ist dievexillatio dervier germanischen Legionen in Lugdunum, die dort seit Septimius Severus die frühere cohors urbana abgelöst hatte. ${ }^{17}$ Trotzdem ergeben sich hier einige Probleme. Zunächst ist m.E. noch nicht abschließend geklärt worden, wie stark diese vexillatio eigentlich war. War es eine quingenaria oder eine milliaria? Ich würde zu einer vexillatio milliaria tendieren, die verwaltungsmäßig dann auch die Mannschaften in sich vereinigte, die die officia der unterschiedlichen Funktionäre mit Soldaten und Offizieren versorgen mußten, deren Dienstsitz in Lyon war. Da die so entstandenen Mannschaftslücken bei den rheinischen Legionen wahrscheinlich nicht ersetzt wurden, bedeutet dies, daß jede der vier hochkaiserzeitlichen Legionen den Mannschaftsbestand von rund 3 centuriae $=$ ca. 240 Mann oder rund 5 Prozent ihrer Stärke permanent abgeben mußte. ${ }^{18}$

Ebenfalls zur Gruppe der permanenten Abkommandierungen gehört die regelmäßig zum proconsul Africae in Carthago abkommandierte cohors der legio III Augusta. ${ }^{19}$ Hier können wir davon ausgehen, daß diese cohors in einem Rotationsverfahren zwischen Carthago und dem Stammlager ausgetauscht wurde, damit jede cohors (wahrscheinlich abgesehen von der cohors prima) die Chance hatte, dieses begehrte Kommando zu übernehmen. Einen ähnlich permanenten Charakter dürften die vexillationes der niedermösischen Armee auf der Krim und in den verbündeten Städten im Pontus-Gebiet gehabt haben. ${ }^{20}$ Die Stabssoldaten (10 beneficiarii, 2 equites und 1 centurio) des Gavius Secundus, des praefectus orae Ponticae, wurden laut Plinius aus den cohortes

17 The Encyclopedia of the Roman Army (Oxford 2015), 1055 zum Schicksal der cohors XIII urbana von Lugdunum.

18 Ich vermute, daß diese vexillatio von einem equestren tribunus militum kommandiert wurde, der wahrscheinlich alternierend von ein den vier legiones abkommandiert wurde.

19 Y. Le Bohec, La troisième legion Auguste (Paris 1989). Vgl. auch N. Duval, S. Lancel und Y. Le Bohec, 'Études sur la garnison de Carthage. Deux documents nouveaux - Les troupes de Proconsulaire - Le camp de la cohorte urbaine', Bulletin du Comité des Travaux historique (1984), 47-79 = Y. Le Bohec, L'armée romaine en Afrique et en Gaule (Stuttgart 2007), $333-389$.

20 Zum Einstieg: T. Bekker-Nielsen, Hg., Rome and the Black Sea Region. Domination, Romanisation, Resistance. Black Sea Studies 5 (Århus 2006). 
genommen, die in der provincia stationiert waren (ex cohortibus, quibus me praeesse voluisti). ${ }^{21}$

Der ständige Kampf der Amtsträger in den Provinzen um mehr Soldaten für ihre jeweiligen officia wird im Briefwechsel des Plinius besonders deutlich, dürfte aber im Prinzip für alle Provinzen gegolten haben. ${ }^{22}$ In der von Plinius verwalteten Binnenprovinz dürften sich diese Wünsche noch in Grenzen gehalten haben. Wenn man aber die Anzahl der wichtigen Dienststellen etwa in der provincia Aegyptus betrachtet oder in den großen Provinzen wie Britannien, Syrien oder den beiden Germanien, dann dürften die Forderungen dort entsprechend gestiegen sein. ${ }^{23}$

Daneben ist mit längerfristigen Abkommandierungen in wichtige Häfen zu rechnen, um den Nachschub für die Stammeinheit oder das gesamte Provinzheer zu organisieren. Hier wäre zunächst an Aquileia zu denken, wo Untergebene von primi pili der Donaulegionen nachgewiesen sind. ${ }^{24}$ Analog darf man die Existenz von weiteren Häfen mit dieser Aufgabenstellung (portus expeditionales) postulieren. Dazu gehörten wahrscheinlich die Hafenstädte Salona, Thessalonike, Perinthos, Seleucia in Pierien, Laodiceia und Caesarea Maritima.

$\mathrm{Zu}$ den permanenten Kommandos kann man auch den Einsatz als Begleitpersonal zählen, um Rekruten und Nachschub in die Einsatzprovinz zu eskortieren. Bei dem Transfer von Rekruten sind drei unterschiedliche Aufgabentypen zu berücksichtigen.

Erstens, Rekrutierung in den unmittelbaren Nachbarprovinzen. Dies wären die innergallischen Provinzen für den Mannschaftsersatz der Rheinlegionen, möglicherweise auch für den rätischen exercitus. Daneben sind regelmäßige Rekrutierungen in Germania inferior und der Belgica für die britannischen Einheiten anzunehmen.

21 Plin. Ep. 10.21. Die speziellen Beziehungen der provincia Bithynia et Pontus zum exercitus von Moesia inferior scheint sich auch in der alljährlichen Grußgesandtschaft anzudeuten, die die Stadt Byzantion an den dortigen Statthalter schickte (Plin. Ep. 10.43 f.). In Plin. Ep. 10.27 f. wird berichtet, daß der kaiserliche libertus Maximus, der als adiutor des ritterlichen procurator amtierte, mit der Zahl der 10 beneficiarii, die ihm zugeteilt worden waren, nicht zufrieden war und daher zusätzliche Soldaten wünschte.

23 Es wäre wünschenswert, wenn auf der Basis von A. Jördens, Statthalterliche Verwaltung in der römischen Kaiserzeit. Studien zum praefectus Aegypti (Stuttgart 2009) berechnet würde, wieviele Soldaten dort in der Verwaltung eingesetzt waren.

24 L. Mócsy, 'Das Lustrum Primipili und die Annona Militaris', Germania 44 (1966), 312-326, = in ders., Pannonien und das römische Heer. Ausgewählte Aufsätze (Stuttgart 1992), 106120 (mit Nachträgen). Vgl. auch P. Herz, 'Der centurio supernumerarius und die annona militaris', Laverna 10 (1999 [200o]), 165-184. 
Zweitens, Rekrutierungin Provinzen, dievom künftigen Stationierungsgebiet weiter entfernt sind. Ich habe dazu fünf ausgewählte Fälle herangezogen, die sicherlich nur einen Bruchteil der wirklich durchgeführten Rekrutierungsaktionen dieser Art repräsentieren dürften: Rekrutierung in Asia für das Heer in Aegyptus; ${ }^{25}$ Bessi für Mauretania Tingitana; ${ }^{26}$ Thrakische und pannonische Soldaten usw. für die Heere in den beiden germanischen Provinzen; ${ }^{27}$ Cilices für die Donau-Legionen; ${ }^{28}$ Soldaten aus Lykien für das Heer in Syria. ${ }^{29}$

Je nach Größe des Kontingents dürften mehrere Offiziere und eine Anzahl von Mannschaften notwendig gewesen sein, um den Transport zu begleiten und auch die notwendigen administrativen Aufgaben zu erledigen.

Drittens, Transfer von Soldaten zu neuen Einheiten. Hier geht es nicht um die Erfassung und Eskortierung von tirones, sondern um den endgültigen Transfer von bereits ausgebildeten Soldaten. Für diese Soldaten handelt es sich im Gegensatz zu den permanenten vexillationes um eine endgültige Versetzung zu einer neuen Einheit. ${ }^{30}$ Daneben ist bekannt, daß z.B. regelmäßig

$25 \quad$ PSI 1063 (3. September 117 n.Chr.) = Fink 1971, a.a. O. (Anm.13), Nr. 74.

26 M.P. Speidel, 'A thousand Thracian recruits for Mauretania Tingitana', Antiquité Africaine 11 (1977), 167-173, = in ders., Roman Army Studies I (Amsterdam 1984), 341-347. Vgl. auch dens., 'Numerus Syrorum Malvensium. The transfer of a Dacian army unit to Mauretania and its implications', Dacia 17 (1973), 169-177 = Roman Army Papers I (Amsterdam 1984), 149-16o.

27 Hdn. 6.8.2 f. Hierbei wurde ein großes Kontingent von tirones aus dem Balkangebiet unter dem Kommando des späteren Kaisers Maximinus Thrax ausgehoben und nach Germanien verlegt, um dort die Lücken aufzufüllen, die die Einheiten während der expeditio Orientalis erlitten hatten. Vgl. L. Schumacher, Römische Kaiser in Mainz. Im Zeitalter des Principats (27 v.Chr.-284 n.Chr.) (Bochum 1982), 85-92. Auch schon im Jahre 223 ist eine Gruppe von thrakischen Soldaten in Germania inferior nachgewiesen, die offensichtlich zur Auffrischung an den Rhein verlegt worden waren (ILS 2350).

28 M.P. Speidel, 'Contirones et Geta dominus noster', Ziva Antica 39 (1989), 55-56 = AE 1990, 854 = Inscriptions de la Mésie Supérieur, Nr. 3 (Singidunum). Zuletzt D. Grbic, 'The Cilicians in Singidunum. Notes on military epigraphy and topography', Starinar 57 (2007), 221-227.

29 N.P. Milner, 'Athletics, army recruitment and heroisation: L. Sep. Fl. Flavillianus of Oinoanda', Anatolian Studies 61 (2011), 151-167; P. Herz, 'Zur Karriere des Lucius Septimius Flavianus Flavillianus aus Oinoanda', in B. Takmer et al., Hg., Vir doctus anatolicus. Studies in Memory of Sencer Sahin (Istanbul 2016), 464-470 (im Druck).

30 Vgl. den Transfer afrikanischer Soldaten nach Syrien unter Hadrian. M.P. Speidel, Emperor Hadrian's speeches to the African army - A New Text. Monographien des RömischGermanisches Zentralmuseums 65 (Mainz 2006). Für eine Verlegung von syrischen 
ausgewählte Kavalleristen aus den Provinzen zu den equites singulares Augusti abkommandiert wurden. ${ }^{31}$

In eine ähnliche Kategorie müssen wir die Abkommandierung zu den cohortes praetoriae seit Septimius Severus einordnen. Während die im Jahre 193 neu konstituierten cohortes praetoriae in ihrer ersten Welle durch Soldaten und Offiziere formiert wurden, die aus den Beständen der Donau-Legionen abkommandiert worden waren, scheint man später eher zu einer direkten Rekrutierung in ausgewählten Gebieten übergegangen zu sein. Nimmt man die späteren Militärdiplome als Indikator, so scheint sich eine deutliche Bevorzugung des südlichen Balkan anzudeuten. Der Ersatz für die Eliteeinheit der Mauri et Osrhoeni scheint immer aus den Ursprungsgebieten gekommen zu sein.

Fallweise Kommandos betreffen u.a. die Beschaffung und den Transport von Nachschub. Zunächst Kleidung. Aus Hunt's Pridianum wissen wir, daß von dieser Einheit Soldaten abkommandiert worden waren, um Kleidung aus Gallien für Truppen zu begleiten, die in der Provinz Macedonia stationiert waren. ${ }^{32}$ Daneben ist auch die Lieferung von Decken aus Ägypten zum Heer in Kappadokien gesichert. ${ }^{33}$

Hinzu kommen die Waffen. Neben dem Wachpersonal für den Transport zur Einheit ist auch die längerfristige Abkommandierung von Offizieren und Mannschaften in die eigentlichen Produktionsgebiete zu berücksichtigen. Typisch dafür ist die folgende Inschrift: ${ }^{34}$

M. Ulpio Avito (centurioni) leg(ionis) III Aug(ustae) IIII Fl(aviae) opifices loricari(i) qui in Aeduis consist(unt) et vico Briviae Sugnuntiae respondent quiq(ue) sub cura eius fuerunt, erga ibs[os] b(ene) [m]er(enti) pos(uerunt).

Für Ulpius Avitus, dem centurio der legio III Augusta (und) der legio IIII Flavia, die Hersteller von Rüstungen, die sich im Gebiet der Haeduer aufhalten und zu dem vicus Brivia Sugnuntia gehören und die unter seiner

Soldaten nach Nordafrika vgl. Y. Le Bohec, 'Les Syriens dans l'Afrique romaine', Karthago 21 (1987), 81-92 = L'armée romaine en Afrique et en Gaule (Stuttgart 2007), 453-464.

M.P. Speidel, Die Denkmäler der Kaiserreiter. Equites singulares Augusti. Beihefte der Bonner Jahrbücher 50 (Bonn 1994).

32 Fink 1971, a.a.O. (Anm. 13), Nr. 63.

$33 B G U$ 7.1564 = Sel. Pap. 2. 395. Zum System der Kleiderbeschaffung (vestis militaris) vgl. J.A. Sheridan, Columbia Papyri IX. The Vestis Militaris Codex (Atlanta 1998), 73-86.

$34 \quad$ CIL 13. $2828=$ ILS 7047 (Monceaux-le-Comte). 
Aufsicht waren. Sie haben es (für ihn), der sich um sie wohl verdient gemacht hat, errichtet.

Auch bei der Beschaffung von Pferden und Maultieren wurden Soldaten eingesetzt. Administrativ war dies die Aufgabe der centuriones stratores, die aus dem Bestand einer legio in das officium eines Statthalters abkommandiert worden waren. Über welche Distanzen die Pferde für die Einsatzprovinzen herangeschafft wurden, ist ein bisher noch kaum erforschtes Problem.

Daneben waren Soldaten auf mit der Aufsicht bei unterschiedlichen militärischen Baukommandos.befaßt. Dazu gehören die Baumaßnahmen, die nicht aus der Initiative einer Einzelprovinz begonnen wurden, sondern bei denen die entsprechenden Maßnahmen direkt von der Reichszentrale angeordnet wurden. Dazu gehört z.B. der Bau von Schiffen für die expeditio Britannica des Septimius Severus in Mainz. ${ }^{35}$
$\mathrm{I}$ (ovi) $\mathrm{O}$ (ptimo) $\mathrm{M}$ (aximo) Dolicheno pr[o] salute $\mathrm{dd}$ (ominorum) nn(ostrorum) Augg(ustorum) vexill(atio) leg(ionis) P(rimigeniae) p(iae) $\mathrm{f}$ (idelis) agent(ium) in lignar(iis) sub Clod(io) Caerellio (centurione) leg(ionis) I Part(icae) curam agent(e) Maior(io) Urbano optione [A]n[ni] o et Aemil[iano] co(n)s(ulibus).

Dem besten und größten Iuppiter von Doliche. Für das Wohlergehen unserer beiden Herren, der Augusti. Ein Detachement der legio XXII Primigenia, mit den Beinamen 'die gehorsame, die treue', der Männer, die beim Holzfällen eingesetzt sind unter dem Kommando der Clodius Caerellius, eines centurio der legio I Parthica. Aufsicht führte der Feldwebel Maiorius Urbanus. Unter den Konsuln Annius und Aemilianus.

Die übergeordnete Initiative wird durch die Anwesenheit eines centurio ( frumentarius) aus dem Bestand der legio I Parthica aus Mesopotamien gesichert.

DerEinsatz eines centurio in einem Gebiet, das so weit vom Stationierungsort seiner Stammeinheit entfernt war, läßt sich problemlos durch weitere Belege absichern. Denn wenn man die Nachrichten zu den bisher bekannten Verwendungsmöglichkeiten der centuriones sichtet, dann darf man durchaus feststellen, daß die centuriones fast eine Art von 'Allzweckwaffe' des römischen Staates waren. Centuriones stellten nicht nur das organisatorische Rückgrat der 
eigentlichen Armee, sondern sie waren auch vielseitig überall dort einsetzbar, wo es die Autorität des römischen Staates erforderlich machte. ${ }^{36}$ Man könnte sie daher durchaus als eine rangniedere Variante zu den Vertretern der senatorischen und equestren Laufbahn verstehen, die ja in der Praxis auch für alle Aufgaben eingesetzt werden konnten.

Centuriones konnten daher jederzeit alle möglichen Verwaltungsaufgaben oder polizeiliche Funktionen übernehmen. Sie konnten Steuern eintreiben oder Baumaßnahmen aller Art überwachen, wenn diese im Interesse der Zentralregierung notwendig waren. Daher konnten sie auch ohne weiteres zu Einsatzorten versetzt werden, die weit von ihren Stammeinheiten entfernt waren. ${ }^{37}$

Ob die Delegierung eines centurio immer sachlich gerechtfertigt war oder lediglich dazu diente, die Bedeutung eines höheren Funktionärs zu unterstreichen, läßt sich kaum endgültig entscheiden. ${ }^{38}$

\section{$4 \quad$ Einsatz in der innerbetrieblichen Kommunikation}

Am Ende jedes Dienst- bzw. Feldzugsjahres mußte der aktuelle Ist-Bestand einer Einheit zusammengefasst werden, um dann an den Kommandeur des Provinzheeres gemeldet zu werden. Dies dürfte in der Regel durch einen

36 Am besten sind wir zu den centuriones der beiden Heere am Rhein informiert, vgl. O. Richier, Centuriones ad Rhenum. Les centurions légionaires des armées romaines du Rhin (Paris 2004). Materialreich, aber auf die Periode der Severer beschränkt ist die Arbeit von P. Fauré, L'aigle et le cep. Les centurions légionaies dans l'Empire des Sévères (Bordeaux 2013), der 539 ff. einen gut kommentierten Katalog der bekannten centuriones bietet.

37 Vgl. etwa I. Piso und C. Cupcea, 'Ein centurio regionarius der legio X Fretensis in Dakien', Tyche 29 (2014), 115-123 mit weiterem Material. Vgl. auch B. Rankov, 'A contribution to the military and administrative history of Montana', in A.G. Poulter, Hg., Ancient Bulgaria. Papers presented to the International Symposium on the Ancient History and Archaeology of Bulgaria II (Nottingham 1983), 40-73. Ähnlich auch A.M. Hirt, Imperial Mines and Quarries in the Roman World. Organizational Aspects $27 B C-A D 235$ (Oxford und New York 2010), 170 u. 412 Nr. 618 zu einem centurio der legio XXII Primigenia, der offensichtlich in den Steinbrüchen von Karystos eingesetzt war.

38 Vgl. etwa P. Herz, Studien zur römischen Wirtschaftsgesetzgebung. Die Lebensmittelversorgung (Stuttgart 1988), 77 nach Dig. 13.7.43.1 und 119 Anm. 67 nach CIL 14. 125 = ILS 2223 mit einem centurio ann(onae) oder ann(onarius). Vgl. H. Pavis d'Escurac, La préfecture de l'annone. Service administratif imperial d'Auguste à Constantin (Rome 1976), 101 Anm. 74. Ähnlich AE 1977, 171. Man beachte auch den centurio operum in CIL 14. 125 = ILS 2223. Leider läßt sich der Quelle nicht entnehmen, aus welcher Truppe diese beiden centuriones delegiert worden waren. 


\begin{tabular}{l|l|}
\cline { 2 - 2 } $\begin{array}{l}\text { Innerhalb } \\
\text { der Provinz }\end{array}$ & \multicolumn{1}{c|}{$\begin{array}{c}\text { Außerhalb } \\
\text { der Provinz }\end{array}$} \\
$\begin{array}{l}\text { Einheit } \\
\text { Regelmäßige Meldungen an den Statthalter }\end{array}$ & $\begin{array}{l}\text { Statthalter } \\
\text { Regelmäßiger } \\
\text { Nachrichtenverkehr nach } \\
\text { Rom }\end{array}$ \\
$\begin{array}{l}\text { Statthalter } \\
\text { Nachrichten an einzelne oder alle Einheiten des Provinzheeres }\end{array}$ & \\
$\begin{array}{l}\text { Statthalter } \\
\text { Nachrichten an zivile Verwaltung (procuratores) } \\
\begin{array}{l}\text { Provinziallandtage } \\
\text { einzelne Gemeinden }\end{array}\end{array}$ &
\end{tabular}

Von Rom ausgehende Kommunikation betreffend:
a) Politische Ereignisse (Kaiserhaus, Ernennungen usw.)
b) Administrative Veränderungen (Praefectus praetorio, Statthalter)
c) Einsätze und ihre Planung
d) Versetzungen von Offizieren/Mannschaften
e) Rekrutierungen
f) Beschaffungsmaßnahmen
g) Bauvorhaben

SCHEMA 5.3 Einsatz in der offiziellen Kommunikation.

berittenen Kurier erfolgt sein. Der so ermittelte Ist-Bestand des gesamten Provinzheeres wurde dann durch einen speziellen Boten an die Reichszentrale weitergeleitet. Dies dürfte regelmäßig durch berittene Boten bzw. im Falle der provinciae transmarinae per Schiff erfolgt sein. Auf Grund dieser Informationen wurde dann entschieden, welcher Ersatzbedarf an Rekruten, an Waffen und sonstiger Ausrüstung im letzten Jahr entstanden war und jetzt ersetzt werden mußte. Diese Meldungen bildeten z.B. eine administrative Grundlage für den berühmten libellus, den man nach dem Tode des Augustus vorfand und in dem der aktuelle Zustand des römischen Heeres festgehalten wurde. ${ }^{39}$

39 Suet. Aug. 101.4: .. . tertio breviarium totius imperii, quantum militum sub signis ubique esset, quantum pecuniae in aerario et fiscis et vectigaliorum residuis, “. . . im dritten libellus eine kurze Übersicht über das gesamte Imperium, wie viele Soldaten im Dienst waren und wo sie sich befanden, wieviel Geld sich in der Staatskasse und den Sonderkassen befand und was an Steuergeldern noch ausstand", zusammen mit Tac. Ann. 1.11.3 f.:... cum proferri libellum recitarique iussit. Opes publicae continebantur, quantum civium sociorumque in armis, quot classes regna provinciae, tributa aut vectigalia, et necessitates ac largitiones, "Darauf ließ er einen libellus herbeibringen und vorlesen. Darin waren enthalten, wie viele Bürger und Bundesgenossen unter Waffen standen, wie viele Flotten, Königreiche, 
Diese administrative Routine generierte regelmäßig eine Serie von Schreiben, die von Rom aus an die für eine Rekrutierung ausgewählten Provinzen übermittelt werden mußten, damit diese hinsichtlich des Bedarfs und des Zeitpunktes, bis zu dem die tirones bereitgestellt werden mußten, informiert waren.

Parallel dazu ist von einer weiteren Serie an Schreiben auszugehen, die an das MilitärderZielprovinz gerichtet wurde, damit diese das notwendige Personal für die Überführung der Rekruten abkommandieren konnte. ${ }^{40}$ Für diese Personen mußten Begleitschreiben und Berechtigungsschreiben für die vehiculatio ausgestellt und übermittelt werden. Falls zivile Stellen (Provinz(landtag), Städte) involviert waren, die z.B. ziviles Begleitpersonal delegieren mußten, waren auch hier Aufforderungsschreiben notwendig. Es war daneben ein gesondertes Schreiben an den procurator der Rekrutierungsprovinz notwendig, damit dieser das Geld für das viaticum bereitstellte. Im Fall eines Transportes über See mußten zusätzlich Schiffe organisiert werden, was eventuell durch den Einsatz der lokalen corpora der navicularii geschah.

Da der römische Staat über keine eigenständige Transportflotte verfügte, wurden die notwendigen Schiffe über den privaten Sektor beschafft. Beim Transport über See boten die corpora naviculariorum, die in einem engen Vertragsverhältnis zum Staat standen, die geeignete organisatorische Grundlage. ${ }^{41}$ Beim Flußtransport konnte man die notwendigen Transportschiffe sowohl konfiszieren als auch bei den privaten Eigentümern anmieten (System der locatio conductio operum). Während wir dank der besonderen Quellensituation für die provincia Aegyptus vergleichsweise gut informiert sind, fehlen für die anderen Regionen des Reiches die notwendigen zusammenfassenden Studien zum Einsatz von Schiffen. ${ }^{42}$

In ähnlicher Manier dürften auch offizielle Schreiben in die bevorzugten Produktionsgebiete von Waffen und Kleidung gerichtet worden sein, damit diese informiert wurden, daß sie innerhalb eines festgelegten Zeitraums bestimmte Kontingente produzieren bzw. bereitstellen sollten. Auch in diesen

Provinzen, direkte oder indirekte Steuern, dazu Verbindlichkeiten und Schenkungen es gab."

40 Dies war natürlich nur notwendig, wenn die Rekruten nicht direkt von Personal aus dem Rekrutierungsgebiet begleitet wurden.

41 Vgl. P. Herz 1988, a.a.O. (Anm. 38), 90 ff., 120 ff. Daneben auch L. De Salvo, Economia privata e pubblici servizi nell' impero romano. I corpora naviculariorum (Messina 1992).

42 Ausgangspunkt für Ägypten ist die Arbeit von C. Adams, Land Transport in Roman Egypt. A Study of Economics and Administration in a Roman Province (Oxford 2007). 
Fällen waren schriftliche Aufforderungen für die Transportbegleiter und den zuständigen procurator notwendig.

Zusätzlich ist auch die ständige Information der Einheiten zu berücksichtigen, die in einer Provinz stationiert waren. Dies geschah durch Rundschreiben des Statthalters an die ihm nachgeordneten Einheiten. Beispielhaft dafür ist das folgende Zeugnis. ${ }^{43}$

Marius Maximus trib(unis) et praef(ectis) et praepositis $\mathrm{n}$ (umerorum) salutem.

Quid scripsi Minicio Martiali proc(uratori) Aug(ustorum) n(ostrorum) et notum haberetis adplicui. Opto bene valeatis.

\section{Ex(emplum)}

Curae tibi sit et quaesturas n(umerorum) per quos transit Goces legatus Parthorum missus ad d(ominos) n(ostros) fortissimos imp(eratores) / secundum morem xenia ei offere. Quid autem in quoque numero erogaveris scribe mihi.

Gazica / Appadana / Du[r]a / Ed[da]na / Bi[blade ]

Marius Maximus grüßt die Tribune, Praefekten und Führer der Einheiten. Was ich Minicius Martialis, dem procurator unserer Kaiser, geschrieben habe, habe ich angefügt, damit Ihr es zur Kenntnis nehmt. Ich hoffe, daß es euch gut geht.

Kopie: Kümmere dich darum und auch die Kassenverwaltungen der Einheiten, durch die Goces, der von den Parthern geschickte Gesandte, zu unseren Herren, den allertapfersten Kaisern, fährt, daß ihm entsprechend der Sitte Gastgeschenke überreicht werden. Was aber in welcher Einheit ausgegeben wird, schreibe mir.

(Verteiler): Gazica / Appadana / Dura / Eddana / Biblada.

Ein in seinem Umfang nur schwer zu evaluierender Bereich betrifft die Überstellung von Gefangenen in die Provinzhauptstadt bzw. nach Rom. Der bekannteste Fall ist sicherlich der des Apostels Paulus, obwohl solche Überstellungen auch in Märtyrerakten noch sehr oft erwähnt werden. ${ }^{44}$ Es

43 P. Dura 6o B = Fink 1971, a.a.O. (Anm. 13), Nr. 98.

44 Ob Paulus wirklich auf seinem Weg von Jerusalem nach Caesarea von fast einer kompletten cohors begleitet wurde, wie es die Apostelgeschichte (Act.Ap. 23.23: 200 Infanteristen, 70 Reiter, 200 Leichtbewaffnete) berichtet, erscheint mir fraglich. Dies könnte vom Autor der Apostelgeschichte aufgebauscht worden sein, um die Bedeutung des Apostels hervorzuheben. 
genügt an Bischof Ignatius von Antiochia zu erinnern, der zu seiner Hinrichtung von Syrien nach Rom überstellt wurde. ${ }^{45}$ Bei der Begleitmannschaft dürfte es sich um abkommandierte Soldaten bzw. Offiziere gehandelt haben, die dem jeweiligen Provinzheer entnommen wurden und die wahrscheinlich bereits im Stab des Provinzstatthalters anwesend waren. Daneben müssen wir aber auch noch die Variante berücksichtigen, daß die Aufforderung zur Verhaftung und Überstellung einer Person direkt von der Reichszentrale ausging, die dann auch das notwendige Personal mitschickte.

Ähnlich sieht es beim Wachpersonal für die Überstellung von Gefangenen an ihren Exilort (in insulam) aus. Wenn die hochrangigen Gefangenen direkt von Rom aus verschickt wurden, dürfte diese Aufgabe von Soldaten der cohortes praetoriae erledigt worden sein, die möglicherweise auch als Wachpersonal vor Ort blieben. ${ }^{46}$ Dies allerdings nur in den Fällen, in denen nicht die Zielgemeinde als Kollektiv die Verantwortung für die Überwachung der Gefangenen übernahm. Ähnlich sah es auch bei der Überstellung von Personen aus, die zur Zwangsarbeit verurteilt worden waren, also die Gruppe der in metalla damnati und ihrer anschließenden Bewachung. ${ }^{47}$

\section{$5 \quad$ Konklusion}

Auf der vorläufigen Basis dieser Informationen darf man vermuten, daß in Friedenszeiten wahrscheinlich regelmäßig 25 bis 30 Prozent der nominellen Mannschaftsstärke zumindest der Legionen ständig anderweitig eingesetzt waren und daher nur bedingt für militärische Einsätze zur Verfügung standen.

Um sich eine solche Aussage zu verdeutlichen, kann man von einem idealen Zustand der Einsatzbereitschaft ausgehen, in dem 100 Prozent der Truppe jederzeit verfügbar waren. In einem solchen idealen Falle würden sich alle Soldaten und Offiziere, die nominell zu einer Einheit gehörten, auch wirklich in ihrer Garnison befinden und könnten daher nach einer minimalen Mobilisierungsphase in voller Einsatzstärke ausrücken.

45 Vgl. W.H.C. Frend, Martyrdom and Persecution in the Early Church (Oxford 1965), 197-201. Für den geistigen Hintergrund vgl. C.R. Moss, The Other Christians. Imitating Jesus in Ancient Christian Ideologies of Martyrdom (Oxford 2010), $41 \mathrm{ff}$. Obwohl nicht ausdrücklich gesagt, dürfte Ignatius wahrscheinlich wie Paulus ein civis Romanus gewesen sein.

46 F. Stini, Plenum exiliis mare. Untersuchungen zum Exil in der römischen Kaiserzeit. Geographica Historica 27 (Stuttgart 2011), geht auf die technischen Details kaum ein.

Hirt 2010, a.a.O. (Anm. 37). 
Dabei ist anzumerken, daß das von Th. Fischer vorgestellte Stärkeschema für eine legio kaum haltbar ist. ${ }^{48}$ In diesem Modell werden zusätzlich zu einer vermuteten Einsatzstärke von 4800 Infanteristen und 120 Kavalleristen völlig arbiträre Zahlen z.B. für Handwerker innerhalb der Truppe (400), Beschäftigte bei den verschiedenen Stäben der Einheit (260) oder Abkommandierte zu anderen Stäben oder Aufgaben (610) angesetzt. Im Gegenteil muß man wohl die Masse dieser Männer von der eigentlichen Kampfstärke abziehen, was die wirkliche Einsatzstärke einer solchen legio natürlich entscheidend verringern mußte.

Ähnliche Überlegungen gelten auch für die Soldaten der auxilia. Wenn man z.B. die bedeutende Zahl an Kleinkastellen entlang des obergermanischraetischen Limes nimmt, dann stellt sich ganz natürlich die Frage nach der Herkunft der dort eingesetzten Soldaten. Wenn man nicht Soldaten irregulärer numeri als Besatzung des Limes (Besatzung der Türme, Streckenposten) vermuten möchte, dann können die am Limes eingesetzten Soldaten an sich nur aus den regulären Einheiten der größeren Kastelle in der Nachbarschaft gekommen sein. Dieser permanente Einsatz im Grenzdienst dürfte die Stammbesatzungen dieser Kastelle und damit auch deren weitere Einsatzfähigkeit deutlich beeinträchtigen haben. In vielen Kastellen dürfte daher nur noch eine Rumpfbesatzung zurückgeblieben sein. ${ }^{49}$

Wahrscheinlich konnte man auf römischer Seite diesem Dilemma zwischen der Sicherung der Grenze und der Bereitschaft für einen größeren Einsatz nur begegnen, wenn man einige Einheiten möglichst aus dem eigentlichen Grenzdienst herausnahm. Ich gehe daher davon aus, daß es wahrscheinlich in jedem Provinzheer eine Reihe von Einheiten aus der Gruppe der auxilia gab, die einem höheren Grad der militärischen Einsatzfähigkeit besaßen und die man in Kriegszeiten bevorzugt für Einsätze heranziehen konnte. Dabei würden die verschiedenen alae auch wegen ihrer schnelleren Einsatzfähigkeit die interessantesten Kandidaten für solche Einheiten liefern. ${ }^{50}$

Einer der Gründe, warum eine so hohe Zahl an römischen Soldaten auch in Friedenszeiten außerhalb der Truppe eingesetzt werden mußte, um die zivile Verwaltung und auch die öffentliche Sicherheit zu gewährleisten, ist sicherlich

48 Th. Fischer, Die Armee der Caesaren. Archäologie und Geschichte (Regensburg 2012), 17 nach H. von Petrikovits, Die Innenbauten römischer Legionslager während der Prinzipatszeit (Opladen 1975).

49 H. Bernhard 1990, a.a.O (Anm. 10), 39-168, bes. 89-93 zu den Besatzungen am Limes.

$50 \quad$ Vgl. etwa M.P. Speidel, 'Exploratores. Mobile elite units of Roman Germany', Epigraphische Studien 13 (1983), 63-78, bes. 78 f. = Roman Army Studies II (Stuttgart 1992), 89-104, bes. 96f. zum Einsatz der exploratores Divitenses in Mauretanien. 
in der Grundkonzeption der römischen Herrschaft zu suchen. Neben der römischen Armee existierte auf überregionaler Ebene praktisch keine bewaffnete Autorität, die in der Lage gewesen wäre, im größeren Umfang polizeiliche Aufgaben zu übernehmen. Daher muß man selbst für Italien, also das Kernland des Imperium Romanum, feststellen, daß es z.B. in Unteritalien Regionen mit einer geminderten staatlichen Autorität gab, in denen der römische Staat erst dann intervenierte, wenn die Unsicherheit für die Autorität des Kaisers unerträglich wurde. ${ }^{51}$

Was daher Aelius Aristides in seiner Lobrede auf die Stadt Rom als positive Errungenschaft der römischen Herrschaft hervorhebt, stimmt sicherlich aus der Perspektive eines reichen und gebildeten Vertreters der griechischen Oberschicht in Kleinasien, geht allerdings an den Problemen des Reiches weit vorbei. $^{52}$

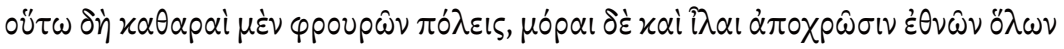

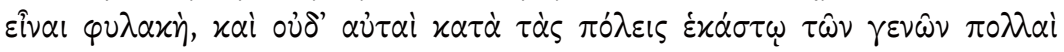

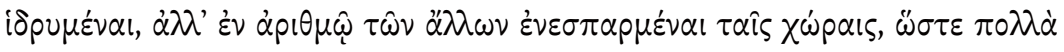

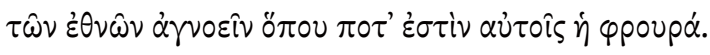

So sind die Städte frei von Besatzungen, Kohorten und Reiterabteilungen genügen zur Beaufsichtigung ganzer Provinzen, und nicht einmal jene sind in größerer Menge auf die Städte der einzelnen Stämme verteilt, sondern sie leben entsprechend der übrigen Bevölkerung verstreut im Land, so daß viele der Provinzen gar nicht wissen, wo ihre Besatzung steht...

Aelius Aristides verstand das Imperium Romanum als ein Reich, in dem Städte und städtisch geprägte lokale Gesellschaften dominierend waren. Er verdrängte damit allerdings die unpassende Erkenntnis, daß die Realität in vielen Regionen des Reiches völlig anders aussah. In diesen Gebieten hatte es das Imperium Romanum bestenfalls in Ansätzen geschafft, eine Struktur zu entwickeln, in denen städtische Gemeinden (und ihre Führungsschichten) einen großen Anteil der Verwaltung übernehmen konnten. Wenn der römische Staat

$5^{1}$ Vgl. M.L. Caldelli, M.F. Petraccia und C. Ricci, 'Praesidia urbis et Italiae. I mestieri della tutela e della sicurezza', in C. Wolff, Hg., Le métier de soldat dans le monde romaine. Actes du cinquième congrès de Lyon organisé les 23-25 septembre 2010 par l'UniversitéJean Moulin Lyon 3 (Lyon 2012), 285-299 zur internen Sicherheit in Italien.

52 Ael. Arist. Orat. 26. 67. Nach R. Klein, Die Romrede des Aelius Aristides, herausgegeben, übersetzt und mit Erläuterungen versehen (Darmstadt 1983). 
also den Anspruch realisieren wollte, in solchen Gebieten seine Herrschaft durchzusetzen, dann war das römische Militär das einzige Machtinstrument, aus das er zurückgreifen konnte. ${ }^{53}$

Es ist das Eingeständnis der traurigen Tatsache, daß die römische Armee an vielen Stellen eingreifen mußte, um die Defizite einer nicht adäquat mit Personal ausgestatteten zivilen Verwaltung auszugleichen, während die eigenen Kräfte kaum ausreichend waren, die militärische Sicherung der Grenzen zu gewährleisten. Kamen dann noch Gebiete wie Iudaea-Palaestina hinzu, in denen sich die römische Herrschaft zusätzlich mit einer internen Opposition konfrontiert sah, dann waren die Probleme fast vorprogrammiert und die militärischen Kapazitäten kamen sehr schnell an ihre Grenzen. ${ }^{54}$

Die in meinem Beitrag vorgestellten Materialien haben die Fragestellung sicherlich nicht erschöpfend behandeln können, sondern sie konnten im besten Falle nur die Grundzüge und auch die potentiellen Erkenntnismöglichkeiten des Themas 'Mobilität des römischen Heeres in Friedenszeiten' aufzeigen. Ich hoffe aber, daß es mir trotz dieser Einschränkungen gelungen ist, die Notwendigkeit und auch den möglichen Ertrag einer ausführlichen Beschäftigung mit einer solchen Fragestellung zu verdeutlichen. Es ist noch viel zu tun!

Regensburg, Silvester 2015

53 Ich greife hier auf einige Überlegungen zurück, die ich an anderer Stelle formuliert habe. Vgl. P. Herz, 'Das Entstehen einer Provinz. Gedanken zum römischen Recht und zur römischen Politik', in U. Lohner-Urban und P. Scherrer, Hg., Der obere Donauraum 50 v.Chr. bis 50 n.Chr. (Berlin 2015), 185-197.

54 Vgl. B. Isaac, The Limits of Empire. The Roman Army in the East (Oxford 1990), 101-16o zur Verteilung der Einheiten und der praesidia. Vgl. auch S.Th. Parker, Romans and Saracens. A History of the Arabian Frontier (Winona Lake 1986) und dens., Hg., The Roman Frontier in Central Jordan. Final Report of the Limes Arabicus Project 1980-1989 I.II (Washington, D.C. 2006). 


\title{
Ordo Senatorius und Mobilität Auswirkungen und Konsequenzen im Imperium Romanum
}

\author{
Werner Eck
}

1 Einleitung

Im Jahr 1984 erschien das von Silvio Panciera herausgegebene zweibändige Werk Epigrafia e ordine senatorio. In Volumen II dieses Werk wurde der Versuch unternommen, durch die Beiträge zahlreicher Autoren einen umfassenden Überblick über die Herkunft der Senatoren aus allen Regionen des Imperium Romanum zu erarbeiten. ${ }^{1}$ Dieser Versuch ist vollinhaltlich gelungen; auch heute noch kann man sich ohne Probleme auf dieser Basis mit der Frage befassen, welche Provinzen zu welchen Zeiten wie viele Senatoren in den stadtrömischen Senat entsandt haben. Die eben publizierten zwei Bände von Epigrafia e ordine senatorio 3 o anni dopo zeigen, ${ }^{2}$ wie grundsätzlich zuverlässig das damalige Ergebnis gewesen ist, trotz der einen oder anderen Veränderung und Ergänzung, die jedoch nicht das Gesamtresultat betreffen.

Somit kann man die Entwicklung der Herkunft der Mitglieder des Senats mit einiger Sicherheit beschreiben. Dabei bleibt die zu Recht immer wieder ausgesprochene Mahnung bestehen, man müsse sich vor $\mathrm{zu}$ sicheren Zahlenangaben hüten. Denn manche unserer Kriterien für die Bestimmung der Herkunft von Senatoren (oder auch Rittern) sind problematisch und deshalb unsicher. Aber - der Gesamttrend ist mit weitgehender Sicherheit beschrieben worden. ${ }^{3}$ Während unter Caesar und speziell unter Augustus vor

1 S. Panciera (Hg.), Epigrafia e ordine senatorio. Atti del colloquio internazionale AIEGL (Roma, 4-20 maggio 1981), 2 Bd. (Rom $1982[1984])=$ EOS.

2 M.L. Caldelli und G.L. Gregori (Hg.), Epigrafia e ordine senatorio 30 anni dopo, 2 Bd. (Rom 2014).

3 Siehe die Zusammenfassung bis in die Mitte des 2. Jh. bei W. Eck, 'La riforma dei gruppi dirigenti. L'ordine senatorio e l'ordine equestre', in A. Schiavone (Hg.), Storia di Roma II, 2 (Turin 1991), 73ff., = 'Die Umgestaltung der politischen Führungsschicht - Senatorenstand und Ritterstand', in W. Eck, Die Verwaltung des römischen Reiches in der Hohen Kaiserzeit. Ausgewählte und erweiterte Beiträge, Bd. 1, herausgegeben R. Frei-Stolba und M.A. Speidel (Basel 1995), 103 ff. Für die spätere Zeit vor allem G. Alföldy, Konsulat und Senatorenstand unter den Antoninen. Prosopographische Untersuchungen zur senatorischen Führungsschicht 
allem die verschiedenen Städte und Stämme Italiens Zugang zum Senat erhielten, zumal auch diejenigen, die im Bundesgenossenkrieg gegen Rom gestanden hatten, ${ }^{4}$ wurden dort bald auch Senatoren von der iberischen Halbinsel und aus der Narbonensis zugelassen, auch wenn die Zahl dieser 'provinzialen' Senatoren zunächst äußerst begrenzt war, über deren Aufnahme vor allem durch die jeweilige politische Situation in Rom selbst entschieden wurde. Der Eintritt von Cornelius Balbus in den Senat und sein Suffektkonsulat im Jahr 40 v.Chr. zeigen diese Abhängigkeit in deutlicher Weise. Doch diese Tendenz hin zu Senatoren aus den Provinzen, also Untertanengebieten des römischen Volkes, verstärkte sich in den folgenden Jahrzehnten, vor allem mit Claudius und seiner programmatischen Rede im Jahr 48 über das sogenannte ius honorum adipiscendorum, das primores Galliae mit einer Gesandtschaft nach Rom beantragt hatten. ${ }^{5}$ Diese Tendenz blieb aber zunächst noch auf den Westen beschränkt. Erst mit Vespasian, der seine Usurpation wesentlich auf die Armeen der östlichen Provinzen stützte, wurden auch die mehr griechisch bestimmten Regionen relativ schnell und prominent im Senat vertreten, obwohl schon vorher einzelne wenige Senatoren bekannt sind, die aus

(Bonn 1977), 61 ff.; P.M.M. Leunissen, Konsuln und Konsulare in der Zeit von Commodus bis Severus Alexander (180-235 n.Chr.). Prosopographische Untersuchungen zur senatorischen Elite im römischen Kaiserreich (Amsterdam 1989), 74 ff.; G. Barbieri, L' Albo senatorio da Settimio Severo a Carino (193-285) (Rom 1952).

4 Klassisch ist die Abhandlung von R. Syme, 'Caesar, the senate, and Italy', Papers of the British School at Rome 14 (1938) 1-31, = in ders., Roman Papers I (Oxford 1979), 88 ff.; siehe ferner T.P. Wiseman, New Men in the Roman Senate, 139 BC-14 AD (Oxford 1971). Zu Oberitalien siehe G. Alföldy, Städte, Eliten und Gesellschaft in der Gallia Cisalpina. Epigraphisch-historische Untersuchungen (Heidelberg 1999), 257 ff.; dazu mit etwas anderer Ponderierung, W. Eck, 'Senatoren und Ritter aus den Städten Italiens nördlich des Po: der Weg der Integration', in G. Cresci Marrone (Hg.), Trans Padum ... usque ad Alpes. Roma tra il Po e le Alpi: dalla romanizzazione alla romanità. Atti del convegno, Venezia 13-15 maggio 2014 (Rom 2015), $130 \mathrm{ff.}$

5 Fr. Vittinghoff, "Zur Rede des Kaisers Claudius über die Aufnahme von "Galliern” in den römischen Senat', Hermes 82 (1954), 348 ff.; G. Perl, 'Die Rede des Kaisers Claudius für die Aufnahme römischer Bürger aus Gallia Comata in den Senat', Philologus 140 (1996), 114 ff.; W. Riess, 'Die Rede des Claudius über das "ius honorum" der gallischen Notablen: Forschungsstand und Perspektiven', Revue des Études Anciennes 105 (2003), 211 ff.; J. Bleicken, 'Zum Regierungsstil des römischen Kaisers, Eine Antwort auf F. Millar', in Gesammelte Schriften II, herausgegeben von F. Goldmann, M. Merl, M. Sehlmeyer und U. Walter (Stuttgart 1998), 843 ff., hier 870 Anm. 70; A. Caballos Rufino, Los Senadores Hispanorromanos y la Romanización de Hispania (Siglos I-III). I: Prosopografía (Écija 1990). 
kleinasiatischen Provinzen stammten. ${ }^{6}$ Die Zahl der von Vespasian in den Senat promovierten Personen aus dem Osten war zunächst noch nicht sehr umfangreich. Doch diese neuen Senatoren, die vor allem unter Domitian reüssierten, zogen schnell andere nach sich, so dass gegen Mitte des zweiten Jahrhundert die Zahl der Senatoren, deren Heimatgemeinde in den griechisch sprachigen Provinzen lag, kaum hinter der aus dem Westen zurückstand. ${ }^{7}$ Und ebenso haben die Senatoren aus den nordafrikanischen Provinzen seit den Flaviern zunehmend eine gewichtige Gruppe dargestellt. ${ }^{8}$ Am Ende des zweiten Jahrhundert war die Mehrzahl der Provinzen im Senat repräsentiert, auch wenn eine Reihe von Regionen des Reiches - jedenfalls nach unseren bisherigen Kenntnissen - dort nicht vertreten waren; zu diesen wohl fehlenden Provinzen gehörten Germania inferior und Britannien, ebenso die meisten Donauprovinzen, aber auch Iudaea und Cypern. Dennoch: der Senat war eine multinationale Versammlung, eine Vertretung führender Familien aus zahlreichen Gemeinden des Reiches geworden, die aber nunmehr alle an einem Ort, in Rom, vereint waren. ${ }^{9}$

Was aber hieß dies für die Mobilität innerhalb des Reiches? Welches waren die Folgen für die Betroffenen selbst, aber ebenso für die Gemeinden, zu deren Bürgern die Senatoren ursprünglich gehört hatten? Diese Fragen sind, wenn ich recht sehe, bisher nicht systematisch behandelt worden, was auch hier nicht umfassend geschehen kann; aber es sollen doch zumindest Hinweise gegeben werden, welche Folgen sich daraus ergaben. Drei Aspekte sollen kurz besprochen werden: Die Folgen der Aufnahme in den Senat für die Heimatgemeinden der Senatoren (Abschnitt 2), der Zwang zur Mobilität als Folge der amtlichen Aufgaben eines Senators (Abschnitt 3), und Rom als Lebensmittelpunkt der Senatoren: die Folgen für die Mobilität anderer Reichsbewohner (Abschnitt 4).

6 Allein aus Perge in Pamphylien sind zwei Senatoren bekannt: M. Plancius Varus und C. Iulius Cornutus Tertullus: W. Eck, 'Vespasian und die senatorische Führungsschicht des Reiches', in L. Capogrossi Colognesi und E. Tassi Scandone (Hg.), La lex de imperio Vespasiani e la Roma dei Flavi (Atti del convegno, 20-22 novembre 2008) (Rom 2009), 231-258. Siehe ferner J. Devreker, 'La composition du sénat romain sous le Flavien', in W. Eck, H. Galsterer und H. Wolff (Hg.), Studien zur antiken Sozialgeschichte. Festschrift Friedrich Vittinghoff (Köln $1980), 257 \mathrm{ff}$.

7 H. Halfmann, Die Senatoren aus dem östlichen Teil des Imperium Romanum bis zum Ende des 2. Jahrhunderts n.Chr. (Göttingen 1979); ders., 'Die Senatoren aus den kleinasiatischen Provinzen des römischen Reiches vom 1.-3. Jahrhundert', in EOS II $603 \mathrm{ff}$.

8 Siehe M. Corbier, 'Les familles clarissimes d'Afrique Proconsulaire (I ${ }^{\mathrm{er}}-\mathrm{III}{ }^{\mathrm{e}}$ siècle)', in EOS II 685 ff.; und M. Le Glay, 'Senateurs de Numidie et des Mauretanies', in EOS II 755 ff.

9 Zu diesem Aspekt in Vorbereitung W. Eck, 'The imperial Senate: Center of a multi-national empire', Kolloquium zu Ehren von B. Isaac, Tel Aviv 26 Mai 2015. 


\section{Die Folgen der Aufnahme in den Senat für die Heimatgemeinden} der Senatoren

Die Aufnahme in den Senat bedingte zwingend, dass nicht nur der Senator selbst seinen Wohnsitz nach Rom verlegte, das von da an auch rechtlich seine Heimat, seine origo, war. Es war auch eine fast zwingende Notwendigkeit, dass die Familie des neuen Senators sich mit ihm nach Rom begab; denn wenn man von den nicht übermäßig zahlreichen Senatoren absieht, die aus Gemeinden in der näheren Umgebung Roms stammten, ${ }^{10}$ dann war unter den Bedingungen der Zeit, falls die Familie am alten Wohnsitz bleiben wollte, die Möglichkeit zur häufigen, gar regelmäßigen Rückkehr in die Heimat sehr begrenzt. Ständige Reisen waren allein deswegen ausgeschlossen, weil jeder Senator vielfältige Verpflichtungen in Rom hatte: Die Anwesenheit bei den Senatssitzungen war obligatorisch, es gab Verpflichtungen religiöser Natur, nicht nur bei den fratres Arvales, auch die Teilnahme an Gerichtssitzungen war erforderlich sowie zumindest die Anwesenheit bei Ereignissen im Kaiserhaus und in den Familien vieler Standesgenossen. Zudem mussten Senatoren, wenn sie in ihre ehemalige Heimat in einer Provinz reisen wollten, um commeatus bitten, zunächst beim Senat, später beim Princeps, außer wenn der familiäre Grundbesitz auf Sizilien bzw. in der Narbonensis lag."1

Der Umzug einer Familie nach Rom hatte einen erheblichen finanziellen Aufwand zur Folge. Denn in Rom musste ein der neuen Stellung adäquater Wohnsitz gefunden werden, meist noch kombiniert mit einem Landgut nicht allzu entfernt vom Zentrum Rom. ${ }^{12}$ Bekannt ist, wie nicht wenige Senatoren, die von der iberischen Halbinsel stammten, solchen Besitz in der Gegend von Praeneste und Tivoli erwarben. ${ }^{13}$

$\mathrm{Ob}$ alle homines novi finanziell so flüssig waren, dass sie eine domus in Rom und eine Villa vor den Toren der Stadt unmittelbar aus ihren finanziellen

10 Siehe die Beiträge von G. Camodeca, M. Cébeillac, M. Torelli, M. Gagiotti und L. Sensi, L. Gasperini und G. Paci, in EOS II; ferner O. Salomies, 'Senatori oriundi del Lazio', in H. Solin (Hg.), Studi storico-epigrafici sul Lazio antico (Rom 1996) 23-127; G. Camodeca, I ceti dirigenti di rango senatorio equestre e decurionale della Campania romana (Neapel 2008).

11 Tac. Ann. 12.23.1: Galliae Narbonensi ob egregiam in patres reverentiam datum ut senatoribus eius provinciae non exquisita principis sententia, iure quo Sicilia haberetur, res suas invisere liceret; Dio 60.25.6f.; Zu all diesen Aspekten R. Talbert, The Senate of Imperial Rome (Princeton 1984).

12 W. Eck, 'Cum dignitate otium. Senatorial domus in Imperial Rome', Scripta Classica Israelica 16 (1997), 162-190.

13 R. Syme, 'Spaniards at Tivoli', Ancient Society 13-14 (1982-3), 241 ff., = in ders., Roman Papers IV (Oxford 1988), 94 ff. 
Rücklagen bezahlen konnten, ist nicht bekannt, was man aber eher bezweifeln darf. Man denke nur daran, dass Plinius d. J. seinen Bekannten Voconius Romanus in den Senat bringen wollte, der jedoch nur mühsam wenigstens das Mindestvermögen nachweisen konnte. ${ }^{14}$ Auch Gavius Clarus, der junge amicus von Cornelius Fronto, konnte nur mit großer Anstrengung die finanziellen Lasten seines Standes bewältigen. ${ }^{15}$ Solche Voraussetzungen hatten notwendigerweise zur Folge, dass nicht wenige neue Senatoren zu Hause Besitz verkaufen mussten, um die flüssigen Mittel in Rom zu investieren, dessen Preisniveaus sicherlich insgesamt höher lag als in Italien oder den meisten Provinzen. Zumindest für einen bestimmten Moment wird dies durch Plinius direkt beschrieben. Denn in dem Augenblick, als Traian die Neuankömmlinge im Senat verpflichtete, ein Drittel ihres Grundvermögens in italischem Grund und Boden anzulegen, wurde, wie Plinius betont, das unterschiedliche Preisniveau deutlich. ${ }^{16}$ Da der Befehl relativ plötzlich kam, entstand eine erhöhte Nachfrage, so dass die Preise für Landgüter vor der Stadt anzogen, während sie in manchen Provinzen wegen des unerwartet hohen Angebots deutlich sanken. Der Preissprung bei Grundstücken wurde auch von denen wahrgenommen, die, wie Plinius d.J., bereits an das normale höhere Preisniveau Roms gewohnt waren. Später verminderte Marc Aurel den Anteil, den Senatoren nach Italien zu transferieren hatten, auf ein Viertel. ${ }^{17}$

Damit ist eine erste Konsequenz erfasst, die die Neuaufnahme eines provinzialen Senators hatte: Da jeder der neuen Senatoren zu Hause zu den ökonomisch Mächtigen oder sogar Mächtigsten zählte, machte sich sein Wegzug in der Heimat bemerkbar, zumindest in der heimischen Ökonomie. Aber auch im Sozialgefüge seiner Heimat konnte das Folgen haben. Denn mit dem Weggang nach Rom war die Familie notwendigerweise in den konkreten städtischen Netzwerken weniger präsent als bisher; sie konnte aber auch ganz ausfallen, es sei denn, sie wirkte diesem möglichen Verlust an Einfluss unmittelbar entgegen. Beispielhaft dafür könnte die Familie der Minicii Natales in Barcino sein. Deren erster bekannter Vertreter, einer der Suffektkonsuln des Jahres 106, ließ zusammen mit seinem Sohn in seiner Heimatstadt ein balineum einschließlich

\footnotetext{
14 Siehe $P_{I R}^{2}$ L 210; R. Syme, 'Pliny's less successful friends', Historia 9 (1960) 362 ff., = in ders., Roman Papers II (Oxford 1979), 477 ff., bes. $480 \mathrm{ff}$.

$15 \quad P I R^{2} \mathrm{G} 97$.

16 Plin. Ep. 6.19.4: eosdem patrimonii tertiam partem conferre iussit in ea quae solo continerentur, deforme arbitratus - et erat - honorem petituros urbem Italiamque non pro patria sed pro hospitio aut stabulo quasi peregrinantes habere. HA. Marc. Aur. 11.8 .
} 
der dafür nötigen Fernwasserleitung erbauen. ${ }^{18}$ In diesem balineum aber hat die Stadt Carthago um das Jahr 153/54 für dessen Sohn, Suffektkonsul im Jahr 139, nach seinem Prokonsulat in Africa eine Quadriga aufstellen lassen, sicherlich mit Zustimmung des Geehrten, vielleicht hat sogar er speziell den Platz vorgeschlagen. ${ }^{19}$ Diese Familie scheint somit in der ehemaligen Heimat auch weiterhin präsent gewesen zu sein, und zwar durchaus gewollt. Man kann dennoch annehmen, dass ihr Platz in der täglichen Politik Barcinos sich deutlich verändert hat und andere Familien und Personen ihre Stellung - mindestens partiell - übernahmen. Auch im pamphylischen Perge lässt sich feststellen, dass die senatorische Familie der Plancii dort weiterhin einen sichtbaren Einfluss ausübte. Zumindest war das Stadtbild des hadrianischen Perge von Plancia Magna geprägt, die auch zahlreiche Ämter in der Gemeinde übernommen hatte. Sie war Tochter des flavischen Senators Plancius Varus und Frau von C. Iulius Cornutus Tertullus, consul suffectus zusammen mit Plinius d.J. im Jahr 10o. Zumindest in ihren späteren Lebensjahren scheint sie auch wieder in Perge gelebt zu haben. ${ }^{20}$

Sicher aber ist, dass die Ökonomie einer Gemeinde von der Aufnahme einer Familie in den Senat betroffen war. Der Transfer zumindest eines Drittels des in Grundbesitz angelegten Vermögens nach Italien kann, wirtschaftlich gesehen, ohne Rückwirkung auf die Heimatgemeinde geblieben sein; denn wenn dieser, vermutlich vor allem landwirtschaftlich genutzte Besitz an andere Eigentümer aus der Gemeinde überging, dann wurde diese dadurch nicht weiter betroffen, weder bei den Steuern, noch bei den mit dem patrimonium verbundenen munera. Doch die Masse des Besitzes eines neuen Senators verblieb notwendigerweise in der Heimat, was schon die traianische Regelung voraussetzt, ebenso aber auch die Nachricht, dass Senatoren ihre Güter auf Sizilien und der Narbonensis ohne Sondergenehmigung besuchen konnten. Selbst wenn Senatoren gewollt hätten, wäre es unmöglich gewesen, den gesamten Besitz nach Italien zu überführen. Auf den Ertrag der in der alten Heimat verbliebenen Güter aber waren die Senatoren, die stets einen gewissen aufwendigen

$18 C I L 2.4509=$ CIL 2. $6145=I L S 1029=$ Inscriptions romaines de Catalogne (Paris 1984), Bd. IV Nr. 30.

19 W. Eck und F.J. Navarro, 'Das Ehrenmonument der Colonia Carthago für L. Minicius Natalis Quadronius Verus in seiner Heimatstadt Barcino', Zeitschrift für Papyrologie und Epigraphik 123 (1998), 237 ff. = AE 1998, 804.

$20 \quad P I R^{2} \mathrm{P}$ 444. Dass sie vielleicht ab Beginn der hadrianischen Zeit, seitdem ihr Ehemann nicht mehr nachweisbar ist, wieder in Perge lebte, lässt sich wohl aus der Dedikation der Statuen der kaiserlichen Familie erschließen: Nerva, Traian und Marciana erscheinen als divi, Hadrian und die Frauen um ihn noch ohne dieses Epitheton. 
Lebensstil führen mussten, in Rom angewiesen. Der finanzielle Ertrag, der auf diesen Gütern erwirtschaftet wurde, war kontinuierlich nach Rom zu transferieren, vermutlich durch diejenigen, die im Auftrag der in Rom wohnenden Senatoren deren Geschäfte in den Provinzen regelten. Dieser Ertrag wurde damit der Wirtschaft eine Provinzstadt entzogen; er wurde dort nicht in den Wirtschaftskreislauf zurückgeführt, weder durch direkten Konsum noch durch irgendeine Form von Investition.

Soweit es sich um den Transfer des Ertrags in monetärer Form handelte, konnte das alles relativ einfach erfolgen und erforderte wenig personellen Aufwand bei der Überführung der Gelder nach Rom. Doch ist zu fragen, ob nicht viele Senatoren gerade Teile der landwirtschaftlichen Produktion nach Rom bringen ließen, statt Lebensmittel wie Getreide, Wein, Öl, die für einen großen Haushalt erforderlich waren, in Rom auf dem Markt zu erwerben. Denn bei großen Haushalten wie etwa dem des Stadtpräfekten Pedanius Secundus, dem allein 400 Sklaven angehörten, ${ }^{21}$ konnte die direkte Versorgung durch den Ertrag der eigenen landwirtschaftlichen Güter ökonomisch vorteilhafter sein. Dazu fehlt uns zwar fast jede Form der Überlieferung; doch liegt der Gedanke unter wirtschaftlichem Kalkül durchaus nahe. Das hätte, wenn viele Senatoren so gehandelt hätten, zu einem nicht geringen Transportverkehr nach Rom geführt, vielleicht weniger aus den überseeischen Provinzen, aber doch zumindest aus den senatorischen Gütern in Italien. Über solche verfügte auch jeder aus den Provinzen stammende Senator spätestens auf Grund der traianischen Regelung, vermutlich aber schon längst vorher. Aber auch über lange Distanzen, auch aus manchen Provinzen können Produkte direkt nach Rom gebracht worden sein. So ist es leicht vorstellbar, dass die Familie der Laecanii ihr Öl und ihren Wein, die sie in Rom brauchten, von ihren Gütern aus Istrien bezog. ${ }^{22}$

Wie auch immer dieser Transfer des wirtschaftlichen Ertrags der provinzialen Güter eines Senators erfolgte, damit war stets ein entsprechender wirtschaftlicher Verlust für die ehemalige Heimatgemeinde verbunden. Für uns ist dieser nicht zu berechnen; doch dass zumindest ein Teil der lokalen Ökonomie und dem städtischen Leben entzogen war, kann man kaum bestreiten. Das galt sogar dann, wenn ein Senator wie Plinius d.J. wiederum einen Teil seines Reichtums zu Hause oder dort, wo er Landbesitz hatte, investierte: in Comum ließ er Thermen und eine Bibliothek errichten, in Tifernum Tiberinum einen Tempel. ${ }^{23}$ Gravierend konnte sich dieser Abfluss aus einer Stadt vor allem

\footnotetext{
21 Tac. Ann. $14 \cdot 42-45$.

22 F. Tassaux, 'Laecanii. Recherches sur une famille sénatoriale d'Istrie', Mélanges de l'école française de Rome. Antiquité 94 (1982), 227 ff. $P_{I R}{ }^{2} \mathrm{P} 490$.
} 
dann auswirken, wenn mehrere Bürger einer Stadt senatorischen Status erhielten, wie z.B. senatorische Familien in Pola, wo Palpellii, Laecanii und Settidii den Schritt in den Senat getan haben, oder auch aus Patavium, von wo noch weit mehr Senatoren stammten. ${ }^{24}$ Hinzu kam noch, dass der Grundbesitz von Angehörigen des Senats eben durch deren Zugehörigkeit zum Senat von bestimmten munera befreit war. Zwar wissen wir nicht, wieweit etwa senatorischer Besitz außerhalb Italiens auch steuerfrei war; sicher ist jedoch, dass die verantwortlichen Munizipalmagistrate nicht das Recht hatten, durchreisende römische Amtsträger oder Soldaten, die durch ein Diplom ihren Anspruch auf kostenlose Übernachtung nachweisen konnten, in Häusern von Senatoren einzuquartieren. Nicht wenige Inschriften aus der Provinz Asia aus der Zeit von Septimius Severus ${ }^{25}$ sowie von Valerian und Gallienus zeigen, dass senatorischer Besitz jedenfalls von diesen munera befreit war. ${ }^{26}$ Das konnte für die anderen Bewohner mancher Gemeinden durchaus spürbare Konsequenzen haben, weil entsprechende Lasten so auf weniger Familien verteilt werden mussten.

Auch wenn man im Detail - zumindest bisher - die vor allem negativen Folgen des Transfers einer Familie in den Senat für die ehemalige Gemeinde nicht nachweisen kann, so scheinen doch allgemeine Überlegungen darauf hinzudeuten, dass diese Folgen nicht gering gewesen sind. Es scheint deshalb nicht abwegig, die Frage zu stellen, ob und möglicherweise wie weit die Schaffung der reichsweiten senatorischen Aristokratie durch einen - neben den allgemeinen Steuern - dauerhaften massiven Abfluss von wirtschaftlichen Ressourcen nach Rom zu einer Schwächung vieler Gemeinden und damit auf längere Sicht einer allgemeinen Schwächung im Reich beigetragen hat.

\section{Der Zwang zur Mobilität als Folge der amtlichen Aufgaben eines Senators}

Die amtlichen Aufgaben der Senatoren waren teils in Rom, weit mehr aber außerhalb der Stadt zu erledigen, in Italien, vor allem aber in den Provinzen. Alle republikanischen Magistraturen wurden weiterhin in Rom ausgeübt,

24 G. Alföldy, 'Senatoren aus Norditalien. Regiones IX, X, und XI', in EOS II 330 f.; 336 ff;; vgl. ders., Städte, Eliten und Gesellschaft in der Gallia Cisalpina. Epigraphisch-historische Untersuchungen (Stuttgart 1999), $283 \mathrm{ff}$., $300 \mathrm{ff}$.

25 CIL 3. 14203, 9; IG 12. 5, 132; I. Eph. 2. 207. 208; AE 1977, 807; TAM 5.1, 607 = W. Eck, Th. DrewBear und P. Herrmann, 'Sacrae litterae', Chiron 7 (1977) 365 .

$26 C I L 3.412=I G R$ 4. $1404=$ W. Eck (Anm. 25), 367 Anm. $53=$ SEG 27, $763=$ G. Petzl, Inschriften von Smyrna (Bonn 1987), Nr. 604. 
womit keine Reisen verbunden waren. Auch einige der erst seit Augustus geschaffenen Funktionen als praefecti frumenti dandi oder praefecti aerarii militaris und Saturni waren in Rom auszuüben, nicht anders als die verschiedenen curae für die opera publica, alvei Tiberis oder aquarum. Doch alle anderen Aufgaben - und das war die übergroße Zahl - mussten außerhalb Roms erfüllt werden. Es war somit für zahlreiche Senatoren fast kontinuierlich nötig zu reisen, um sich dorthin zu begeben, wo sie ihren Aufgaben nachgehen mussten. Seit augusteischer Zeit gingen jährlich in die von Prokonsuln geleiteten Provinzen insgesamt 34 senatorische Amtsträger: Prokonsuln, prokonsulare Legaten und Quästoren. ${ }^{27}$ Rechnet man ihre Begleitung hinzu - darunter allein 72 Liktoren - dann mussten, wenn man scribae, librarii, haruspices und victumarii einbezieht, jedes Jahr allein mehrere hundert Personen in die prokonsularen Provinzen gehen. Nicht eingerechnet ist dabei die private Begleitung der Amtsträger, angefangen von der Ehefrau, häufig auch der Kinder und vor allem der comites, meist Freunden des Senators und schließlich seiner für den persönlichen Dienst nötigen Freigelassenen und Sklaven. Ein Prokonsul von Macedonia hatte im Jahr 164/165 fünfzehn eigene Sklaven in seinem Gefolge. ${ }^{28}$ Wie viele comites einen Prokonsul begleiten konnten, ersieht man etwa an dem Brief des Cornelius Fronto, mit dem er sich bei Antoninus Pius schließlich entschuldigte und erklärte, weshalb er den Prokonsulat in Asia trotz aller Vorbereitungen nicht übernehmen könne. ${ }^{29}$ Jeder Senator, der als Prokonsul eine Provinz leitete, war ein großer Herr, der dies auch durch die Zahl seines Gefolges ausdrückte, ja ausdrücken musste. Der Zahl derjenigen, die sich deshalb mit ihm auf die Reise machen mussten, war folglich entsprechend groß.

Gleiches galt für die Amtsträger in den provinciae Caesaris. Als Calpurnius Piso nach dem Tod des Germanicus endlich im Herbst des Jahres 20 aus Syrien zurückkehrte, wo er Statthalter gewesen war, und am Marsfeld das Schiff verließ, zog er magno clientium agmine ipse, seine Frau Plancina feminarum comitatu in die Stadt, was großes Aufsehen erregte. ${ }^{30}$ Vergleichbares, wenn auch vielleicht in etwas bescheidenerem Maßstab, galt für alle diejenigen, die im

2710 Prokonsuln, 14 prokonsulare Legaten und 1o Quästoren.

$28 A E$ 1965, 205 = AE 1967, 444; neben weiteren Personen, die ihn nach Samothrake begleitet hatten. Man vgl. auch, dass Tac. Ann. 2.80.1 es für erwähnenswert erachtet, Calpurnius Piso habe seine und seiner Frau Plancinas Sklaven für die Aufstellung einer neuen Legion herangezogen. Dann kann deren Zahl, selbst wenn die Aussage des Historikers übertrieben ist, nicht ganz gering gewesen sein.

29 Fronto ad Anton. 2.8 (Van den Hout, p. 166f.).

30 Tac. Ann. 3.9.2; das sind allerdings vermutlich nicht nur die eigentlichen Reisebegleiter, sondern auch die aus der Stadt an den Tiber geeilten Klienten. 
Auftrag des Princeps in seinen Provinzen tätig waren. Schon in augusteischer Zeit waren dies 12 Provinzlegaten, rund 25 Legionskommandeure und ebenso viele tribuni laticlavii, die senatorischen Ranges waren und deshalb ebenfalls im allgemeinen wohl direkt von Rom aus zu ihren Legionen reisten. Unter Marc Aurel hatte sich die Zahl der Legionslegaten und Militärtribune kaum verändert, wohl aber waren es inzwischen 22 senatorische Provinzlegaten, die den Kaiser in den Außenländern des Reiches vertraten. Sie alle blieben zwar länger als ein Jahr an ihre Aufgaben gebunden; aber alle zwei oder drei Jahre hatten sie entweder wieder nach Rom zurückzukehren oder sie gingen direkt in eine andere Provinz, um dort eine weitere Aufgabe zu übernehmen. Und für alle galt, dass sie in ihrer Provinz zwar einen je eigenen Amtssitz hatten; doch ihre Tätigkeit, vor allem als rechtsprechende Magistrate, führte sie an viele Orte einer Provinz, da alle Provinzen das jährlich zu bedienende Konventsystem kannten. ${ }^{31}$ Völlig zu Recht ist deshalb von den 'governors on the move' gesprochen worden. ${ }^{32}$

Letztlich waren zumindest die männlichen Mitglieder des ordo senatorius, aber partiell auch die weiblichen, eine sehr mobile Gesellschaft, beginnend mit der Aufnahme von homines novi in den Senat. Die Mobilität nahm meist im Laufe eines cursus honorum zu und je älter viele Senatoren wurden, desto mehr verbrachten sie ihre Zeit auf Reisen, in ihre Einsatzprovinz und dort sodann entsprechend mit den Reisen zu den Konventsorten oder zu den Lagern der ihnen unterstehenden Truppen. Beispielhaft sei auf Gnaeus Minicius Faustinus Sextus Iulius Severus verwiesen, der 127 zu einem Suffektkonsulat kam. Aus Aequum in Dalmatien stammend, trat er unter Traian in den Senat ein; sein erster Aufenthalt in einer Provinz war durch den Militärtribunat bei der legio XIIII Gemina wohl bereits in Carnuntum bedingt. Wenige Jahre später übernahm er für ein Jahr die Quästur unter einem Prokonsul von Macedonia. Zurück in Rom blieb er dort bis nach der Prätur, als er erneut in Carnuntum nun das Kommando über die legio XIIII Gemina übernahm, etwa in den Jahren von 116-118/9. Von dort ging er vielleicht direkt nach Dacia superior, wo er von 119/120 bis mindestens 126 blieb, um schließlich in den letzten Monaten von 127 als Suffektkonsul zu amtieren, wohl in Rom selbst, nicht in absentia, so darf man zumindest annehmen. Dann folgten drei konsulare Statthalterschaften, zuerst in Moesia inferior, ca. 128-130/131, anschließend in Britannia ca. 132-133, bevor er schließlich die Leitung des Heeres in Iudaea gegen Bar Kochba übernahm. Ob er nach dem Ende dieses Krieges im Jahr 136 auch noch die Provinz

31 Dieses ist jetzt auch für die Provinz Iudaea/Syria Palaestina durch einen noch unpublizierten Papyrus bezeugt (dankenswerter Hinweis von Hannah Cotton).

32 A.J. Marshall, 'Governors on the move', Phoenix 20 (1966) $231 \mathrm{ff}$. 
Syria übernahm, scheint mir unsicher. Doch kehrte er sicherlich wieder nach Rom zurück, um dort auf Antrag des Kaisers und Beschluss des Senats die ornamenta triumphalia zu erhalten. ${ }^{33} \mathrm{Nimmt}$ man alle Jahre zusammen, die er in den Provinzen verbrachte, dann dürften das wohl ca. 22 Jahre gewesen sein. Das war wirklich ein 'senator on the move. ${ }^{34}$ Nicht alle seine Senatskollegen mussten in gleichem Maße bereit sein, sich durchs gesamte Reich zu bewegen wie er. Doch als Grundprinzip galt für die Mehrheit der Senatoren, dass sie für viele Jahre ein unruhiges Leben mit zahlreichen Reisen zu akzeptieren hatten. Bereitschaft zur Mobilität war eine Grundvoraussetzung einer senatorischen Existenz.

\section{Rom als Lebensmittelpunkt der Senatoren: die Folgen für die Mobilität vieler Reichsbewohner}

Dass Senatoren sozusagen durch ihren Status ein mobiles Element innerhalb des Imperiums bildeten, war in der einen oder anderen Form stets bewusst. Kaum wahrgenommen aber wurde bisher, dass die senatorische Existenz, ihr Status und ihre Konzentration in Rom eine vielfache Mobilität anderer Menschen zur Folge hatte. Einige Hinweise auf diese Mobilität als Konsequenz der Konzentration aller Senatoren in Rom mögen hier genügen.

Am 1. Juli des Jahres 153 traten P. Septumius Aper und sein Kollege mit dem langen Namen M. Sedatius Severianus Iulius Acer Metilius Nepos Rufinus Ti.

33 PIR J 576; A.R. Birley, The Roman Government of Britain (Oxford 2005) 129 ff.; W. Eck und A. Pangerl, 'Sex. Iulius Severus, cos. suff. 127, und seine Militärdiplome', Zeitschrift für Papyrologie und Epigraphik 175 (2010) 247 ff., = in W. Eck, Judäa - Syria Palästina. Die Auseinandersetzung einer Provinz mit römischer Politik und Kultur (Tübingen 2014), $245 \mathrm{ff}$. siehe für Sextus Iulius Severus auch Birley S.6o-69 in diesem Band.

34 Ein ähnlich bewegtes Leben hatte ein M. Titius Lustricus Bruttianus, dessen Laufbahn erst seit kurzem bekannt ist: 'Fouilles au forum antique: Marcus Titius, découverte d'un Vaisonnais au sommet de l'Empire', 15. Juli 2015, https://www.facebook.com/notes/vaisonla-romaine/ (letzter Zugriff Dezember 2015). Aus Vasio Vocontiorum stammend hatte er neben zwei Legionskommanden, von denen zumindest eines in die Zeit der traianischen Dakerkriege gehört, Funktionen in folgenden Provinzen zu übernehmen: zweimal in Achaia (als quaestor und als proconsul), in Africa als prokonsularer Legat, als Statthalter in Cilicia, als Legat beim Heer in Germania inferior und superior und schließlich bei den Heeren von Iudaea und Arabia. Die Häduer, deren Patron er war, ehrten ihn in seiner Heimatstadt mit einem großen Monument, vermutlich mit einer Biga (wenn nicht sogar einer Quadriga) - anders als in der im Internet verbreiteten Mitteilung ausgeführt wurde. 
Rutilianus Censor in Rom ihren Suffektkonsulat an. ${ }^{35}$ Sedatius Severianus war kurz vorher aus der Provinz Oberdakien zurückgekehrt, die er etwa ab 150/151 als kaiserlicher Legat geleitet hatte. ${ }^{36}$ Als er in Rom seinen Konsulat antrat, erschien auch eine Gesandtschaft von fünf römischen Bürgern, die der Dekurionenrat der colonia Ulpia Traiana Augusta Dacica Sarmizegetusa ins Reichszentrum gesandt hatte, um dem langjährigen Statthalter zu dieser Promotion in die höchste Rangklasse des Senats die Glückwünsche der Stadt zu überbringen, sicherlich verbunden mit einem Gastgeschenk. Nach ihrer Rückkehr errichteten die fünf Gesandten zum Dank für ihre sichere Reise den dei et numina aquarum einen Altar in Ad Mediam, einem Heilbad, in dem vor allem Hercules verehrt wurde. Warum sie den dei et numina aquarum ihren Dank abstatteten, ist nicht näher ausgeführt; aber dass Gewässer in vielfacher Weise eine Reise beeinflussen konnten, ist leicht vorstellbar. Sie betonen jedenfalls, dass sie incolumes zurückgekehrt seien. ${ }^{37}$

Ob viele Städte der Provinzen in ähnlicher Weise Gesandte nach Rom abordneten, wenn dort ein ehemaliger Statthalter in der senatorischen Hierarchie nach oben befördert wurde, wissen wir nicht. ${ }^{38}$ Unwahrscheinlich ist das freilich nicht, vor allem wenn eine Stadt wie auch im Fall des Sedatius Severianus den Gouverneur zuvor zum Patron der Gemeinde erwählt hatte. ${ }^{39}$ Damit war eine Stadt auch die Verpflichtung eingegangen, dem Patron gegenüber zu zeigen, dass man Ereignisse, die ihn, vielleicht auch seine Familie betrafen, nicht nur beobachtete, sondern soweit nur irgend möglich auch zeigte, dass man zu seiner Klientel gehörte. Das beweisen ja auch mit aller Deutlichkeit die Patronatstafeln, die den Patronen jeweils an ihren permanenten Aufenthaltsort in ihr Haus überbracht wurden, bei Senatoren vor allem

35 Fasti Ostienses zum Jahr 153; vgl. W. Eck, 'Die Fasti consulares der Regierungszeit des Antoninus Pius. Eine Bestandsaufnahme seit Géza Alföldys Konsulat und Senatorenstand', in W. Eck, B. Fehér und P. Kovács (Hg.), Studia Epigraphica in memoriam Géza Alföldy (Bonn 2013) 69 ff., hier 76.

36 I. Piso, Fasti provinciae Daciae I. Die senatorischen Amtsträger (Bonn 1993), $61 \mathrm{ff}$.

37 CIL 3. $1562=$ ILs 3896 (Ad Mediam): Dis et Numinib(us) Aquarum Ulp(ius) Secundinus, Marius Valens, Pomponius Haemus, Iul(ius) Carus, Val(erius) Valens legati Romam ad consulatum Severiani c(larissimi) v(iri) missi, incolumes reversi ex voto.

38 Allgemein zu den Gesandtschaften an Kaiser und Senat in Rom siehe G. Ziethen, Gesandte vor Kaiser und Senat. Studien zum römischen Gesandtschaftswesen zwischen 3 o v. Chr. und 117 n. Chr. (St. Katharinen 1994); C. Habicht, 'Zum Gesandtschaftsverkehr griechischer Gemeinden mit römischen Instanzen während der Kaiserzeit', Archaiognosia 11 (2001/2), $11 \mathrm{ff}$;; W. Eck, 'Diplomacy as part of the administrative process in the Roman Empire', in C. Eilers (Hg.), Diplomats and Diplomacy in the Roman World (Leiden 2009), $193 \mathrm{ff.}$ 
nach Rom. Als die civitas Bocchoritana ex insula Baliarum maiorum im Jahr 10 v.Chr. M. Crassus Frugi, consul ordinarius im Jahr 14 v.Chr., als Patron kooptierte, wurden von der Gemeinde zwei römische Bürger nach Rom gesandt, ${ }^{40} \mathrm{um} \mathrm{ihm}$ die Patronatstafel zu überbringen. Genauso handelte die civitas Lougeiorum aus dem nördlichen Spanien im Jahr 1 n.Chr., die mit Asinius Gallus, einem der Konsuln des Jahres 8 v.Chr., ein Patronatsverhältnis eingegangen war. ${ }^{41}$ Weit aufwendiger war die Gesandtschaft von Zama Regia, als diese Stadt im Jahr 322 n.Chr. einem Q. Aradius Valerius Proculus, ehemals praeses der Provinz Byzacena, die Nachricht überbrachte, man habe ihn zu ihrem Patron erwählt. Zehn Personen machten sich auf die Reise nach Rom, wo die Patronatstafel mit den Namen aller Gesandten die Zeiten überlebt hat. ${ }^{42}$ Auch fünf weitere tabulae patronatus sind dort, obwohl sie aus Metall bestanden, erhalten geblieben; überbracht hatten die afrikanischen Städte Chullu, Thaenae, Hadrumetum, Faustinianensis und Mididi diese repräsentativen Dokumente dem Senator als Zeichen der Zugehörigkeit zu seiner Klientel. ${ }^{43}$ Auch diese Gemeinden traten mit zahlreichen Gesandten auf, im Fall von Chullu hatte sich der gesamte Dekurionenrat auf die Reise nach Italien begeben, unter Anführung der beiden IVviri und der beiden aediles. ${ }^{44}$ Bescheidener war da die Gemeinde Baetulo, der ein einziger legatus genügte, um im Jahr 98 dem Senator Q. Licinius Silvanus Granianus seine Wahl als Patron anzuzeigen. ${ }^{45}$

Wenn man bedenkt, wie viele Patrone manche Gemeinde eingesammelt hat, ${ }^{46}$ dann muss dies zu einem beständigen Verkehr von legati der Städte nach Rom geführt haben, einmal um den Patronatsvertrag mit den hohen Herren abzuschließen und um später die geschaffenen Verbindungen mit solch führenden Personen für die eigene Gemeinde zu nutzen. Denn derartige Verträge hatten durchaus eine konkrete Funktion, die sich im Laufe der Kaiserzeit vor allem in der Vertretung vor dem Kaiser manifestierte. Der Dekurionenrat von

40 Siehe den Text bei C. Veny Mélia, Corpus de las inscripciones Balearicas hasta la dominación arabe (Madrid 1965), 21 = R. Zucca, Insulae Baliares. Le isole Baleari sotto il dominio romano (Rom 1998), 25.

$41 \quad A E 1984,553=A E 1997,862$.

$42 \quad C I L 6.1686=I L S 6111 \mathrm{C}$.

43 PLRE I Proculus 12.

44 CIL 6. 1684: in quam rem gratuitam legationem susceperunt Insteius Renatus et Apollonius Gallentius duoviri, T(itus) Aelius Nigoginus et Aelius Faustinus aediles, L(ucius) Aelius Optatianus Cammarianus, Flavius Secundinus, Domitius Optatianus, Aemilius Nemgonius, Aemilius Titracius, Statilius Secundianus fl(amines) $p($ er $) p($ etui), et unibersus ord $(o)$ $d($ ecurionum $)$.

$45 \quad A E 1936,66$.

46 Vgl. allgemein J. Nicols, Civic Patronage in the Roman Empire (Leiden und Boston) 2014. 
Tergeste machte diese Funktion des aus der Gemeinde selbst stammenden Senators in einem langen Beschluss mehr als deutlich:

uti patriam su[am c] um ornatam tum ab omnib[us] iniuriis tutam defensamque praestaret, interim aput iudices a Cae[sar]e datos, interim aput ip [sum I]mperatorem causis publicis patro[ci]nando, quas cum iustitia divini principis tum su[a] eximia ac [pr]udentissima oration $(e)$ $s[e] m[p e] r$ no $[b]$ is victoria firmiores $r[e]$ misit. ${ }^{47}$

... um seine Heimatstadt in ihrem Glanz zu erhalten und sie vor allen Gefahren und Ungerechtigkeiten zu schützen. Dabei trat er bald vor den vom Kaiser eingesetzten Richtern, bald vor dem Kaiser persönlich in Prozessen, die die Stadt betrafen, als Anwalt auf und durchfocht diese Rechtsansprüche sowohl infolge der Gerechtigkeit des göttlichen Princeps als auch vor allem infolge seiner außerordentlichen und sehr klugen Rede immer siegreich für uns und brachte sie mit größerer Gültigkeit zurück.

Nicht weniger häufig waren Gesandtschaften von Gemeinden, von Collegia, von Heeresabteilungen und natürlich von Privatpersonen, wenn ehemalige Amtsträger in den Provinzen für ihre mehr oder weniger großen Verdienste vor allem durch die Errichtung von Ehrenstatuen geehrt werden sollten, entweder in ihrer Heimatstadt oder - vor allem - in Rom. Wohl in spätrepublikanischer Zeit wurde ein Prokonsul von Pontus-Bithynia in Rom durch acht Städte der Provinz mit einem gewaltigen statuarischen Monument geehrt. Wie der griechisch formulierte Teil des Textes der Inschrift zeigt, war jede Stadt durch einen eigenen Gesandten vertreten. ${ }^{48}$ Bald darauf, wohl in frühaugusteischer Zeit, wollte die Provinz Asia einen jungen, noch keineswegs besonders bedeutsamen Senator, P. Numicius Pica Caesianus, in seinem Haus in Rom mit einer Reiterstatue ehren; dazu ordnete die Provinz insgesamt acht Personen ab, allesamt römische Bürger, die den Auftrag in Rom auszuführen hatten. ${ }^{49}$

47 CIL 5. $532=I L S 6680$. Die folgende Übersetzung nach H. Freis, Historische Inschriften zur römischen Kaiserzeit von Augustus bis Konstantin (Darmstadt 1984), $204 \mathrm{f}$.

48 W. Eck, 'CIL VI 1508 (Moretti, IGUR 71) und die Gestaltung senatorischer Ehrenmonumente', Chiron 14 (1984) $201 \mathrm{ff} .=$ CIL 6. 41054 .

49 CIL 6. $3835=31742=31743=I L S$ 911: $P($ ublio $)$ Numicio $/$ Picae Caesiano $/$ praef(ecto $)$ equitum / VIvir(o) q(uaestori) pro pr(aetore) / provinciae Asiae tr(ibuno) pl(ebis) / provincia Asia // P(ublio) Numicio Picae / Caesiano praef(ecto) eq(uitum) / VIvir(o) q(uaestori) pro pr(aetore) provinc(iae) Asiae / tr(ibuno) pl(ebis) // P(ublius) Cornelius Rufinus C(aius) 
Die Stadt Neapolis in der Provinz Iudaea wollte den Prokonsul der Provinz Asia des Jahres 124-125, Q. Pompeius Falco, an seinem Dienstsitz in Ephesus mit einer Statue ehren; mit der Ausführung des Beschlusses beauftragte sie zwei ihrer Mitbürger, die in der Inschrift unter der Statue genannt sind. ${ }^{50}$ P. Iulius Geminius Marcianus, Legat der Provinz Arabia unter Marc Aurel, wurde von einigen Städten seines Amtsbezirks in Rom mit Statuen geehrt, wobei die Gesandten die Inschriften sogar in griechischer Sprache ausführen ließen; auch ihren eigenen Namen vergaßen die Gesandten nicht. ${ }^{51}$ In frühtiberischer Zeit machten sich die Befehlshaber von fünf Reitergeschwadern, die vermutlich in den Kriegen gegen die rechtsrheinischen Germanen gekämpft hatten, nach Rom auf, um im Auftrag ihrer Einheiten ihrem damaligen Kommandeur P. Cornelius Scipio eine Statue zu errichten, ebenso seinem Sohn Cornelius Orestinus. ${ }^{52}$

Die Reihe solcher Ehrungen in Rom selbst oder auch vielen anderen Städten Italiens und der Provinzen könnte man fast beliebig fortsetzen. Obwohl natürlich die Mehrheit solcher Dokumente verschwunden ist, zeigt die große Zahl der dennoch erhaltenen Dokumente, dass allein wegen der Ehrung von Senatoren, deren üblicher Aufenthaltsort Rom gewesen ist, ein kontinuierlicher Reiseverkehr zwischen Italien und den Provinzen stattfand. Denn keine dieser Ehrungen konnte allein mit einem schriftlichen Auftrag erledigt werden, genauso wenig wie man eine tabula patronatus durch einen Kurier überbringen lassen konnte. Die Aufstellung einer Statue erforderte gewisse Zeremonien nicht anders als die Übergabe der Urkunde, mit der dem erwählten Patron der Beschluss einer Gemeinde in schriftlicher Form überreicht wurde; diese Urkunden schmückten sodann das Haus des Geehrten, vermutlich im Eingangsbereich, um allen Besuchern den konkreten Rang der Person deutlich zu machen. Im Haus des Q. Aradius Valerius Proculus haben mindestens sechs solcher tabulae von den Wänden des Atriums herab den Besuchern

Autronius Carus / L(ucius) Pomponius Aeschin(es) Sex(tus) Aufidius Euhodus / Q(uintus) Cassidienus Nedym(us) T(itus) Manlius Inventus / C(aius) Valerius Albanus Sex(tus) Aufidius Primigen(ius) / patrono; W. Eck und H. v. Hesberg, 'Tische als Statuenträger', Mitteilungen des Deutschen Archäologischen Instituts. Römische Abteilung 111 (2004 [2006]) $143 \mathrm{ff}$.

$A E$ 1972, 577 = I. Eph. 3. 713; dazu W. Eck, 'Flavius Iuncus, Bürger von Flavia Neapolis und kaiserlicher Prokurator. Gedenkschrift zu Ehren von U. Vogel-Weidemann', Acta Classica 42 (1999), 67 ff. = ders., Judäa - Syria Palästina. Die Auseinandersetzung einer Provinz mit römischer Politik und Kultur (Tübingen 2014), 74 ff.

$5^{1} \quad P_{2}^{2}$ J 340; D. Erkelenz, Optimo praesidi (Bonn 2003), 223; 269.

$5^{2} \quad$ CIL 6. 41050 . 
vor Augen geführt, welch hochangesehener Mann in diesem Haus lebte. ${ }^{53}$ Und im Park der Q. Glitius Atilius Agricola in Augusta Taurinorum standen mindestens neun Reiterstatuen, dediziert von Gemeinden aus mindestens drei Provinzen des Reiches, in denen Agricola amtiert hatte. ${ }^{54}$ Es ist gar nicht anders möglich, als dass die Gesandten bei all den Dedikationen anwesend waren, um schließlich nach ihrer Rückkehr darüber Bericht erstatten zu können. Jede Statuenweihung war mit einem 'Fest' verbunden. ${ }^{55}$

Dies sind nur wenige Hinweise darauf, welche Konsequenzen daraus erwuchsen, weil die Senatoren, die zunehmend aus den Provinzen stammten, normalerweise in Rom und in Italien lebten, zumindest ihre Familien. Die einzelnen Senatoren blieben, trotz des stetig voranschreitenden Bedeutungsverlustes des Senats als Institution, ein wesentliches Element im politisch-sozialen Leben des Reiches. Ihre Reisen und die Reisen vieler anderer zu ihnen zeigen dies mit banaler Deutlichkeit.

Köln, November 2015

\footnotetext{
53 Siehe oben Anm. 42-44.

54 Eck und Hesberg 2004, (Anm. 49).

55 Dazu W. Eck, 'Einladung zum Fest in der Stadt', in Urbanitas - Urbane Qualitäten, Kolloquium zu Ehren von Hennerv. Hesberg, München 19.12.2012-21.12.2012 (im Druck).
} 


\title{
Diplomatic Mobility and Persuasion between Rome and the West (I-II AD) ${ }^{1}$
}

\author{
Elena Torregaray Pagola
}

\section{1 Introduction}

Part of Augustus' discourse in the Res Gestae reviews the numerous legationes-embassies he received. Their mention served to mark the borders of the empire and to highlight its vastness. ${ }^{2}$ Yet, from the viewpoint of what could be considered as Rome's international relations, a new phase was actually set during which the intensity of diplomacy between Rome and the various communities it was related to (as a result of territorial expansion), as well as Rome's control over her boundaries, considerably decreased. The peak of diplomatic exchange had been reached in the Republican period in the second century BC. It noticeably declined from the first century вС onwards. Within the empire, once the conquest was completed, political communication with Rome was arranged differently. This, at any rate, is the viewpoint of modern historiography which makes a clear distinction between diplomacy, as a tool of external relations between sovereign states on the one hand, and political communication, intended at shaping internal relationships within a state on the other. ${ }^{3}$ However, from a Roman point of view, at least in terms of wording, the situation did not change much as Romans did not differentiate between diplomacy and political communication: to them it invariably consisted of the dispatch of a legatio, a mission. ${ }^{4}$ This approach, closer to modern considerations

1 This research has benefited from funds from MINECO HAR2013-42615-P.

2 RG 31-33. C. Nicolet. L'Inventaire du monde: Géographie et politique aux origines de l'Empire romain (Paris 1988).

3 The term 'political communication' referring to the internal diplomacy in the Roman empire has been extracted from A. Gillett, Envoys and Political Communication in the Late Antique West 411-533 (Cambridge 2003).

4 F. Millar, 'Government and diplomacy in the Roman Empire during the first three centuries', The International History Review 10 (1988), 345-377; G. Ziethen, Gesandte vor Kaiser und Senat. Studien zum römischen Gesandtschaftswesen zwischen 30 v. Chr. und 117 n. Chr. (St. Katharinen 1994), 1-6; J. Edmonson, 'The Roman Emperor and local communities of the Roman Empire', in J.-L. Ferrary and J. Scheid, eds., Il princeps romano: autocrate o magistrato? Fattori giuridici 
of the transnational nature of external relations whereby the internal and external policy of a state do not differ, should nonetheless be qualified. Such a differentiation did not actually apply within the Roman empire. This might lead us to question the existence of a genuine external policy in Rome and possibly to consider the term 'policy' itself quite anachronistic.

Apart from these preliminary considerations of terminology, what is undeniable is that since the war against Pyrrhus, and even more so since the Second Punic War, a new pattern of diplomatic mobility can be detected in the Mediterranean. It is linked to the rise of Rome's centrality. All those communities wishing to negotiate or ratify their submission to Rome began to send embassies to the city. It generated a constant flow that over time came to alter the capacity to receive within the city itself. The flow was constant and regular from the second century вС onwards. It amplified the previous movement taking place in the theatres of conquest, when the Roman general redirected the embassies sent to him to the central point from which the military campaign was organized-usually his camp. These lesser movements established in the area of conquest were replaced by a larger flow aimed at the city of Rome. Thus Rome organized diplomatic mobility, attracting a large number of embassies in February, the month appointed by the Senate for their reception during the Republic. In all likelihood the official date of February, established already in the lex Gabinia, had an impact on the travelling arrangements of ambassadors, who sometimes had to face a long journey, in order to reach the city in time. Under the empire, the reception procedure was altered since the main objective of the legationes was to be received by the princeps. ${ }^{5}$ Dates were therefore altered and concentrated in the summer and autumn. The location of the reception was no longer strictly limited to the city of Rome, but to wherever the princeps happened to be. However, the pattern of diplomatic mobility in imperial times continued to be aimed largely at the city of Rome.

Nevertheless, the mobility of people concerned with political communication and diplomacy did clearly decrease from the late first century вс onwards. Rome sent out hardly any envoys and limited itself to receiving legationes from cities and provinces. G. Souris observed on the basis of attestations in the epigraphic sources that the embassies cluster in the early stages of the Principate,

e fattori sociali del potere imperiale da Augusto a Commodo. Istituto Universitario di Studi Superiori (Pavia 2015), 127-129.

5 C.D. 53. 21. 6; 33.1-2. F. Hurlet, 'Les ambassadeurs dans l'Empire romain. Les légats des cités et l'idéal civique de l'ambassade sous le Haut-Empire', in A. Becker-Piriou and N. Drocourt, eds., Ambassadeurs et ambassades au cœur des relations diplomatiques. Rome-Occident médiévalByzance (VIII ${ }^{e}$ s. av.J.-C.-XII ${ }^{e}$ s. ap.J.-C.) (Metz 2012), 110-118. 
with Augustus and then Claudius receiving the most. ${ }^{6}$ Later in the imperial period, the bulk of diplomatic communication occurs in the second century $\mathrm{AD}$, in the Antonine period, while its volume drastically diminished in the first half of the third century AD.

Were we to outline a map of diplomatic mobility within the territory of the empire, a clear difference in terms of the provenance of legationes can be observed. Arrivals from western provinces were notably fewer than those from the eastern zone of the empire. ${ }^{7}$ Such a disparity, however, is no novelty compared to the Republican period, when it was even more pronounced. ${ }^{8}$ The works of F. Canali de Rossi, detailing the number of embassies sent from the Greek world to Rome in the Republic, clearly show much higher diplomatic mobility in this area than in the west. In this sense, there is continuity in terms of diplomatic practice within the Roman system between the Republic and the empire. Different diplomatic cultures, much more developed in Hellenic territories than in the west, unquestionably had an influence on this unequal distribution and the mobility of legationes. The usual practice of sending embassies, widespread in the Greek world in classical and Hellenistic times, continued throughout the Republican and imperial periods. It was a fully established means of communication and its goals simply needed to be redirected after the Roman conquest. In the west, however, this procedure was relatively new. Literary sources seem to claim it responded to necessity and was much more local and circumstantial than in Greek diplomatic practice. For instance, Massilia, a Greek city in the west, maintained abundant diplomatic relations with Rome during the Republic, attesting to a diplomatic culture linked to Greek tradition rather than to western practices. This distinctive behaviour of the east and the west in terms of diplomatic mobility persisted during the

6 G. Souris, Studies in Provincial Diplomacy under the Principate (diss. Cambridge 1984), 78.

7 C. Habicht, 'Zum Gesandtschaftsverkehr griechischer Gemeinden mit römischen Instanzen während der Kaiserzeit', Archaiognosia 11 (2001/2002), 11-28; W. Eck, 'Diplomacy as a part of the administrative process in the Roman empire', in C. Eilers, ed., Diplomats and Diplomacy in the Roman World (Leiden and Boston 2009), 193-208.

8 F. Canali de Rossi, Le ambascerie dal mondo greco a Roma in età republicana (Rome 1997); E. Torregaray Pagola, 'Embajadas y embajadores entre Hispania y Roma en la obra de Tito Livio', in idem and Y. Santos Yanguas, eds., Diplomacia y autorrepresentación en la Roma antigua (Vitoria-Gasteiz 2005), 25-62; A.M. Sanz, 'Rome et les communautés hispaniques: des ambassadeurs face à l'émergence d'un pouvoir hégémonique (fin $\mathrm{III}^{\mathrm{e}}-\mathrm{II}^{\mathrm{e}}$ siècle av. J.-C.)', in A. Becker-Piriou et N. Drocourt, eds., Ambassadeurs et ambassades au coeur des relations diplomatiques. Rome-Occident médiéval-Byzance (VIII ${ }^{e}$ s. av. J.-C.-XII ${ }^{e}$ s. ap. J.-C.) (Metz 2012), 31-63; E. García Riaza, 'Legati ad Caesarem. Instituciones diplomáticas indígenas en el “Bellum Gallicum”, Veleia 26 (2009), 47-62. 
empire, probably due to diverse traditions. Nonetheless inscriptions register a slight increase in the number of tributes to ambassadors from the second century AD onwards in the west, which may indicate that these communities too started to regard diplomatic service as a source of honour for their city notables.

Following W. Eck and F. Hurlet, it might be claimed that the initiative to send embassies to the princeps in the west was conditioned by mediation of officials in power, such as the provincial governor. ${ }^{9}$ They could exert great influence in the final decision of dispatching a legatio, which usually would be based on practical issues which were mostly economic. Nonetheless I believe that we need to take into consideration the fact that western communities were immersed in forms of diplomacy whereby relationships with the centre of the Roman empire revolved around models laid down by the different imperatores from the time of the conquest, based on what they viewed as less developed diplomatic tools than their own. In this sense Rome dealt differently with the east by implementing the existing diplomatic culture and adapting to it. As a result, during the empire, eastern communities took the initiative when sending embassies to the princeps.

Diplomatic Mobility in the West

An analysis into the dispatch of embassies from the western territories of the empire must take into consideration in the first place why these envoys were sent. As legationes were part of a process of self-representation of the community, their typology is intimately linked to the new role attributed to western provinces in Rome's imperial structure both from the viewpoint of administration and ideology. ${ }^{10}$ Thus, a communication policy developed from the first to the third century $\mathrm{AD}$ in which relationships mostly revolved around the figure of the princeps-though embassies were also sent to the Senate or the provincial governor in an attempt to relieve the emperor's workload-and representatives of local and provincial administration. Once Roman administration and management were settled after military conquest, the purpose of most of

A. Bérenger, 'Les relations du gouverneur avec les notables provinciaux: cérémonial et sociabilité, in N. Barrandon et F. Kirbihler, eds., Les gouverneurs et les provinciaux sous la République romaine, (Rennes 2011), 171-187; Idem, Le métier de gouverneur dans l'empire romain (Paris 2014), 367-401.

10 Hurlet 2012, op. cit. (n. 5), 101-126; J.F. Rodríguez Neila, 'Las legationes de las ciudades y su regulación en los estatutos municipales de Hispania', Gerión 28 (2010), 223-273. 
the known legationes was to acknowledge the figure of the emperor and to deal with local administrative issues. ${ }^{11}$ They fulfilled a dual objective: loyalty to the princeps was displayed, but at the same time the praise and the journey, far from being pointless, were used for the benefit of their community. This was a game of recognition of power, exhibited in the praises uttered by the legati and also a display of the princeps' generosity and euergetism. ${ }^{12}$

Bearing this in mind, it can be argued that most of the known legationes attested in literary and epigraphic sources consisted of expressions of loyalty to the princeps from the western territories. Because of this fact, it must also be pointed out that these are all successful legationes. The possible failures in political communication between the two parties, which probably did occur, are practically unknown to us. ${ }^{13}$

Furthermore, the recorded legationes, beyond their political aim, contributed to the design of a specific image of the empire supporting the historicalliterary construction of an unambiguous image of the emperor. Quite probably, though not certainly, by comparison with what happened in the east, the definition of the relationship of the city with the princeps played a prominent role in the agenda of the main municipal and provincial assemblies in the west. ${ }^{14}$ In consequence, both the petitions the city wished to put before the emperor must have been dealt with as well as the necessary acknowledgement of events concerning the imperial rule, births, deaths, successions, celebration of victories, etc. The city or the province sought to demonstrate its loyalty, but it was also necessary to establish good relations which could later procure benefits for the community.

In terms of chronology, literary and epigraphic sources recording political communication between the western territories and Rome during the empire notably accumulated in the Julio-Claudian period, slightly decreased during the Flavian dynasty and increased again during the Antonine period, the first and last being the most abundant, possibly because these were times of reinforcement of the imperial institution. There is also a clear difference between

11 F. Millar, The Emperor in the Roman World (31 BC-337 AC) (London 1977), 218; F. Kayser, 'Les ambassades alexandrines à Rome (I-II siècle)', Revue des Études Anciennes 105 (2003), 440.

12 T.R. Stevenson, 'The ideal benefactor and the father analogy in Greek and Roman thought', Classical Quarterly 42.2 (1992), 421-436.

13 T. Corey Brennan, 'Embassies gone wrong: Roman diplomacy in the Constantinian Excerpta de Legationibus', in C. Eilers, ed., Diplomats and Diplomacy in the Roman World (Leiden and Boston 2009), 171-192.

14 H. Fernoux, Le demos et la cité: Communautés et assemblées populaires en Asie Mineure à l'époque impériale (Paris 2011), 275. 
the types of sources. Literary sources are more abundant in the Julio-Claudian period, coinciding with the evident tribute historiography pays to the recently created and established imperial institution, while in the Flavian and Antonine period in the west, epigraphic testimonies are more abundant regarding legationes, which might confirm the trend towards greater interaction between the parties within the system and the increased efficiency of local and provincial institutions, who dispatched legationes to the princeps. ${ }^{15}$

An analysis of the corpus of documents reveals immediately that in the Julio-Claudian period, Augustus and Claudius were the emperors who received the highest number of legationes from the west and, in general, from the entire empire. ${ }^{16}$ The concentration of embassies sent to these emperors is, without a doubt, the result of the need to receive extraordinary legitimacy both from the founder of the Principate and his successors. All of the embassies sought to differing and varying extents to demonstrate the loyalty of the western provinces towards the emperor. They revolved around three topics.

Firstly, the gifts presented in acknowledgment of the victories of the empire, presumably contributions to the glory of Rome thanks to the princeps, directly linked to the Republican custom of sending embassies of congratulations to the Senate for Rome's military triumphs. ${ }^{17}$ It might be considered an extension of the practice of the diplomatic gift, also in the Republican period, which included the habit of depositing gifts in the temple of Capitoline Jupiter acknowledging his superiority. Amongst those offered by western embassies, the most relevant are the gifts made to Augustus by Baetica, ${ }^{18} \mathrm{Gallia}$, the municipia and the colonies of Italy ${ }^{19}$ and to Claudius by the provinces of Hispania

15 S. Panzram, Stadtbild und Elite: Tarraco, Corduba und Emerita Augusta zwischen Republik und Spätantike (Stuttgart 2002), 55-57, 167, 223.

16 Souris, op. cit. (n. 6), $78-79$.

17 C. Auliard, 'Cadeaux et merchandages diplomatiques à Rome jusqu'au début de la conquête méditerranèenne', Veleia 26 (2009), 63-74.

18 CIL 6. 31267; E. Torregaray Pagola, 'Legationes cívicas y provinciales: la comunicación política entre "Hispania” y Roma en época imperial', in E. Ortiz de Urbina, ed., Los magistrados locales de Hispania: aspectos históricos, jurídicos, lingüísticos (Vitoria-Gasteiz 2013), 317-319.

19 For Italy, see $R G$ 21: Auri coronari pondo triginta et quinque millia municipiis et colonis Italiae conferentibus ad triumphos meos quintum consul remisi, "In my fifth consulship I remitted thirty-five thousand pounds weight of coronary gold contributed by the municipia and the colonies of Italy". For the Gauls, see Quint. Inst. 6.3.79: Sed eluditur et ridiculum ridiculo ut diuus Augustus, cum ei Galli torquem aureum centum pondo dedissent..., "But a joke may be evaded by a joke: the emperor Augustus was given a golden torque weighing a hundred pounds by the Gauls ..."; Ziethen 1994, op. cit. (n. 4), 245. 
citerior and Gallia Comata, which sent gold crowns to commemorate his victory over Britannia. ${ }^{20}$ All these embassies demonstrated public loyalty to the imperial institutions by acknowledging Rome's military might.

Secondly, embassies linked to family events concerning the emperor, such as the approval by Augustus of funeral honours decreed by Pisa for Lucius and Gaius, or the sending and reception of the senatusconsultum concerning the funeral honours related with Germanicus, ${ }^{21}$ or the condolences arriving from Gaul on the death of Nero's mother, Agrippina. ${ }^{22}$ The ultimate purpose of such embassies was to establish a form of partaking in the common grief, thus consolidating the imperial structure.

Thirdly, legationes concerning the institution of the imperial cult which, like the second category, renewed the links of adhesion to the princeps from a religious viewpoint. ${ }^{23}$ Generally, this type of embassy focused on petitions to build temples in honour of the emperor. ${ }^{24}$ In the case of Hispania, both Baetica and Hispania citerior dispatched petitions in the Julio-Claudian period to build temples dedicated to the cult of the emperors, demonstrating an early adoption of such practices. ${ }^{25}$

The aforementioned instances of construction of temples, condolences and congratulations for a triumph presented a specific model of loyalty to the figure

20 Plin. NH. 33.16.54: Claudius successor eius, cum de Brittannia triumpharet, inter coronas aureas VII pondo habere quam contulisset Hispania citerior, VIIII quam Gallia comata, titulis indicauit, "His successor Claudius when celebrating a triumph after the conquest of Britain, advertised by placards that among the gold coronets there was one having a weight of 7000 pounds contributed by Hither Spain and one of gooo from Gallia Comata"; Rodríguez Neila 2010, op. cit. (n. 10), 229.

21 CIL 11. 1420.33-37: '... legati ex nostro ordine ...'; 1421.42; Tab. Siar. 2b. 24-26. Rodríguez Neila 2010, op. cit. (n. 10), 226.

22 Quint. Inst. 8.5.15: Et insigniter Africanus apud Neronem de morte matris: "rogant te, Caesar, Galliae tuae ut felicitatem tuam fortiter feras", "Another distinguished example is Africanus' remark to Nero about his mother's death, 'Caesar, your provinces of Gaul beg that you will bear your happiness like a man'”; Ziethen 1994, op. cit. (n. 4), 245; Rodríguez Neila 2010, op. cit. (n. 10), 228-229.

23 D. Fishwick, The Imperial Cult in the Latin West. Studies in the Ruler Cult of the Western Provinces of the Roman Empire. Vol. 3 (Provincial Cult) (Leiden 2002).

24 B. Pouelle, 'Religion et récit historique: les ambassades des sanctuaires grecques sous Tibère (Tacite, Annales III.6o-63)', Dialogues d'Histoire Ancienne, suppl. 4.2 (2010), 343-350.

25 Tac. Ann. 4.37-38; Suet. Tib. 31; Tac. Ann. 1.88.1; Quint. Inst. 6.33.77; W.E. Mierse, Temples and Towns in Roman Iberia. The Social and Architectural Dynamics of Sanctuary Designs, from the Third Century BC to the Third Century AD (Berkeley CA etc. 1999), 54-128. 
of the princeps, confirming the image provided by the literary sources of adhesion and fidelity of the provincial and local communities involved.

After the Flavian reorganization, the perfecting of Rome's administrative system accelerated and advanced. Sources-which become mostly epigraphic-regarding the practice of sending legationes and political communication give more information about administrative interaction between the parties, recording more than simply the devotion displayed by provinces and cities towards the princeps. Due to this, from the Flavian period onwards information is available regarding legationes dealing with specific issues in the development and administration of cities. ${ }^{26}$ Interaction between the participants as well as a greater concern about management become more prominent. The texts thus no longer deal simply with the adulation of the emperor as a conqueror or pacifier but also emphasize his role as organizer and manager of the empire. An example of this change in the terms of political communication can be found in the letters sent by Vespasian and Titus to Sabora ${ }^{27}$ and Munigua, ${ }^{28}$ respectively. They reflect the intervention of the princeps in matters concerning the management of the cities, which are the result of the respective legationes dispatched with the purpose of receiving the favours of both emperors. ${ }^{29}$

The continuous renovation of the imperial institution was further boosted by the coming to power of the Antonines. In this period, the number of received legationes increased, no doubt in order to renew commitment to the empire. Preserved documentation continues to be mostly epigraphic and reveals a flow of political communication in continuity with former practices. Antoninus Pius and Hadrian are now the emperors receiving the most embassies. ${ }^{30} \mathrm{We}$ also know that Hadrian was one of the few emperors who, like Augustus, personally travelled to the Iberian peninsula around the years $122-23 \cdot{ }^{31} \mathrm{He}$ spent the winter in Tarraco, as did his predecessor, and, according to the Historia Augusta, it was to this place that he called the inhabitants of Spain, probably

26 P. Le Roux, La Péninsule Ibérique aux époques romaine (206 avant J.-C-4og ap.J.-C.) (Paris 2010), 126-127.

27 CIL 2/5. 871 = ILS 6o92; J. González, Bronces jurídicos romanos de Andalucía (Sevilla 1990); A. D’Ors, Epigrafía jurídica de la España romana (Madrid 1953) 61-63, n. 4.

28 HAE (Hispania Antiqua Epigraphica), 12-16, 1923 = AE 1962, 288. González 1990, op. cit. (n. 27), 169-170, n. 13; Rodríguez Neila 2010, op. cit. (n. 10), 230.

29 Eck 2009, op. cit. (n. 7), 193-195.

$30 \quad$ Souris 1984 , op. cit. (n. 6), 78-79.

$31 \quad C I L 2.4201=R I T 331=I L S$ 6927; Le Roux 2010, op. cit. (n. 26), 132-133. 
driving the movement of many legationes from different places of Hispania to the capital of the province Citerior. ${ }^{32}$

From the Antonine period onwards, advances were made in forms of political communication. In preserved documentation, mostly epigraphic, greater prominence is given to the legati rather than to the princeps. Tributes paid to them for their 'diplomatic' endeavour now provide most information about legationes. They confirm the increasing significance attached to the notables in the cities and to representatives of the provincial assembly presenting their initiatives to the emperor. But one of the most meaningful aspects of these homages from the point of view of diplomatic practice in the empire is the fact that the usefulness of embassies is measured in terms of the success of their dealings. In some inscriptions recording embassies coming from Hispania and Africa the idea that prosperitas is an essential element attached to the legatio is highlighted, ${ }^{33}$ as well as the utilitas for and the satisfaction of the community, from the successful dealings carried out by the embassy. While conclusions are obviously qualified by the hazards of preservation of available documents, it seems clear that the level of success of the mission constituted an indispensable element in the public perception of the usefulness of legationes dispatched from the western territories to Rome or to an audience with the emperor.

At this point, we might ponder the aforementioned difference in the amount of embassies sent by the western territories compared to those sent from the east. A passage in Suetonius' biography of Tiberius describes the difficulties that some ambassadors from Africa-legati ex Africa-experienced in being received by the princeps, causing an unnecessary and unwanted delay in their dealings. Although the passage is ironic about Tiberius, Tacitus as well shows the emperor leaving diplomatic affairs - from the east—in the hands of the

HA, Hadr. 12, 3-4: Omnibus Hispanis Tarraconem in conuentum uocatis dilectumque ioculariter, "To this place, too, he called all the inhabitants of Spain for a general meeting, and when they refused to submit to a levy..."; Aul.Gel. NA 16. 13. 4: De cuius opinionis tam promiscae erroribus diuus Hadrianus in oratione, quam de Italicensibus, unde ipse ortus fuit, in senatu habuit, peritissime disseruit mirarique se ostendit, quod et ipsi Italicenses et quaedam item alia municipia antiqua, in quibus Vticenses nominat, cum suis moribus legibusque uti possent, in ius coloniarum mutari gestiuerint, "With regard to the errors in this opinion which is so general the deified Hadrian, in the speech which he delivered in the senate On Behalf of the Italicenses, from whom he himself came, discoursed most learnedly, showing his surprise that the Italicenses themselves and also some other ancient municipia, among whom he names the citizens of Utica, when they might enjoy their own customs and laws, desired instead to have the rights of colonies". 
consuls, thwarting the initial objective of the embassy of dealing with him. ${ }^{34}$ In this case, there is no difference between east and west, but it is possible that the difficulty of reaching the emperor added a complication to sending legationes from the west, whose diplomatic practice was weaker. Taking into consideration the expense for legati to stay in Rome or wherever the princeps might have been at the time, it is plausible that pressure for success and straightforward access to the emperor where crucial issues when deciding to dispatch embassies by the western local and provincial assemblies. ${ }^{35}$ Lobbies are widely known to have existed in Rome from the Republic onwards. They strove to help diplomatic missions seeking support from the most prominent politicians in the city. However, their presence might also have hindered the work of ambassadors whose endeavours perhaps did not meet a satisfactory conclusion, at least within a relatively short period of time. In this respect, G. Souris's thesis regarding western legationes stipulating that it was generally embassies from large and prestigious cities that were easily granted access to the emperor and that only those communities who held some significance for the emperor were received by him, could at least partially explain the scant movement of western embassies within the imperial period. Many of these embassies were redirected to other officials, a practice which could compromise their effectiveness. ${ }^{36}$ Against a background where probably the laudatio to the princeps included in any legatio had to be replied to by a munificent action from the emperor or with a sign of favour or benevolence towards the applicants, it was extremely important to secure a direct interview with the emperor. Failure to do so could almost be considered a failure of the legatio. It would be reasonable to believe that the emperor himself, on some occasions, would avoid receiving ambassadors so as to deter further missions. This is the reason why the preserved tributes, some of which contain an acknowledgement of success, may not have referred solely to the outcome of negotiations but to the fact of having managed to reach the princeps himself. ${ }^{37}$

The suggestion of W. Eck that western communities eventually found it much more efficient to resort to the provincial governor rather than taking on the costly effort of dispatching a legatio to the emperor is therefore plausible. Such a practice might be connected with the formula used in a series of diplomatic inscriptions dated in the second and third centuries AD and found in the African city of Volubilis containing testimony to the negotiations

\footnotetext{
34 Suet. Tib. 31. 2; Tac. Ann. 3.6o-63.

35 Souris 1984, op. cit. (n. 6), 163-171.

36 Ibidem.

37 Kayser 2003, op. cit. (n. 11), 456-46o.
} 
between the gens of the Baquates and the procurator of the province who, on behalf of the emperor, signed or ratified the peace with a people on the fringes of the empire. ${ }^{38}$ The fact that these inscriptions refer to a series of colloquia, meetings to build a relationship between both peoples, though not strictly in bilateral terms, might support the idea that the provincial governor took on a good deal of the diplomatic work which in principle corresponded to that of the emperor.

The economic impact on different western communities which the dispatch of legationes must have entailed cannot be overlooked. As many of these embassies, especially from the Flavian period onwards, dealt precisely with economic difficulties for those communities this must have also acted as a deterrent. The mention on inscriptions from Africa, Sicily (Malta) and Hispania of individuals who either cover the expenses of a specific legatio or offer to do so in perpetuity to favour the civic community must be highlighted in this context. ${ }^{39}$

\section{Persuasion and Western Embassies}

Beyond mere considerations of quantity, an indication that possibly supports the notion that some differences existed between the type of diplomatic mobility in the east and the west could be how sources deal with the most significant component of any embassy: powers of persuasion. While no differences exist in the motives why legati from cities and provinces would travel to see the princeps, the fact remains that up until the third century AD descriptions of the abilities and rhetorical skills of western embassies are scarce. Whereas Tacitus expounds in detail upon the rhetorical arguments of some of the legates of Greek cities arriving in Rome, little is known about the arguments and techniques of persuasion used by western ambassadors. Information is mostly practical, recording what was requested and the outcome of the negotiation. The deployment of brilliant rhetoric does not seem to have been a priority for them. By contrast, embassies from the east seem to have put more effort in preparing for their encounters with the princeps. This, once more, supports the

$38 \quad$ IAM 2.2.349; 350; 353; 356; 357; 358; 359; 360; 384; 402. J. Kolendo, 'Les inscriptions de Volubilis et les relations diplomatiques entre les romains et la tribu des Baquates', Archaelogia 57 (2006), 45-50. 
notion that within their institutions this was a common practice from which they drew greater benefits. Therefore more importance was attached to it. ${ }^{40}$

As pointed out above, the need for these legationes to succeed was directly linked to their persuasive abilities ${ }^{41}$ which in turn directly depended on the benevolence of the princeps. Quite often, given their honorary nature, embassies were clearly laudatory. A large number of them, in order to take advantage of the long journey and the cost of the embassy, combined the need to please the princeps and to procure advantages for their communities' position within the empire. Frequently enough, these embassies would exchange honours for favours as they needed to attract the emperor's benevolence before putting forward their requests..$^{42}$ This guideline was followed, for instance, by the offering of honorary patronages or duumvirates to the emperor or to members of the imperial family. 43

In this context of praise and commendation it is quite striking that Plutarch, in his political advice, claims that ambassadors needed to show courage when speaking before the emperor:

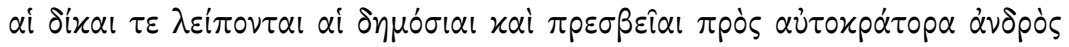

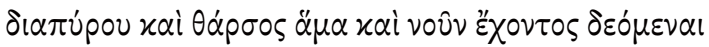

There remain the public lawsuits and embassies to the emperor, which demand a man of ardent temperament and one who possesses both courage and intellect. ${ }^{44}$

In the earlier Republican period, when the need to submit to Roman power by many embassies arriving in Rome was essential, setting forth conditions for an alliance with the Romans or reiterating alliances were the recurrent topics amongst foreign legationes. The attitude of ambassadors requesting favours from Rome was defined by a line drawn between the supplication demanded from enemies and the acknowledgement of Rome's power expected from friends. Similarly, the tasks of Roman embassies sent to those communities clearly fluctuated between posing demands on friends and intimidating enemies, which both required resolve and, above all, courage, on the side of the Roman ambassadors.

\footnotetext{
40 J. Edmonson 2015, op. cit. (n. 4), 701-729.

41 Men. Rh. 423; Rodríguez Neila 2010, op. cit. (n. 10), 264.

42 Kayser 2003, op. cit. (n. 11), 443-444.

43 Rodríguez Neila 2010, op. cit. (n. 10), 229.

44 Plut. Praec. ger. Rei publ. 805A.
} 
Diplomatic rhetoric during the empire was dominated by subordination to the princeps. It was essential to show loyalty to the institution and thus receive the necessary assistance for the development and well-being of the community within Rome's administrative system. In this sense, bringing an embassy to a successful conclusion was, as already mentioned, an essential element of the entire process. Yet, if we consider Tacitus' report on Tiberius' satisfaction upon listening to the "pleasant allusions" —laeta Tiberio-made in his presence by an embassy of Segestans, we must conclude that some of the success of legationes lay in the orators' capacity to persuade and convince the princeps:

et Segestani aedem Veneris montem apud Erycum, uetustate dilapsam, restaurari postulauere, nota memorantes de origine eius et laeta Tiberio.

The Segestans also demanded the restoration of the age-worn temple of Venus on Mount Eryx and told the familiar tale of its foundation; much to the pleasure of Tiberius, who as a relative willingly undertook the task. ${ }^{45}$

Although Tacitus' reference is brief it demonstrates two key points of political discourse: firstly a reference to the origins of the city, and secondly direct allusions to the emperor, which in this case referred to the relations between the gens Iulia and Venus and also with the temple of Eryx. ${ }^{46}$

Embassies may have alluded to the age-old relationship between their city or province and Rome, delving into aspects which would best enhance the loyalty - fides - of the community; in fact, this was an essential element in the discourse of embassies coming from Gallia. All the diplomatic rhetoric of a city such as Massilia, located in the west, though of Greek culture, was precisely based on its relationship of fides towards Rome. ${ }^{47}$ Likewise, allusions to the origins of the city and its relationship with Roman emperors recurred time and again. A concern for origins and a predilection for continuous exaltation appear in the titles of the main cities in Hispania, recalling the circumstances of creation and promotion of the city. ${ }^{48}$ These phenomena could also be linked to 'kinship diplomacy' or diplomacy established on the basis of a common origin of the communities involved. This element may have been used by embassies

\footnotetext{
45 Tac. Ann. $4 \cdot 43$.

46 B. Poulle, 'Religion et récit historique: les ambassades des sanctuaries grecs sous Tibère (Tacite, Annales III, 60-63', Dialogues d'histoire ancienne 4 (2010), 343-35.

47 D. Roman, 'Marseille et la fides de Rome', Revue archéologique de Narbonnaise 23.1 (1990), 213-220.

48 Le Roux 2010, op. cit. (n. 26), 230.
} 
coming from Saguntum, a western city of Greek origin, though this diplomatic practice was uncommon in others diplomatic cultures in the West. ${ }^{49}$

When elements to attest to a relationship of loyalty or proximity were lacking, the appearance of a wonderful feature that could attract the princeps' attention towards a city so far unknown to him could be resorted to. For example, Pliny the Elder reports the embassy from the city of Olisipo in Lusitania to inform the emperor Tiberius of the presence of a Triton on their shore, located precisely on the border of the empire:

Tiberio principi nuntiauit Olisiponiensium legatio ob id missa, uisum auditumque in quodam specu concha canentem Tritonem qua noscitur forma. et Nereidum falsa non est, squamis modo hispido corpore etiam qua humanam effigiem habet. namque haec in eodem spectata litore est, cuius morientis etiam cantum tristem accolae audiuere longe, et Diuo Augusto legatus Galliae conplures in litore apparere exanimes Nereidas scripsit.

An embassy from Lisbon sent for the purpose reported to the Emperor Tiberius that a Triton had been seen and heard playing on a shell in a certain cave, and that he had the well-known shape. The description of the Nereids also is not incorrect (...); for a Nereid has been seen on the same coast (...); also the governor of Gaul wrote to the late lamented Augustus that a large number of dead Nereids were to be seen on the shore. ${ }^{50}$

They were thus trying to boost the relevance of a city which was so far of little or no relevance amongst the territories of the empire.

It is also probable that many of these cities, besides referring to history or mythology also used more realistic persuasive techniques such as referring to population increase or to their capacity to act as solid defensive strongholds. ${ }^{51}$

Nevertheless, it is quite interesting that western embassies do not appear to have excelled in rhetorical matters, ${ }^{52}$ in contrast to Greek ones, whose forms

\footnotetext{
49 Sil. 1.265-294; Torregaray Pagola 2013, op. cit. (n. 18), 330-331; M.T. Schettino, 'Sagunto e lo scoppio della guerra in Silio Italico', Aevum Antiquum 6 (2006), 53-63.

50 Plin. NH. 9. 5 (4).9.

$5^{1}$ I. Savalli-Lestrade, 'Devenir une cité: Poleis nouvelles et aspirations civiques à la basse époque hellenistique', Citoyenneté et participation à la basse époque hellénistique (Genève 2005), 12.

52 Poulle 2010, op. cit. (n. 46), 343-350.
} 
of addressing the emperor are even mentioned alongside the oratory skills of the legati and the originality of their arguments. There are no traces in the west either of what A. Chaniotis refers to as 'affective diplomacy' which significantly enriched the rhetoric of Greek embassies in the Republican period. ${ }^{53}$ Quintilian only quotes the incident of the palm on the altar of Augustus in Tarraco; and mentions the condolences to Nero on the death of his mother from an embassy from Gaul. ${ }^{54}$ In general, the only evidence left from western legationes consists of the successful dealings of the ambassadors and the details of their petition; no reference is made to their particular rhetorical skills. Probably one of the reasons was the fact that on the one hand they tended to use widespread and habitual formulas of praise while on the other hand they used formulaic language matching the petitions they made. This obviously limited rhetorical originality; moreover, Latin writers may not have been inclined to record diplomatic expressions that were considered commonplace.

In this respect, I believe that in order to understand such a context in which the diplomatic act is more significant than the rhetoric used, it is useful to go back to the inscriptions found in Volubilis recording the negotiations between the gens of the Baquates and the governor of the province of Mauritania Tingitana, acting on behalf of the emperor. The texts refer to a series of diplomatic colloquia aimed at signing or ratifying peace agreements. ${ }^{55}$ The repeated reference to the diplomatic act as a colloquium, negotiation, precisely stresses the existence of encounters in which a conversation was staged, that probably comprised of a series of formulas of symbolic rather than rhetorical content. ${ }^{56}$ Nonetheless, the epigraphic mention of the negotiations for peace as a diplomatic act is quite original in this western area of the Roman empire, all the more so if we bear in mind that it entailed the regular mobility of the Baquates to reiterate the ties of alliance linking them to the Romans.

53 A. Chaniotis, 'Affective Diplomacy: Emotional scripts between Greek communities and Roman authorities during the Republic', in D. Cairns and L. Fulkerson, eds., Emotions between Greece and Rome (London 2015), 87-103.

54 Quint. Inst. 6.3.77: Et Augustus, nuntiantibus Terraconensibus palmam in ara eius enatam, "apparet" inquit "quam saepe accendatis", "Again, Augustus remarked, when the citizens of Tarraco reported that a palm tree had grown on his altar, 'Now we know how often you light the fire on it'”; 8.5.15. Ziethen 1994, op. cit. (n. 4), 244-245.

55 N. Brahmi, 'Les colloquia romano-baquates: patronage divine et intégration', in R. Compatangelo-Soussignan and C.G. Schwentzel, eds., Étrangers dans la cité romaine (Rennes 2007), 155-170.

$5^{6} \quad$ e.g. IAM 2.2.350 (conlocutus). 


\section{Conclusions}

It can be concluded that the emperors' need for legitimation and adhesion to themselves, their families and the imperial institution created a reduced though constant flow of ambassadors between western communities and Rome, for mutual benefit. Legationes contributed to the increase of the visibility of these communities before the princeps; that is, those who could afford this type of mobility. And the emperor saw his position of power constantly reinforced as a result of the constant wish of local and provincial embassies to have direct access to him. What is more, the establishment of Rome's administrative system contributed to exposing a series of management issues which prompted the mobilization of local and provincial elites seeking the favour of the princeps in solving the financial problems of their communities.

As a result, a pattern was created of diplomatic mobility from the western periphery towards the centre of power. Scarce as testimonies to this mobility may be, they reveal a continued relationship between western provinces and the highest representative of power in Rome.

San Sebastián, January 2016 


\section{Bones, Stones, and Monica ${ }^{1}$ Isola Sacra Revisited}

Laurens E. Tacoma

For Henk Versnel, who taught me to cherish inconsistencies

Traditionally, studies of migration and mobility have relied to a large extent on the analysis of the thousands of epitaphs that have survived from the Roman world. The epigraphical evidence from the period of the Principate is abundant, but there are also reasons for caution. We are dependent on patterns of commemoration and self-representation. One major problem for the study of Roman migration through epigraphy is that identity was not necessarily expressed in ethnic terms: in many cases legal and social status were more important. Moreover, epitaphs offer static snapshots of what was by definition a dynamic process. In consequence, we have evidence of people who moved,

1 This paper is one of the by-products of a research project on Roman migration and labour conducted at Leiden University; I wish to thank the Netherlands Organisation for Scientific Research (NWO) for funding the Moving Romans project. The section on Augustine was presented in extended form at a seminar in Amsterdam in June 2015; the present paper at the Impact conference in Rome and at a seminar on Migration and mobility at Augsburg in Jan 2016. My thanks to the three audiences for offering helpful suggestions. Some of the discussion on the isotopes is taken from my monograph Moving Romans. Migration to Rome in the Principate (Oxford 2016), where a general discussion of sources for the study of migration can also be found, in chapter 1. Further reflections on the use of the epigraphic sources can be found in L.E. Tacoma and R.A. Tybout, 'Inscribing Syrian mobility in the Hellenistic and Roman period', in: A.J. Yoo and A. Zerbini, eds., A Home Away from Home. New Paths to the Study of Migration and Migrant Identities in the Eastern Mediterranean from the Roman Period to the Crusades (Farnham, forthcoming). 
but hardly ever can see how they moved, let alone what caused them to move. Motivation can hardly ever be inferred from such texts.

The dynamics of migration are in principle better visible in literary sources. Here we can see the itineraries of individuals, and what decisions lay behind movements. At the same time, it is hardly a secret that an analysis of such texts suffers from all the problems traditionally associated with ancient literary sources: they cover the elite only, they may be embedded in moral discourses, and they might privilege the exceptional over the normal.

In recent years, written sources have been supplemented by findings from bio-archaeological studies. In particular the analysis of isotopes in human bones and teeth has been shown to hold great potential. By comparing ratios of stable isotopes in teeth and bones within a sample, it is possible to distinguish between immigrants and locals.

It is obvious that these three types of sources can contribute significantly to our understanding of Roman migration patterns. But the question of how these findings relate to each other has not been addressed fully. That is the aim of the present article.

There is one place in the Roman world for which it is possible to make a direct comparison between the three different source types. This is the Isola Sacra necropolis at Ostia/Portus, the harbour city of Rome. Its skeletons have been subjected to isotopic research. Isola Sacra is also exceptionally well documented epigraphically and archaeologically. Moreover, Ostia figures prominently in what is arguably the fullest migration account to survive from the Roman period, Augustine's Confessiones. As I will argue, the mismatch between the three types of sources is relatively large. They each tell a rather different story. Each of them also has particular problems of interpretation. At the same time, there is no reason to privilege any of the three types, and this raises major methodological problems about the handling of the evidence.

Over the last two decades bio-archaeologists have subjected human skeletons to all types of analysis. The best results thus far have been achieved by the analysis of stable isotopes from teeth and bones. Isotopic analysis is based on the principle that, during the growth of teeth and bones, the food and water that are consumed produce a chemical profile that is geographically specific. By comparing ratios of stable oxygen or strontium (or other) isotopes in teeth and bones within a sample, it is possible to establish the extent of homogeneity 
within such a sample. Individuals with a markedly different chemical profile are assumed to have grown up elsewhere and hence to be immigrants. ${ }^{2}$

Isotopic analysis of skeletal remains has a number of advantages. It helps to identify migrants that remain otherwise invisible in the burial record. ${ }^{3}$ It also quite conveniently uses a definition of migration that is (implicitly) also used among scholars who focus on written sources, and which is also used here: Migration is defined as the movement of persons who change their residence from one place to another on a permanent or semi-permanent basis. That is, it focuses on first-generation migrants, independent of legal or social status. ${ }^{4}$ Thirdly, and lastly, isotopic analysis is capable of producing figures for total numbers of migrants within the population under consideration. In that sense it offers the type of quantitative evidence that is so desperately needed.

While the potential of stable isotope analysis is clear, it would be naive to expect too much of it and it would be a mistake to take it as hard factual evidence that speaks for itself. It does not present to us the reference population against which we can judge in what directions the written sources are biased. Apart from technical problems in the analyses (some incidentally quite formidable), major interpretative issues are raised.

These issues have surfaced in a small debate over the findings from Isola Sacra at Ostia/Portus. In 2007 a research team led by Tracey Prowse published a pioneering isotopic analysis of oxygen-stable isotope ratios of series of teeth in a sample of 61 individuals from Isola Sacra in Ostia. It showed a substantial number of migrants among the population. Among the 61 individuals, she found 20 immigrants (33 per cent). ${ }^{5}$ As there were a substantial number

2 T.L. Prowse, 'Isotopes and mobility in the ancient Roman world', in L. de Ligt and L.E. Tacoma, eds., Migration and Mobility in the Early Roman Empire (Leiden 2016), 205-233 for explanation and a very useful survey of the rapidly expanding literature.

3 This is of real importance, as graves and grave-goods in the Roman world are very often ethnically unspecific. For example in the cemetery of Vagnari in Puglia, studied by T.L. Prowse, J.L. Barta, T.E. von Hunnius, and A.M. Small, 'Stable isotope and mitochondrial DNA evidence for geographic origins on a Roman estate at Vagnari (Italy)', in H. Eckardt, ed., Roman Diasporas. Archaeological Approaches to Mobility and Diversity in the Roman Empire. Journal of Roman Archaeology Supplement 78 (Portsmouth 2010), 176: "Evidence from the burials themselves (burial type, grave goods) does not provide a clear indication of differential burial treatment for foreigners versus locals."

4 Tacoma 2016, op. cit. (n. 1), chapter 2 for further discussion.

5 T.L. Prowse, H.P. Schwarcz, P. Garnsey, M. Knyf, R. Macchiarelli, and L. Bondioli, 'Isotopic evidence for age-related immigration to imperial Rome', American Journal of Physical Anthropology 132 (2007), 510-519. In what follows, I use the modified 'local range' established by K. Killgrove, Migration and Mobility in Imperial Rome (diss. Chapel Hill 2010), 249, which leads to slight adaptations of the original figures of Prowse et al. 
of women and children among them, Prowse and her team argued that the traditional male-based migration model, in which it is assumed that migrants are primarily young adult males, was in need of revision. Instead, people moved as families. ${ }^{6}$

In 2010, however, the study by Prowse was criticised by Christer Bruun on several counts. ${ }^{7}$ Bruun argued that the presence of women and children among the immigrants is open to multiple interpretations. While it is certainly feasible that children moved as part of a family together with their parents, they could also have been brought as slaves or, in the case of women, as brides; they may even have moved independently. Depending on their exact age and economic position they may also be classified as 'sub-adults' rather than as children. There is no need to repeat here all of Bruun's arguments and the further responses to his criticisms, which are partly of a technical nature. We may focus here on four relatively simple points.

Firstly, sample size. Prowse used 61 skeletons, on an estimated total number of 2,00o excavated skeletons (of which c.1,0oo are well-catalogued). It must be clear that the dangers of extrapolating the figures to the total population of Ostia, let alone to the wider world, are great indeed: this is a world of smallnumber statistics. Small changes in values immediately affect outcomes. A figure of 33 per cent of immigrants may be suggestive for general levels of immigration, but surely should not be used as the basis for major claims.

Secondly, the outcome of the technical analysis is not as straightforward as one would think: foreignness turns out to be a matter of degree rather than something absolute. A sample produces a spectrum of isotopic values whose outliers are considered to be immigrants, but this leaves room for a grey zone of ambiguous cases. Again, small changes in what is considered the local range have an immediate impact on the percentages of immigrants.

Thirdly, the method is much better at identifying outsiders within a local population than at establishing their origin. Far too little is known about the geological and hydrological profiles of the Roman world to identify geographical origin with any reasonable degree of certainty. So, Prowse mentioned as

6 Prowse et al. 2007, op. cit. (n. 5), e.g. 510 (abstract): “This study demonstrates that migration was not limited to predominantly single adult males, as suggested by historical sources, but rather a complex phenomenon involving families."

7 C. Bruun, 'Water, oxygen isotopes, and immigration to Ostia-Portus', Journal of Roman Archaeology 23 (2010) 109-132, with response by K. Killgrove, "Response to C. Bruun, "Water, oxygen and immigration to Ostia-Portus", Journal of Roman Archaeology 23 (2010), 133-136. The debate is unresolved; see for a second round C. Bruun, 'Tracing familial mobility: female and child migrants in the Roman West', in L. de Ligt and L.E. Tacoma, eds., Migration and Mobility in the Early Roman Empire (Leiden 2016), 176-204 with reiteration of the major criticisms, and Prowse 2016 op. cit. (n. 2) for a defence. 
possible origins of the immigrants buried in Isola Sacra the area "north of the Italian landmass", "the foothills and heights of the Apennine Mountains" and "the Iberian Peninsula or Greece", among others. ${ }^{8}$

Lastly, the logic of the interpretation of the data on which the claim for child migration is based, is problematic. The analysis used oxygen stable isotopes from first and third molars to determine local and non-local origin. The first molar is formed before birth and completed around age 2.5-3.0; the third starts to form at age 7-12 and is completed at age 10-17.5. In an ingenious argument, Prowse used the time gap between the first and the third molar to determine the moment of migration. People with a non-local first molar and a local third molar can be thought to have migrated before the completion of the third molar, that is, in their youth; people with non-local first and non-local third molars, to have migrated as adults. The analysis of the Isola Sacra data found among 61 individuals 13 child immigrants, and seven adult immigrants (see Table 1, rows 1-3). This produced a remarkable pattern, with almost twice as many children as adult immigrants, and this in turn led to the argument about the importance of family migration.

However, what on closer inspection also emerges from the data, is that there is an additional group whose migrant history is less easy to explain: those with a local first molar and non-local third molar (see Table 1, row 4). This group consists of eight persons. According to the logic of the argument, they must have been born in Ostia, moved elsewhere in their teens (before the formation of the third molar started, at age 12 at the latest, but possibly as early as age 7), and then after their third molar was completed they returned to Ostia, where they subsequently died. Although it is certainly possible to come up with scenarios, it is very difficult to think of a coherent pattern that can explain such movements. It is disconcerting that this group was ignored in the original publication of the research, particularly in view of the claims about the importance of child migration. In fact, and somewhat strangely, this group of young 'remigrants' was silently subsumed under the local population. The point would be of minor academic interest, were it not for the fact that the whole claim of child migration rests precisely on these third molar data. Part of these data were thus used to make the claim for child migration, but part of it was ignored for the group that was less easy to interpret, the 'remigrants'. That seems inadmissible. If the third molar data are left out of consideration, much of the case for child migration is lost: we are left with 20 immigrants who came to Ostia at an unknown point in time after their first molar had formed.

8 Prowse et al. 2007, op. cit. (n. 5), 517-518. 
TABLE $8.1 \quad$ Isola Sacra data (source: Prowse et al. 2007, op. cit. (n. 5), with Killgrove 2010, op. cit. (n. 5), 249)

\begin{tabular}{llll}
\hline Mi & M3 & N & Interpretation \\
\hline Local & Local & 33 & locals \\
Non-local & Local & 13 & child immigrants \\
Non-local & Non-local & 7 & adult immigrants \\
Local & Non-local & 8 & 'remigrants'? \\
\hline
\end{tabular}

Prowse's study certainly deserves credit for its pioneering efforts. However, it should also be clear that given the present state of the evidence, large claims cannot be based on the isotopic analysis alone. The evidence is certainly not as hard as ancient historians might take it to be. If Prowse's claim for family migration is rejected, one is easily left with the impression that the isotopic study has merely reinstated something that could have been assumed on a priori grounds - a high level of immigration is a natural characteristic of harbour cities-and whose particulars are better documented by the abundant epigraphic evidence that survives from Ostia.

\section{$3 \quad$ Stones}

In the debate on the work of Prowse, it has not been fully taken into account that the Isola Sacra necropolis is itself exceptionally well documented epigraphically and archaeologically. ${ }^{9}$ It is therefore possible to compare in a much more direct fashion the findings from isotopic studies with those from epitaphs and literary texts. ${ }^{10}$ The inscriptions and tombs allow for the creation of

$9 \quad$ The possibility was mentioned by Bruun 2010, op. cit. (n. 7), but it seems no coincidence that the epigraphic examples that he cites himself come from other areas of Ostia. It is discussed briefly by Prowse 2016 op. cit. (n. 2), 216-217: she and her team refrained from analysis partly on the grounds that "the epigraphic record only records the origins of individuals in a small number of cases." That is exactly the point.

10 Though not in the most direct way. As the exact provenance of the skeletons is undocumented, it is not possible to connect particular tombs and inscriptions with particular skeletons. See Prowse 2016 op. cit. (n. 2), 217 for some remarks: after the excavations were completed, skeletons were apparently dumped back in the graves, but not necessarily their own. 
a social profile of the population that was buried at Isola Sacra, and permit an analysis of how mobility was inscribed.

In what follows, I confine myself for practical reasons to the area of the so-called 100 tombs, excavated mainly in $1930 .^{11}$ The area presents a coherent corpus. It forms one of the best examples of an ancient Grabestrasse with wellpreserved tombs and many inscriptions and reliefs still in situ. The tombs are well described, and the inscriptions have been edited twice. ${ }^{12}$ In total there are 114 Latin and 6 Greek inscriptions. ${ }^{13}$

Although the inscriptions have no internal dates, and some ambiguous cases remain, the chronology is relatively clear. Most tombs have been well dated on stylistic grounds, on the basis of brick stamps or on the basis of onomastic criteria in the inscriptions. The majority of tombs stem from the middle of the second to the early third century and thus present a relatively small slice of the imperial period. ${ }^{14}$ The chronology is of importance, for the 100-tomb graveyard is one of the best witnesses to the shift from cremation to inhumation that took place in this period. Some tombs contain solely cremation burials, others solely inhumation graves, and some a mixture of both; in addition, the inscriptions occasionally refer to either or both burial practices. ${ }^{15}$ The shift

11 This includes some additional finds from the same area made subsequently. Note that the territory comprised by Isola Sacra is much larger than the 100-tomb area alone, though excavations have mostly taken place in its vicinity. There are also tombs and inscriptions found outside the 100-tomb area, or inscriptions that could not be related to a particular tomb, both in earlier and in subsequent excavations. Although some of these concern larger family tombs, the general picture that emerges from these other tombs seems very similar to what can be gathered from the 100-tomb area.

12 Inscriptions: H. Thylander, Inscriptions du port d'Ostie (Lund 1952) (IPOstie); A. Helttula et al., Le iscrizioni sepolcrali latine nell'Isola sacra (Rome 2007) (ISIS). The new edition offers a more complete series of texts (despite the titleincluding also the Greek ones), and improved readings and dating, and also has a very full series of extremely useful indices. However, the later edition does not completely replace the earlier one as Thylander offered some historical commentary and provided translations. The tombs themselves are described in the ISIS publication, but full photographic documentation can be found at http:// www.ostia-antica.org/valkvisuals/html/tombsintro.htm (last consulted February 2016).

13 Latin: ISIS 21 = IPOstie A13 (tomb 1) - ISIS 133 = IPOstie A122 (tomb 10o); Greek: ISIS $15^{\text {gr }}$ (tomb 6a) - ISIS $20^{\text {gr }}$ (tomb 65).

14 There is one early fourth-century Christian grave: ISIS $42=$ IPOstie A285 (tomb 38), but this concerns the reuse of an older tomb. At the other end of the chronological spectrum, ISIS 50 = IPOstie A6o (tomb 49) may perhaps date to the second half of the first century, but a Trajanic date is also possible.

15 For cineres, see ISIS 53 = IPOstie A75 (tomb 51); for ollae, see ISIS 124 = IPOstie A124 (tomb 94); for sarcophagi, see e.g. ISIS 29 = IPOstie A9o (tomb 16), with many more examples 
to inhumation incidentally strongly suggests that the skeletons analysed by Prowse date from the early third century rather than the general period of the first to third centuries AD.

Obviously, tombs and their inscriptions served primarily to commemorate the dead. In doing so, the emphasis was on communication between the dead and the living, between commemorated and commemorator. ${ }^{16}$ But, as is well known, communication was also directed at third parties, at the outside world of fellow citizens of Ostia and Portus. The people who built the monuments and erected the inscriptions were not plainly documenting who they were, but were portraying who they wanted to be, and in that sense the tombs are not a mere mirror of urban society. The people who made them engaged actively in self-representation. ${ }^{17}$

The social profile of the people buried in the tombs covers a significant part of the urban population. There are no persons who belonged to the urban elite proper (no decurions, no magistrates, no high-ranking administrators), but the sub-elite strata seem well represented. In one case an occupation is mentioned, that of a tabellarius. There are some occupational reliefs depicting among others a baker, a midwife, and a surgeon, and there are also some hints at trading activities. ${ }^{18}$

The focus in the inscriptions is very much on the family. Just as elsewhere in the Roman world, the families that are buried in the tombs are predominantly nuclear: they consist of a husband, wife, and children. The family is small, and covers a limited number of generations. Only rarely do we find tombs with three or more generations. ${ }^{19}$

given in the ISIS-index, Helttula et al., op. cit. (n. 12), 397, and the remarkable prohibition of ISIS 106-107: ita ne in hoc monumento sarcophagum inferatur. ISIS $27=$ IPOstie A245 (tomb 11) mentions corpus sibe ossa. ISIS $141=$ IPOstie A256 (tomb 102) mentions ollae and sarcophagi.

16 V.M. Hope, Roman Death. The Dying and the Dead in Ancient Rome (London and New York 2009), esp. 151-181.

17 Obviously, in some cases the claims concerned the deceased relatives rather than the persons who commemorated them, so the term 'self-representation' is not always strictly appropriate. But note that many of the tombs were built inter vivos.

ISIS 127 = IPOstie A279 (tomb 96), for a tabellarius, an imperial freedman. For reliefs, see e.g. tomb 78 (sailor and baker), tomb 90 (a sailer and ostiaria), tomb 100 (a midwife and surgeon).

19 Tomb 4a contains different persons belonging to the same family. Tomb $75^{-76}$ is a very large tomb with a complex structure involving three families; it was eventually split into two separate tombs. 
The family is small, but the familia is not. One of the most striking aspects of the Isola Sacra tombs is the prevalence of slavery and the multiplicity of forms in which slavery was inscribed. Many of the cremation tombs contain a remarkable number of niches set into the walls. Given the small size of the families buried in such tombs, and the fact that most tombs seem to have held only the remains of a very limited number of generations, the implication is that at sub-elite levels the extent of slavery was large-perhaps larger than is normally assumed..$^{20}$ The conventional phrase that the tomb also provides for the burial of 'freedmen, freedwomen, and their descendants' suggests that former slaves remained close to their owner. Slaves also appear in other capacities. There are a significant number of commemorations of deceased slaves by their owners, but also by fathers or mothers with single names and thus presumably slaves who commemorated their deceased slave children. In addition, slaves and liberti set up monuments for their owners and former owners, and there are even some liberti who set up monuments for themselves while including their owners, in a nice reversal of patronage relations. There are also a significant number of imperial slaves and freedmen. ${ }^{21}$

Most of the persons mentioned by name in the inscriptions sport a tria nomina (or duo nomina in the case of women), indicating Roman citizenship. As filiation is often lacking, it remains uncertain whether we are dealing with freedmen or freeborn. ${ }^{22}$ In a number of cases the cognomina are suggestive of slave descent, and there are some cases where the fact that husband and wife share the same gentilicium reveals their former slave status. ${ }^{23}$ There are also

20 As tombs may have been split between different owners, the number of niches cannot be used as a direct indicator for sizes of slave familiae. The figures mentioned in some inscriptions are probably more indicative. See ISIS 116 = IPOstie A47 (tomb 9o) for 9 sarcophagi for husband and wife and their freedmen and descendants; ISIS 124 = IPOstie A124 (tomb 94) for a man buying part of a tomb, comprising 14 ollae; ISIS 29 = IPOstie A9o (tomb 16) for 12 sarcophagi. For archaeological data on numbers of inhumation graves, see B. Borg, Crisis and Ambition: Tombs and Burial Customs in Third-Century CE Rome (Oxford 2013), 22-23; note that one of the largest ones could house 150 sarcophagi (tomb 34). ISIS 50 = IPOstie A6o (tomb 49); ISIS 87 = IPOstie A261 (tomb 75); ISIS 117 = IPOstie A104 (tomb 90); ISIS 119 = IPOstie A77 (tomb 91); ISIS 123 = IPOstie A96 (tomb 94); ISIS 125, ISIS 127 = IPOstie A279 (tomb 96).

For a (rare) counter example with filiation and tribus, see ISIS 32-33 = IPOstie A249-A250 (tomb 19).

23 E.g. ISIS $120=$ IPOstie A121 (tomb 92) for a family of freedmen; the dedicator acting together with a freedman of his own. Conversely, the most likely explanation of the fact that in ISIS $128=$ IPOstie A146 and ISIS $129=$ IPOstie A147 (tomb 97) the mother and two sons each have different gentilicia is that they were former slaves of different owners. 
some inscriptions where the references to col- or conliberti explicates status. ${ }^{24}$ It thus seems not far-fetched to suppose that a significant proportion of the Roman citizens of the 100-tomb area had acquired their citizenship through manumission.

Although the tombs belong to the sub-elite population, a significant number of them clearly give a sense of affluence. The simple fact that plots are bought, sold, ${ }^{25}$ and partitioned ${ }^{26}$ suggests a lively market in burial plots, implying at least a modicum of wealth. More direct evidence for wealth is provided by tomb size (both physical tomb size and the sizes that are mentioned in inscriptions): some of the tombs were remarkably large. ${ }^{27}$

The graves not only convey a sense of affluence, but on closer inspection also show significant variation in wealth. The variation in size is marked, and certainly not all tombs are chamber tombs. Some graves are in fact rather poor. A couple of them are built at the back (and out of sight) of the larger tombs. At the lower end of the social scale, there are also graves consisting of little more than a simple grave marker like an amphora, slotted into the available space. ${ }^{28}$

The social profile of the people buried at Isola Sacra is perhaps not particularly surprising, and fits well with the general picture of urban society of Roman Italy. It is rather the completeness with which it is documented that is remarkable. This makes it all the more striking that migration and mobility are not very well inscribed. Among the 120 inscriptions there is exactly one explicit reference to a migrant: ${ }^{29}$

$\mathrm{D}$ (is) $\mathrm{M}$ (anibus) / C(ai) Annaei Attici Pict(onis) / ex Aquitanica pro(vincia), def(uncti) / ann(orum) XXXVII, domestici / eius ponendum curarunt

24 ISIS 26 = IPOstie A244 (tomb 11); ISIS 79 = IPOstie A238 (tomb 71); cf. ISIS 78 = IPOstie A239 (tomb 70).

25 E.g. in ISIS 93=IPOstie A17 (tomb 75); ISIS 94 (tomb 75); ISIS $113=$ IPOstie A180 (tomb 89).

26 ISIS 51 = IPOstie A64 (tomb 50) mentioning ex portionibus; ISIS 92.

27 The measurements written in inscriptions range from $10 \times 10($ ISIS 37,55$)$ to $40 \times 40$ Roman feet (ISIS 82), see ISIS index, Helttula et al., op. cit. (n. 12), 391-392; this seems in line with the range of the physical remains. Not only is plot size important, but also tomb height, as many tombs contained a second floor. Tombs could be shared between different owners, but that generally seems to be a subsequent development.

28 Hope 2009, op. cit. (n. 16), 158.

29 ISIS 21 = IPOstie A.13 (tomb 1); with L. Wierschowski, Fremde in Gallien- 'Gallier' in der Fremde. Die epigraphisch bezeugte Mobilität in, von und nach Gallien vom 1. bis 3. Jh. n.Chr. (Texte-Übersetzungen-Kommentare). Historia Einzelschriften 159 (Stuttgart 2001), 15, nr. 3. A second case of an ethnicon may be hidden in the end of the name of Lucius Malius Natalis $C_{+}[---]$in ISIS $34=$ IPOstie $\mathrm{Al}_{11}$ (tomb 50), but its reading is extremely uncertain. 
To the gods of the underworld of C. Annaeus Atticus, Pictone from the province Aquitania, who died when he was 37. His servants have taken care [that this monument] was erected.

The epitaph mentions a freeborn or freed Roman citizen named Caius Annaeus Atticus, who died in his thirties. He was described as belonging to the Pictones, a people in Aquitania, and to come from the province of that name. He was commemorated by his domestici, presumably his servants. The fact that he was buried in Ostia may suggest that he migrated as a trader; the fact that he was buried there and had servants to bury him may suggest he had settled there. All this is of course rather speculative, and the fact that no named commemorators are mentioned and that he appears as an adult male without family, may just as well imply that he died en route.

Perhaps the most interesting aspect of this migrant is not the text of his inscription, but the form of his tomb. It is relatively small, and it has a peculiar shape: a pyramid. It has repeatedly been emphasized over the past decades that Aegyptiaca have little to do with the presence of Egyptians. ${ }^{30}$ There are some more tombs with pyramid shapes, but the fact that this one was made for a migrant from Gaul is an explicit demonstration of that fact.

There are, to be sure, more hints that point towards mobility apart from this one inscription that explicitly mentions migration. However, they are suggestive rather than that they really prove that mobility took place. ${ }^{31}$

The first and most obvious of these hints is the wide prevalence of slaves. In itself slavery need not imply immigration, as many slaves may have been born in Ostia. As Scheidel has argued on general grounds, the large slave populations that we find in the Roman Principate can only have been sustained by a significant amount of self-reproduction. ${ }^{32}$ Many of the slaves of Ostia are thus likely to have been vernae. On the other hand, the openness of Ostia as a harbour city makes it hard to believe that at least some slaves did not come from elsewhere.

$30 \quad$ See M.E.J.J. van Aerde, Egypt and the Augustan Cultural Revolution. An Interpretative Archaeological Overview (diss. Leiden 2015).

31 In addition to the cases discussed below, there are with different degrees of probability also some cases of peregrines: ISIS 60 (tomb 55a) dedicated Alypo Ionici f(ilio); possibly also ISIS $20^{\mathrm{gr}}$ (tomb 65); ISIS 81 = IPOstie A218 (tomb 74), though these could also concern slaves. Note that such peregrines need not be first-generation migrants.

32 W. Scheidel, 'Quantifying the sources of slaves in the Early Roman Empire', Journal of Roman Studies 87 (1997), 156-169, with some further comments in Tacoma 2016 op. cit. (n. 1), chapter 2. 
A second hint for migration and mobility is provided by language use. Some inscriptions are written in a Latin that seems less than perfect, suggesting the dedicator had a different first language. ${ }^{33}$ In addition, there are six Greek texts. ${ }^{34}$ Some of these are certainly suggestive of outsider origin. Most of the Greek inscriptions show Latin influence (for example in the use of formulae) and the tombs in which the Greek inscriptions appear often also included Latin inscriptions, pointing to more indirect forms of linguistic interaction. ${ }^{35}$ These patterns conform closely to those analysed by Adams in his study on bilingualism in the Roman world. Yet Adams also shows how complex language choices could be, and his central point is that language use is primarily an expression of identity and a sense of belonging rather than a direct pointer to origin. ${ }^{36}$

Lastly, there is some evidence from onomastics. Some cognomina carry strong hints of outsider origin. For example, there is a Malchion, a Semitic name often found among slaves. ${ }^{37}$ But that also immediately points to a problem. Most of such names belong to slaves or freedmen, and decades of scholarship have made clear how complex naming patterns are in their case.

It is not my aim to argue these hints away. In fact, it is surely possible to use a maximising rather than a minimising approach in trying to detect migrants. However, if the strict criteria are employed that epigraphers normally-and with good reason-employ in the study of migration, ${ }^{38}$ the evidence for migration at Isola Sacra is rather meagre. It is confined to exactly one case among 120 inscriptions. Perhaps this is not particularly surprising if we take epitaphs as expressions of belonging. The dynamics were social rather than geographical: people claimed a place in the urban fabric. However, the contrast with the

33 E.g. ISIS $29=$ IPOstie A9o (tomb 16).

34 ISIS $15^{\mathrm{gr}}-20^{\mathrm{gr}}$.

35 Thus, tomb 43 contains not only the Greek ISIS 18gr (with harbour mosaic), but also the Latin ISIS 48 = IPOstie A314, which refers to two persons with the gentilicium Ostiensis, probably former public slaves of Ostia. Borg 2013, op. cit. (n. 20), 22-23 suggests the tomb may perhaps have belonged to "an association of people involved in the public administration of the ports"; this is certainly possible, but it seems just one out of many possibilities.

36 J.N. Adams, Bilingualism and the Latin Language (Cambridge 2003).

37 ISIS 49 = IPOstie A212, for a woman with duo nomina. Further e.g. Vetronia P(ubli) lib(erta) Naphame in ISIS $99=$ IPOstie A276 (tomb 82); Naphame is a Punic name, attested in Rome in $C I L$ 6. 22867 .

38 For a balanced discussion of criteria, see e.g. L. Wierschowski, Die regionale Mobilität in Gallien nach den Inschriften des 1. bis 3. Jahrhunderts n. Chr. Quantitative Studien zur sozial- und wirtschaftsgeschichte der westlichen Provinzen des römischen Reiches. Historia Einzelschriften 91 (Stuttgart 1995), 24-29. 
picture sketched by Prowse is marked. Whatever may be thought of isotopic research, the idea that epigraphy somehow documents mobility and migration better seems difficult to maintain.

4 Monica

The dynamics of migration are in principle better visible in literary sources. One text merits much fuller analysis than it has received thus far: Augustine's Confessiones. ${ }^{39}$ It presents what is arguably the fullest migration account to survive from the Roman period. Although the text is late, it presents a possible model that may be of help in understanding Roman patterns of migration in general. It is, in fact, in many respects unique. It presents in the form of a first-person narrative details of Augustine's movements and that of his mother Monica during the period when he pursued a worldly career. Because Augustine painstakingly if not obsessively reflects on his past life, ${ }^{40}$ we also learn much about the social context of his movements.

39 The possibilities that the Confessiones offer for the understanding of Roman mobility studies have not gone completely unnoticed. D. Noy, Foreigners at Rome. Citizens and Strangers (London 2000), 85-87 mentioned Augustine's case as the only case in the whole of ancient history where migrant motives are discussed in any detail, though C. Holleran, 'Migration and the urban economy of Rome', in C. Holleran and A. Pudsey, eds., Demography and the Graeco-Roman World (Cambridge 2011), 155-180, at 161 n. 35 later poured cold water over the importance of Augustine's remarks by pointing to the highly individualized nature of such motives. B.D. Shaw, 'Challenging Braudel: a new vision of the Mediterranean', Journal of Roman Archaeology 14 (2001), 424 in a discussion of Horden and Purcell's The Corrupting Sea contrasted Augustine's movements to those of peasants who would never leave their own territory. A. Zerbini, 'Human mobility in the Roman Near East: patterns and motives', in L. de Ligt and L.E. Tacoma, eds., Migration and Mobility in the Early Roman Empire (Leiden 2016), 326 n. 73 used Monica's case as an example of the difficulties in determining the nature of migration from the burial record alone. R.A. Tybout, 'Dead men walking: the repatriation of mortal remains', in L. de Ligt and L.E. Tacoma, eds., Migration and Mobility in the Early Roman Empire (Leiden 2016), 390-437 at 411-412 has contrasted Monica's wish not to be buried at home to the normal practice to transport the remains of people who died elsewhere back home. All these observations are useful, but they are little more than stray remarks, often confined to footnotes. See also the paper of Carucci in this volume.

40 P. Brown, Augustine of Hippo. A Biography (Berkeley and Los Angeles 1967), 156: Augustine "is obsessed by the need to understand what had really happened to him in the distant past." 
Although it is tempting to take the evidence for Augustine's migration patterns simply at face value, the Confessiones should be understood in its own literary context. It is in many respects an idiosyncratic work. Notwithstanding Ciceronean and Virgilean echoes, it operates at least partly outside classical literary conventions. Paradoxical though it may sound, it can be regarded both as the first real autobiography in world history and as a work that does not conform to the requirements of the genre. ${ }^{41} \mathrm{It}$ is highly selective in what it presents and what it does not. ${ }^{42}$

The fact that Augustine presents his life story in the light of his subsequent conversion has consequences for the way migration is portrayed in the Confessiones. Mental restlessness, social ambition and sexual longing (an aspect not always discussed but figuring prominently $)^{43}$ are linked to moving around. Aimless wandering (intellectually and spatially) is contrasted with the serenity obtained with conversion to the true religion and deep knowledge of the omnipresence of God. It is no coincidence that after his conversion Augustine returns to Africa and settles down. In the remainder of the narrative of the Confessiones, outer journeys in the real world are substituted by philosophical and religious introspection. He has found rest in God, and has finally arrived home.

There is some reality to the contrast between worldly movements and Christian sedentary life that structures the Confessiones: after his conversion Augustine would not leave North Africa any more and spent most of the rest of his life as bishop of Hippo. He repeatedly expressed reluctance to leave his circle of friends and dependents. ${ }^{44}$ But to describe Augustine's newly found Christian world as sedentary would be seriously misleading. In fact, we know

41 Brown 1967, op. cit. (n. 40), 158-181, emphasizing at 160 "the astounding novelty of the book", and stating at 28 that "no book undermines with such great artistry the assumptions of conventional biography."

42 At a concrete level, this feature is best known from the imbalances in the space devoted to the members of his direct family: his father Patricius receives passing references, his mother Monica plays a central role, while the existence of at least one brother and perhaps two sisters is not mentioned at all and has to be inferred from other works-see Brown 1967, op. cit. (n. 40), 29. For his concubine and their son, see below.

43 Conversion for Augustine implied sexual asceticism; note that in his conversion narrative this was the final and in many ways most difficult hurdle to be taken. See P. Brown, The Body and Society. Men, Women and Sexual Renunciation in Early Christianity (New York 1988), 387-395 for the context.

44 Ep. 10.1-2 (to Nebridius, AD 389). Later in life, he would also point to his advanced age as an impediment to travel. See O. Perler, 'Les voyages de S. Augustin', Recherches augustiniennes 1 (1958) 5-7, on Ep. 269 (to Nobilius, AD 429-430). 
that Augustine as bishop of Hippo travelled quite a bit, both in his see and further away, in particular to attend a large number of church councils at Carthage. Although with one exception, a trip to Caesarea in Mauretania, ${ }^{45}$ the distances covered by these voyages were more limited than previously, the number of such trips was much larger than before his conversion. ${ }^{46}$ It is also important to realise that when Augustine, around the age of 43 in c.397 AD, wrote the Confessiones and entered the dark recesses of his innermost thoughts, he was at the same time extremely busy as bishop and community leader, receiving dozens of guests when he was not himself away. ${ }^{47} \mathrm{It}$ is an aspect of his life that is passed over in silence in the Confessiones.

Notwithstanding its highly artificial character, the contrast between worldly movement and Christian serenity that structures the Confessiones is of great help for the present purposes. It is precisely because Augustine equated his previous wanderings in the world with his mental restlessness that he described them in relatively great detail. There are several elements in Augustine's and Monica's migration history that are worthy of note, some of them not documented elsewhere. ${ }^{48}$

We may begin with the bare facts of Augustine's movements. Although there are the usual quibbles over chronological details, the outline is not in doubt. ${ }^{49}$ Augustine was born in the small town of Thagaste in AD 354. At some stage during his youth, around $365^{-366}$, when he was about 12 years old, he left his parental home and moved from Thagaste to neighbouring Madauros for

45 See Perler 1958, op. cit. (n. 44), 17 and 25, dating the trip to Sept. AD 418. The distance from Carthage would be over a 1,00o kilometres.

46 Perler 1958, op. cit. (n. 44) 10-20 for a very long list; see also S. Guédon, Voyager dans l'Afrique romaine (Paris 2010) annexe 21, aptly observing "[i]l n'y a pratiquement pas une année (...) sans qu'Augustin ne parte sur les routes africaines une partie des douze mois" (43).

47 Brown 1967, op. cit. (n. 40), 200.

48 My enquiry is directed at those elements that are of importance for migration; the practicalities of travel which were a major interest of Perler 1958, op. cit. (n. 44) and to some extent also of Guédon 2010, op. cit. (n. 46) are left out of consideration (the Confessiones is remarkably poor on these anyway). I base myself exclusively on the Confessiones, leaving other works by Augustine (notably the Contra Academicos and the later letters), by his biographer Posidius and works of others out of consideration. And I confine myself to the secular part of Augustine's whereabouts, up to and including his return to North Africa from Italy.

49 What follows is based on O. Perler and J.-L. Maier, Les voyages de saint Augustin (Paris 1969). 
educational purposes. ${ }^{50}$ After a year or two, he moved back to Thagaste, where he spent what we would call a gap year which allowed his father to save money for further study in Carthage. ${ }^{51}$ By the end of autumn in 370 he went to Carthage, and would spend some five years there. ${ }^{52}$ During this period, in or around 371, his father died. After Augustine's stay in Carthage, he went back to Thagaste in 375 to teach for a short period (a year or so). ${ }^{53}$ In 376 he took up a paid position as a teacher in Carthage, where he worked for some six to seven years. ${ }^{54}$ From Carthage he moved to Rome, where he set up his own school. ${ }^{55} \mathrm{He}$ had left his mother Monica behind, but she followed shortly afterwards. ${ }^{56}$ He then successfully applied to become rhetor in Milan, where the emperor resided. ${ }^{57}$ Again, his mother soon followed him. In Milan he converted to Christianity, which led him to renounce his position and terminate an engagement with a young girl from the local Milanese aristocracy. For a brief period, he and his mother moved to nearby Cassiciacum, then they moved back to Milan for his baptism, ${ }^{58}$ and after this they started on the journey homewards. ${ }^{59}$ On the way back home, at Ostia, Monica died, and was buried there. ${ }^{60}$ Augustine stayed for a brief period in Rome and then went back home to Thagaste via Carthage. Shortly afterwards he went to Hippo, as a priest, later to become bishop, where he would hold the see for the rest of his long life.

One of the most noteworthy aspects of Augustine's mobility is its step-wise character. Augustine reached Milan from his home-town Thagaste in several stages. Most of these stages entailed stays of several years. During the African part of his itinerary he also occasionally returned back home, so his movements were not completely linear either. It is noticeable that at no point in time does his change of domicile appear to be intended as permanent. That is to say, that his stays could become permanent always remained a possibility, but it was never a certainty. To be sure, it seems likely that if Augustine had not converted to Christianity he would have stayed in Milan; he had reached the pinnacle of his career and was preparing for marriage with a local girl. But what

$50 \quad$ Aug. Conf. 2.3.5. Maudauros was c. $20 \mathrm{~km}$ away from Thagaste.

51 Aug. Conf. 2.3.5, the return home is to be dated before 13-11-369.

$5^{2}$ Aug. Conf. 3.1.1, cf. 2.3.5. Carthage was almost $250 \mathrm{~km}$ away from Thagaste.

53 Aug. Conf. 4.4.7.

54 Aug. Conf. 4.7.12.

55 Aug. Conf. 5.8.14; 5.12.22.

56 Aug. Conf. 6.1.1.

57 Aug. Conf. 5.13.23, cf. 5.12.22.

58 Aug. Conf. 9.3.5-9.6.14.

59 Aug. Conf. 9.8.17; 9.10.23.

6o Aug. Conf. 9.11.28. 
would he have done had he not obtained his appointment in Milan? Would he have stayed in Rome, despite his negative appreciation of the students there?

The greatest importance of Augustine's mobility is for the idea that migration in the Roman world was dominated by young adult males. The Confessiones both does and does not support the model of migration by young adult males. It does uphold the model in the sense that it is clear that at each step it was Augustine who moved. Initially, when Augustine was a student, his moves were embedded in family considerations. The role of the father (and mother) in the decisions about schooling is clear; Patricius is clearly the one who formulates the ambitions for his son. ${ }^{61}$ Later in his life, when Augustine became a teacher, his family recedes into the background; Patricius is dead, and his mother Monica is following Augustine rather than making decisions for him (though she does not spare him her opinions). It is also noticeable that the individual decision-making by Augustine is embedded in discussions with friends.

The narrative is also interesting because it demonstrates how marriage can function as the point of settling down, both literally and figuratively. It also shows the importance of return migration. In fact, the story of the renunciation of his marriage with a young Milanese girl demonstrates nicely two major options of young male migrants in a new city: marry and settle, or return home. Augustine first considered the former, and after his conversion decided on the latter.

We thus clearly have to do with a young adult male migrant. But Augustine was not alone when he moved through the Roman world.

In the first place, his mother Monica followed Augustine closely. When he went from Carthage to Rome he left Monica behind, in a famous scene full of Vergilian echoes. ${ }^{62}$ But the narrative implies that Monica had previously moved from Thagaste to Carthage. It seems likely that the cause was the death of her husband. After Augustine moved to Rome, his mother followed suit. When Augustine moved to Milan, she again followed him somewhat later. Monica's case probably exemplifies what happened more often in the case when women became widows: they moved in with their children (and most likely with their sons). Yet Monica's case is also interesting because she did travel on her own, and seems to have made her own decisions. In fact, the dramatic scene at Carthage when Monica was left behind-reminiscent of the way that Aeneas left Dido-is presented as a conflict of opinions; Monica as a widow retained her independence.

\footnotetext{
61 Aug. Conf. 2.3.5.

62 Aug. Conf. 5.8.15; cf. 6.1.1.
} 
When Augustine moved around, he did so as an unmarried male. In that sense there was no family migration. However, he did have a concubine. This concubine has acquired some fame as the anonymous attachment to Augustine that figures surprisingly little in the Confessiones. ${ }^{63}$ She appears mainly when he recounts how she had to leave and returned to her native Carthage when his marriage plans were announced in Milan:

avulsa a latere meo tamquam impedimento coniugii cum qua cubare solitus eram, cor, ubi adhaerebat, concisum et vulneratum mihi erat et trahebat sanguinem. et illa in Africam redierat, vovens tibi alium se virum nescituram, relicto apud me naturali ex illa filio meo.

That woman with whom I used to share my bed was torn from my side, on the grounds that she stood in the way of my marriage. My heart, which was so attached to her, was broken and pierced, leaving a trail of blood. She returned to Africa vowing to you that she would never have another man. She left behind with me my son she had borne to me. ${ }^{64}$

The fact that she vowed to continue her life as an univira is very interesting, as in doing so she appropriated concepts normally associated with widowed women in full Roman marriage. But even more remarkable is that from some other casual remarks we learn that Augustine had lived with her for at least a decade. ${ }^{65}$ They also had a son, Adeodatus, who also appears only a few times in the book. ${ }^{66}$ The implication must be that Augustine had moved together with this small family from his stay in Carthage onwards, a family which remains otherwise completely invisible. This family was too unimportant (equal to slaves, one would say), or too embarrassing, to be mentioned. ${ }^{67}$

In modern discussions of Augustine's concubine, it is emphasized that despite Augustine's disparaging remarks, there was for young adult males nothing abnormal about having such a companion. ${ }^{68}$ Although it would be

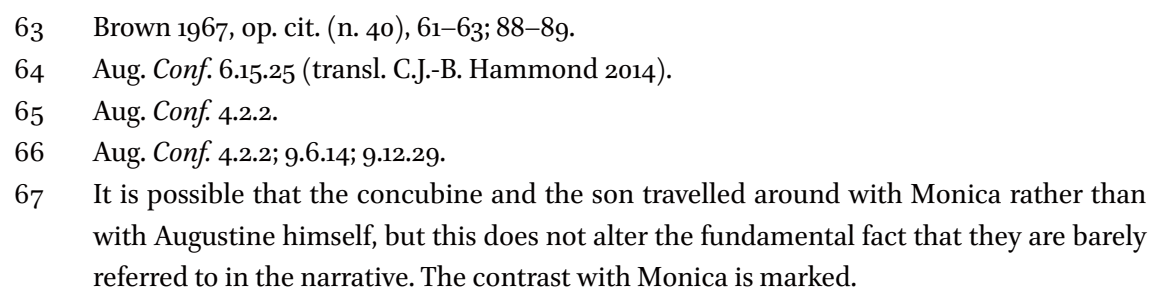

68 Note that her repudiation had nothing to do with Augustine's conversion to Christianity; in fact, as the passage implies, the concubine was already a Christian herself. For the normality of the practice, see B.D. Shaw, "The family in Late Antiquity: the experience of 
rash indeed to assume that all young men who appear as sole travellers in our epigraphic sources did so, the corollary of the argument that concubines were a regular feature in the Roman world might imply that more migrants travelled around with otherwise invisible companions. ${ }^{69}$

The last element meriting discussion is the way death structures what we know about migration, and this brings us back to Monica. The fact Monica died in Ostia was coincidental in the sense that neither she nor Augustine had any desire to stay for longer in Ostia. Monica had lived for prolonged periods in Thagaste, in Carthage, in Rome, in Milan and also for a short time in Cassiciacum, but she was buried in none of these places. Without the Confessiones we would not have any idea why and how this female migrant from Thagaste ended up in Ostia. In fact, we would not even have known that she was a migrant; Monica's epitaph, a commemorative epigram written long after her death, does not refer to her mobility at all. ${ }^{70}$ Moreover, Monica had initially made arrangements to be buried in Thagaste in the tomb of her husband Patricius, but only on her deathbed changed her mind. ${ }^{71}$ Her story is of real interest, as it makes clear that the norm was to be buried in home grounds, and that the ashes or bones had to be transported back if people died elsewhere. In this case, as Augustine was accompanying her, that could have been easily arranged. Monica decided otherwise, and opted for burial at Ostia. If she had been interred alongside her husband in Thagaste, who would have known from her grave that she had seen quite a bit of the world at all?

A fundamental and obvious problem remains: how representative are the Confessiones? Obviously, Augustine and Monica are not representative of every migrant who moved in the Roman empire. We are dealing with members of the elite, though it remains equally important to emphasise that they belonged to the lower ranks of a local elite of a rather insignificant town. ${ }^{72}$ The problem

Augustine', Past \& Present 115 (1987), 3-51, at 16 on Augustine's later sermons against the practice. Note further that Augustine actually took a second concubine after the first had been sent away, because he had to wait to enter the marriage as the prospective bride was not yet of legal age; see Aug. Conf. 6.15.25 with Shaw, 45 .

69 As Werner Eck pointed out in the discussion during the conference in Rome, new recruits and soldiers may have travelled around in similar fashion.

70 D. Boin, 'Late antique Ostia and a campaign for pious tourism: epitaphs for bishop Cyriacus and Monica', Journal of Roman Studies 100 (2010), 195-208.

71 Aug. Conf. 9.11.28, with Tybout 2016, op. cit. (n. 39).

72 As Shaw 1987 , op. cit. (n. 68), 8 has argued convincingly against Brown 1967, op. cit. (n. 40), 21 concerning Augustine's claims in Aug. Conf. 2.3.5 that Patricius was of modest means, Augustine's family was certainly not poor, but belonged to a stratum of landowners with moderate wealth. 
is aggravated by the fact that the work itself invites to be read as a highly personal and spiritual journey. There also can be little doubt that Augustine was an extremely charismatic and towering figure-in many respects he was (and remains) larger than life. Not everyone will have had Augustine's immense talents, not everyone in this period will have been so desperately in search of religious truth. Nor would every young Roman have had a mother as strongwilled as Monica (or so one may hope).

\section{$5 \quad$ Anything Goes?}

In consequence, we have ended up with three different types of sources, all of which tell a rather different story about Roman migration. It seems difficult if not impossible to move out of this blind alley.

Obviously, more research could be done, in all three cases. More isotopic research could be done on the remaining skeletons of Isola Sacra, also by using different types of stable isotopes, and surely the discussion of third molars could be improved. The epitaphs and tombs of the Isola Sacra necropolis could be subjected to more rigorous scrutiny, and in particular the areas outside of the 100-tomb area could be taken into account (which would roughly double the amount of material). Also, more research could be done on Augustine, extending the analysis beyond the Confessiones, and taking other persons that circled around him into account as well. In all three cases we would be sure to gain a deeper understanding.

However, it can be doubted that further research will bridge the gaps between the three types of sources. In fact, it may be suspected that they will only be deepened. What we know about the context and representativeness of the three cases suggests as much. The isotopic findings are roughly in line with those from elsewhere. The Isola Sacra epigraphy presents a picture that is similar to that of many other Roman necropoleis. The movements of Augustine can be paralleled by those of many other intellectuals, also in the earlier period. More research may further understanding but is unlikely to solve the problem of the discrepancies.

Attempts to argue that the three cases somehow do not concern the same population seem forced. Economy of hypothesis suggests that the three types of sources cover roughly the same people in the same place. And even if they do not, it would not fundamentally alter the nature of the problem.

There is a possibility that the problems are particularly large because Ostia was a harbour city. Arguably, harbours not only attracted many migrants, but the temporary nature of migration may also have led, in a sense, to distortions 
and fluidity in recording practices. One may also point to the fact that epigraphic habits could differ from place to place. ${ }^{73}$ These are certainly valid points. It should be realised, however, that for the city of Rome a very similar case could be made to the one for Isola Sacra. Although its migrant epigraphy is infinitely richer, the numbers dwindle in comparison to the full epigraphic record of the city. ${ }^{74}$ The published isotopic analyses also do not square well with the epigraphic evidence. ${ }^{75}$

Be that as it may, there is no reason to privilege any of the three types of sources: all should be seen as empirical evidence, and all are marred by imperfections. Isotopic evidence clearly has the potential to uncover mobility that remains otherwise unmarked in the burial record, but its evidence is less direct and hard than it seems. Epigraphic evidence can show places of origin in a way which isotopic evidence will probably never be able to do, but we are dependent on the willingness of the commemorators to provide such information. A literary work like the Confessiones captures the dynamism that is so crucial to our understanding of mobility much better than the static snapshots from the burial record, but one might easily argue that eine Quelle ist keine Quelle. All three have so many inbuilt weaknesses that all three could logically be discarded on similar grounds.

It is possible to stop the argument here, and simply leave the inconsistencies for what they are. This could even be defended on philosophical grounds. It would be possible to embrace the epistemological anarchy advocated 40 years ago by Paul Feyerabend, who argued against the 'consistency condition' in the humanities and famously and polemically stated that "anything goes."76 But this also seems unsatisfactory, if not intellectually irresponsible. Such a position would come close to a post-modernist perspective on history that is ultimately inimical to scholarly research. In the end there is no choice but to try to reconcile the findings, or at least to use the combination of the findings to eliminate less likely inferences. ${ }^{77}$ In a discussion of a different subject, the

73 These points were brought up in the discussion in Rome. For variation within the epigraphic record, see Tacoma and Tybout 2016, op. cit. (n. 1).

74 The migrant epigraphy is analysed in full in D. Noy, Foreigners at Rome. Citizens and Strangers (London 2000).

75 Killgrove 2010 op. cit. (n. 5).

76 P. Feyerabend, Against Method. Outline of an Anarchistic Theory of Knowledge (London 1975), 28: "there is only one principle that can be defended under all circumstances (...): anything goes" (emphasis in the original).

I owe the latter point to Jeremia Pelgrom; the difference between the two may be conceptualised as a positive attempt at ironing out inconsistencies versus a negative process of elimination - the latter is attractive because it is less forced. 
historiography of ancient slavery, Niall McKeown approvingly quotes Georg Iggers, who wrote that

There is $(. .$.$) a difference between a theory that denies any claim to real-$ ity in historical accounts and a historiography that is fully conscious of the complexity of historical knowledge but still assumes that real people had real thoughts and feelings that led to real actions that, within limits, can be known and reconstructed. ${ }^{78}$

This belief in a historical reality that not only exists, but that also can be known within limits, could be backed up by the idea that there are various types of historical truth, or, in plain language, that each type of source tells a different part of the same story.

So how would such a story run? How can the findings be reconciled?

I believe that the percentage provided by the study of isotopes is in the right order, that is, that in Ostia roughly one-third of the population was born elsewhere, also because it corresponds with what we think we know about harbour cities. But, as the whereabouts of Augustine and Monica suggest, much migration was stepwise and many stays were temporary. Permanent resettlement was just one option among many others, and few free people who moved would have known at the outset that they were to resettle forever. Given this lack of permanence, where people were buried was to some extent dependent on chance. The lack of permanency may also explain to some extent why migrant origins were not always marked on epitaphs - though there is no direct link between permanency and inscribing migrant status. The prevalence of slaves in the epigraphy and tombs of Isola Sacra points to the issue of social and legal status. Surely some of the immigrants were brought to Ostia as slaves. This would go some way to explain the presence of 'children' in the isotopic evidence. For the younger part of the migrant population, slavery seems a better working hypothesis than family migration. But it does not explain the presence of women and children or sub-adults completely. Both epigraphy and the Confessiones suggest that the model of single male migrant was dominant

78 G. Iggers, Historiography in the Twentieth Century: From Scientific Objectivity to the Postmodern Challenge (Middleton 1997), 119, in a chapter significantly called "The "linguistic turn": the end of history as a scholarly discipline?', quoted by N. McKeown, The Invention of Ancient Slavery? (London 2007), 9. Note that the context of McKeown's extremely interesting discussion is slightly different from mine: he discusses competing but internally coherent interpretations of the same source, whereas here the issue is what to do with conflicting sources used to analyse the same historical reality. 
as a societal norm. Immigrants were supposed to be young adult males. At the same time, Augustine's case shows that some may have been travelling with families of concubines and sons, followed by slaves and, some, though no doubt fewer, will have been followed by widowed mothers.

Whether such a reconstruction is plausible is for others to decide. For the present purposes, the point is a different one. In offering such an interpretation, the room for manoeuvre is not infinite, but there is still considerable leeway. And that gives reason to pause. Not only do we have to take all available sources into account, as we no doubt all aim to do, but before we start to do so and before we start to create a coherent narrative, we would do well to analyse the inconsistencies first.

Leiden, November 2015 


\title{
Between Mobility and Connectivity in the Ancient Mediterranean
}

\author{
Coast-Skirting Travellers in the Southern Levant
}

Gil Gambash

Connectivity and Mobility

Forces of sea-bound connectivity in antiquity are believed nowadays to have been strong enough to overcome geographical barriers and unfavourable natural conditions; as well as to cross boundary lines once thought impenetrablebe it of cultural, political, or religious nature. ${ }^{1}$ And, within the sphere of connectivity, coastal seafaring - also referred to in professional literature as cabotage - gradually reveals itself to have been enduring, and to have functioned continuously, regardless of shifting circumstances. It is now considered by modern scholarship as one of the key agents of connectivity. The focus of the study of maritime activity in the ancient Mediterranean has thus shifted from large freighters, carrying high-value commodities from one major port to another along sea-crossing routes, to smaller vessels, operating locally, mostly along the coast, while servicing trade in elementary goods.

This understanding may have significant implications for the topic of this volume-particularly with regard to issues of mobility and empire-but not necessarily in the way that appears the most obvious. Direct links have often been drawn between Mediterranean connectivity and actual maritime mobility, to the effect that the two terms often seem to overlap in current discourse. But if, like commerce, much of mobility relied on cabotage, grave difficulties and limitations would have been imposed on travellers - certainly those who

1 Geniza documents have been famously shown by S.D. Goitein, A Mediterranean Society: The Jewish Communities of the Arab World as Portrayed in the Documents of the Cairo Geniza (Berkeley and Los Angeles 1967-1993) to disprove notions of a Muslim-Christian divide across the Mediterranean, as previously perceived by H. Pirenne, Mahomet et Charlemagne (Paris 1937). Theories of connectivity have reached their culmination with the publication of P. Horden and N. Purcell, The Corrupting Sea: A Study of Mediterranean History (Oxford 2000), $123-172$. 
crossed micro-regional boundaries. This assertion must also have implications for the imagined volume of passenger traffic in the Roman Mediterranean. ${ }^{2}$

Let us first be reminded of several conventions, that make up the building bricks of the idea of connectivity as we have come to perceive it in the past couple of decades: the Sea is the principal agent of connectivity; this makes the world of the Sea central, and, of necessity, leaves the terrestrial realm as marginal. This marginality increases with distance from water, to the extent that the very definition of distance may become inverted-connectedness through the Sea equals closeness, whereas the lack of interaction (even between neighbours) equals remoteness. The extent to which these assertions presume to encompass both commercial activity and human mobility is encapsulated in the following statement made by Horden and Purcell: "The main hindrance to the movements of people and goods by land has usually been social rather than physical." From this starting point, current scholarship often finds it selfevident and straightforward enough to read 'people' as 'masses of people' or even 'most people', rather than mere individuals. The movement of individuals and groups is thus depicted as omnipresent and continuous, and, most important, as varied in regard to its goals, geographical scope, and the identity and status of travellers. And this picture relies heavily on the assumed availability of maritime means of transportation.

But, to what extent can this hypothesis of omnipresent mobility be considered as compatible with the strong emphasis of our sources on cabotage? To be sure, the intensive, perennial activity of coast-skirting vessels may and should be regarded as a key player in the ancient Mediterranean economy, one that offered solutions of supply wherever and whenever demand in its various forms appeared. A picture of a dominant coast-based network, however, imposes on the actual mechanics of travelling a set of limitations that may have been overlooked in the process of generalization that has attached, all too easily, mobility to connectivity. Since most aspects of this phenomenonsave, perhaps, the average tonnage of ships-remain more or less constant throughout antiquity (and beyond), we may move freely along the temporal axis in search of relevant evidence.

2 Greg Woolf has recently risen to the challenge of offering much needed qualification and quantification to mobility in the ancient Mediterranean. His article may be read as a broader background to the focus placed here on cabotage: G. Woolf, 'Movers and stayers', in L. de Ligt and L.E. Tacoma, eds., Migration and Mobility in the Early Roman Empire (Leiden 2016), 440-463.

3 Horden and Purcell 2000, op. cit. (n. 1), 132. 
In a recent research project, for example, travelling in the late-antique west was examined through inscriptions. ${ }^{4}$ The corpus consists of 567 inscriptions recording foreigners and travellers-623 in number. 84 per cent of these people were men, mostly between the ages of 20 and 50 . A good number of them were nobles, bishops, and office holders; but also represented are sailors, soldiers, and, of course, merchants. To be sure, significant portions of the population are not represented in these lists, including individuals who the author, in the spirit of our times, assumes did travel, only without leaving their mark. In a Mediterranean world relying to a large degree on cabotage, such an assumption may not be made straightforwardly, certainly for the lower echelons of society.

\section{2 \\ Mobility and Physical Danger}

In order to be reminded of just how challenging travelling by sea could be, it may prove beneficial to return to the story of one of the most famous travellers in antiquity - Paul of Tarsus. Despite the wealth of detail on travelling in Paul's story, scholarship does not easily allow a balanced appreciation of his travels, since, when evaluating Paul's achievements, it often admires the general ease of travel in Roman times-in accordance with the prevalent picture of connectivity; and when scholars set to examine Paul's suffering during his travels, which he describes elaborately on a number of occasions, they approach his suffering as part of his spiritual struggle, and not necessarily as part of the routine of travelling. ${ }^{5}$

The well-known depiction of the shipwreck of Paul, when on his way to Rome for the last time, certainly adds colour to our discussion. The dangers and difficulties that were shared by the entire travelling population of the Mediterranean, especially insofar as inclement weather was concerned, are well documented in our sources, and sufficiently noticed by modern scholarship. ${ }^{6}$ This particular aspect of travelling was shared by vessels of all sorts ploughing the Mediterranean, big or small, coastal or open-sea, especially when sailing beyond the dates of the so-called 'sailing season'—now believed

4 M.A. Handley, Dying on Foreign Shores: Travel and Mobility in the Late-Antique West (Portsmouth, R.I. 2011).

5 R.S. Schellenberg, 'Danger in the wilderness, danger at sea: Paul and the perils of travel', in P.A. Harland, ed., Travel and Religion in Antiquity (Waterloo, Ont. 2011), 123-140.

6 For a discussion of shipwreck statistics see C. Hezser, Jewish Travel in Antiquity (Tübingen 2011), 167 . 
to have been far less rigid than we once used to believe-and outside the realm of the customary lanes, mostly dictated by the regime of winds. ${ }^{7}$

Shipwreck archaeology and written sources join to supply an elaborate picture of the dangers presented by unwelcoming weather to ships making their way along the coasts of the Mediterranean. ${ }^{8}$ Indeed, this danger appears to have existed also within the relative safety of natural anchorages, and even within the sphere of the great artificial harbours. In AD 62, 200 ships were sunk by a storm in the recently inaugurated harbour of Portus, near Rome. Centuries later, Procopius of Gaza reports that the poorly maintained harbour of Caesarea Maritima was similarly betraying its main function, seeing that ships were constantly being wrecked in the harbour itself. ${ }^{9}$

To be sure, underwater archaeology is less helpful when one turns to survey the impact of the weather over ships employing open-sea routes. Above all, the written sources offer a plethora of testimonies demonstrating the obvious difficulties that such voyages encountered. Josephus, when on his way to Rome, reports: ${ }^{10}$

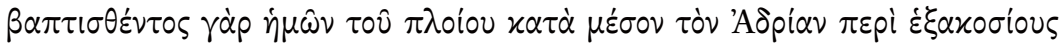

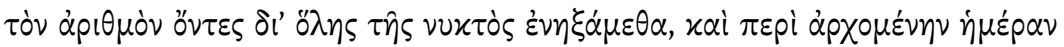

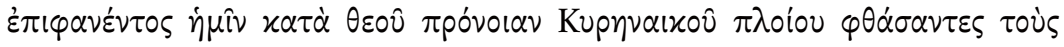

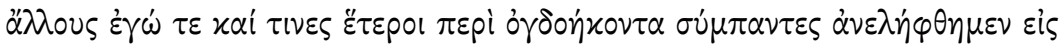
$\tau$ cò $\pi \lambda \circ \hat{\imath} \mathrm{ov}$.

As our ship was wrecked in the middle of the Adriatic Sea, being about six hundred people present aboard, we swam all night long; and upon the break of day, by God's providence, we saw a ship of Cyrene, and I and some others, about eighty altogether, outstripped the others, and were taken up into that ship.

7 Horden and Purcell 2000, op. cit. (n. 1), 137-143; J. Beresford, The Ancient Sailing Season (Leiden and Boston 2013).

8 Shipwreck stories were of course also part of storytelling repertoires, and have been studied as standardised narratives. See, for example, Schellenberg 2011, op. cit. (n. 5); B. Dunsch, 'Describe nunc tempestatem: Sea storms and shipwreck type scenes in ancient literature', in C. Thompson, ed., Shipwreck in Art and Literature: Images and Interpretations from Antiquity to the Present Day (London 2014), 42-59.

9 Tac. Ann. 15.18; Procop.Gaz. Pan. 19.

10 J. Vit. 14-16. All translations in this article are supplied by the author. 
The large size of the vessel described by Josephus is of significance, but even more interesting is the number of passengers on board, which, if reported correctly, would have made the vessel a large-scale ferry rather than the typical grain clipper, the latter usually hosting smaller numbers of travellers alongside its cargo. ${ }^{11}$

\section{$3 \quad$ Mobility and Cabotage}

One such grain clipper was the Isis, known to us from a dialogue by Lucian of Samosata, who relates: ${ }^{12}$

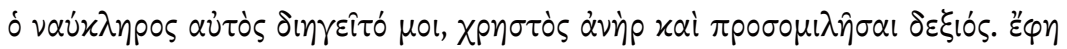

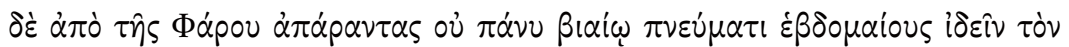

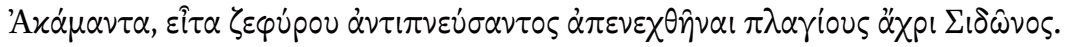

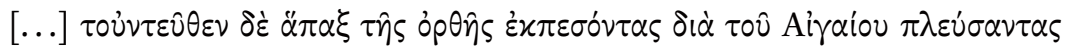

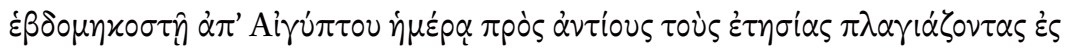

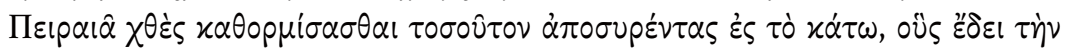

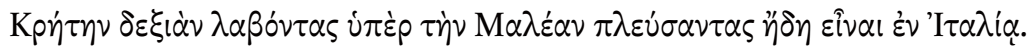

The captain himself described it to me, a nice man and good to talk to. He said that, when they left from Pharos, the wind did not blow too forcibly, and they sighted Akamas on the seventh day. Then a west wind blew against them, and they were carried east all the way to Sidon [...]. Having lost their proper course, they sailed across the Aegean against the Etesian winds, and seventy days after leaving Egypt they anchored yesterday in Piraeus, having drifted that far downwind. If they had kept Crete on their right, they would have sailed past Malea, and been in Italy by now.

11 The Nomos Rhodion Nautikos-hereafter NRN, used here after the 2001 reprint of W. Ashburner, ed., Rhodian Sea-Law (Oxford 1909) — a Byzantine Sea Law based on earlier Roman legislation, stipulates that each passenger should be allotted a deck-space of $1.875 \mathrm{~m}$. by $0.625 \mathrm{~m}$ ( $N R N 2.9)$. If abiding by such standards, the ship described by Josephus would have reached an imaginary size of $60 \mathrm{~m}$. by $12 \mathrm{~m}$. - not much smaller than the gigantic ships of Lake Nemi.

12 Luc. Nav.7-9. See L. Casson, 'The Isis and her voyage', Transactions and Proceedings of the American Philological Association 81 (1950), 43-56; and G.W. Houston, 'Lucian's Navigium and the dimensions of the Isis', The American Journal of Philology 108.3 (1987), 444-450. 
Significantly, the northern Etesian winds (known today also as the Meltemia), blow in the Aegean, often strongly and durably, throughout the summer-the very time of the sailing season. To be sure, such reports emphasize the difficulties and dangers experienced also by larger ships as a result of shifty weather. Interestingly, by demonstrating the need of these ships for constant improvisation, they offer an expansion of the very sphere of cabotage as it is employed today, to include also large ships, originally headed towards large artificial harbours along fixed routes-often across the open sea. ${ }^{13}$

While, in its strict sense, cabotage refers solely to coast-skirting activityand, in effect, is still employed as such in the French-speaking academic discourse-it has come to represent for us a broader phenomenon, essentially epitomized in the great flexibility of vessels and seamen in antiquity to act beyond the limitations allegedly imposed on them by natural as well as political circumstances. ${ }^{14}$ As stated in the opening of this article, this flexibility is usually ascribed to smaller ships, and is studied through their perspective. There is no reason why we should not include also significant parts of the activity of larger ships in this sphere.

The details leading towards the shipwreck of Paul may serve well to demonstrate this point, and should be observed closely—not necessarily because they offer an authentic description of a historical event, but because they represent a plausible depiction which would have applied in cases of similar background..$^{15}$ Looking for a way to travel from Lycian Myra to Rome, the centurion escorting Paul found an Alexandrian ship sailing for Italy, and put them on board. The ship must have been significant in size and, due to its place of origin, we may easily imagine that it carried grain. No less than 276 people are said to have been on board. Though starting its way still within the sailing season, the ship encountered unwelcoming weather, and dawdled off the coasts of southwestern Asia Minor (Cnidus), and then Crete (Salmone and Lasea).

Finding themselves in a harbour in southern Crete that was not suitable for the upcoming winter, and with the last days of the sailing season now past, the owner of the ship and its pilot decided to pursue their journey, hoping at the very least to make it to the harbour at Phoenix. ${ }^{16}$ It was then that the

\footnotetext{
13 P. Arnaud, Les routes de la navigation antique: Itinéraires en Méditerranée (Paris 2005).

14 On cabotage as a mere technique of navigation see X. Nieto, 'Le commerce de cabotage et de redistribution', in P.A. Gianfrotta et al., eds., La navigation dans l'Antiquité (Aix-enProvence 1997), 146-159.

15 Act.Ap. 27.1-28.5.

16 Paul is said to have suggested, contrary to the judgment of the pilot and the ship-owner, that the season was not appropriate for sailing, the day of atonement having already
} 
storm and shipwreck occurred. Much of Paul's journey as it is described up to this point matches the fundamental characteristics of cabotage, quite regardless of the nature of the various harbours of departure, the size of the ship employed, and the planned routes. Time and again, the journey, undertaken mostly along the coast, encounters challenging weather, which necessitates a variety of improvised measures, including updating planned routes, anchoring in inappropriate or unsafe harbours, and sailing beyond the dates of the customary sailing season.

\section{4}

\section{The Southern Levant}

The challenges with which Paul's journey was faced, still before the shipwreck itself took place, would have comprised a significant part of the sailing routine in the ancient Mediterranean. But we must pay attention here not only to the difficulties imposed by weather, but also, and perhaps more crucially, to the tribulations caused by the system itself. If a significant part of the volume of maritime activity in antiquity may be ascribed to coastal skirting, then not only trade, but travel itself, must be imagined to have been embedded within this particular sphere. What exactly did it imply to coast-skirt around the Mediterranean?

In a catalogue of ancient Mediterranean shipwrecks, compiled in 1992, more than 1,200 items were documented-some of which were excavated thoroughly while others were only superficially surveyed. ${ }^{17}$ Today, the number of known shipwrecks for the Mediterranean in its entirety must exceed 2,00o, and an update for Parker's catalogue would be most welcome. While finds of shipwrecks are usually locally contextualized, the magnitude of the numbers has occasioned the emergence of generalisations on a broader scale. ${ }^{18}$

Most relevant to our discussion here, the majority of shipwrecks dated to antiquity may be considered small or medium in size. ${ }^{19}$ While the average

passed (Act.Ap. 27.9-11). For the sailing season see also Ph. Post. Cain. 7.22; Leg. ad Gaium 3.15. Philo shows himself aware of the dangers of sailing beyond "the beginning of Autumn", yet he sails with his delegation to meet Caligula in mid-winter.

A.J. Parker, Ancient Shipwrecks of the Mediterranean and the Roman Provinces (Oxford 1992).

18 E.g. M. Jurisic, Ancient Shipwrecks of the Adriatic (Oxford 2000). For the development of maritime archaeology more generally, and current approaches to the research of shipwrecks, see D. Gibbins and J. Adams, 'Shipwrecks and maritime archaeology', World Archaeology 32.3 (2001), 283-287.

19 Woolf 2016, op. cit. (n. 2), 461-462. 
tonnage of Mediterranean ships rises and drops during certain periods in antiquity, it remains in the area of several dozens tons, and never soars to represent a significant shift towards larger ships. ${ }^{20}$ Papyri from Egypt support this picture. The Customs Account, discovered under an Aramaic text from Elephantine, contains a list of 42 ships - 36 Ionian Greek and 6 Phoenicianimporting in the year $475 \mathrm{BC}$ a variety of goods to a harbour in the Nile Delta, from where they exported, all without exception, mineral soda for the textile industry. ${ }^{21}$ Most of the ships on the list are estimated to have been small, which prompts Horden and Purcell to identify them as acting within the sphere of cabotage, despite the high value of their cargo, and our lack of knowledge regarding the actual routes they had taken on their way to and from Egypt. ${ }^{22}$ Another example, the famous P. Bingen 77, includes a shorter list of 12 ships, arriving in an unspecified harbour in the Nile Delta sometime in the second century AD. ${ }^{23}$ Here the tonnage for nine ships is mentioned in units of artaba, and, save one large vessel hailing from Ostia, all may be considered small or medium in size. ${ }^{24}$

Let us turn our focus to Paul's customary area of departure, the south-eastern corner of the Mediterranean, and to its respective maritime heritage. Firstly, it must be noted that the shores of the Southern Levant are unanimously considered to have been challenging to pre-modern seafarers. The reasons for this are varied, and include the dominant western vector of local winds, and the paucity of natural harbours along the coastline. Local ancient societies were

20 E. Nantet, Le Tonnage des navires de commerce en Méditerranée du VIIIe siècle av. l’è. chr. au VIIe siècle de l'è. chr. (Rennes 2016). See also D. Rathbone, 'The financing of maritime commerce in the Roman Empire, I-II AD', in E. Lo Cascio, ed., Credito e moneta nel mondo romano (Bari 2003), 210-225; A. Tchernia, 'L'utilisation des gros tonnages', in W.V. Harris and K. Iara, eds., Maritime Technology in the Ancient Economy: Ship-Design and Navigation (Portsmouth 2011), 83-88.

21 B. Porten and A. Yardeni, Textbook of Aramaic Documents from Ancient Egypt, vol. 3, Literature, Acounts, Lists (Jerusalem 1993), §C3.7.

22 O. Tal, 'On the identification of the ships of $K Z D / R Y$ in the erased customs account from Elephantine', Journal of Near Eastern Studies 68.1 (2009), 1-8; P. Briant and R. Descat, 'Un registre douanier de la satrapie d'Égypte à l'époque achéménide', in N. Grimal and B. Menu, eds., Le commerce en Égypte ancienne (Paris 1998), 59-104; Horden and Purcell 2000, op. cit. (n. 1), 149.

23 P. Heilporn, 'Registre de navires marchands', in J. Melaerts, ed., Papyri in honorem Johannes Bingen octogenarii (Leuven 2000), 339-359.

24 Arnaud 2005, op. cit. (n. 13), 35. 
well aware of the challenging characteristics of the shoreline, as indicated by Josephus' report: ${ }^{25}$

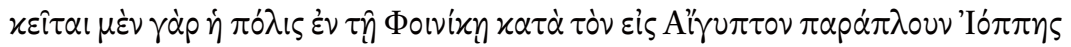

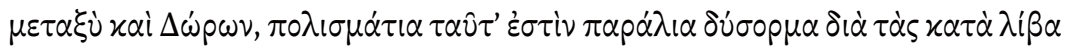

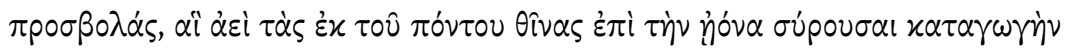

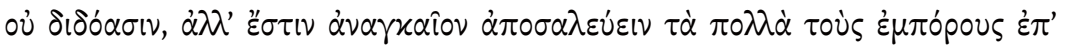
àrúpas.

This city [i.e. Strato's Tower] is situated in Phoenicia, on the sailing route to Egypt, between Joppa and Dora, which are coastal towns with inappropriate anchorage, on account of the attacks of the winds upon them, which, dragging the sand from the sea to the shore, do not allow the landing of ships, and the merchants are forced for the most part to anchor in the open sea.

Nevertheless, the challenging nature of the coast need not indicate that maritime activity in the area was less intense than in other stretches of Mediterranean shores. By the early 1990 os some thirty shipwrecks were recorded along the shores of the Southern Levant. And since the publication of the shipwreck catalogue, underwater work has resulted in the discovery and careful study of more than a dozen additional shipwrecks. The total of the finds, then, may be taken to represent the current picture of shipwreck archaeology in Israel. It is presented in Table 1, broken up into rough periodization. ${ }^{26}$

It is not a straightforward task to learn from this corpus more about options of mobility for locals and visitors during antiquity. Travelers left almost no trace in the archaeological record, and the written reports are significantly more reticent about the actual technicalities of travelling than they are on shipwrecking. From the silence of such sources as the Rhodian Sea Law, we

25 J. AJ 15.333. For a survey of the geography of the area and changes in its coastline see A. Raban, 'The heritage of ancient harbor engineering in Cyprus and the Levant', in V. Karageorghis and D. Michaelides, eds., Proceedings of the International Symposium Cyprus and the Sea (Nicosia 1995), 139-141.

26 See Table 1. The shipwrecks that were discovered until 1992 are documented in Parker 1992, op. cit. (n. 17), nos.: 1; 2; 3; 26; 27; 61; 136; 137; 138; 367; 494; 495; 503; 504; 505; 525; 540; 541; 612; 689; 690; 697; 700; 739; 740; 741; 809; 1069; 1078; 1115. For shipwrecks excavated since 1992 see below. 
may deduce that travellers played a lesser part in the maritime sphere than commercial cargo, at least as far as the official authorities were concerned. ${ }^{27}$

Indeed, in a great number of cases where passengers are referred to in the official legislation, they are specified to be merchants travelling with their merchandise, and sharing in the responsibilities for the handling of the cargo and the ship's welfare. In one place in the Rhodian Sea Law, the captain is to consult merchants with goods on board should the need for jettison arise; an ultimate decision is made by the vote of all merchants on board. Another reference to the topic discloses the mutual responsibility of captain and merchant for compensation in the case of the loss of a ship. ${ }^{28}$ One is reminded of Paul's plea to the captain not to continue the voyage on account of the late

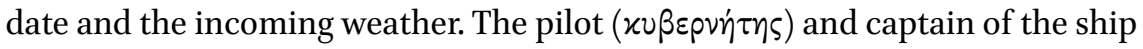

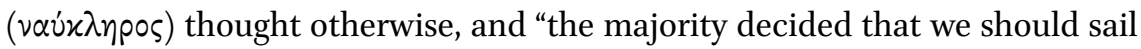
on."29 The group that voted must have consisted of merchants travelling with their cargo, the same cargo that soon would be thrown overboard with the rise of the tempest.

Perhaps surprisingly, we do not find too much evidence for shipwrecks in Caesarea-the reported point of departure for some of the more famous individuals of the period, among them Herod, Paul, and Josephus. But here is the point to wonder about the actual significance of the size and sophistication of the harbour of Sebastos at Caesarea for the topic of individual mobility. If most of the options that were available for sea-bound travellers relied on smaller, coast-skirting vessels, then Caesarea's glamorous advantages would have been rendered irrelevant, and the gigantic artificial harbour may have been considered as just another anchoring possibility among a variety of smaller harbours and natural anchorages located along the coasts of the Southern Levant. The

27 Greg Woolf estimates - very provisionally — that in any given year only one person in a thousand travelled over long distances. See Woolf 2016, op. cit. (n. 2), 462.

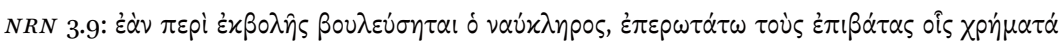
$\dot{\varepsilon} \sigma \tau \imath \nu \dot{\varepsilon} \nu \tau \hat{\omega} \pi \lambda \circ i \omega$. jettison, let him consult the passengers who have goods on board; and let them put it to

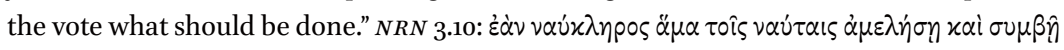

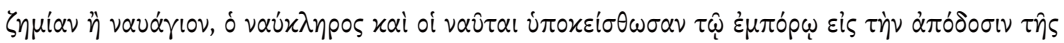

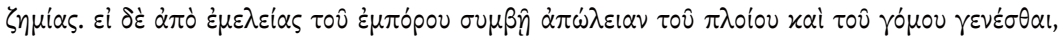

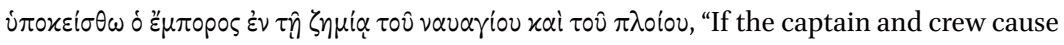
damage or shipwreck out of neglect, let the captain and crew be responsible to the merchant for covering the damage. If it is as a result of the merchant's negligence that the ship and the cargo are destroyed, let the merchant be responsible for the damage caused by the shipwreck." 
fact that Sebastos would have been a lively hub of transportation on account of its size and centrality, while it would have served as an advantage for some ship-owners and travellers, could just as well have been an impediment and a hindrance to others - finding, perhaps, such centrality less affordable, or too closely regulated by the authorities. ${ }^{30}$

\section{$5 \quad$ Dor}

The city of Dor, located only $15 \mathrm{~km}$ to the north of Caesarea, serves as an important source of information in this investigation, having along its shores several bays and lagoons that would have served as natural anchorages to smaller vessels, and offering abundant evidence of shipwrecks. ${ }^{31}$ In preliminary surveys undertaken in a lagoon located to the south of the Tel, several sites were marked as potentially hosting a shipwreck. ${ }^{32}$ The lagoon, it should be highlighted, shows no indication of port facilities. Systematic work was begun later in the 199os to excavate and document as many of the shipwrecks of the lagoon as possible. It is a remarkable fact that seven of the shipwrecks that have been carefully studied so far have been dated to a period loosely matching that of Late Antiquity. Indeed, of the dozen shipwrecks excavated since the early 1990s, these seven are the only representatives of antiquity. ${ }^{33}$

Generalising from this group should be approached with caution, since there is much about them that remains unknown. Still, it may be said that the size of these ships ranges from small to medium, and their capacity may reach

30 The much neglected southern bay of Caesarea is another case in point, as there are indications that it served maritime needs at the same time as Sebastos, much in the way Dor did. For now all that was published on the site may be found in E. Galili, U. Dahari and J. Sharvit, 'Underwater surveys and rescue excavations along the Israeli coast', The International Journal of Nautical Archaeology 22 (1993), 65-69.

31 For an initial summary of the results of surveys conducted in the area of Dor between 1976 and 1991 see S.A. Kingsley and K. Raveh, The Ancient Harbour and Anchorage at Dor, Israel (Oxford 1996); see also a review by Bass: G.F. Bass, 'Review: Sean A. Kingsley and Kurt Raveh, The Ancient Harbour and Anchorage at Dor, Israel', Biblical Archaeologist 60 (1997), 57.

$32 \quad$ Kingsley and Raveh 1996, op. cit. (n. 31), 55-75. See map of Dor below.

33 See Table 2. The shipwrecks — all but Dor 2006 - are presented en masse and discussed from a technological point of view by Y. Kahanov, 'Ancient shipwrecks in the lagoon of Dor (Tantura) and their meaning' (Heb.), Katedra 134 (2010), 6-24; see also Y. Kahanov, 'Ship reconstruction, documentation and in situ recording', in A. Catsambis, B. Ford and D.L. Hamilton, eds., The Oxford Handbook of Maritime Archaeology (Oxford 2011), 169-181. 
as high as a few dozen tons. All of the ships could navigate in shallow waters, which made lagoons and natural anchorages viable anchoring locations. This would have made all of them suitable for improvised coastal activity.

Almost none of these ships yielded clear indication regarding their cargo. They could of course have foundered empty; or the goods on board could have been carried by currents or perished in the run of time. Salvaging, though, was common enough in antiquity, and well-supported by particular legislation. The Rhodian Sea Law goes as far as to enumerate the reward owed to salvours who abide by the law. The closeness of most of the shipwrecks to the shore makes this option the one most likely to have taken place. ${ }^{34}$

The reason for the presence of these ships in Dor's lagoon is still a debated issue. ${ }^{35}$ The difficulty arises from archaeological and literary evidence, testifying to the sudden disappearance of Dor from the map of local coastal settlements by the middle of the third century. The archaeological and literary records are unequivocal about the complete cessation of activity on the Tel by the middle of the third century. ${ }^{36}$ The last coins known to have been minted at Dor are from the Severan period. ${ }^{37}$ It is possible, however, that a smaller, more modest version of the settlement continued to exist on the eastern slopes of the Tel. ${ }^{38}$ And on the same slopes a large Christian basilica was discovered, which was built in the middle of the fourth century, and served as the local episcopal seat well into the Muslim period. ${ }^{39}$ The importance of the basilica in the local scene cannot be overlooked, and is evidenced by its monumental size, and the fact that it served as a xenodocheion..$^{40}$ It also hosted two graves of

$34 \quad N R N$ e.g. 45-47. An exhaustive discussion of primary sources on the topic may be found in the introduction of Ashburner 1909, op. cit. (n. 11), cclxxxviii-ccxciii.

35 G. Gambash, 'Maritime activity in the ancient southern Levant: The case of Late Antique Dor', ARAM 27 (2015), 61-74.

36 E. Stern, Dor: Ruler of the Seas (Jerusalem 1994), 319-323. See also Eus. Onom. under Dor

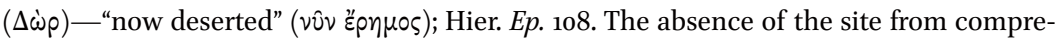
hensive surveys of the area is also telling, e.g. the Bordeaux Pilgrim 585; Al-Muqaddasi (trans. G. le Strange), Description of Syria, Including Palestine (London 1886), 12-65 (particularly pp. 53-55).

37 Israel Numismatic Journal 9 (1986-7), no. 44 (Julia Domna); and no. 52 (Plautilla).

38 C. Dauphin and S. Gibson, 'The Byzantine city of Dor/Dora discovered', Bulletin of the Anglo-Israel Archaeological Society 14 (1994), 9-38.

39 C. Dauphin, 'On the pilgrim's way to the holy city of Jerusalem: The basilica of Dor in Israel', in J.R. Bartlett, ed., Archaeology and Biblical Interpretation (London 1997), 145-165.

40 For the topic, see O.R. Constable, Housing the Stranger in the Mediterranean World (Cambridge 2006). 
saints, and sacred relics from Golgotha, and we must assume that it appeared on such pilgrimage maps as the fragmental one discovered at Madaba. ${ }^{41}$

There is, however, a major problem in ascribing the presence of ships in late antique Dor to the pilgrimage movement. The mere economy of the ship trade probably would not have allowed revenues based on taxi services alone to support the costs of a sea voyage, let alone produce profit to ship owners. Contemporary documentation sheds light on the extent to which ship owners relied for profit on the transportation of goods. The Rhodian Sea Law, as shown above, concentrates almost exclusively on issues of profit from trade, while referring to passengers mostly under their capacity as tradesmen travelling with their merchandise. It could, for example, offer solutions to the common enough situation of passengers who did not make it to their intended destination, and to the question of compensation in such cases.

It may, however, prove fruitful to turn our gaze towards Dor's immediate hinterland, and to note the vibrant commercial activity that was conducted there, and that would have made good use of Dor's natural anchorages. For the Byzantine period, more than a hundred sites indicate activity in Dor's immediate surroundings alone. ${ }^{42}$ And during the early Muslim period, though economic activity as well as population size dwindled dramatically, the Dor area nevertheless remained populated and active, and contemporary archaeological finds, consisting mostly of pottery and buildings, have been discovered in more than a dozen sites. ${ }^{43}$ One major focus of activity would have been a Muslim fortress, built in Kafr Lam soon after the Arab conquest. ${ }^{44}$

The shipwrecks of Dor suggest that coastal trade routes along the Southern Levant remained open and active regardless of the shifting political and economic circumstances. Dor's southern lagoon was hardly an ideal docking spot, yet it was one that complied in nature with the period's seafaring activity across the Mediterranean, consisting for the most part of smaller ships, regularly occupied in coastal activity. And, of course, it is not Dor alone that is the issue here, rich in shipwrecks as the site may be. Shipwrecks from the Byzantine period, for example, were also discovered in Hof Hakarmel, Sdot

41 For the holy graves see Dauphin 1997, op. cit. (n. 39), 160. For the relics of Golgotha see CIIP 2117 (pres. loc.: Israel Museum, Jerusalem, IAA inv. No. 1952-1153). For the Madaba Map see H. Donner, Die Mosaikkarte von Madeba (Wiesbaden 1977).

42 J. Olami, S. Sender, and E. Oren, Map of Dor (3o) (Heb.), (Jerusalem 2005).

43 For economic and demographic decline see C. Dauphin, La Palestine byzantine: peuplement et populations, vol. I, (Oxford 1998), 349-525. For populated sites in the area see Olami, Sender and Oren 2005, op. cit. (n. 42). 
Yam, Newe Yam, and Mikhmoret. ${ }^{45}$ Now that we know of the ships from Dor there is no reason to think that the shores of the Southern Levant did not witness maritime activity during the early Muslim period. ${ }^{46}$ Dor's uniqueness, as far as this research is concerned, lies in the relatively large number of ships that foundered in its southern lagoon during Late Antiquity.

It would have been sites such as Dor's lagoon, and ships similar to the ones that were wrecked in it, that would have represented travelling in the ancient Mediterranean in its most commonly available form. Indeed, it remains highly debatable whether larger ships frequented the shores of the Southern Levant in significant numbers at all. More than a few hypotheses have been suggested for explaining the building of the massive artificial harbour of Sebastos at Caesarea. ${ }^{47}$ One such hypothesis relates to the large freighters, known to have served the grain demands of Rome on the line between Alexandria and Italy. There are significant problems in ascribing central planning to the institution of the annona. Here too market forces of demand can be seen as the main motivators behind the significant efforts witnessed all around the Mediterranean to bring grain in sufficient amount to Rome. The proponents of a grand strategic organization of the annona assume, however, that the central government-Augustus and Agrippa themselves, in our case-was involved in facilitating the grain flow. ${ }^{48}$ The harbour at Caesarea, according to this hypothesis, was conceived and built in order to supply another stop on the way from Alexandria to Syria, notorious for its lack of harbours and natural havens.

The question to be asked here is to what extent the grain freighters, which often took sea-crossing routes, actually required frequent stops, or at least immediate possibilities for security, in the case of bad weather. The text of Lucian of Samosata, quoted above, offers revealing details regarding the route preferred by one of the few skippers whose voice is heard in the sources. Before losing its course, it is stated in the dialogue, the ship initially made

45 Parker 1992, op. cit. (n. 17): Hof Hakarmel, no. 505; Sdot Yam, no. 1069; Newe Yam, no. 740; Mikhmoret, no. 697 .

46 It would have been tempting to assume, prior to the recent excavations, that the volume of maritime traffic in the southern Levant during the early Muslim period was meagre.

47 G. Gambash, 'Caesarea Maritima and the grand strategy of the Roman Empire', Skyllis 13.1 (2013), 53-58.

48 For discussion see e.g. H.K. Beebe, 'Caesarea Maritima: its strategic and political significance to Rome',Journal of Near Eastern Studies 42.3 (1984), 195-207; G.E. Rickman, 'Towards a study of Roman ports', in A. Raban, ed., Harbour Archaeology (Oxford 1985), 105-114; A. Raban, The Harbour of Sebastos (Caesarea Maritima) in its Roman Mediterranean Context (Oxford 2009), 1-13. 
it, with a moderate wind, from Alexandria to Cyprus - to Akamas, the cape at the northwest extremity of the island. The journey lasted seven days, and this amount of time indicates beyond doubt that the ship sailed on a direct course, through the open sea, and not, as is usually assumed for ships leaving Alexandria, along the shores of the Levant. ${ }^{49}$

The reality described in Lucian's dialogue, written around the year 150, may be seen to represent the first and second centuries $\mathrm{AD}$, when the traffic of the grain freighters was at its height. It is hard to imagine what role the harbour of Caesarea would have played in such a routine, 'cutting the corner'-so to speak - of the entire eastern-Mediterranean coast in favour of a shorter, faster route to Rome. If that was the habit of most Alexandrian freighters, the traffic of larger ships along the coasts of the Southern Levant would have been significantly scarcer than current estimations suggest.

\section{$6 \quad$ Conclusion}

This article opened in pointing out the pronounced parallelisation that prevails in current scholarship between connectivity and mobility. It was then suggested that many of the difficulties usually ascribed to sea-voyages in antiquity are outlined in light of the physical dangers therein. It is the combination of both that prevents a more accurate evaluation of the difficulties presented to the average ancient traveller, not by bad weather, but by the versatile structure of the system, based as it was on the improvised and arbitrary movement of those main vehicles of transportation-the vessels of cabotage.

The great majority of travel reports from antiquity are supplied in the form of itineraries, simply indicating points of departure and arrival. ${ }^{50}$ In order to introduce some nuance to these reports, and learn about the technicalities of such journeys-going beyond the odd event of unwelcoming weather-we must look carefully for evidence that breaks up the journey into finer details. In the case of Paul, who is believed to have travelled 10,000 miles around the Mediterranean before being transported to Rome, it is the very broken nature

49 Calculations suggest that the direct route to Cyprus would have taken five days at the minimum; whereas sailing along the Levantine coast would have lasted no less than two weeks, and that while sailing also during nighttime. The calculations are based on W. Scheidel and E. Meeks, ORBIS: The Stanford Geospatial Network Model of the Roman World (http://orbis.stanford.edu). 
of the journey that sheds revealing light on the process. ${ }^{51}$ When returning, for example, from Miletus to Caesarea, Paul first had to sail to Kos, and on the next day continued from there to Rhodes and then to Patara. In Patara he found a ship that took him to Syria via Cyprus. This ship was to unload its cargo in Tyre, and Paul stayed in the city for a week before continuing his journey, to Ptolemais, and from there, after another break, to Caesarea.

Even when sent from Caesarea by the Roman governor of Judea to stand trial in Rome, Paul was forced to make his way in sections. All that was managed for the transportation of the prisoner-in all the glorified harbour of Caesareawas a ship of Adramytium, which was headed to "places along the coast of Asia." 52 The ship probably belonged to the smaller category of coast-skirting vessels, such as the ones discovered in Dor. It stopped in Sidon, and continued via Cyprus to Asia Minor. Only in Myra was the centurion escorting Paul able to find a ship headed for Rome. Such would have been the tribulations of travelling by sea in antiquity. Most assuredly, any individual would have found it possible to make his or her way from point A to point B almost anywhere across the Mediterranean. The infrastructure of connectivity, consisting in dense networks of maritime movement of all sorts-but perhaps of cabotage above all —would have warranted the viability of every such trip, just as it would the circulation of news and the dissemination of knowledge, the redistribution of surpluses and, basically, the usually successful matchmaking between demand and supply. But, while connectivity would have guaranteed communications, the spread of new technologies, or the consumption of anything from luxuries to locally unavailable necessities, it did not correspond to the extensive, omnipresent movement of individuals. For mobility, connectivity merely served as potential only occasionally—or, indeed, almost seldom—realised.

Haifa, December 2015

51 W.A. Meeks, The First Urban Christians: The Social World of the Apostle Paul (New Haven and London 1983), 16.

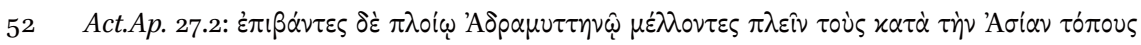
$\dot{\alpha} \nu \eta \dot{x} \vartheta \eta \mu \varepsilon v$. 


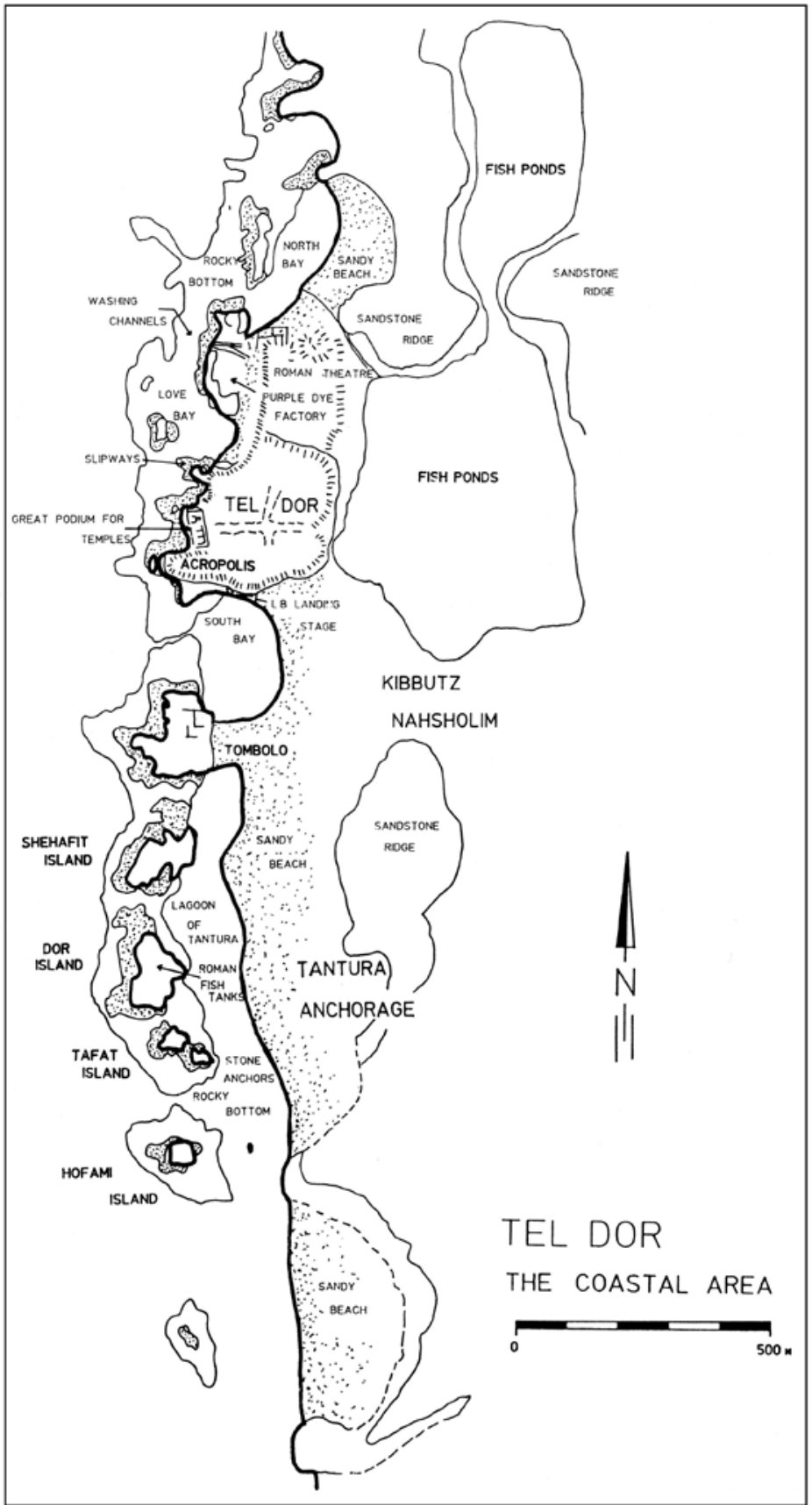

MAP 9.1 A plan of Tel Dor, its bays, and the Tantura lagoon. After A. Raban, 'The Harbour of the Sea Peoples at Dor', The Biblical Archaeologist 50.2 (1987), 118-126. 
TABLE 9.1 Shipwreck archaeology in Israel differentiated chronologically in number of shipwrecks found $(N=44)$

\begin{tabular}{lclc}
\hline Date (centuries) & Discovered up to 1992 & Discovered since 1992 & Current Total \\
\hline M B & 1 & - & 1 \\
LB & 3 & - & 3 \\
Iron & 1 & 2 & 3 \\
$6-4$ BC & 6 & - & 6 \\
$3-1$ BC & 5 & - & 5 \\
$1-3$ & 6 & - & 6 \\
$4-6$ & 5 & 3 (Dor) & 8 \\
$7-9$ & 1 & 4 (Dor) & 5 \\
Later & 3 & 4 & 7 \\
Totals & $\mathbf{3 1}$ & $\mathbf{1 3}$ & 44 \\
\end{tabular}

TABLE 9.2 The late antique shipwrecks of Dor

\begin{tabular}{|c|c|c|c|c|}
\hline & $\begin{array}{l}\text { Date } \\
\text { (century AD) }\end{array}$ & Size & $\begin{array}{l}\text { Building } \\
\text { Technique }\end{array}$ & Cargo \\
\hline Dor D & mid 4-early 7 & Medium? & Shell based & Personal \\
\hline Tantura A & late $5^{- \text {early } 6}$ & Small & Frame based & Personal \\
\hline Dor $2001 / 1$ & early 6 & $17.5 \mathrm{~m}$ & Frame based & $\begin{array}{l}\text { Personal + } \\
\text { Building Blocks? }\end{array}$ \\
\hline Dor 2006 & $5^{-6}$ & Medium? & Frame based & Personal \\
\hline Tantura F & mid 7 -late 8 & $16 \mathrm{~m}$ & Frame based & $\begin{array}{l}\text { Personal + Fish } \\
\text { Products? }\end{array}$ \\
\hline Tantura E & $7-9$ & $?$ & Frame based & Personal \\
\hline Tantura B & early 9 & $18-23 \mathrm{~m}$ & Frame based & Personal \\
\hline
\end{tabular}




\title{
The Dangers of Female Mobility in Roman Imperial Times ${ }^{1}$
}

\author{
Margherita Carucci
}

\section{1 \\ Introduction}

Recent work on mobility and migration in the Roman empire offers many useful insights into the dynamics of ancient travel, even though the subject of women and travel specifically has been addressed in only limited, albeit useful, ways. ${ }^{2}$ Though women's opportunities for stepping out of the house and travelling on a short or long journey were much more restricted and limited in range than those of the mobile man, Roman imperial women did travel more often than we used to think. Yet the image of the woman who centres her life on her family and restricts her daily activities to those within the domestic walls was an ideal that never lost its power and attraction in Roman society, even in imperial times, when the changing political and social circumstances gave especially upper-class women more opportunities for stepping into the more public (and male) sphere of politics and power.

The traditional ideal of domestic focus for Roman women is the framework within which senators were asked to evaluate the proposal that Aulus Caecina

1 I would like to thank the editors for their invitation to participate in this volume. I am most grateful to Rens Tacoma who helped to develop my argument with his insightful comments on earlier drafts of this paper. I also thank Miriam Groen-Vallinga for her helpful suggestions and stylistic improvements. Any remaining errors are my own.

2 See, for instance, the section 'Mobility' in E.A. Hemelrijk and G. Woolf, eds., Women and the Roman City in the Latin West (Leiden and Boston 2013) with contributions by Woolf 'Female mobility in the Roman West', 351-368, E.M. Greene, 'Female networks in military communities of the Roman West: A view from the Vindolanda tablets', 369-390, and L. Foubert, 'Female travellers in Roman Britain: Vibia Pacata and Julia Lucilla', 391-403; and also contributions in L. de Ligt and L.E. Tacoma, eds., Migration and Mobility in the Early Roman Empire (Leiden 2016): C. Bruun, 'Tracing familial mobility: Female and child migrants in the Roman West', 176-204, S. Hin, 'Revisiting urban graveyard theory: migrant flows in Hellenistic and Roman Athens', 234-263, L. Foubert, 'Mobile women in P. Oxy. and the port cities of Roman Egypt: Tracing women's travel behaviour in papyrological sources', $285^{-304}$, and L.E. Tacoma and R.A. Tybout, 'Moving epigrams: Migration and mobility in the Greek East', $345-389$. 
Severus made in the Senate in AD 21. In Annales 3.33-34, Tacitus reports that in the course of a debate in the Senate "Caecina proposed that no magistrate who had obtained a province should be accompanied by his wife." ${ }^{3} \mathrm{He}$ argued that

Haud enim frustra placitum olim, ne feminae in socios aut gentes externas traherentur; inesse mulierum comitatui quae pacem luxu, bellum formidine morentur et Romanum agmen ad similitudinem barbari incessus convertant. non imbecillum tantum et imparem laboribus sexum sed, si licentia adsit, saevum, ambitiosum, potestatis avidum.

Not without reason it was formerly agreed that women were not to be taken among our allies or into foreign countries; it is inherent to the train of women who delay peace through luxury and war with fear and who convert a Roman army on the march into the likeness of a barbarian procession. Women are not only feeble and unequal to hardship but, when they are not under control, also fierce, ambitious, and greedy of power.

Caecina's proposal was opposed by Valerius Messalinus, who argued that

neque enim, ut olim, obsideri urbem bellis aut provincias hostilis esse; et pauca feminarum necessitatibus concedi, quae ne coniugum quidem penates, adeo socios non onerent; cetera promisca cum marito nec ullum in eo pacis impedimentum. bella plane accinctis obeunda: sed revertentibus post laborem quod honestius quam uxorium levamentum?

Rome is not longer beset with wars, as in the past, nor are the provinces hostile. A few concessions were made to the women, but they were not a burden to their husbands' home, not even to our allies; in all other respects a woman who lived in intimacy with her husband was not an impediment to peace. Certainly wars require men ready to go and fight, but when they return home after their hardships, what is worthier than their wives' consolation?

Messalinus' rebuttal was supported by Drusus, who closed the debate with a few words on his own experience as a husband. After mentioning the precedent of Augustus, who had been often accompanied by his wife Livia when

3 Tac. Ann. 3.33: Severus Caecina censuit, ne quem magistratum cui provincia obvenisset uxor comitaretur. Translations are my own. 
he visited the provinces, Tiberius' son admitted his reluctance to be separated from the mother of his children if serving in foreign countries.

This debate as reported by Tacitus has raised much discussion among scholars. ${ }^{4}$ Here I would like to highlight the opposition between two different trends in Roman social attitudes towards women's mobility. Caecina's proposal reinforces the timeless value of the mos maiorum that was based on a rigid division of gender roles: men act in the public realm of politics and military while women perform their duties as devoted wives and good mothers inside the house. The speeches delivered by Messalinus and Drusus, by contrast, stress the importance of concordia between wife and husband: if political or military duties force a man to spend a long time away from his country, it is a wife's duty to leave the house and travel with her husband as his devoted companion. Drusus' mention of Augustus' practice of being accompanied by Livia on his travels, as well as the literary and epigraphic evidence, shows that women travellers had become a common feature of Roman social life in imperial times. ${ }^{5}$ Not surprisingly, Caecina's motion was defeated.

In the speeches reported by Tacitus the issue whether men travelling into foreign countries for their official duties should be accompanied by their wives is discussed from a restricted male perspective that takes into account only what is more advantageous for men. But if women had been admitted to the Senate and taken part in the discussion of matters that were important also for the female members of the society, what arguments would they have put forward? How would they have described from their point of view their own personal experience of accompanying the male members of their family on their travels? Since the topic of women travellers in the Roman empire is too broad to be discussed within the limits of a short article, the focus will be only on the negative impact that travelling may have had on Roman women. If, as Caecina

4 A.J. Marshall, 'Tacitus and the governor's lady: A note on Annals iii.33-4', Greece \& Rome 22.1 (1975), 11-18; A.J. Barrett, 'Aulus Caecina Severus and the military woman', Historia 54 (2005), 301-314 with previous bibliography. See also L. Foubert, 'The impact of women's travels on military imagery in the Julio-Claudian period', in O. Hekster and T. Kaizer, eds., Frontiers in the Roman World. Proceedings of the Ninth Workshop of the International Network Impact of Empire (Durham, 16-19 April 2009) (Leiden 2011), 349-361. The senatorial debate as reported by Tacitus is also analysed by L. Foubert, 'The lure of an exotic destination: the politics of women's travel in the early Roman empire', forthcoming, who discusses how women's travel threatened the socio-cultural hierarchy of the Roman upper class: I thank Dr Foubert for kindly giving me a copy of her manuscript.

5 For a list of wives or daughters who accompanied magistrates in the provinces, see M.-T. Raepsaet-Charlier, 'Epouses et familles de magistrates dans les provinces romaines aux deux premiers siècles de l'empire', Historia 31.1 (1982), 56-69. 
argues, women's travels had a negative impact on men, as they disrupted the military and political order created and supervised by the male upper-class, how might travel affect Roman women negatively? What were the real dangers that ancient women might have encountered when travelling? What risks to their physical and moral integrity did they perceive when embarking on a journey? In what follows I will try to shed some light on the dangers (real and perceived) of female mobility in the early Roman empire with a discussion of a selected number of literary and epigraphical references to risky journeys taken by women. Given the wide variety of forms in terms of space, time, and motivations that the term mobility encompasses (individuals may travel within the borders of a single province or move significant distances toward other provinces; they may plan to return home after a short journey or to settle down in a foreign country; they may voluntarily decide to embark on a journey or be compelled to leave home), here, for the purpose of my analysis, I will use the term mobility in a generic sense of movement outside the hometown, regardless of its permanent or temporary status or the motivations behind the journey.

Ancient written texts contain a huge amount of references to the dangers and hardships involved in travel, such as storms, piracy, and brigandage, which could affect either male or female voyagers. The perils of one's journeys were certainly a very exciting trope for the readers of ancient novels and poetry and a topic through which the writers of private letters or funerary inscriptions could demand attention and comfort. Very likely, nobody would have wished to read the monotonous details of a rapid and painless journey. The prevalence of anecdotes on dangerous journeys in Graeco-Roman literature and its narrative use may obscure the realities of ancient travel, which would be much safer and easier for most voyagers. Nevertheless, travel remained daunting and was a cause of anxiety at least in the perception and imagination of the majority.

The analysis of literary and epigraphic evidence specifically for women's mobility in Roman imperial times shows that the main danger travellers might have encountered on a sea-journey was shipwreck. A late fourth-century funerary inscription found at Autun, in Gaul, records the name of Eufronia, who had died in a shipwreck. ${ }^{6}$ Similarly, in an epitaph from Dalmatia, Maximus commemorates his young daughter Revocata, aged 8, who had died in a shipwreck

6 For the dangers of travelling by sea, see also Gambash, this volume. ECO $90=I L C V 1540=$ ICG 5 . 
together with her brother Hilarion, aged $4 \cdot{ }^{7}$ In a funerary inscription found at Rome, Iulius Secundus commemorates his wife Cornelia Tyche and his daughter Iulia Secunda, who probably died in the Iberian sea while sailing toward Spain:

Iam datus est finis vitae im/paussa malorum / vobis quas habet hoc gnatam / matremq sepulcrum / litore Phocaico pelagi vi / examinatas / illic unde Tagus et nobile / flumen Hiberus / forsum ortus vorsum occa/sus fluit alter et alter / stagna sub Oceani Tagus et / Tyrrhenica Hiberus

This is the end of your life, the end of sufferings for you, daughter and mother, who are buried in this grave. You two were exhausted by the violence of the sea on the Phocaean coast where Tagus starts and the famous river Hiberus ends and both flow the one into the Ocean and the other into the Tyrrhenian. ${ }^{8}$

Travel by ship did not necessarily end in death, but, undoubtedly, sea-voyages were fraught with perils. Iulia Maior, for instance, while following her husband Agrippa in his campaign in Asia minor, almost drowned on a night of heavy storms while trying to cross the flooded Scamander on her way to Ilium. ${ }^{9}$ The reality of potentially fatal accidents occurring during sea-journeys is reflected in the number of storms and shipwrecks that are described in the Greek and Latin fictional literature and poetry. In the elegiac poetry of the Augustan age, they became a literary trope that poets often used as a means to discourage their mistress from leaving. In Elegy 1.8.1-2, 5-8, Propertius deplores Cynthia's decision to sail toward Illyria and warns her from the rigours of travel that his mistress may not be able to face:

Tune igitur demens, nec te mea cura moratur?

an tibi sum gelida vilior Illyria?

...

tune audire potes vesani murmura ponti

7 CIL 3. $3107=I L C V$ 436o. Shipwreck may have been the cause of death for Victoria, aged 33, who is defined as tra(n)smarina ("beyond sea, coming from beyond the sea") in an epitaph found at Setif, in Algeria ( $C I L$ 8. $20414=I L C V$ 1476a). The fragmentary text does not allow us to know whether Victoria died at Setif, where she had moved, or during her sea journey to the African town.

8 CLE $436=$ CIL 6. 20674 .

9 Nicolaus of Damascus, Fragmente der Griechischen Historiker, 2 A: 421-2. 
fortis, et in dura nave iacere potes?

tu pedibus teneris positas fulcire pruinas, tu potes insolitas, Cynthia, ferre nives?

Are you then fool? Does not my anguish keep you here? Am I less to you than chilly Illyria?... Can you hear the roar of the furious seas and can you lie down on the hard ship bench? Can you press the hard planks with your tender feet? Cynthia, can you endure the unfamiliar snow?

In Amores 2.11. 9-12, 17-26, Ovid tries to discourage Corinna from her plan to go on a 'tricky voyage' by contrasting the dangerous waters to the safe shore:

quam tibi, me miserum, Zephyros Eurosque timebo et gelidum Borean egelidumque Notum! non illic urbes, non tu mirabere silvas; una est iniusti caerula forma maris. ...

et vobis alii ventorum proelia narrent; quas Scylla infestet, quasve Charybdis aquas; et quibus emineant violenta Ceraunia saxis; quo lateant Syrtes magna minorque sinu. haec alii referant ad vos; quod quisque loquetur, credite! credenti nulla procella nocet. Sero respicitur tellus, ubi fune soluto currit in inmensum panda carina salum; navita sollicitus cum ventos horret iniquos et prope tam letum, quam prope cernit aquam.

So much for you I, poor wretch, will fear Zephyros and Euros and the chilly Boreas and the cold Notum. There you will not marvel at either cities or woods; only the blue form of the cruel sea.... Let others tell you of the battles of the winds; of the waters that Scylla or Charybdis trouble; of the furious Ceraunia that stands out of the rocks; of Syrtes that are hidden in the big and small bay. Let others report it to you; whatever is said to you, believe! If you believe, no storm will harm you. Too late one looks back at the shore, when the ropes are loosed and the curved ship sails over the immense sea; while the worried sailor trembles at the adverse winds and sees clearly the water close as much as the death. 
The journeys planned by the Propertian Cynthia and the Ovidian Corinna are literary representations of travels that may be hypothetical or even dream-like. Nevertheless, the literary and epigraphic record of real sea-voyages shows that they may be fatal. Far from being only literary constructions opportunistically exaggerated by the poets in love, the dangers that a woman might have encountered on a ship were so real as to cause anxiety. In Elegy 2.26.1-4, Propertius projects into a dream his fears for Cynthia' safety during her sea-journey:

Vidi te in somnis fracta, mea vita, carina

Ionio lassas ducere rore manus, et quaecumque in me fueras mentita fateri,

nec iam umore gravis tollere posse comas

In my dreams I saw your boat broken in pieces and you, light of my life, to strike out with weary hands through the Ionian waves, and confess all the lies you have told me, unable to lift your hair weighed down with brine.

The risk of injuries or ill health was certainly higher during travels. In a private letter dated to the second century AD, Aphrodite writes to her sister Taonnophoris that while she was going to Alexandria, her foot was injured by a horse; the injury forced Aphrodite to delay her travel arrangements while her foot was being healed at great expense. ${ }^{10}$ Some women may have fallen ill in a foreign country and have died before being able to return home. In Confessions 9.10-11, Augustine recounts the death of his mother Monica at Ostia. On their way back to Africa from Milan, Augustine and his mother stopped at Ostia to rest after the fatigues of a long journey; five days later, she was prostrated by fever, lost conscience for some time, and died. ${ }^{11}$ Though Monica had originally wanted to be buried with her husband in Africa (a wish that was supported by her other son Navigius who said that he would be happier if she died in her own land rather than abroad), she later accepted to be buried at

$10 \quad B G U$ 13. 2350; R.S. Bagnall and R. Cribiore, Women's Letters from Ancient Egypt (Ann Arbor 2006), 366 .

11 For Monica, see also Tacoma, this volume. A further figure of a mother who died in a foreign country while following her son in his travels is Malthace. In the brief account reported by Flavius Josephus (J. AJ. 17.10.1), it is recorded that Herod the Great's wife fell ill and died in 4 BC in Rome, where she had travelled to accompany her son Archelaus who wanted to plead for his father's throne before Augustus. 
Ostia. ${ }^{12}$ Augustine's account of his mother's death in a foreign country reinforces the image of an exceptionally brave woman traveller but also confirms the perils of the ancient journey either by land or sea. In fact, earlier in the text, Augustine had recounted that Monica's first journey to Italy had not been without dangers, ${ }^{13}$ but she was able to comfort the sailors and assured them of a safe arrival:

iam venerat ad me mater pietate fortis, terra marique me sequens et in periculis omnibus de te secura. nam et per marina discrimina ipsos nautas consolabatur, a quibus rudes abyssi viatores, cum perturbantur, consolari solent, pollicens eis perventionem cum salute, quia hoc ei tu per visum pollicitus eras.

My mother had now come to me, resolute with piety, following me by land and sea and in all perils confiding in you. For in the dangers of sea she comforted even the sailors, by whom the inexperienced passengers, when alarmed, use to be comforted, assuring them of a safe arrival, because you had promised that to her by a vision.

This account enables Augustine to emphasise the superior character of his mother and the assurance of God's presence which has helped Monica to face hardship with courage and to calmly overcome the dangers of the sea. However, for the purposes of this paper, what is more interesting is Augustine's remark that the inexperienced voyagers usually go to the sailors for comfort when alarmed. The portrayal of the helpless and distressed traveller who in the moment of peril seeks moral comfort, suggests that in ancient perception travel was associated with dangers, hardship, and uncertainty.

Similarly, Seneca praises his aunt for her heroic behaviour during a seastorm while she was travelling with her husband:

Carissimum virum amiserat, auunculum nostrum, cui virgo nupserat, in ipsa quidem navigatione; tulit tamen eodem tempore et luctum et metum evictisque tempestatibus corpus eius naufraga evexit.

12 For a discussion of this passage and of the ancient practice of the repatriation of corpses, see R.A. Tybout, 'Dead men walking: the repatriation of mortal remains', in L. de Ligt and L.E. Tacoma, eds., Migration and Mobility in the Early Roman Empire (Leiden 2016), 390-437.

13 Aug. Conf. 6.1. I thank Rens Tacoma for pointing out this reference to me. Augustine does not specify what perils Monica encountered on her journey. 
In the midst of a sea-voyage, she had lost her dearest husband, to whom she got married when she was a maiden; nevertheless, she endured at the same time both grief and fear and overcoming the storm she, though shipwrecked, rescued his body. ${ }^{14}$

In Seneca's words, his aunt certainly showed very brave behaviour or perhaps did simply what was expected from a wife. In the very moment of high risk for her life, his aunt did not look at how she might escape from the wrecked ship but resolved to rescue her husband's body and give him a proper burial. ${ }^{15}$

A woman travelling to a foreign country away from the protective environment of the original family may also risk being killed by her closest relatives. Born to an elite family in Rome, Regilla moved to Greece in 138/9 when she married the politician and rhetorician Herodes Atticus, but when she was eight months pregnant, she died of a kick in her abdomen. Her husband was brought to trial in Rome on the charge of murder by Regilla's brother, but with the intercession of the emperor Marcus Aurelius, Herodes was exonerated and only his freedman Alcimedon was declared guilty. In her study of the murder of Regilla, Sarah B. Pomeroy states that "If Regilla had married a Roman, or at least if she had remained in Rome, her brother and other kinsmen and friends, and perhaps even Marcus Aurelius and Faustina, would have monitored her relationship with Herodes."16 I have argued in another article that a woman whose marriage was monitored by her kinsmen was not necessarily protected from a violent husband. ${ }^{17}$ However, Pomeroy's observation that "Regilla's isolation in Greece gave Herodes a de facto power over her"18 poignantly emphasises the high risks that travelling away from the protective environment of home may have for a woman.

Textual evidence attests to other types of perils that ancient travellers might have faced in their journey: attacks by pirates and bandits if travelling respectively by ship and on land..$^{19}$ The inclusion in the Digest of piracy and brigandage among common natural disasters affecting loans (along with the deaths

\footnotetext{
14 Sen. Cons. ad Helv. 19.4.

15 Sen. Cons. ad Helv. 19.5, 7.

16 S.B. Pomeroy, The Murder of Regilla: A Case of Domestic Violence in Antiquity (Cambridge, Mass. and London 2007), 121.

17 M. Carucci, 'Domestic violence in the Roman imperial society: giving voice to the abused women', forthcoming.

18 Pomeroy 2007, op. cit. (n. 16), 121.

19 B.D. Shaw, 'Bandits in the Roman Empire', Past \& Present 105 (1984), 3-52; L.H. Blumell, 'Beware of bandits! Banditry and land travel in the Roman Empire', Journeys 8 (2007), 1-20.
} 
of slaves, fires, shipwrecks, and slaves running away) ${ }^{20}$ and among common misfortunes (such as sickness, sea-storms, and winter weather) ${ }^{21}$ is an indication of their ubiquity and their occurrence during ancient travel, though Roman authors boasted of their eradication thanks to the pax Romana in the empire. Attacks by bandits also were listed as an example of common causes of death along with old age and sickness. ${ }^{22}$ The formulaic expression interfecta/ us a latronibus ("killed by bandits") that appears on a number of tombstones throughout the empire suggests that death due to bandits was a very frequent occurrence ${ }^{23}$ and a danger that may have affected women travellers, too. A badly preserved tombstone found in ancient Dacia was erected by the parents of a beloved daughter who had been killed by bandits. ${ }^{24}$ In a more detailed funerary inscription from Spalato, Iulius Restutus and Statia Pudentilla commemorate their infelicissima daughter Iulia Restuta who has been killed causa ornamentorum ("because of her jewellery"). ${ }^{25}$ The risk of attracting unwanted attention from bandits through the display of jewellery is also mentioned in a private letter dated to 296, in which Paniskos asks his wife Ploutegenia to visit him in Koptos:

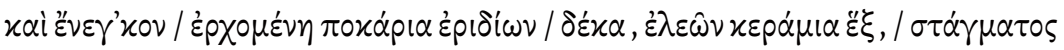

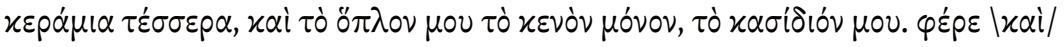

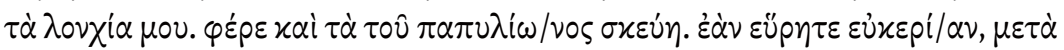

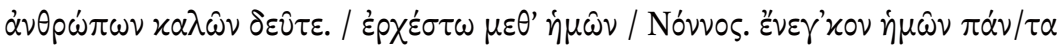

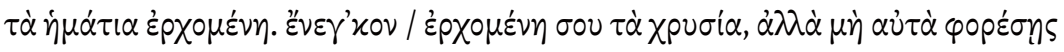
$\dot{\varepsilon} \nu \tau \hat{\omega} \pi \lambda o^{\prime} \omega$.

And when you come, bring ten fleeces of wool, six jars of olives, four jars of honeyed wine, and my shield - only the new one - and my helmet. Bring also my lances. Bring also the fittings of the tent. If you find an opportunity, come here with good men. Let Nonnos come with you. Bring

\footnotetext{
$20 \quad$ Dig. 13.6.18.pr.

$21 \quad$ Dig. 27.1.13.7.

22 Dig.13.6.5.4.

23 See, for instance, CIL 2. 1389, 2968, 3479 (Hispania); CIL 3. 1559, 1579 (Dacia); CIL 3. 2544, 8830 (Dalmatia); CIL 6. 234, 20307a (Rome); CIL 13. 259, 2282, 2667, 3689, 6429 (Germania). References to banditry in the Roman imperial times also occur in literary texts, such as the novel Leucippe and Clitophon by Achilles Tatius (5.7) and in the Metamorphoses by Apuleius $(1.7,15,23 ; 3.28 ; 4.6-22 ; 7.4,12,13 ; 8.15,17-18)$. See also Joh. Chrys. De virg. 24.2.

24 CIL 3.1585.

25 CIL 3. 2399.
} 
all our clothes with you when you come. Bring your gold ornaments with you on the trip, but do not wear them on the boat. ${ }^{26}$

This letter seems to suggest that a woman may be safe on travel, if she is accompanied by good and trustworthy men and does not openly display her jewellery on the way.

A small number of epitaphs collected in the Carmina Latina Epigraphica lament the fatal destiny of some women who died during their journeys, but the cause of their death is not mentioned. Antonia from Mauretania, piissima, dulcissima, rarissima, castissima and amantissima wife of the infelicissimus Titus Claudius Speratus, as it is recorded in the praescriptum, died in Italy while she was accompanying her husband: "The Italic land snatched me away with cruel death, while constantly assisting and serving my husband."27 A further epitaph found at Byzacium, in Africa, records the death of Urbanilla at Carthage while going back home with her husband Lucius:

Urbanilla mihi coniunx verecundia plena hic sita est / Romae comes negotiorum socia parsimonio fulta / bene gestis omnibus cum in patria mecum rediret / au miseram Carthago mihi eripuit sociam / nulla spes vivendi mihi sine coniuge tali / illa domum servare meam illa et consilio iuvare / luce privata misera qu(i)escit in marmore clusa / Lucius ego coniunx hic te marmore texi / (h)anc nobis sorted dedit fatu $(\mathrm{m})$ cum luci daremur

Urbanilla my wife in her full modesty lies here. In Rome she was my supportive partner and associate in business. While she was going back home after a good business had been made, ah Carthago snatched my wretched companion away from me. No hope for me to live without such a wife: she looked after my house and assisted me with her advice. Deprived of light, the wretched woman rests inside a stone. I Lucius your husband buried you in this stone. We were given this fate when we were born. ${ }^{28}$

26 P. Mich. 2. 214; translation adapted from J. Rowlandson, ed., Women and Society in Greek and Roman Egypt: A Sourcebook (Cambridge 1998), 148. This document, which was found in the Fayum, is part of a group of letters exchanged between Paniskos and Ploutogenia.

27 CIL 6. 12056 = CLE 1026: Itala me rapuit crudelifunere tellus, / dum foveo assidua sedulitate virum. M. Arena and I. Bitto, 'Il motivo della morte in terra straniera nei CLE bücheleriani', in A. Akerraz, P. Ruggeri, A.Siraj, and C.Vismara, eds., L'Africa romana XVI, Rabat 2004 (Roma 2006), 1036.

$28 \quad C I L$ 8.152 = CLE 516; Arena and Bitto 2006, op. cit. (n. 27), 1037. 
We may suppose that Lucius was a merchant or involved in some business that he carried on together with his wife; on one of their business trips, Urbanilla died in circumstances that are not mentioned in the carmen. A short epitaph found in Ferentillum, in Etruria, mentions Chreste, a wet-nurse who died while accompanying the dedicators of her tumulus from Libya:

Chreste nutric[i fecimus] / hunc tum[ulum] / occidit haec Liby[ae terrae] / nos grandis a[b ora] / per freta per terr[as sedula] / dum sequ[itur] / corpus habet tellu[s et condita] / membra sed illinc.

We have made for Chreste our wet-nurse this barrow. She died on the wide Libyan shores while she was diligently following us by land and sea. The land has her body and pale limbs, but on that side. ${ }^{29}$

The poem ends with the motif of the individual buried in a foreign country that frequently occurs in funerary inscriptions. ${ }^{30}$

\section{Gendered Travel Risks}

The analysis of literary and epigraphical evidence highlights the most common dangers that ancient Roman women might have encountered in their travels. Nevertheless, the ancient record leaves us with the impression that there was no specifically gendered travel risk. Shipwreck, banditry, murder, and illness are the types of dangers that may have affected everyone on a journey in the Roman empire, regardless of their social status, age, provenance, or gender. What seem more specifically related to gender are rather the conditions of and reasons for travel. ${ }^{31}$

Travel was certainly more difficult and risky for a woman who was pregnant or accompanied by small children. Tacitus recounts that Zenobia was pregnant when she was forced to flee along with her husband Rhadamistus after his failed attempt at invading Armenia in AD 55:

Sed coniunx gravida primam utcumque fugam ob metum hostilem et mariti caritatem toleravit; post festinatione continua, ubi quati uterus

29 CLE 1845 = CIL 11.4991; Arena and Bitto 2006, op. cit. (n. 27), 1040.

30 Tybout 2016, op. cit. (n. 12).

31 For a discussion of the nature of female mobility specifically in Roman Egypt, see Foubert 2016, op. cit. (n. 2 ). 
et viscera vibrantur, orare ut morte honesta contumeliis captivitatis eximeretur.

But his wife, who was pregnant, endured in one way or the other the first part of the flight out of fear of the enemy and love for her husband; after a while, when she felt as if her womb and viscera were shaken by the continuous speed, she implored to be rescued from the shame of captivity by an honourable death. ${ }^{32}$

Urged by the intensity of his love, Rhadamistus agreed to listen to her prayers: he stabbed his wife and consigned her to the nearby river. While he hurried to his native kingdom of Iberia, Zenobia was noticed by some shepherds in a quiet backwater, still breathing and showing signs of life; she was then carried to the city of Artaxata, whence she was conducted to the King of Armenia, Tiridates, who received her kindly and treated her as a royal person. ${ }^{33}$

Iulia Maior probably gave birth to Agrippina Maior and perhaps also to Iulia Minor during her husband Agrippa's campaign in Asia minor; she was at Aquileia when she delivered a child fathered by Tiberius. ${ }^{34}$ Agrippina Maior gave birth to Agrippina Minor and Livilla while travelling with Germanicus; she also gave birth to her last daughter Iulia at Lesbos. ${ }^{35}$ In Tacitus' narrative, Agrippina Maior is portrayed as an active 'travelling wife' who accompanied her husband abroad during his military campaigns in Germania (AD 14) and in the east (AD 18). Travelling with her husband on several of his journeys in the provinces, however, proved to be very difficult and risky for Agrippina as a woman and as wife of a commander. When a mutiny broke out among the German legions, Agrippina had to flee together with her two-year-old son Caligula and a throng of upper-class women, wives of Germanicus' friends, who Tacitus describes as weeping round her. ${ }^{36}$ When Germanicus died in Antioch in 19 AD, Agrippina sailed back to Rome. In a few lines Tacitus portrays this young woman of the highest nobility who was usually praised for her splendid marriage, departing together with her little children and the ashes of her husband

32 Tac. Ann. 12.51.

33 As Tacitus does not make any further mention of the child that Zenobia was carrying, we may conclude that the difficulties of the journey and the stab caused a miscarriage. However, Zenobia and her possible child's later life is not recorded in any ancient textual source.

35 Tac. Ann. 2.54.1.

36 Tac. Ann. 1.40.1. 
while worn out with grief and physically ill: "uncertain of her vengeance, apprehensive for herself, and at fortune's mercy by reason of the ill-starred fruitfulness of her marriage." ${ }^{37}$ Agrippina's return to Rome was not easy, either. Tacitus reports that on her way back to Italy, her ship was met by a squadron commanded by Piso ${ }^{38}$ that was skirting the coast of Lycia and Pamphilia. On each side the hostility was such that at first they prepared for action: then, owing to their mutual fears, the affair went no further than high words. ${ }^{39}$

In a private letter dated to the second century AD, Eutycheis writes to her mother Ametrion that her plan to visit her in Oxyrhynchus has been delayed by the lack of any suitable means of transport. ${ }^{40}$ For some unspecified reason, the camel drivers refused to make the trip; next she planned to travel by boat from Antinoopolis but could not find any boat available for that trip; she decided then to stay at Antinoopolis until a suitable vessel appeared and she could sail down. In the meantime Eutycheis instructed her mother to pay the men who delivered this letter to her. It is not clear how these men were able to travel to Oxyrhynchus. Was Eutycheis refused as a passenger either by camel or boat because of her gender? Or were there disturbances and fights in the region that made travelling more difficult for a woman?

The very brief references to women's journeys in both the epigraphical and literary record are undoubtedly influenced by the gendered ideologies of its male authors. What is missing is a sense of women's agency in their travels. Did Roman women want to travel? Were they happy to accompany their husbands in their military or business travels? What risks did they perceive in association with travel? What were the effects of their perceived travel risks? What strategies did they use to minimise risks? Written accounts of travels by Roman women would have certainly helped us answer those questions and could have provided an alternate view to male-authored narrative. Unfortunately, the corpus of literary works from the early empire includes only a very few

37 Tac. Ann. 2.75.1: incerta ultionis, anxia sui et infelici fecunditate fortunae totiens obnoxia.

38 Gnaeus Calpurnius Piso was appointed by Tiberius as governor of Syria in AD 17, apparently with secret instructions to thwart and control Germanicus, to whom the Eastern provinces had been assigned.

$40 \quad$ P. Oxy. 14. 1773; Bagnall and Cribiore 20o6, op. cit. (n. 10), 371-372. The papyrus was found at Antinoopolis. 
records written by women about their travels. ${ }^{41}$ In Elegy 3.14, Sulpicia ${ }^{42}$ mentions a possible journey to the country where her uncle Messalla is planning to celebrate her birthday, but the visit appeared later to have been cancelled (Elegy 3.15). During her tour to Egypt in the retinue of the emperor Hadrian and his wife, Terentia ${ }^{43}$ left record of her visit in a poem commemorating her deceased brother which was found inscribed on the surface of a pyramid near Memphis. However, it was only in the late eighteenth century that European women began to publish more comprehensive accounts of their travels in everincreasing numbers. Their writings show unmistakably how gender affects the way women experience and portray travel. ${ }^{44}$ Roman female-authored travelogue would also have given us a deeper glimpse into Roman women's experience of and approach to the perils of travel.

\section{$5 \quad$ Conclusions}

As mentioned at the beginning of this article, ancient ideology saw a close connection between women and domesticity. The idea that the natural place for women and femininity was to be found within the domestic world of house and family is expressed in a number of Roman writings. For example, in a funerary epitaph from Rome, Amymone, wife of Marcus, is praised for being lanifica, pia, pudica, frugi, casta, and domiseda ("a woolworker, dutiful, modest, temperate, chaste, and one who stays at home"). ${ }^{45}$ Another funerary inscription from the African town of Mactar commemorates a wife and mother nihil potius cupiens quam ut sua gauderet domus ("who desired nothing more than to rejoice her house"). ${ }^{46}$ In the male ideology, being away from the male-controlled domestic sphere could have exposed a woman to the danger of moral corruption. In Elegy 1.11, Propertius fears that Cynthia's journey to Baiae in the Bay of Naples may distract his mistress from her love for the poet, since the town was notorious

41 For a discussion of the literary and learning activities of ancient Roman women, see E.A. Hemelrijk, Matrona Docta. Educated Women in the Roman Elite from Cornelia to Julia Domna (London and New York 1999).

42 Hemelrijk 1999, op. cit. (n. 41), 148-154. Originally included in the Corpus Tibullianum, Sulpicia's poems were attributed to Tibullus, but this view has been challenged by more recent scholarship.

43 Hemelrijk 1999, op. cit. (n. 41), 164-167.

44 See contributions in K. Siegel, ed., Gender, Genre, and Identity in Women's Travel Writing (New York 2004).

45 CIL 6. 11602.

$46 \quad C I L$ 8.647. 
for licentious behaviour, ${ }^{47}$ while he is happy when Cynthia goes to remote places where no young man can seduce her. ${ }^{48}$ However, as Caecina claims in his speech to the Senate, even in the highly masculine military communities, women would have found an opportunity for intrigues and corrupt behaviour.

In his analysis of female mobility in the Roman West, Greg Woolf makes use of the concept of "social caging" to which ancient women were subject, to support his two main arguments: Roman women's opportunities for moving out of the communities in which they had been born, were very limited and, when they did travel, it was to accompany a male member of their family or their owner, if slaves. ${ }^{49}$ The textual evidence discussed above seems to partly support Woolf's second argument: when women travelled, they did so as wives (Seneca's aunt, Regilla, Antonia, Urbanilla, Zenobia), sisters (Septimius Severus' sister, see below), mothers (Monica), or slaves of a man (perhaps the wet-nurse Chreste). Roman women may also have travelled in the company of (male) servants or hired protectors. As Tacitus suggests in his description of the mutiny of the German legions that forced Agrippina to flee the fort, a centurion or a soldier for protection was part of the customary retinue that accompanied high-status women. ${ }^{50}$ The rhetoric of safety and morality that seems so intimately connected to women's mobility is still embedded in contemporary discourse on solitary women travellers. ${ }^{51} \mathrm{~A}$ woman who embarks on a journey without being escorted by a husband or another appropriate male companion is very likely to be perceived as making herself vulnerable to harassment and other male attacks that put at risk not only her safety but also her morality.

Nevertheless, for some journeys, women may have travelled without any male relative as an escort. In a second- or third-century private letter found in the Arsinoite nome, Thermouthas and Valeria write about their hope to sail downriver to their brother Apollinarios along with Demetrous and her (sc. Demetrous') mother, once Herois has given birth. ${ }^{52}$ In a funerary epigram found in Klaudioupolis, Longinus commemorates his wife Chrysopolis, an

47 Ov. Ars 1.255; Sen. Ep. 51.3. For a different experience of a woman's sojourn in Campania, see Plin. Ep. 6.4. His wife Calpurnia moved temporarily to the Bay of Naples to recover from her illness, while Pliny stayed at Rome to carry on his political affairs.

48 Prop. 2.19.

49 Woolf 2013, op. cit. (n. 2).

$50 \quad$ Tac. Ann. 1.41.

51 K. Siegel, 'Women's travel and the rhetoric of peril: it is suicide to be abroad', in idem 2004, op. cit. (n. 44), 55-72.

$5^{2} \quad B G U$ 1. 261; Bagnall and Cribiore 2006, op. cit. (n. 10), 189-190. The kind of relationships between the women mentioned in the letter are not clear. 
actress who died from fever abroad, while her husband remained at home. ${ }^{53}$ These examples warn us against the easy assumption that Roman women were necessarily accompanying a male member of their family when there is no mention of that. For example, Cornelia Tyche and her daughter Iulia Secunda, Aphrodite, Iulia Restuta, and Eutycheis do not seem to have travelled with any of their male relatives. ${ }^{54}$

The other argument discussed by Woolf, that particular social configurations of social power limited female mobility, seems not to be applicable to all types of ancient mobility, since it is restricted to specific forms of migration, such as military service, manual labour in the larger cities, and commercial activities. In these types of migration, clearly male migrants tended to outnumber women. If, by contrast, we use the term mobility in a wider sense encompassing all forms of moves, we may argue that female mobility was a much wider phenomenon. Furthermore, since Roman women were portrayed in light of social norms and ideals that associated them with home (as especially evident in funerary inscriptions), it could be argued that the lack of mention of travel in the textual references to women does not necessarily mean that they did not embark on any journey during their lifetime.

As ancient evidence shows, the Roman male ideal of the woman as domiseda was not always reflected in the practice of everyday life: a man embarking on a journey for any reason (e.g. political activities, military service, or commercial affairs) often was accompanied by female members of his family as part of the domestic functions that they were expected to perform in their role as good mothers, sisters, wives, or daughters. However, this dominant male ideology with regard to female conduct often also exposed ancient women to risks. Urbanilla died while accompanying her husband in his commercial affairs; Chreste died and was buried in a foreign country; similarly Monica died on her journey back to Africa, while supporting her son Augustine's decision to return home after his travels in Italy; ${ }^{55}$ Ploutogenia was asked to embark on a dangerous journey to join her husband; Agrippina Maior and Zenobia had to follow their husband in their political and military activities in troubled areas. Sometimes the hardships that women suffered travelling for men were more emotional than physical. Septimius Severus' sister came to Rome from Leptis to meet her brother, but she was hurriedly sent back home because her

SGO 09/09/o7; Tacoma and Tybout 2016, op. cit. (n. 2), 362. Chrysopolis may have travelled with a troop of actors.

54 More examples are mentioned by Foubert 2016, op. cit. (n. 2), 362.

55 It was Augustine who wished to return home after his travels in Italy, that was not his mother's own decision. 
inability to speak Latin embarrassed the emperor. ${ }^{56}$ The male-authored text, however, does not reflect on the feelings of Severus' sister: was she, too, embarrassed or was she ashamed of her brother's manners? The brief mention about the number of gifts that Severus gave to his sister before sending her home seems to suggest a feeling of guilt on the part of the emperor.

Caecina did not allow his wife to accompany him in the 40 campaigns that he had served in several provinces, ${ }^{57}$ because the senator regarded women as lacking physical or mental power to face the hardships involved in travel. However, in spite of Caecina's argument, textual evidence for female mobility in the Roman empire shows that women were capable of embarking on a journey with its all difficulties and uncertainties while still keeping their morality and gendered social identity intact.

Cardiff, November 2015

$56 \quad$ HA Sept. Sev. 1.15 .

57 In Caecina's scanty reference to his unnamed wife, it seems that this woman, who had borne her husband six children, had never left Italy. 


\title{
The linouphoi of P. Giss. 40 II Revisited Applying the Sociological Concept of Ethnic Colonies to Alexandria's Linen-Weavers
}

\author{
Elena Koestner
}

\section{1 \\ Introduction}

Mobility has a large impact on many sociological factors within a community and varies between different regions depending on both formal policies and responses to it in different societies. Migration and integration can be seen as vital characteristics of society in general. Migrants leave their home country voluntarily or are compelled to move because of economic, religious, or other individual reasons. When they reach their destination country, one possibility for them is to settle down; however, there is a chance that they might not become integrated. Hence, integration is a dynamic, long-lasting and differentiated process of assimilation. Integration as well as migration can be regarded as essential features of the Roman Empire, too, as Horden and Purcell argued. ${ }^{1}$ Verboven added in his paper of the ninth workshop of the international network Impact of Empire that "ethnic groups and civic communities were bound together in a continuous exchange of outsiders frequenting and settling in each other's communities, spreading news and establishing links between distant places."2 This process is based on reciprocity, but challenges may occur, too.

In this paper this topic shall be analysed on the basis of Alexandria's linenweavers mentioned in P. Giss. $40 \mathrm{II}$ (215 AD). After a riot in Alexandria, in which

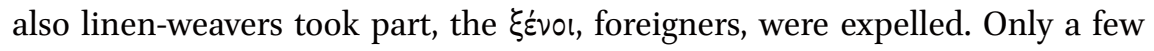
occupational groups were not expelled: the Alexandrian $\lambda$ เvov oi $_{\text {w were allowed }}$ to stay in town, but apparently not the Egyptian workers. ${ }^{3}$ First of all, the internal relations of the linen-weavers and particularly the distinction between

1 P. Horden and N. Purcell, The Corrupting Sea. A Study of Mediterranean History (Oxford 2000), 4 .

2 K. Verboven, 'Resident aliens and translocal merchant collegia in the Roman Empire', in O. Hekster and T. Kaizer, eds., Frontiers in the Roman Empire. Proceedings of the Ninth Workshop of the International Network Impact of Empire (Leiden and Boston 2011), 335.

3 P. Giss. 40 II tells that all migrants will be expelled from Alexandria (l. 16-17). But only the

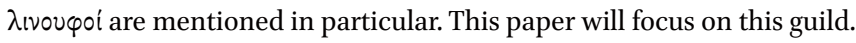


Alexandrians and 'genuine Egyptians' (l. 27) will be of interest. To analyse this, I want to try out the concept of ethnic colonies which was established by the German sociologist Friedrich Heckmann in the 199os. ${ }^{4}$ My assumption is that Egyptian linen-weavers, who had already settled down in Alexandria, served as an ethnic colony for Egyptian workers, who only just arrived. According to our source material it is not possible to state clearly where the migrants came from who settled down in Alexandria. It can be assumed that Alexandria's inhabitants perceived the newcomers as $\xi \xi \dot{v} 0 \mathrm{o}$ and as 'others'. As Goudriaan argued, this discrimination might be regarded as a fundamental process, as a universal trait of human nature. ${ }^{5}$ Hence, these newcomers are called Egyptian migrants or Egyptian linen-weavers in this paper. As a second key topic, the role of the linen-weavers as guild and their networking with other textile guilds in Alexandria will be stressed. Thirdly, one may assume that the term $\lambda$ ivov poi not only labelled linen-weavers, but also all unwanted persons from Alexandria, who were meant to be expelled. This may be regarded as a strategy of the $\pi \dot{0} \lambda ı \varsigma^{-}$ administration to settle conflicts.

2

\section{Alexandria's $\lambda$ เvov५oi and the Expulsion of the Egyptian Workers Mentioned in P. Giss. $40 \mathrm{II}$}

The second text of P. Giss. 40, which deals with the expulsion of Egyptians from Alexandria, is assumed to be an excerpt of an edict made by Caracalla in 215 AD. ${ }^{6}$ More than likely Caracalla stayed in Alexandria while passing this edict, because of the use of $\dot{\varepsilon} \nu \theta \dot{\alpha} \delta \varepsilon$ (l. 26) and the reference to the festivities in honour of Sarapis $(1.20-22){ }^{7}$

4 F. Heckmann, Ghettos oder ethnische Kolonie? Entwicklungschancen von Stadtteilen mit hohem Zuwandereranteil (Bonn 1998), 29.

5 K. Goudriaan, 'Ethnical strategies in Graeco-Roman Egypt', in P. Bilde et al., eds., Ethnicity in Hellenistic Egypt (Århus 1992), 75.

6 A. Łukaszewicz, 'Some Berlin papyri reconsidered', Zeitschrift für Papyrologie und Epigraphik 82 (1990), 130; P.A. Kuhlmann, Die Gießener literarischen Papyri und die Caracalla-Erlasse. Edition, Übersetzung, Kommentar (Gießen 1994), 246-255; C.D. 77.3.3; HA Carac. 3.1; Dig. 50.2.3.1; Cod.Just. 10.61 (59); P. Oxy. 36.2755; W. Chr. $22=$ Sel. Pap. 2. 215. For the assumption that there is not enough evidence for an edict written by Caracalla, see H. Wolff, Die Constitutio Antoniniana und Papyrus Gissensis 40 I (Köln 1976), 131-134; W. Williams, 'Caracalla and the authorship of imperial edicts and epistles', Latomus 38 (1979), 81-83.

7 Kuhlmann 1994, op. cit. (n. 6), 247; A. Harker, Loyalty and Dissidence in Roman Egypt. The Case of the Acta Alexandrinorum (Cambridge 2008), 133. 


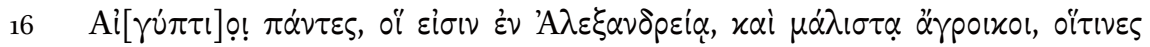
$\pi \varepsilon \dot{\varphi} \varphi \varepsilon \cup[\gamma \alpha \nu]$

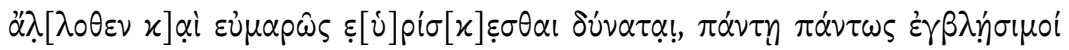

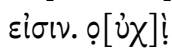

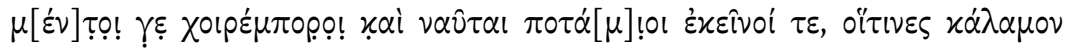
$\pi$ pòs $\tau$ tò

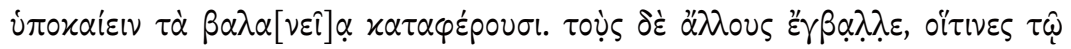
$\pi \lambda \dot{\eta} \theta \varepsilon[\mathrm{l}] \tau \hat{\omega}$

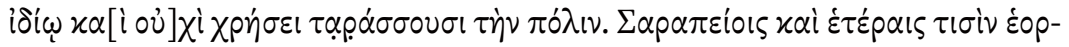

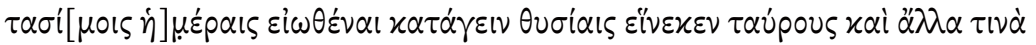

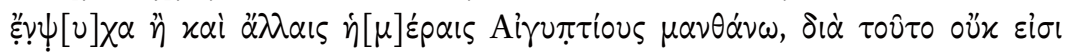
$x \omega \lambda \nu \tau \varepsilon_{\text {çol. }}$

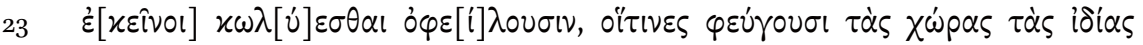
iv $\alpha \mu \dot{\eta}$

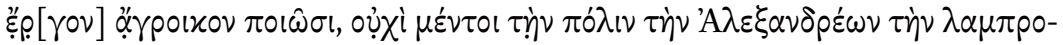

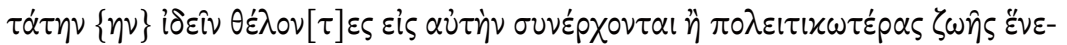

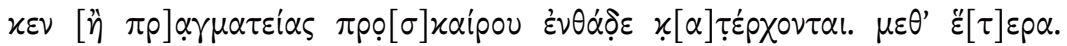
$\varepsilon \dot{\pi} \tau \varepsilon \varepsilon เ \nu \omega \dot{\omega} \sigma \kappa \varepsilon-$

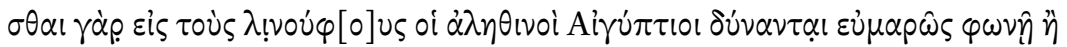

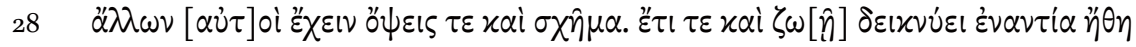

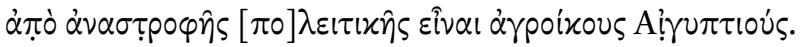

All Egyptians in Alexandria, especially rural peasants, who have fled hither from other parts of Egypt and are easily recognizable, in every possible way must be driven from the city. However, dealers in swine, river boatmen, and those persons who bring down reeds for heating the baths are exempt. Expel the others who by mere numbers keep disturbing the peace to no good purpose. I understand that Egyptians are in the habit of bringing down sacrificial bulls and other livestock at the festival of Sarapis, on certain other festival days, and also at other times. For such visits they must not be prevented. Those persons who leave their homes to avoid work in the fields must be prevented from entering the city, but not those who come down from a desire to see the most famous city of Alexandria or for the sake of a more cultured life or for incidental business obligations. For genuine Egyptians can be recognized easily among the linen weavers by their different dialect, appearance, and dress. Moreover, their way of living and their customs reveal them as country peasants. ${ }^{8}$

8 P. Giss. 40 II, l. 16-29; A.C. Johnson, P.R. Coleman-Norton and F.C. Bourne, Ancient Statutes. A Translation with Introduction, Commentary, Glossary, and Index (Austin 1961), 277; Kuhlmann 
The text tells about an expulsion of indigenous Egyptians living in Alexandria because of their numerous, but presumably useless presence which allegedly led to riots in Alexandria (1. 19-20). However, a few exceptions were mentioned, too: pig traders, inland sailors, and cane-deliverers for the baths (1. 18-19). According to Kuhlmann, these workers made sure that the Greeks and Romans living in Alexandria could keep up their life style. ${ }^{9}$ Moreover, visitors of the festivities in honour of Sarapis and business men were not expelled either (1. 20-22; 24-26).

In order to expel the unwanted Egyptians coming from the $\chi \omega \dot{\omega} \rho \alpha$, they had to be identified and distinguished from Alexandria's inhabitants. Buraselis dealt more intensively with this part of the papyrus and noticed that it was practical to distinguish them according to their vernacular, life-style and appearance (l. 27) $\cdot{ }^{10}$ Likewise, Moatti stated that "appearance also (clothes, objects, particular signs, behavior, voice ...) was an important way of identifying migrants."11 However, the text shows how arbitrarily and hastily the authorities dealt with the identification of migrants, and it also demonstrates how easily incorrect categorisation could take place. Maybe this procedure and the categories used to distinguish migrants from inhabitants make clear that the $\pi \dot{0} \lambda \lambda_{15}$ administration was not interested in identifying Egyptian linen-weavers. One may assume that the expression $\lambda$ ivov expel almost everybody from Alexandria who was regarded as unwanted and too rebellious.

\section{The Concept of Ethnic Colonies and the Multi-Ethnic Metropolis of Alexandria}

P. Giss. 40 II refers in particular to the linen-weavers and the necessity to distinguish between Alexandrian and Egyptian workers among them. This implies that the working and living conditions of the linen-weavers, in particular, attracted Egyptian migrants coming from the rural areas. In this context I want to try out the concept of ethnic colonies. In sociological literature this term

1994, op. cit. (n. 6), 249; K. Buraselis, 'Zu Caracallas Strafmaßnahmen in Alexandrien (215)', Zeitschrift für Papyrologie und Epigraphik 108 (1995), 185.

$9 \quad$ Kuhlmann 1994, op. cit. (n. 6), 246.

$10 \quad$ Buraselis 1995, op. cit. (n. 8), 167; R. MacMullen, 'Nationalism in Roman Egypt', Aegyptus 1 (1964), 183-184.

11 C. Moatti, 'Translation, migration and communication in the Roman Empire: Three aspects of movements in history', Classical Antiquity 25 (2006), 120. 
means formal and informal structures of ethnic self-organisation of migrants. ${ }^{12}$ Ethnic colonies arise through a voluntary gathering of intra-ethnic relations by migrants on foreign territory. Thereby, forms of economic and socio-cultural organisation as well as family connections coming from the home country will be continued. ${ }^{13}$ In doing so, it was not their intention to create a distinction between their community and the majority of a society. It was closeness to family and friends that they strove for. Additionally, kinship- and chain-migration are crucial, which means that migrants are attracted by personally passed-on information of the destination country from relatives and friends. ${ }^{14}$ Structural precondition for an ethnic colony is a sufficient number of migrants who are in the same situation; additionally, ethnic colonies help the migrants to orientate in the new milieu. ${ }^{15}$ Ethnic colonies thus function as an institutional answer to the migrants' needs. The assumption that the Egyptian linen-weavers, who already lived and worked in Alexandria, served as an ethnic colony for the Egyptian newcomers shall be analysed against the background of Caracalla's edict and the riot of 215 .

A constitutional separation between Alexandria and its $\chi \omega \dot{\omega} \rho \alpha$ existed, as

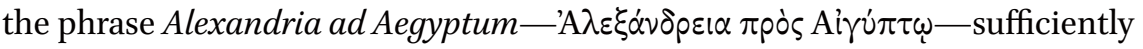
shows. ${ }^{16}$ However, this separation did not play a decisive role in structuring mobility in practice. The differentiation between Alexandrians (originally Macedonians and Greeks) and the Egyptian population was based on a long tradition which was already mentioned by Aristotle. ${ }^{17}$ "Alexandrian citizenship was a hereditary institution, though it was also granted to a small minority of Egyptians."18 Since 31/3о вс Roman law created new categories: Egyptians, Roman, and Greek citizens. ${ }^{19}$ A Roman perspective towards Egypt came

12 Heckmann 1998, op. cit. (n. 4), 29; R. Ceylan, Ethnische Kolonien, Entstehung, Funktion und Wandel am Beispiel türkischer Moscheen und Cafés (Wiesbaden 2006), 50;67.

13 F. Heckmann, Ethnische Minderheiten, Volk und Nation (Stuttgart 1992), 98; Ceylan 2006, op. cit. (n. 12), 51 .

14 Ceylan 2006, op. cit. (n. 12), 53-54.

15 Heckmann 1992, op. cit. (n. 13) 97-98; Ceylan 2006, op. cit. (n. 12), 52-53.

16 SB 5.8328.

17 Arist. Ath. pol. 1329b. The majority of Alexandria's population were Greeks and Macedonians. They got Alexandrian citizenship because of a $\mu \varepsilon \tau \alpha \beta \circ \lambda \dot{\eta} \pi \alpha \tau$ íंos (BGU 6.1213; 6.1250; D. Delia, Alexandrian Citizenship During the Roman Principate. American Classical Studies 23 [Atlanta 1991]).

18 M.S. Venit, 'Alexandria', in C. Riggs, ed., The Oxford Handbook of Roman Egypt (Oxford 2012), 104.

19 My paper takes as a basis the description of Alexandria's population mentioned in K. Vandorpe, 'Identity', in C. Riggs, ed., The Oxford Handbook of Roman Egypt (Oxford 2012), 260-264. 
along: quite often Roman literature alludes to an apparent dependence on the granary that was Egypt. ${ }^{20}$ At the same time the historiographic and literary sources used topoi of refusal and aversion towards Egypt and its population. ${ }^{21}$ The behaviour towards Alexandria is peculiar, because on the one hand the city was praised for its commerce and culture, but on the other hand its inhabitants were described as frivolous, quarrelsome, and violent. ${ }^{22}$ Nevertheless, a citizen body existed which differed from the mass of the Egyptian population. ${ }^{23}$ The differentiation between Egyptians and Alexandrian citizens was not developed by Roman emperors, but they adopted this distinction, which was already established in Ptolemaic times. Ethnicity was used as a way to organise cultural differences. The participants were divided in a 'we' and a 'they'. ${ }^{24}$ Applying Heckmann's concept of ethnic colonies to antiquity, I start from the premise that the marking of boundaries is a universal trait of human experience.

Papyrus texts occasionally provide a glimpse of internal migration, which is also a central theme in P. Giss. $40 \mathrm{II}$ : those Egyptians who had fled from the rural areas to the city were now requested to leave Alexandria. "From the available papyrology documents one can clearly discern the existence in Alexandria of a dense rural population from the villages of Middle Egypt."25 According to Abdel-Ghani, the working opportunities in Alexandria may be regarded as decisive for some of the migrants. ${ }^{26}$ Braunert regards the expulsion of the Egyptian linen-weavers as a measure of the emperor to counteract rural migration

$20 \quad$ C.D. 50.24.6; Lucan. 8.543; 10.54; Flor. 2.13.6o; Plin. Paneg. 31.2; Tac. Ann. 12.43.4; Hist. 1.11; Juv. $15 \cdot 33-38 ; 15 \cdot 75-83$.

21 D. Chr. 11.32; 11.37-39; Philostr. vA 3.32; W.D. Barry, 'Aristocrats, orators, and the "mob": Dio Chrysostom and the world of the Alexandrians', Historia 42 (1993), 82-103.

22 N. Lewis, Life in Egypt under Roman Rule (Oxford 1983), 196; B. Isaac, The Invention of Racism in Classical Antiquity (Princeton and Oxford 2004), 352-370; A.Z. Bryen, 'Visibility and violence in petitions from Roman Egypt', Greek, Roman, and Byzantine Studies 48 (2008), 181-200; A.Z. Bryen, Violence in Roman Egypt. A Study in Legal Interpretation (Philadelphia 2013), 28-40; denied by R. Meyer, 'Roman attitudes towards Egyptians', The Ancient World 3 (1980), 97-103.

23 J. Rowland and A. Harker, 'Roman Alexandria from the perspective of the papyri', in A. Hirst and M. Silk, eds., Alexandria, Real and Imagined (London 2004), 81-82.

24 Goudriaan 1992, op. cit. (n. 5), 75; Vandorpe 2012, op. cit. (n. 19), 268.

25 M. Abd-el-Ghani, 'Alexandria and Middle Egypt: Some aspects of social and economic contacts under Roman rule', in W.V. Harris and G. Ruffini, eds., Ancient Alexandria between Egypt and Greece (Leiden and Boston 2004), 163.

26 Abd-el-Ghani 2004, op. cit. (n. 25), 163; P. Oxy. 4.744 = Sel. Pap. 1.105; P. Oxy. 1.36; 2.294; $8.1158 ; 8.1160 ; 38.2860 ; 41.2981 ; 41.2983 ; B G U$ 7.1572. 


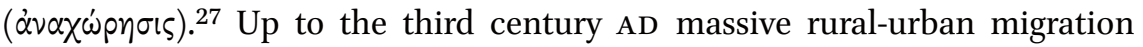
occurred because of an oppressive tax burden. Since the beginning of the second century AD the emperors and prefects tried hard to take countermeasures through decrees and amnesties, but without success. ${ }^{28}$ According to Sünskes Thompson, Caracalla showed with his edict his concerns about the increasing number of people without any possessions and land who overcrowded the cities, such as Alexandria, and who caused lots of problems such as dissatisfaction and riots. ${ }^{29}$

\section{4}

\section{The Situation of the Linen-Weavers in Alexandria}

Dion of Prusa calls Alexandria the greatest commercial centre of the eastern Mediterranean..$^{30}$ Besides the production of papyrus, textile production was one of the most important branches of the economy in Alexandria and it also played a major role for export, especially for luxury clothing. ${ }^{31}$ "Textile production had several specifications that moved through the entire production process, from raw materials to finished goods." ${ }^{32}$ Additionally, well elaborated networks existed between the $\lambda$ ivov oi $^{\prime}$ and other branches of textile production such as fullers, cutters, dyers, sewers whose workshops were located in

27 H. Braunert, Die Binnenwanderung. Studien zur Sozialgeschichte Ägyptens in der Ptolemäer- und Kaiserzeit (Bonn 1964), 164-167; Lewis 1983, op. cit. (n. 22), 202; Kuhlmann 1994, op. cit. (n. 6), 248-249; denied by Williams 1979, op. cit. (n. 6), 86. For further examples see $S B$ 1.4284; P. Flor. 1.6; P. Lond. 3.904 II; $B G U 2.372=S B$ 20.14662; P. Oxy. $2.252=$ W. Chr. 215; P. Oxy. 2.253 .

28 For further examples see P. Lond. 3.904 = W. Chr. 202; sB 6.9526 = P. Col. 6.123; P. Oxy. 47.3364; A. Papathomas, 'Ein neues Reskript der Kaiser Septimius Severus und Caracalla', Zeitschrift für Papyrologie und Epigraphik 131 (2000), 129-134. A petition of a $\sigma \tau p \alpha \tau \eta \gamma o ́ s$ from 207 tells about permanent failures in managing rural-urban-migration ( $s B$ 1.4284; P. Col. 6.123; P. Westminster Coll. 3; P. Flor. 1.6; BGU $2.372=$ W. Chr. 19).

29 J. Sünskes Thompson, Aufstände und Protestaktionen im Imperium Romanum. Die severischen Kaiser im Spannungsfeld innenpolitischer Konflikte (Bonn 1990), 166.

$30 \quad$ D. Chr. 32.36; Str. Geogr. 17.1.13.

31 Lewis 1983, op. cit. (n. 22), 134-135; P. Oxy. 14.1647; 66.4534; 51.3626; 51.3621; BGU 1.24; 3.855; 4.1021; P. Tebt. 385; PSI 3.241; P. Lips. 1.89; P. Bodl. 1.16; P. Oxy. 14.1705 = Sel. Pap. 1.36; P. Strasb. 7.618; $S B$ 14.11575.

32 M. Gibbs, 'Manufacture, trade, and the economy', in C. Riggs, ed., The Oxford Handbook of Roman Egypt (Oxford 2012), 45. A few examples may illustrate this kind of specification for the production of linen: $B G U$ 15.2471; P. Bub. 1.212. 
town, while linen-farmers could be found in the rural areas. ${ }^{33}$ To guarantee the excellent quality of Alexandria's linen-products and the large quantities for export, there had to be a smooth cooperation between these different textile branches. Because of its commercial and strategic location, Alexandria developed into a hub for the linen trade.

According to Braunert, Egyptians from the $\chi \omega \dot{\omega} \rho \alpha$, who were used to work as farmers, found work in Alexandria's linen-workshops. ${ }^{34}$ The motive of earning money in Alexandria is mentioned explicitly. ${ }^{35}$ Several papyri tell us about individuals who migrated to Alexandria and settled down there, but in most of these cases it is not clear where they came from exactly and in which occupations they found work. ${ }^{36}$ "The phenomenon of country-people frequently staying in Alexandria seems to have been so grave at times that it required official reactions and interferences to control." ${ }^{37}$ This explains why there existed the necessity to distinguish between Egyptian and Alexandrian linen-weavers in P. Giss. 40 II (1. 27-29). In the light of this development Alexandria's administration regarded migrants from the $\chi \omega \dot{\omega} \rho \alpha$ as useless for the city. They used xenophobic stereotypes in order to create an atmosphere which suggests a feeling of overpopulation and overcrowding. Hence, the disturbance of the city life-

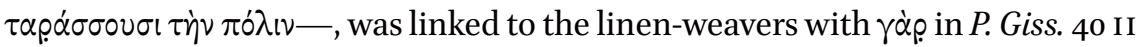
(1. 27). ${ }^{38}$ This phrase suggests that Caracalla took the riot in Alexandria seriously. Maybe this is because he stayed in town at that time. ${ }^{39}$

In the light of all these factors it is highly probable that there is a connection with the expulsion Cassius Dio is writing about:

33 W. Broekaert, 'Occupational associations and monopolies in the Roman economy', in preparation, 13 .

34 Braunert 1964, op. cit. (n. 27), 175; Gibbs 2012, op. cit. (n. 32), 42; P. Oxy. 22.2340.

35 P. Oxy. $3.487(156)=$ M. Chr. 322.

$36 \quad$ P. Oxy. 8.116o; 14.1678; 14.1670; $3.487=$ M. Chr. 322; P. Tebt. 2.418 v; PSI 3.162; P. Merton. 2.83; P. Mich. 3.121; P. Giss. 1.79 IV. Some papyri tell us about middlemen, who looked for workers from the $\chi \omega \dot{\omega} \rho \alpha$ to bring them to Alexandria: P. Oxy. 38.2860; 41.2981. Other texts inform us about journeys to Alexandria because of administrative affairs or of visiting relatives and friends: $P$. Col. 8.216 = SB 5.7661; BGU 7.1680; 7.1572; SB 5.7662 = P. Col. 8.225; PSI 13.1332 =SB 5.7992; P. Oxy. 8.1158; 10.1296; P. Merton. 1.28 .

37 Abd-el-Ghani 2004, op. cit. (n. 25), 168.

$38 \quad$ Buraselis 1995, op. cit. (n. 8), 170 with further remarks.

39 Buraselis 1995, op. cit. (n. 8), 186; A. Łukaszewicz, 'Quelques remarques sur l'expulsion des Aigyptioi d'Alexandrie', in G. Nenci and G. Thür, eds., Symposion 1988. Vorträge zur griechischen und hellenistischen Rechtsgeschichte (Köln 1990), 341-347; Łukaszewicz 1990, op. cit. (n. 6), 129 . 


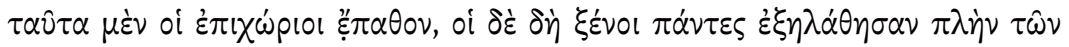

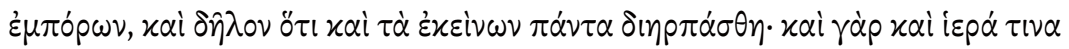

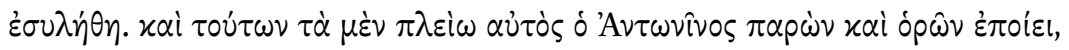

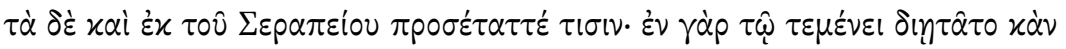

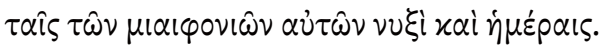

The foreigners were all expelled, except the merchants, and naturally all the property of these was plundered; for even some shrines were despoiled. Antoninus was present at most of this slaughter and pillaging, both looking on and taking a hand, but sometimes he issued orders to others from the temple of Serapis; for he lived in this god's precinct even during the very nights and days of bloodshed. ${ }^{40}$

Kuhlmann and Buraselis convincingly argued that the $\xi \dot{\varepsilon} v o r$ mentioned in

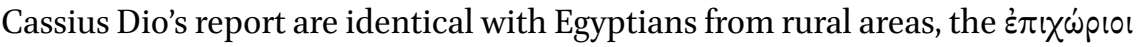
with the Alexandrians. ${ }^{41}$ How can this riot and the following massacre be interpreted in regard to the linen-weavers? In general, Alexandria enjoyed the reputation of being particularly derisive towards Roman emperors. Also Caracalla had this experience; he was among other things verbally attacked because of murdering his brother Geta. Herodian as well as Cassius Dio claimed that revenge was his central motive for the ensuing massacre. ${ }^{42}$ The ancient authors wanted to show the emperor's cruelty and arbitrariness. At the same time, their reports reveal their own prejudices. In fact, it can be assumed that the riot transpired because of Caracalla's stay in Alexandria. This was the chance for

40 C.D. 77(78).23.2 (Cassius Dio, Roman History, ed. E. Cary, Loeb Classical Library, [London 1968]); Hdn. 4.8-9; HA Carac. 6.2-3. The Acta Alexandrinorum-literature does not shed

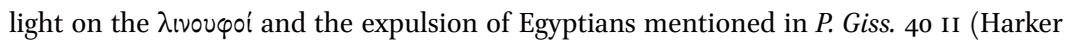
2008, op. cit. (n. 7), 57-58; 133-138).

41 Buraselis 1995, op. cit. (n. 8), 172; 186-187; Kuhlmann 1994, op. cit. (n. 6), 248; denied by Łukaszewicz 1990, op. cit. (n. 6), 131: "It is not sure whether Dio's $\xi \dot{\varepsilon} v 0$ are really to be inter-

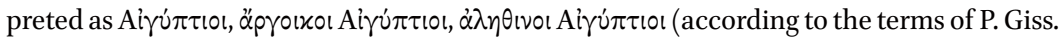
40 II)." Neither Herodian (4.8-9) nor Cassius Dio (77[78].23.1-3) or the Historia Augusta (Carac. 6.2-3) tells about riots, but they all report verbal attacks against Caracalla.

42 F. Kolb, Literarische Beziehungen zwischen Cassius Dio, Herodian und der Historia Augusta (Bonn 1972), 97-111; Sünskes Thompson 1990, op. cit. (n. 29), 34-35; 159-166; D. Baharal, 'Caracalla and Alexander the Great: a reappraisal', in C. Deroux, ed., Studies in Latin Literature and Roman History. Vol. 7 (Bruxelles 1994), 529; A. Bérenger-Badel, 'Caracalla et le massacre des Alexandrins: entre histoire et légende noire', in D. El Kenz, ed., Le massacre, objet d'histoire (Paris 2005), 121-139; Harker 2008, op. cit. (n. 7), 133-134; C.D. 77(78).17.1-4; 77(78).22.1-23.3; Hdn. 4.7.2; 4.8.6-9.8; HA Carac. 6.2-3; P. Oxy. 12.1406; 43.3094. 
the population to address their complaints about fiscal burdens directly to the emperor. After the riot and the massacre Caracalla took steps to re-establish calm and order by separating the town through a wall, building up fortifications, and forbidding spectacles and public messes $\left(\sigma v \sigma \sigma^{i} \tau \iota \alpha\right) .{ }^{43}$ Meetings and communication of the inhabitants were regulated. All these measures served as a more effective way of controlling and reassuring the city and of preventing further riots:

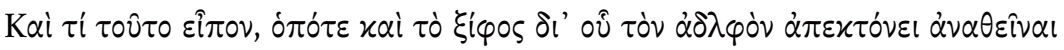

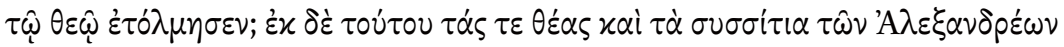

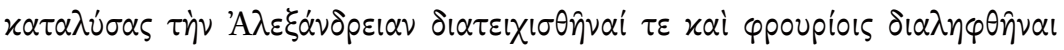

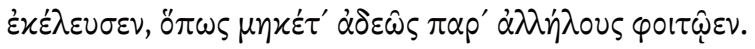

Yet, why do I mention this, when he actually dared to dedicate to the god the sword with which he had slain his brother? Next he abolished the spectacles and the public messes of the Alexandrians and ordered that Alexandria should be divided by a cross-wall and occupied by guards at frequent intervals, in order that the inhabitants might no longer visit one another freely. ${ }^{44}$

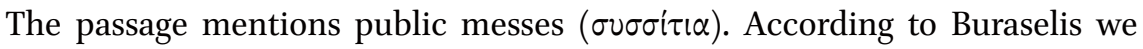
may see here that Caracalla's special attention was targeted on branches of the economy. ${ }^{45}$ Cassius Dio used $\sigma v \sigma \sigma i \tau 1 \alpha$ as a term for symposion or convivium. In this case $\tau \dot{\alpha} \sigma \nu \sigma \sigma i \tau 1 \alpha \tau \hat{\omega} \nu$ 'A $\lambda \varepsilon \xi \alpha \nu \delta \rho \hat{c}^{\prime} \omega \nu$ must refer to collegia, more precisely community meals of Alexandrians and therefore Alexandrian collegia. However, collegia of Egyptians were not mentioned in Cassius Dio's report. Either, both Alexandrian and Egyptian collegia were meant and consequently were involved in the riot, or Cassius Dio's report is not precise. The evidence of other civitates show that collegia of peregrini existed. The case of Lugdunum demonstrates clearly that "local craftsmen and resident foreigners (the consistentes) of a single trade apparently did not join a single association, but

43 Sünskes Thompson 1990, op. cit. (n. 29), 34-35; P. Giss. 40 II; SB 1.4284; P. Oxy. $47 \cdot 3364$.

44 C.D. $77(78) \cdot 23 \cdot 3$.

45 Buraselis 1995, op. cit. (n. 8), 180; for further details see K. Buraselis, 'Eine Notiz zu Augustus, Caracalla und den syssitia in Cassius Dio 54.2.3 und 77(78).23.3', Zeitschrift für Papyrologie und Epigraphik 124 (1999), 300; A. Favuzzi, 'Ancora su Caracalla e i syssitia degli Alessandrini', Zeitschrift für Papyrologie und Epigraphik 121 (1998), 251-256. 
established different collegia." ${ }^{\text {6 }}$ Collegia strengthened the ties between the foreigners because they offered their members social and religious opportunities, and economic benefits. Additionally, they served as a link with other collegia in the same branch. This seems similar to the duties and tasks of an ethnic colony. "Collegiate life revolved around social gatherings for communal eating and drinking." 47

Comparing P. Giss. 40 II with Cassius Dio's text on the linen-weavers, Buraselis notices a special treatment of the Egyptian workers; only these men should be expelled. ${ }^{48}$ This constitutes a massive intervention into the internal structure and freedom of linen-weavers' collegia. Here two aspects are important. First of all, it is possible that also Alexandrian linen-weavers were involved in the riot. Because of the linen-weavers' close cooperation with other branches of textile production, a high degree of organisation existed, and consequently a high potential to mobilise enough people to perform a riot, too. Even though we are not informed about the exact motives of the linen-weavers for their participation in the riot, we may assume that there was a connection to Caracalla's campaign against the Parthians. Because of the preparations for this campaign, it is likely that there was a higher demand for linen-products, for example for soldiers' clothing and equipment. ${ }^{49}$ Thus, there was a higher pressure on the linen-weavers to comply with this much greater demand. It is quite possible that the linen-weavers used Caracalla's visit in Alexandria to call attention to their problems and worries. At the same time, other dissatisfied people used this platform for their protests, too.

Secondly, the categories mentioned in the papyrus to distinguish between Egyptian and Alexandrian linen-weavers are not suitable for a clear differentiation. Clothes and particular signs, that Moatti and Buraselis regarded as suitable for distinguishing migrants, did not work in practice, because these objects could be changed quickly.50 To a Roman outsider or even to an Alexandrian magistrate, it may have been less easy to discriminate between Egyptians and Alexandrians than Caracalla's edict states. ${ }^{51}$ One may assume that a serious interest in creating a useful instrument for distinguishing migrants did not

46 Broekaert, op. cit. (n. 33), 13; P. Oxy. 13.11750; 13.6453; for further details see Verboven 2011, op. cit. (n. 2), 338-348.

Verboven 2011, op. cit. (n. 2), 344; Gibbs 2012, op. cit. (n. 32), 41.

48 Buraselis 1995, op. cit. (n. 8), 182.

49 Buraselis 1995, op. cit. (n. 8), 182-183; BGU 7.1564; 7.1572; I. Eph. $215=$ SEG $4.512=P H I$ 247938 .

$50 \quad$ Buraselis 1995, op. cit. (n. 8), 167; Moatti 2006, op. cit. (n. 11), 120.

51 Rowland and Harker 2004, op. cit. (n. 23), 103. 
exist. The labels $\lambda$ เvovyoi and $\xi \dot{\varepsilon} v 0$ r remained stereotypes which were used to justify the expulsion. Cassius Dio's passage about the prohibition of public messes may be regarded as supplementary information to P. Giss. $40 \mathrm{II}$. The latter indicates that only Egyptian workers were expelled. The term $\lambda$ ivov $\varphi$ oi was used as a stereotype to define people who probably were expelled in order to manage overpopulation and to prevent riots. ${ }^{52}$ According to this classification nearly everybody could have been affected by expulsion.

\section{The Guild of the Alexandrian Linen-Weavers as an Example for the Process of Integration}

Probably, the linen-weavers of Alexandria fought for the improvement of their financial situation. The aspect of payment was not only of interest to the Egyptian workers, but to the Alexandrian weavers, too. In this regard we can find no difference between both. Therefore it is more than likely that both Alexandrian and Egyptian linen-weavers expressed their complaint together in the riot. It is likely, too, that not only linen-weavers came together and went

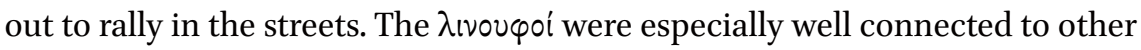
collegia of textile branches and consequently, they could quickly mobilise a huge number of people who were willing to participate in a riot. According to the texts mentioned above, the linen-weavers were associated with riots which threatened public order. In my opinion, their depressed financial situation may be regarded as their basic complaint. In the case of Alexandria, a subversive connotation comes to mind, too, because the riot was directed against Caracalla. As already mentioned, this was the chance for the population to show their dissatisfaction and address their complaints directly to the emperor. ${ }^{53}$ This would have carried much more weight than just complaining to the $\pi \dot{\lambda} \lambda$ ıৎ-administration.

The Alexandrian linen-weavers of the time of Caracalla did not only produce goods for sale on the free market, but also equipment for military campaigns. ${ }^{54}$ They had to work harder to cope with the higher workload. Consequently, the linen-weavers' social status raised their self-confidence, too. One may assume

$5^{2}$ For remarks on the term linen-weavers as a devaluating stereotype, see R. MacMullen, Social Relations 50 BC to $A D 284$ (New Haven and London 1974), 139.

53 Łukaszewicz 1990, op. cit. (n. 6), 131; P. Lond. 3.904.

54 For remarks on the campaigns against the Parthians see C.D. 79(78).1-5; Hdn. 4.10-13; HA Carac. 6.6-7.2; K.-H. Ziegler, Die Beziehungen zwischen Rom und dem Partherreich (Wiesbaden 1964), 133; Sünskes Thompson 1990, op. cit. (n. 29), 66-67. 
that a chronological connection between the beginning of the campaign's preparations, Caracalla's stay in Alexandria, and the riots existed. The linenweavers of Alexandria protested in the streets because of the increasing workload and their precarious financial situation. The reproach of uselessness as

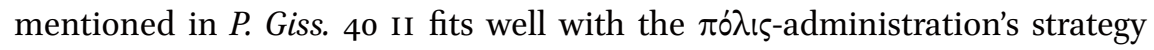
to generate negative emotions against unwanted persons, no matter how far removed from reality this may have been.

Another central aspect is the excessively large number of linen-weavers living and working in Alexandria. A feeling of overpopulation and overcrowding seemingly led to resentment. Because of the linen-weavers' network including other collegia of the textile branch, it was quite easy for them to mobilise enough people willing to participate in a riot. Other dissatisfied inhabitants were ready to follow them, too. A certain amount of people is necessary to perform a riot; a critical mass has to be reached. In the field of game theory, critical mass means that not the whole group must be convinced of an idea; just a certain number of people have to follow. If this threshold is passed and the critical mass is reached, the idea will become effective. This will have applied to the linen-weavers and those who were supporting them, too. At the same time, their number, which was regarded as excessive, was connected to their alleged uselessness. It is quite interesting that a link was made between these two concepts; as a result, the linen-weavers' perceived value for the $\pi \dot{0} \lambda \lambda_{1 \varsigma}$ was diminished. In the case of Alexandria this stereotype certainly did not reflect reality, because an extensive linen-production was located there. The labelling may have functioned as a justification for the expulsion of unwanted Egyptian workers.

And what about the other key topic: can Egyptian linen-weavers who already settled down in Alexandria be regarded as an ethnic colony for migrants from the $\chi \omega \dot{\rho} \rho \alpha$ ? As previously mentioned $P$. Giss. 40 II particularly refers to the linenweavers and the apparent necessity of distinguishing between Alexandrian and Egyptian workers among them. ${ }^{55}$ In my opinion, the branch of the linenweavers will have been especially attractive to Egyptian workers. The concept of ethnic colonies describes the establishment of migrants' relationships within their own ethnic community, their new home country and the continuity of family relations. ${ }^{56}$ Perhaps there existed a linen-weavers' quarter in Alexandria, similar to those we know from Oxyrhynchos, Arsinoe, Karanis,

55 Heckmann 1992, op. cit. (n. 13) 98; Ceylan 2006, op. cit. (n. 12), 51; 53; Braunert 1964, op. cit. (n. 27), 175 .

$5^{6}$ Heckmann 1992, op. cit. (n. 13) 98; Ceylan 2006, op. cit. (n. 12), 51. 
Theadelphia, and Tebtynis. ${ }^{57} \mathrm{~A}$ structural requirement for an ethnic colony is a sufficiently high number of migrants. Because Alexandria's linen-production was of paramount importance for the city and occasionally also for the military sector, workers were always needed. Probably, Egyptians from Alexandria's $\chi \omega \dot{\omega} \rho \alpha$ looked for jobs there. ${ }^{58}$ Financial incentives fuelled this rural-urban migration. Another important point is that the population in Alexandria did not have to pay taxes. Finally, the effect of kinship- and chain-migration must also not be underestimated. ${ }^{59}$ The story of a successful migrant, showing that working as a linen-weaver in Alexandria was an opportunity, might reach his home village and incite friends and relatives to do the same.

To conclude, the linen-weavers mentioned in P. Giss. 40 II shed light on the interweaving of Alexandrians and Egyptians in the multi-ethnic landscape of Alexandria. Ethnic colonies may be regarded as a supportive community for migrants so that they can adapt to a new environment. Similarly, collegia may be

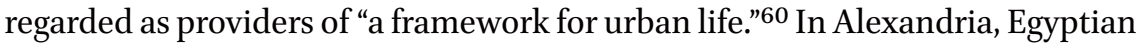
linen-weavers provided support for migrants from the rural areas in terms of job offers, and thus, they provided the basis for them to settle down. They connected the migrants to the formal structures of the $\pi \dot{\lambda} \lambda$ เ५. In these microcommunities they offered the basis for the migrants to increase their social capital. With regard to the expulsion of Egyptians mentioned in P. Giss. 40 II the procedure to distinguish Egyptian from Alexandrian linen-weavers was not a practical one. Distinguishing according to life-style and appearance was not

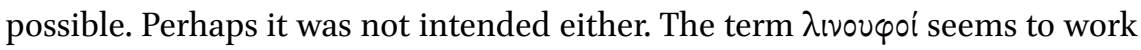
as a label used by the $\pi \dot{0} \lambda \mathrm{i}$-administration to expel all unwanted inhabitants, not only linen-weavers. As shown here, the concept of ethnic colonies may be regarded as a useful approach to gain a glimpse at migration and integration in Alexandria.

Regensburg, November 2015

$57 \quad$ P. Oxy. 14.1634; 1.99; P. Fay. 59; 90; P. Tebt. 2.231; BGU 15.2471; SB 6.9554 2c; P. Mich. 1.123; Gibbs 2012, op. cit. (n. 32), 42. Cf. L.E. Tacoma, 'Migrant quarters at Rome?', in G. de Kleijn and S. Benoist, eds., Integration in Rome and in the Roman World. Proceedings of the Tenth Workshop of the International Network Impact of Empire (Leiden and Boston 2014), 335, denying the existence of migrant quarters in Rome.

58 P. Giss. 1.79 .

59 P. Col. 8.216 = SB 5.7661; BGU 7.1680; SB 5.7662 = P. Col. 8.225; PSI 13.1332 = SB 5.7992; P. Oxy. 8.1158; 10.1296; P. Merton. 1.28 .

6o $\quad$ Verboven 2011, op. cit. (n. 2), 348. 


\title{
Coloni et incolae, vingt ans après ${ }^{1}$ Mobilité et identité sociales et juridiques dans le monde romain occidental
}

\author{
Stéphane Benoist
}

Il m'apparaît nécessaire de rappeler que toute histoire, consciemment ou inconsciemment, s'écrit au temps présent et qu'il est ainsi illusoire de considérer que le contexte de rédaction puisse n'avoir aucune incidence sur la nature des enquêtes historiques que nous menons. ${ }^{2}$ Dans les années 1970-1980, l'essentiel de la réflexion a porté, tant en France que dans le monde anglo-saxon, sur la définition des empires et de l'impérialisme, ce qui induisait un rapport étroit entre histoire contemporaine de la décolonisation et perception du monde romain impérial, l'une et l'autre questions étant étroitement liées en Afrique du Nord romaine. ${ }^{3}$ Il ne viendrait à personne de considérer qu'un long

1 Je tiens à remercier les éditeurs du volume pour leurs fructueuses remarques. Le titre de ce chapitre salue les uicennalia de la parution de l'article d'A. Chastagnol, 'Coloni et incolae. Notes sur les différenciations sociales à l'intérieur des colonies romaines de peuplement dans les provinces de l'Occident ( ${ }^{\text {er }}$ s. av. J.-C.- ${ }^{\text {er }}$ s. ap. J.-C.)', in A. Chastagnol, S. Demougin et C. Lepelley, eds., Splendidissima civitas. Études en hommage à François Jacques (Paris 1996), 13-25 = idem, La Gaule romaine et le droit latin. Recherches sur l'histoire administrative et sur la romanisation de ses habitants. Scripta varia 3. Coll. du Centre d'études romaines et galloromaines 4 (Lyon 1995), 131-141.

2 Une seule référence suffira: les multiples entrées du récent Dictionnaire de l'historien (Paris 2015), notamment celles abordant la question du métier de l'historien et de ses pratiques, 'Historien' (C. Gauvard et J.-Fr. Sirinelli, 371-375), 'Temps', 'Antiquité', 'Périodisation' et 'Durée' (S. Benoist, 694-698, 22-23, 527-529 et 187-188). Et plus directement pour notre présent propos: 'Migrations' (M. Martini, 457-459) et 'Identité(s)' (C. Judde de Larivière, 384-386).

3 À propos des débats concernant l'impérialisme à Rome, partir en premier lieu de P. Veyne, 'Ya-t-il eu un impérialisme romain?', Mélanges de l'École française de Rome. Antiquité 87 (1975), 793-855, puis de deux colloques contemporains, français et américain: L'impérialisme romain. Histoire, idéologie, historiographie, publié en deux livraisons de la revue Ktèma 7 (1982), 141233 et 8 (1983), 111-277; notamment les contributions d'Ed. Frézouls, 'Sur l'historiographie de l'impérialisme romain', 141-162 et C. Nicolet, 'L'Empire romain: espace, temps et politique', 163-173; cf. auparavant la conclusion de ce dernier dans C. Nicolet ed., Rome et la conquête 
quatrième siècle qui nous mène de la mise en place de la tétrarchie au sac de Rome par Alaric, en nous livrant des récits historiques - les épitomés d'Eutrope, d'Aurelius Victor ou du Pseudo-Aurelius Victor -, des biographies impériales avec le de uita principum de l'Histoire Auguste ${ }^{4}$ des récits annalistiques comme l'Histoire romaine d'Ammien Marcellin, mais également des discours épidictiques, notamment les Panégyriques latins, et finalement les prémices d'une histoire universelle chrétienne avec Eusèbe ou Jérôme, n'est pas ancré dans un présent qui offre à l'historien matière à réfléchir sur la longue durée et son usage raisonné, du Principat à l'empire chrétien, par une nouvelle conception de la cité universelle et un nouvel équilibre, de part et d'autre des frontières d'un empire de plus en plus régulièrement franchies en tout sens... ${ }^{5}$ De la sorte, l'année 2015 aura fourni à tout Européen convaincu matière à de multiples interrogations quant aux conceptions politiques et territoriales aux contours fluctuants, ouvertes ou fermées, face à cette image poignante de migrants incarnant une nouvelle quête, l'Europe étant elle-même perpétuellement en recherche d'unité politique, sinon d'identité sociale. L'historien d'un Imperium Romanum le conduisant de la République médiane à l'Antiquité tardive ne s'égare nullement en ayant en tête cette brûlante actualité tout en réfléchissant à nouveaux frais sur la mobilité et les migrations dans le monde romain. Les propos qui suivent sont donc hic et nunc marqués par les temps présents et réaffirment la nécessité d'une mise en contexte permanente de tout écrit historique. Gageons qu'il n'est pas inutile de regarder le monde romain impérial depuis les rives d'une démocratie européenne désemparée, sinon aux abois!

du monde méditerranéen, t. II, Genèse d'un empire (Paris 1991), '1'impérialisme" romain', 883920; W.V. Harris, ed., The Imperialism of Mid-Republican Rome. Papers and Monographs of the American Academy in Rome 29 (Rome 1984), en particulier l'étude de J. Linderski, 'Si uis pacem, para bellum: Concepts of defensive imperialism', 133-164. En terminant par l'essai de J. Richardson, The Language of Empire. Rome and the Idea of Empire from the Third Century $B C$ to the Second Century $A D$ (Cambridge 2008). Pour un aperçu de l'historiographie française de l'Afrique du Nord, M. Dondin-Payre, 'Empire antique, empire contemporain: l'Afrique du Nord', in S. Benoist, A. Daguet-Gagey et Chr. Hoët-van Cauwenberghe, eds., Figures d'empire, fragments de mémoire. Pouvoirs et identités dans le monde romain impérial (II siècle avant notre ère-VI ${ }^{e}$ siècle de notre ère). Coll. Archaiologia (Villeneuve d'Ascq 2011), 49-70.

4 Pour reprendre la proposition de M. Thomson, 'The original title of the Historia Augusta', Historia 56 (2007), 123-125.

5 Quelques réflexions à paraître dans $\mathrm{S}$. Benoist, 'Biography, history and memory, about some imperial figures', All Souls College, 15 July 2015, Fergus Millar 8oth Birthday Celebration (London BICs Suppl.). 
Cette étude se propose de conduire une réflexion tout à la fois historiographique, méthodologique et prospective, en se fondant sur une documentation abordant prioritairement les statuts des hommes et des communautés sur un temps long, des héritages de la pratique républicaine - qui repose essentiellement sur les rapports entre Rome et les Latins, puis l'ensemble de la péninsule italienne, du cinquième au premier siècle avant notre ère - aux deux premiers siècles de l'empire, la constitutio Antoniniana représentant à bien des égards une étape, sinon un simple achèvement, d'un processus qui demeure une référence sans aucun équivalent dans la longue histoire des empires. ${ }^{6}$ La première partie de cette enquête porte sur une approche philologique et juridique de la mobilité à Rome et dans le monde romain, aux époques tardo-républicaine et impériale, en partant des termes polysémiques coloni et incolae. Le dossier des emplois épigraphiques de ces deux expressions, qui permet d'inverser les définitions naturelles des courants de la mobilité, du résident au migrant, conduit à aborder tout particulièrement dans un deuxième temps le problème de l'application du droit latin dans les communautés d'Occident. Une troisième partie conclusive revient sur les multiples conceptions de l'Imperium Romanum dans les réflexions récentes des historiens romanistes à propos de l'intégration, ou de l'homogénéité et de l'hétérogénéité de la société romaine impériale.

Le point de départ de cette enquête a été très clairement nourri par des travaux menés en France, dans les années 1980 et au tout début des années $1990 .{ }^{7}$ Des historiens et épigraphistes s'intéressaient aux statuts des hommes

6 C'est un élément fondamental insuffisamment commenté dans l'ouvrage récent tant débattu de J. Burbank et Fr. Cooper, Empires. De la Chine ancienne à nos jours (Paris 2011; trad. franç. de Empires in World History: Power and the Politics of Difference, Princeton, N.J. etc. 2010): voir de manière générale mes remarques dans $\mathrm{S}$. Benoist, 'Lecture et perspectives romaines', Monde(s), histoire, espaces, relations 2 (2012), 226-229, au sein de la rubrique 'Débat autour d'un livre'.

7 Mes premiers pas dans la recherche en France au milieu des années 1980 coïncident avec la tenue de séminaires, à l'École pratique des Hautes Études, section des Sciences historiques et philologiques, qui abordèrent des points essentiels pour mon propos et ont inspiré la reprise présente de ce travail. Il s'agit d'une part de la conférence de C. Nicolet qui exposait, à cette époque, les dossiers préparatoires à son maître livre sur L'inventaire du monde. Géographie et politique aux origines de l'Empire romain (Paris 1988 [2 éd. 1996]). On lira la présentation de cet ouvrage par M. Coudry, Cahiers du Centre Gustave Glotz 22 (2011), 111-122. D'autre part, le séminaire d'A. Chastagnol qui exploitait, avec la rigueur qui le caractérisait, la documentation épigraphique pour des études finalement regroupées dans son troisième volume de Scripta varia: La Gaule romaine et le droit latin, op. cit. (n. 1), paru il y a très exactement vingt ans. Si le premier abordait bien directement le problème de la mobilité, le second avait tout à fait à l'esprit l'importance de la dynamique constitutive de l'Imperium Romanum, en traitant des statuts des hommes et des communautés. 
et des communautés, mais également à la dynamique intégrative de l'empire romain et aux modes de fonctionnement politique et administratif de cette entité à nulle autre pareille, en ciblant la mémoire perdue des services romains ou les identités personnelles et collectives des cités de type romain, dont l'évolution dynamique s'apparente à une forme de cursus qui conduit de la cité pérégrine à la colonie romaine doté du ius Italicum. Cette capacité intégrative a dès lors inspiré les savants de toutes origines au cours des années 1990 et 2000, l'ensemble de la recherche tentant par des voies complémentaires et détournées de comprendre les spécificités du modèle romain. ${ }^{8}$ C'est donc bien dans une perspective ouverte sur la mobilité et les identités sociales et juridiques que je me place pour aborder dans ce qui suit un monde volontairement restreint à l'Occident romain, mais afin d'éclairer la compréhension d'un modèle d'empire hic et nunc.

2

\section{De la mobilité et des statuts: premières définitions. Peut-on parler d'identités' sociales et juridiques?}

Partons de cette proximité que je propose de retenir, en abordant tout à la fois la mobilité et les statuts, et rappelons brièvement quelques définitions qui sont autant de points de départ pour toute réflexion sur les manières romaines de penser la société civique, de définir la ciuitas. ${ }^{9}$ La circulation des hommes est apparue comme un enjeu qui cristallise les ressentiments de la part des alliés à l'égard des Romains et de leur évolution sensible entre les cinquième et quatrième siècles et la période postérieure, jusqu'à l'acmé d'une violente crise aux lendemains de la deuxième guerre punique qui finit par déboucher sur la guerre des socii et les dispositions juridiques qui s'en suivirent avec la

8 Un seul exemple suffira, avec la thèse de C. Ando, soutenue en 1996 et publiée en 200o: Imperial Ideology and Provincial Loyalty in the Roman Empire (Berkeley 2000).

9 C'est le premier objet d'étude de deux enquêtes récentes de C. Ando: L'Empire et le droit. Invention juridique et réalités historiques à Rome (Paris 2013), chap. 1 'Citoyens et étrangers devant la loi', et Roman Social Imaginaries. Language and Thought in Contexts of Empire (Toronto 2015), chap. 1 'Belonging'. On peut relever deux prémices à cette réflexion développées dans 'Law and the landscape of Empire', in S. Benoist, A. Daguet-Gagey et Chr. Hoëtvan Cauwenberghe, eds., Figures d'empire, fragments de mémoire. Pouvoirs et identités dans le monde romain impérial (II siècle avant notre ère-VI siècle de notre ère). Coll. Archaiologia (Villeneuve d'Ascq 2011), 25-47, et 'The Roman city in the Roman period', in S. Benoist, ed., Rome, a City and Its Empire in Perspective. The Impact of the Roman World through Fergus Millar's Research - Rome, une cité impériale en jeu. L'impact du monde romain selon Fergus Millar. Coll. Impact of Empire 16 (Leyde et Boston 2012), 109-124. 
municipalisation de l'Italie. ${ }^{10}$ Tout ceci est bien connu et ne sert que de toile de fond à ma réflexion. Je retiens donc, à partir d'une observation de Claude Nicolet qui s'intéressait tout particulièrement au contrôle de l'espace humain au moyen des recensements, que cette circulation des hommes domine largement le monde romain de l'époque républicaine avant que la circulation des documents signe une évolution majeure de l'organisation de l'Imperium Romanum et de la perception qu'il eut ou souhaita donner de lui-même. Je renvoie à ses analyses concernant cette connaissance du monde et aux deux citations suivantes pour appréhender la mobilité des hommes et le rôle du recensement: la remarque de Cicéron à propos de "cette foule venue de toute l'Italie pour les comices, les jeux, le recensement" et celle de Claude "combien une telle entreprise est pénible, nous le voyons bien maintenant par expérience, bien qu'il ne s'agisse aujourd'hui de rien d'autre que de faire connaître publiquement nos ressources." ${ }^{11}$ Il me semble que, dans une Italie devenue 'romaine' (nous sommes en 70), la remarque de Cicéron s'avère riche d'une lecture 'officielle' de ce qui fait le citoyen: comices, jeux et cens, à un moment où les hommes circulent encore, avant une décentralisation des opérations du cens dont nous informe la table d'Héraclée, les documents voyageant désormais pour des dénombrements statistiques centralisés à Rome, en lieu et place des hommes.

Il m’apparait, au regard de l'évolution de l'Italie et de sa lente mais irrésistible 'romanisation' au moyen du processus de municipalisation, que l'enjeu d'une mobilité sociale et juridique, qui s'était longtemps énoncée en termes de ius migrandi ou d'une acquisition per migrationem et censum, donc d'un déplacement effectif - physique - pour obtenir une promotion juridique, ${ }^{12}$ autre

10 L'une des meilleures approches et mises en perspective en français de ces phénomènes demeure les deux synthèses de J.-M. David, La Romanisation de l'Italie (Paris 1994) et La République romaine de la deuxième guerre punique à la bataille d'Actium, 218-31 av. J.-C. (Paris 2000).

11 Cic. I Verr. 54: Haec frequentia totius Italiae quae conuenit uno tempore undique comitiorum, ludorum, censendique causa; et la table claudienne de Lyon (CIL 13.1668 = ILS 212, II, 38-40): quod opus quam ar/duum sit nobis, nunc cum maxime, quamuis nihil ultra, quam/ ut publice notae sint facultates nostrae, exquiratur, nimis/ magno experimento cognoscimus; apud Nicolet 1988, op. cit. (n. 7), chapitre 6, 'Contrôle de l'espace humain: les recensements', 203, n. 18 et 199-200, 211, n. 66.

12 Se reporter à la mise au point récente (avec l'état bibliographique de la question) de D. Kremer, Ius Latinum. Le concept de droit latin sous la République et l'Empire (Paris 2006), 30-40, et en tout dernier lieu les réflexions de P. Le Roux, 'Le droit latin (ius latii): une relecture', in G. Cresci Marrone, ed., Trans Padum... usque ad Alpes. Roma tra il Po e le Alpi: dalla romanizzazione alla romanità (Rome 2015), 179-195, relecture de son désormais 
forme de déplacement, s'est transformé au profit d'une conception plus globale des différents statuts, de leur hiérarchie et d'un mouvement vers l'uniformisation. C'est en ce sens qu'il convient d'être attentif aux usages sémantiques, à la polysémie de certains termes et à l'ambiguïté de nos données concernant coloni et incolae, de la République à l'empire, tel que Yan Thomas tentait de les synthétiser en un volume très dense, dont je ne partage pas toutes les conséquences, notamment la conception évolutive du domicilium..$^{13}$ Assurément, les données dont nous disposons - littéraires, finalement assez réduites, épigraphiques, plus nombreuses mais parfois délicates à interpréter, et juridiques établissent une dualité structurelle (citoyens et résidents) qui rend compte d'une conception - certes à première vue traditionnelle de la cité antique, sinon constitutive, mais finalement plus ambiguë de la ciuitas, perçue, envisagée par les Romains. Des citoyens de plein droit (ciues, coloni ou municipes) cohabitent avec des résidents 'étrangers', au sens latin du terme peregrini, non-citoyens, mais dont l'origine a varié avec le temps, des ueteres incolae, les anciens habitants, les 'indigènes', aux incolae étrangers en résidence prolongée, ${ }^{14}$ qui n'ont pas cessé d'appartenir à leur ciuitas originelle.

Cette dualité des incolae se retrouve parfaitement dans toutes les études ayant abordé cette catégorie, des réflexions philologiques aux commentaires historiques, d'une définition du sens d'incola ${ }^{15}$ aux propos synthétiques d'une

classique article: 'Rome et le droit Latin', Revue historique de droit français et étranger 76.3 (1998), 315-341 = P. Le Roux, Espagnes romaines. L'empire dans ses provinces. Scripta Varia II, travaux rassemblés par S. Armani, F. Cadiou, et al. (Rennes 2014), 455-478.

13 Y. Thomas, 'Origine' et 'commune patrie'. Étude de droit public romain (89 av. J.-C.-212 ap. J.-C.). Coll. de l'École française de Rome 221 (Rome 1996). À ce propos, on renverra à la contribution de Claudia Moatti dans ce volume.

14 Ce critère de durée est formalisé sous Hadrien par la fixation d'une période de 10 ans: CJ 10. 40 (De incolis et ubi quis domicilium habere uidetur et de his qui studiorum causa in alia ciuitate degunt, "A propos des incolae, et pour tout lieu où un individu est censé avoir son domicilium, et à propos de ceux qui résident dans une autre cité en raison de la poursuite de leurs études"), 2 pr. (Imperator Alexander Severus. Nec ipsi, qui studiorum causa aliquo loci morantur, domicilium ibi habere creduntur, nisi decem annis transactis eo loci sedes sibi constituerunt, secundum epistulam diui Hadriani, nec pater, qui propter filium studentem frequentius ad eum commeat, "L'empereur Alexandre Sévère. Ceux qui demeurent dans quelque lieu que ce soit afin de poursuivre leurs études ne sont considérés comme ayant leur domicilium en ce lieu que s'ils y restent au moins dix ans. Selon une epistula du divin Hadrien, il n'en va pas de même pour un père qui visite fréquemment son fils, quand ce dernier poursuit ses études").

15 Définition du vocabulaire, à propos des coloni et incolae: le colonus est un "habitant d'une colonie (en grec, ärow A. Meillet, Dictionnaire étymologique de la langue latine. Histoire des mots (Paris 1959 $\left.{ }^{4}\right), 132$. 
étude portant sur Narbonne antique avec la célèbre inscription de l'autel au numen d'Auguste:

$\mathrm{T}$ (ito) Statilio Taur[o] / L(ucio) Cassio Longino / co(n)s(ulibus) $\mathrm{x}$ $\mathrm{K}$ (alendas) Octobr(es), / numini Augusti uotum / susceptum a plebe Narbo/nensium in perpetuom, / quod bonum faustum felixque sit $\operatorname{Imp}($ eratori) Caesari / diui $\mathrm{f}($ ilio) Augusto $\mathrm{p}$ (atri) $\mathrm{p}$ (atriae) pontifici maximo trib(unicia) potest(ate) / XxxIIII, coniugi, liberis gentique eius, senatui / populoque Romano et colonis incolisque / c(oloniae) I(uliae) $\mathrm{P}$ (aternae) $\mathrm{N}$ (arbonensis) $\mathrm{M}($ artii) qui se numini eius in perpetuum / colendo obligauerunt, plebs Narbonen/sium aram Narbone in foro posuit ad / quam quot annis viIII K(alendas) Octobr(es) qua die / eum saeculi felicitas orbi terrarum / rectorem edidit, tres equites Romani / a plebe et tres libertini hostias singu/las inmolent et colonis et incolis ad supplicandum numini eius thus et uinum / de suo ea die praestent, et VIII $\mathrm{K}$ (alendas) Octobr(es) / thus et uinum prae/stent $\mathrm{K}$ (alendis) quoque Ianuar(iis) thus et uinum / colonis et incolis praestent, viI quoq(ue) / Idus Ianuar(ias) qua die primum imperium / orbis terrarum auspicatus est thure / uino supplicent et hostias singul(as) in/molent et colonis incolisque thus ui/num ea die praestent, et pridie $\mathrm{K}$ (alendas) Iunias quod ea die $\mathrm{T}($ ito) Statilio / Tauro M(anio) Aemilio Lepido co(n)s(ulibus) iudicia / plebis decurionibus coniunxit hostias / singul(as) inmolent et thus et uinum ad / supplicandum numini eius colonis et / incolis praestent exque iis tribus equitibus Roman[is tribusue] / libertinis unu[s //

[Pleb]s Narbone(n)sis a[ram] / numinis Augusti de[di]cauit [3] / [6] / [3] legibus iis q(uae) $i($ nfra) $s$ (criptae) $s($ unt), numen Caesaris Aug(usti) $\mathrm{p}$ (atris) $\mathrm{p}$ (atriae) quando tibi / hodie hanc aram dabo dedicabo/que his legibus hisque regioni/bus dabo dedicabo quas hic / hodie palam dixero uti infimum / solum huiusque arae titulorum/que est si quis tergere ornare / reficere uolet quod beneficii / causa fiat ius fasque esto siue / quis hostia sacrum faxit qui / magmentum nec protollat id/circo tamen probe factum esto si / quis huic arae donum dare au/gereque uolet liceto eademq(ue) / lex ei dono esto quae arae est / ceterae leges huic arae titulisq(ue) / eadem sunto quae sunt arae / Dianae in Auentino hisce legi/bus hisque regionibus sicuti / dixi hanc tibi aram pro Imp(eratore) / Caesare Aug(usto) $\mathrm{p}$ (atre) $\mathrm{p}$ (atriae) pontifice maxi/mo tribunicia potestate XXXV coniuge liberis genteque eius / senatu populoque $\mathrm{R}$ (omano) colonis / incolisque col(oniae) Iul(iae) Patern(ae) Narb(onensis) Mart(ii) qui se numini eius in per/petuum colendo obligauerunt / doque dedicoque uti sies uolens / propitium. 
[Face principale] Sous le consulat de T. Statilius Taurus et de L. Cassius Longinus, dix jours avant les kalendes d'Octobre (22 septembre 11 de notre ère), vœu consacré par la plèbe de Narbonne au numen d'Auguste à perpétuité, afin qu'il soit bon, prospère et heureux pour l'empereur César Auguste, fils du Diuus, père de la patrie, grand pontife, revêtu de sa XXXIV ${ }^{\mathrm{e}}$ puissance tribunicienne, son épouse, ses enfants et sa famille, le Sénat et le peuple romain, les colons et les domiciliés de la colonie Julia Paterna Narbo Martius qui se sont engagés à rendre un culte perpétuel à son numen. La plèbe de Narbonne a élevé sur le forum à Narbonne un autel auprès duquel, chaque année, neuf jours avant les kalendes d'octobre (23 septembre), jour où le bonheur du siècle l'a fait naître (ce prince) pour gouverner le monde, trois chevaliers recommandés par la plèbe et trois affranchis immoleront chacun une victime et fourniront à leurs frais aux colons et aux domiciliés l'encens et le vin pour adresser des prières à son numen. Huit jours avant les kalendes d'octobre (24 septembre), ils fourniront aussi l'encens et le vin aux colons et aux domiciliés. Aux kalendes de janvier, ils fourniront aussi l'encens et le vin aux colons et aux domiciliés. Et de même, sept jours avant les ides de janvier ( 7 janvier), jour où pour la première fois il a inauguré son imperium sur le monde, ils adresseront des prières par l'encens et le vin, immoleront chacun une victime et fourniront l'encens et le vin aux colons et aux domiciliés. Et la veille des kalendes de juin (30 mai), parce qu'en ce jour, sous le consulat de T. Statilius Taurus et de M. Aemilius Lepidus, il adjoignit des juges plébéiens aux décurions, ils immoleront chacun une victime et fourniront aux colons et aux domiciliés l'encens et le vin pour adresser des prières à son numen. Et de ces trois chevaliers et de ces [trois] affranchis, un seul $[\ldots]$

[Face latérale] La plèbe de Narbonne a dédié l'autel au numen d'Auguste [...] selon les lois qui ont été écrites ci-dessus. Numen de César Auguste, père de la patrie, lorsqu'en ce jour je te donnerai et te dédierai l'autel que voici, je te le donnerai et te le dédierai suivant les lois et dans les limites que j'aurai publiquement ici, en ce jour, énoncées, de même que le sol où reposent l'autel et les inscriptions. Si quelqu'un veut nettoyer, orner, restaurer, à titre de bienfait, que cela soit permis par les lois humaines et divines; si quelqu'un fait le sacrifice d'une victime sans différer l'offrande supplémentaire, que cela soit cependant tenu pour régulier. Si quelqu'un veut faire un don à cet autel et l'enrichir, qu'il en ait la permission et que la même loi qui s'applique à l'autel s'applique aussi à ce don. Que pour cet autel et les inscriptions, les autres lois soient les mêmes que celles de l'autel de Diane sur l'Aventin. Suivant ces lois et dans ces limites, comme 
je l'ai dit, c'est à toi que, pour l'empereur César Auguste, père de la patrie, grand pontife, revêtu de la $\mathrm{Xxxv}^{\mathrm{e}}$ puissance tribunicienne, pour son épouse, ses enfants et sa famille, le Sénat et le peuple romain, les colons et les domiciliés de la Colonie Julia Paterna Narbo Martius, qui se sont engagés à rendre un culte perpétuel à son numen, je donne et dédie cet autel pour que tu sois favorable et propice. ${ }^{16}$

André Chastagnol, en analysant très précisément une documentation épigraphique qui le conduisit de la fin de la République au premier siècle de l'empire, visait à définir au mieux (et notamment au travers des données onomastiques) ce que furent coloni et incolae. Il avait en particulier bien souligné cette distinction 'paradoxale': les deux termes dérivant du même verbe - colo, colere $=$ habiter, cultiver la terre -, mais en distinguant désormais les nouveaux habitants venus du dehors, cultivateurs du sol qui leur a été attribué, exerçant seuls les droits politiques et les transmettant à leurs descendants, les coloni, des habitants libres du territoire colonial, indigènes pérégrins qui ne participaient plus à la vie politique de la cité dont ils étaient pourtant originaires. ${ }^{17}$

Dans cette première lecture, statique, de l'expression, les migrants sont les coloni et les natifs les incolae, ce que le temps passant, avec le processus de romanisation des provinciaux qui s'est mis en marche, allait totalement inverser pour parvenir à la lecture de nos sources juridiques plus tardives qui désignent désormais l'étranger résident en tant qu'incola, produit d'une mobilité au cœur d'un empire 'globalisé', pour employer une formulation qui a les faveurs de l'histoire contemporaine 'connectée' depuis une bonne dizaine d'années déjà. Cette question des domiciliés de l'intérieur et de l'extérieur, d'un glissement de sens qui s'opère au cours du premier siècle du Principat, nous permet d'aborder désormais le cour de notre réflexion portant sur la dynamique propre du modèle juridictionnel de l'imperium Romanum.

16 La présence des coloni incolaeque dans le texte de l'Autel de Narbonne daté de 11 de n.è. $(C I L 12.4333=I L S 112)$ est tout à fait remarquable. On peut y ajouter la réflexion et les commentaires de Michel Gayraud dans son Narbonne antique des origines à la fin du III siècle (Paris 1981), 353: "quant aux incolae, il ne faut pas y voir les seuls indigènes non romanisés, mais plutôt l'ensemble des habitants domiciliés qui ne sont pas citoyens de la colonie mais qui s'y sont fixés intentionnellement."

17 Chastagnol 1996, op. cit. (n. 1), 13-25 = idem 1995, op. cit. (n. 1), 131-141, plus particulièrement pour ce qui nous concerne ici $14=132$. 


\section{Coloni et incolae, un dossier impérial. De la conception englobante et évolutive du droit romain}

La proximité sémantique de ces deux termes, étroitement associés dans un certain nombre d'inscriptions et dans quelques textes littéraires et juridiques, rend compte d'une réalité institutionnelle et sociale tout à fait prégnante. Ces deux ensembles distincts au sein des cités (qu'il s'agisse des coloniae ou des municipia, voire des ciuitates pérégrines), les coloni et les incolae, coexistent et collaborent. La reconnaissance de ces derniers est explicite, en tant qu'étrangers inscrits comme résidents (se reporter à la loi d'Osuna, Lex Vrsonensis, Lex Coloniae Genetiuae $)^{18}$ - je reviendrai pour le premier siècle de l'empire sur les cas des ueteres incolae -; ils se voient dès lors dotés d'un certain nombre de privilèges: de la participation aux distributions collectives ${ }^{19}$ à des rangs réservés

$18 C I L 2-5.1022=2.5439$ et $5439 \mathrm{a}=I L S 6087$ : chapitres XCV $($ qui colon $(i) /$ incolaeue erunt quibus); CIII (colon(os) / incolasque contributos) et CXXvi (colonos Geneti/uos incolasque hospites(que) atuentoresque).

19 Pour la désignation des ciues d'une colonie en tant que coloni, mais également comme municipes, nous pouvons relever, à propos de la colonie de Sicca Veneria (Le Kef), l'emploi très rare d'un terme pour l'autre dans une expression faisant référence aux municipes et incolae, CIL 8.1641 = ILs 6818, Sicca Veneria: P(ublio) Licinio M(arci)f(ilio) Quir(ina tribu) / Papiriano, procur(atori) / Augg(ustorum duorum) Imp(eratoris) Caes(aris) M(arci) Aureli(i) / Antonini Aug(usti) Germanici / Sarmatici maximi, p(atris) p(atriae), et / [di]ui Veri, a rationibus cui / splendissimus ordo Siccen/sium ob merita eius et cu[ram(?) 3] / [3] M et [3] / [6] / M[3]N[3] / [6] / [6] / [3]LEC[3] / [3]T[3] / [3]II[ // Municipibus meis Cirthensibus / Siccensibus carissimis mihi dare / uolo HS MCCC(milia). Vestrae fidei committo, / municipes carissimi, ut ex usuris / eius summae quincuncibus quodan/nis alantur pueri CCC et puellae CC, pueris / ab annis tribus ad annos XV et accipiant / singuli pueri |(denarios) II s(emissem) menstruos, puellae / ab annis tribus ad annos XIII |(denarios) II. Legi / autem debebunt municipes item in/colae, dumtaxat incolae qui intra / continentia coloniae nostrae ae/dificia morabuntur; quos, si uo/bis uidebitur, optimum erit per / IIuiros cuiusque anni legi; cura/ri autem oportet, ut in locum ad/ulti uel demortui cuiusque sta/ tim substituatur ut semper ple/nus numerus alatur. "A Publius Licinius Papirianus, fils de Marcus, de la tribu Quirina, procurateur a rationibus des deux Augustes, l'empereur César Marcus Aurelius Antoninus Auguste Germanicus Très grand Sarmatique, père de la patrie, et le divin Verus, à qui le très splendide ordre des habitants de Sicca pour ses mérite et soin [...] (Sur le côté gauche) A mes très chers concitoyens (municipes) de Cirta Sicca, je veux donner 1,300,000 sesterces. Je m'en remets à votre bonne foi, très chers municipes, pour qu'avec les intérêts aux $5 / 12^{\mathrm{e}}$ de la somme chaque année on nourrisse 300 garçons et 200 filles; que les garçons, de 3 à 15 ans, reçoivent chacun 2,5 deniers par mois; les filles, de 3 à 13 ans, chacune 2 deniers par mois. Et l'on devra choisir des citoyens ainsi que des résidents, pourvu que les résidents demeurent dans l'agglomération de notre colonie. Ceux-ci, si vous l'acceptez, il sera mieux qu'ils soient choisis par les duumvirs 
au théâtre, jusqu'à des droits judiciaires, voire au droit de vote, enfin à l'admission dans la curie (l'ordre des décurions), comme l'attestent les inscriptions de Die et Axati. On peut s'appuyer, pour quelques exemples significatifs, sur les relevés de François Bérard, à propos notamment de Sex. Vencius Iuventianus, un notable admis dans la curie en tant que résident étranger:

Dea Augusta Vocontiorum: Sex(to) Vencio / Iuuentiano, / flamini diui Aug(usti) / item flamini et cura/tori muneris gladi/atori(i) Villiani, adlec/ to in curiam Lugudu/nensium (sic!) nomine / incolatus a splen/didissimo ordine / eorum, / ordo Vocontior(um) / ex consensu et pos/tulatione populi / ob praecipuam / eius in edendis / spectaculis li/beralitatem.

A Sextus Vencius Iuventianus, flamine du divin Auguste, et aussi flamine et curateur du combat de gladiateurs Villianus, agrégé dans la curie des Lyonnais en tant que résident par leur très splendide ordre, l'ordre des Voconces, avec l'accord et sur demande du peuple, en raison de sa particulière libéralité dans l'organisation des spectacles. ${ }^{20}$

avec le parallèle du municipe flavien d'Axati, et l'exemple de L. Lucretius Severus, ex incolatu decurioni:

L(ucio) Lucretio Seuero / Patriciensi / et in municipio / Flauio Axatitano / ex incolatu decurioni / statuam quam testamento / s(uo) poni sibi iussit / datis sportulis / decurion[ibus m(unicipum)] / m(unicipii) F(laui) Axatitani [3] / [3]simus XII[.

A Lucius Lucretius Severus, Patriciensis et décurion dans le municipe flavien d'Axati parmi les résidents, la statue que, dans son testament, il a ordonné qu'on lui élève; des sportules ont été distribuées aux décurions des municipes du municipe flavien d'Axati [---]. ${ }^{21}$

de chaque année, et il faudra aussi se préoccuper de remplacer sans attendre les adultes ou les défunts, pour qu'on nourrisse toujours un groupe complet." Pour deux analyses de cette fondation alimentaire qui bénéficie aux deux composantes de la cité: $\mathrm{M}$. Christol et A. Magioncalda, 'La fondazione di P. Licinio Papiriano da Sicca Veneria', L'Africa Romana 8 (1991), 321-330, et N. Kallala, 'À propos de la fondation de P. Licinius Papirianus de Sicca Veneria (CIL VIII, 1641): Quelques mises au point', Africa 20 (2004), 109-120. 
et le dossier des droits politiques octroyés aux incolae, notamment enrichi par le chapitre 53 de la Lex Flauia Malacitana:

[53] r(ubrica) in qua curia incolae suffragia / ferant / quicumque in eo municipio comitia Iluiris / item aedilibus item quaestoribus rogan/dis habebit ex curiis sorte ducito unam / in qua incolae qui ciues $\mathrm{R}$ (omani) Latiniue ciues / erunt suffragi $\{0\}<u m>$ ferant eisque in ea cu/ria suffragi latio esto / (...)

Dans quelle curie votent les incolae. Celui qui tiendra les comices dans ce municipe pour élire les duumvirs, ainsi que les édiles, de même que les questeurs, devra tirer au sort l'une des curies dans laquelle voteront les résidents, qu'ils soient citoyens romains ou citoyens latins, et ils auront le droit de vote dans cette curie. ${ }^{22}$

De fait, lévolution de la signification du terme incola rend bien compte des mutations de la société romaine impériale et de sa capacité à l'intégration sociale, puis juridique, de populations 'indigènes' confrontées aux résultats de la conquête de territoires, de la déduction de colonies avec installation - parfois multiple - de vétérans ou de plébéiens civils, ${ }^{23}$ à l'installation dans des communautés de type romain d'étrangers domiciliés et reconnus comme tels, au-delà du laps de temps jugé nécessaire (voir n. 14 supra). Ces migrants de l'extérieur que le droit définit très précisément au deuxième siècle avec Pomponius et Gaius, ${ }^{24}$ en tant que domiciliés, devant obéissance aux magistrats, en particulier

22 CIL 2. $1964=I L S 6089$. Mobilité géographique et mobilité sociale, à propos des incolae admis à la curie: F. Bérard, 'L’organisation municipale de la colonie de Lyon', in M. DondinPayre et M.-Th. Raepsaet-Charlier, eds., Cités, municipes, colonies. Les processus de municipalisation en Gaule et en Germanie sous le Haut Empire romain. Coll. Histoire ancienne et médiévale 53 (Paris 1999, 2 $2^{\mathrm{e}}$ tirage 2009), 97-126, ici 108-109. De manière générale, on renverra à la synthèse des données concernant le fonctionnement des institutions des cités que l'on doit à M. Dondin-Payre, 'Magistratures et administration municipale dans les Trois Gaules', in M. Dondin-Payre et M.-Th. Raepsaet-Charlier, eds., Cités, municipes, colonies. Les processus de municipalisation en Gaule et en Germanie sous le Haut Empire romain. Coll. Histoire ancienne et médiévale 53 (Paris 1999, $2^{\mathrm{e}}$ tirage 2009), 127-230.

23 On peut citer l'exemple de Narbonne, avec une installation de civils en 118, puis de vétérans de la Xe légion en 45. Voir Gayraud 1981, op. cit. (n. 16).

24 Les dispositions du droit romain (au deuxième siècle), à propos des domiciliés d'origine étrangère sont les suivantes: Incola est, qui aliqua regione domicilium suum contulit; quem Graeci paroikon appellant "Est résident, celui qui place son domicile dans telle région; c'est ce que les Grecs appellent 'paroikon' (voisin, habitant auprès de)", Dig. 50. 16 
le respect de leurs charges politiques et fiscales, sont donc une composante des ciuitates, dans le cadre d'une évolution remarquable des statuts des hommes et des communautés tout au long de ces deux premiers siècles de l'empire. Ainsi, la figure impériale est souvent présente quand il s'agit de mesurer la composition mixte de ces communautés: qu'il s'agisse de l'autel de Narbonne, en 11 de notre ère, qui permet d'attester l'association étroite des domiciliés (étrangers ou indigènes) au culte organisé en l'honneur du numen d'Auguste (se reporter supra au texte cité) avec toutes les implications d'un calendrier local aux fortes connotations romaines - ce qui participe de ce mouvement de construction d'une communis patria 'impériale', au sens où l'empereur en est le garant et le promoteur -, ou bien du témoignage d'Aoste, dans une dédicace à Auguste patron de la colonie qui mentionne les Salassi incolae présents depuis l'origine (initio). ${ }^{25}$ La fondation de Terentius Varron en 25 (Augusta Praetoria), sur l'emplacement de son camp militaire, comprend donc l'installation de 3,00o vétérans, selon Strabon et Dion Cassius, ainsi que des Salasses qui devaient faire partie de ceux qui avaient fait reddition avant la fin du conflit, hommes libres inscrits aux côtés des coloni. ${ }^{26}$ La dédicace date des tout débuts de la colonie, en 23-20 avant notre ère. Cet exemple permet d'évoquer à propos de ces 'étrangers de l'intérieur' le sort des vaincus et les déplacements de population que cela a pu générer $(36,000$ personnes, dont 8,00o combattants, furent vendus comme esclaves, toujours selon nos sources littéraires).

Le dossier d'Avenches ${ }^{27}$ me permet de terminer cette évocation de la mention des coloniet incolae dans les cités de l'Occident romain au premier siècle de l'empire, le glissement de sens sur lequel nous reviendrons en dernière partie,

(De uerborum significatione), 239. 2 (Pomponius libro singulari enchiridii); Incola et his magistratibus parere debet, apud quos incola est, et illis, apud quos ciuis est, "Le résident doit à la fois obéir aux magistrats auprès desquels il est résident et à ceux auprès desquels il est citoyen", Dig. 50. 1 (Ad municipalem et de incolis), 29 (Gaius 1 ad edictum prouinciale).

Pour le cas de la colonie d'Aoste, ILS 6753 = IIt. 11.1, 6; A.M. Cavallaro et G. Walser, Iscrizioni di Augusta Praetoria (Aoste 1988), no. 1, Augusta Praetoria: Imp(eratori) Caesa[ri] / diuif(ilio) August(o) / co(n)s(uli) XI, imp(eratori) VI[II], / tribunic(ia) pot(estate), / Salassi incol(ae), / qui initio se / in col(onia) con[t(ulerunt)], / patron(o). "A l'empereur César Auguste, fils du divin, consul onze fois, salué imperator huit fois, revêtu de la puissance tribunicienne, les résidents Salasses, qui sont placés depuis son origine dans la colonie, à leur patron."

26 Strab. 4. 6.7 et C.D. $53 \cdot 25 \cdot 3-5$.

27 À propos de la colonie d'Avenches, se reporter à l'article de R. Frei-Stolba, avec A. Bielman et H. Lieb, 'Recherches sur les institutions de Nyon, Augst et Avenches', in M. DondinPayre et M.-Th. Raepsaet-Charlier, eds., Cités, municipes, colonies. Les processus de municipalisation en Gaule et en Germanie sous le Haut Empire romain. Coll. Histoire ancienne et médiévale 53 (Paris 1999, 2 e tirage 2009), 29-95, part. 'La ciuitas Heluetiorum', 67-91. 
des étrangers de l'intérieur aux étrangers domiciliés, et l'épineuse question du statut des communautés que je ne souhaite pas aborder de front dans le cadre de cette brève réflexion - colonies romaines, colonies latines et municipes de droit latin. Toutefois, deux expressions, qui ont entraîné de nombreux débats dans la communauté scientifique, vont me permettre de poser les jalons de ma toute dernière partie conclusive. Il s'agit des trois curatores col. connus, avec notamment l'exemple de T. Tertius Severus, et des patroni publici. ${ }^{28}$ Dans le premier cas, il s'agit de trois dédicaces à la déesse tutélaire de la colonie, Dea Auentia, qui mentionnent quatre personnages dont les profils s'apparentent à des incolae - un Trévire est nommément attesté. ${ }^{29} \mathrm{Si}$ l'on a proposé de développer en curator colonorum (Patrick Le Roux en dernier lieu), il s'agirait alors d'une association de colons déduits et installés à Avenches, considérée comme une colonie romaine, ce qui pose le problème du profil des curateurs et de la présence des incolae. On rejettera de même la solution d'une simple haplologie, curator (incolarum) col(oniae), et l'on préférera la cura confiée à un riche individu, incola qui se voit ainsi reconnu, à défaut de pouvoir faire une carrière de magistrat. ${ }^{30} \mathrm{Ce}$ qui serait également le sens de ces patroni publici, pris

28 Concernant les coloni Auenticenses, les incolae Auenticenses, les curator col(-) et les patroni publici, Frei-Stolba 1999 op. cit. (n. 27), 85-88, 'Les curatores col(-)'

CIL 13. 5073 = ISchweiz $207=$ RIS 75, Avenches: Deae Auentiae / et Gen(io) incolar(um) / T(itus) Ianuarius / Florinus / et P(ublius) Domitius / Didymus, / curatores col(oniae), ex stipe annua / adiectis de suo / HS n (ummum) I(mille)D. "A la déesse Aventia et au Génie des incolae, Titus Ianuarius Florinus et Publius Domitius Didymus, curateurs de la colonie, avec les revenus annuels, ajoutant à leurs frais la somme de 1,500 sesterces." CIL 13.5071 = ISchweiz 209, Avenches: Deae Auent(iae) / C(aius) Iul(ius) Primus / Treuir, / cur(ator) col(oniae), item / cur(ator) IIIIIIuir(um), / de suo posuit / [6] / [3]RII[3] / l(ocus) d(atus) d(ecreto) [d(ecurionum $)]$. "A la déesse Aventia, Caius Iulius Primus, Trévire, curateur de la colonie, de même curateur des sévirs, a posé à ses frais [...], emplacement donné par décret des décurions." CIL 13. $5072=$ ISchweiz 208 = RIS 74, Avenches: Deae Auent(iae) $/ T$ (itus) Tertius /Seuerus, / cur(ator) colon(iae)/idemque all(ector), / cui incolae /Auenticens(es) / prim(o) omnium / ob eius erga / se merita / tabulam arg(enteam) / $p[u b] l($ ice?) / posuer(unt) / donum d(e) s(ua) p(ecunia) / ex HS V(milibus)CC, l(ocus) d(atus) d(ecreto) d(ecurionum). "A la déesse Aventia, Titus Tertius Severus, curateur de la colonie, et de même membre du collège, auquel, le premier de tous, les résidents d'Avenches, pour ses mérites envers eux, ont posé cette table d'argent publiquement, a fait don sur ses propres fonds de 5,200 sesterces, emplacement donné par décret des décurions."

Résumé des différentes positions par Frei-Stolba 1999, op. cit. (n. 27), 85-87, avec notamment successivement, pour les trois hypothèses proposées: P. Le Roux, 'La question des colonies latines sous l'Empire', Ktéma 17 (1992), 183-200; P. Frei, 'Zur Gründung und zur Rechtsstellung der römischen Kolonie Aventicum', Bulletin de l'Association Pro Aventico 20 (1969), 5-22 et finalement J. Krier, Die Treverer ausserhalb ihrer Civitas (Trèves 1981). 
sur place, d'origine locale, aux côtés des grands personnages, marquant ainsi des liens étroits entre coloni et incolae Auenticenses. ${ }^{31}$ Dans cette approche, les mécanismes propres au droit latin ont par ailleurs, en un temps relativement court, concouru à une unification des statuts - par le biais d'une diffusion régulière de la ciuitas Romana, par le ius Latii puis le Latium maius -, et une fusion des communautés - le statut des incolae changeant radicalement de signification au fur et à mesure de la diffusion de la citoyenneté romaine --, sur lesquelles je souhaiterai achever mon propos.

Fiction juridique, dynamique intégrative et conception de l'Imperium Romanum, de l'hétérogénéité à l'homogénéité: remarques conclusives en marge de deux livres récents de Clifford Ando

Un premier constat s'impose, qui est riche de sens pour l'enquête commune engagée sur mobilité et migration: les mécanismes de l'expansion romaine se fondent sur des jeux de miroir, d'identités en regard. Le migrant (le colon romain) s'enracine dans un territoire et transforme les populations locales en résidents, partageant une communauté, sinon en droit, et se fondant à terme dans une collectivité plus large d'étrangers résidents, les nouveaux migrants dont les statuts personnels peuvent varier, du pérégrin au citoyen romain, ceux-là même qui devront justifier d'une durée minimale d'installation dans la cité.

La fictio ciuitatis qu'étudie C. Ando, dans la littérature jurisprudentielle (avec Gaius notamment), s'accompagne de rapports structurants qui permettent de penser la communis patria en autant de couples antithétiques, qui sont voués à une certaine fusion, au terme de trois à quatre siècles d'histoire impériale: ciuis/peregrinus (avec les effets de l'édit de Caracalla, ou Constitutio Antoniniana); colonus/ incola (dans une dynamique des échanges), réductible à l'identification ciuitas/ Imperium Romanum, ce qui pose en définitive le

$31 \quad C I L$ 13. 5091 = ISchweiz $211=$ RIS 83, Avenches: $]$ IEIVI[3] / quaestura in $p[$ rou $($ incia $)] /$ Asia functu[s est], / incolae Auent[ic]ens(es) / ob egreg(ia) eius erga se mer(ita) / patron(o) p(ublice), cui singuli / adq(ue) uniuers(i) obligatos / se esse praeferunt adq(ue) / etiam parum sibi ui/dentur praedicare / cura T(iti) Nigr(ini) Modesti / IIIIIIuiri Augustalis. "[---] il a accompli la questure dans la province d'Asie, les résidents d'Avenches, en raison de ses remarquables mérites envers eux, à leur patron, publiquement, auquel ils se sont présentés comme étant ses obligés, à titre indivituel comme à titre collectif, tout comme ils semblent le célébrer, sous la conduite de Titus Nigrinus Modestus, sévir augustal." 
problème du rapport entre Rome et les cités provinciales, et la question d'une conception globale, universelle, d'un paradoxe de l'exclusion qui aboutit à l'inclusion (saluo iure patroni, saluo iure gentis). Les productions normatives impériales concourent à cette mutatio stationis, tant à l'échelle individuelle qu'au stade collectif. L'empire, cité universelle, se construit à partir d'une pluralité de statuts personnels et collectifs et de processus de fusion.

En définitive, j'adhère volontiers à l'idée d'une production de l'homogénéité à partir de l'hétérogénéité, mais interprète différemment les réflexions d'Hadrien, rapportées par Aulu-Gelle et analysées par C. Ando:

Sed coloniarum alia necessitudo est; non enim ueniunt extrinsecus in ciuitatem nec suis radicibus nituntur, sed ex ciuitate quasi propagatae sunt et iura institutaque omnia populi Romani, non sui arbitrii, habent. Quae tamen condicio, cum sit magis obnoxia et minus libera, potior tamen et praestabilior existimatur propter amplitudinem maiestatemque populi Romani, cuius istae coloniae quasi effigies paruae simulacraque esse quaedam uidentur, et simul quia obscura oblitterataque sunt municipiorum iura, quibus uti iam per ignotitiam noli queunt.

Mais ce qui lie les colonies est différent: car elles ne viennent pas de l'extérieur pour entrer dans le corps citoyen et elles ne sont pas nourries par leurs propres racines, mais elles sont propagées à partir du corps citoyen lui-même et ont toutes les lois et les institutions du peuple romain, sans les avoir elles-mêmes choisies. Ce statut, cependant, bien que plus pesant et moins libre, est pourtant considéré comme préférable et plus digne, si l'on tient compte de la magnificence et de la grandeur du peuple romain, dont ces colonies semblent être l'image et des sortes de copies; et, en même temps, parce que les lois des municipia sont obscures et oubliées, par ignorance, celles-ci ne sont pas en état d'en faire usage. ${ }^{32}$

Que dire donc de cette aspiration au statut colonial face au statut municipal, jugé pourtant plus libre, dans ce qui apparaît comme une sorte de cursus honorum menant de la ciuitas à la colonie dotée du ius Italicum, autre avatar de la fiction juridique et spatiale de la communis patria?33

32 Aul.Gel. NA 16.13. 8-9. De la colonie, du municipe, de la conception des statuts personnels, des communautés et de l'Imperium Romanum, en se reportant à Ando 2013, op. cit. (n. 9), 230.

33 Au sens que le Digeste avec Modestin lui assigne: Roma communis nostra patria est (Herennius Modestinus, Manualia, 1 = Dig. 50.1.33; également Dig. 27.1.6.7). On se reportera 
Le rapport entre coloni et incolae et celui entre colonies et municipes m’apparaît du même ordre, de la différence à l'identité, du pareil au même, dans un mouvement paradoxal de la mobilité des statuts, de la migration flux vital - au sein d'une cité universelle, mouvement nécessaire qui, une fois brisé, renvoie l'utopie à l'émiettement tardo-antique. Dans cette perspective, l'histoire continue et le quatrième siècle, sur lequel nous avons ouvert cette réflexion, permettrait d'analyser le devenir des fictions juridiques et les effets des migrations des peuples, réinventant une nouvelle approche de la cité impériale, au-delà des ruptures effectives ou fluctuantes des partes occidentalis et orientalis. ${ }^{34}$

Rome-Paris, Juin 2015-Février 2016

aux développements de Thomas 1996 op. cit. (n. 13). Pour une remise en perspective impériale d'une évolution sur la longe durée, $\mathrm{S}$. Benoist, 'Le prince, magister legum: réflexions sur la figure du législateur dans la Rome impériale', in P. Sineux, ed., Le législateur et la loi dans l'Antiquité. Hommage à Françoise Ruzé (Caen 2005), 225-240, complété par idem, 'Penser la limite: de la cité au territoire impérial', in O. Hekster et T. Kaizer, eds., Frontiers in the Roman World. Proceedings of the Ninth Workshop of the International Network Impact of Empire (Durham, 16-19 April 2009) (Leyde et Boston 2011), 31-47.

34 On pourrait tirer ainsi profit, pour la présente réflexion, d'une lecture affinée de l'Expositio totius mundi et gentium et des mouvements successifs de codification impériale. On peut prendre en outre un seul exemple avec cette étude récente de l'évolution tardo-antique de la Gaule dans ce cadre: A.E. Jones, Social Mobility in Late Antique Gaul: Strategies and Opportunities for the Non-elite (Cambridge et New York 2009). 


\title{
Migration et droit dans l'Empire Romain Catégories, contrôles et intégration
}

\author{
Claudia Moatti
}

\section{Introduction}

A considérer les travaux sur la mobilité antique, deux idées semblent susciter un certain consensus: celle de la fluidité des échanges et celle de la faiblesse administrative de l'Etat romain, ou de son indifférence au mouvement des hommes. ${ }^{1}$ Le programme La mobilité des personnes en Méditerranée de l'Antiquité à l'époque moderne, organisé entre 2002 et 2009, visait au contraire à réintégrer le politique et le droit, en étudiant les modes de régulation de la circulation humaine et leurs logiques. ${ }^{2}$ Il ne s'agissait pas de proposer une vision policière du contrôle, mais d'évaluer le rôle des autorités dans le processus de migration; de comprendre également, de manière plus réflexive, par l'étude des normes et de l'interprétation juridique, la place que les sociétés antiques et modernes reconnaissaient à la mobilité, et les représentations qu'elles en concevaient. C'est dans la continuité de ce travail que je me propose

1 Voir par exemple J. Gagé, Les classes sociales dans l'Empire romain (Paris 1964); M. Reinhold, 'Usurpation of status and status symbols in the Roman Empire', Historia (1971), 276; ou encore S. Mitchell, 'Requisitioned transport in the Roman Empire. A new inscription from Pisidia', Journal of Roman Studies 66 (1976), 196. L'idée d'une fragmentation entre les micro-régions de la Méditerranée, qui serait compensée par une connectivité favorisée par le mer, renforce cette perception que nous pourrions dire libérale de l'espace méditerranéen. Ce modèle, abondamment repris par l'historiographie récente, a été promue notamment par N. Purcell et P. Horden, The Corrupting Sea (Londres 200o); sur la faiblesse de l'Etat, voir récemment T.T. Terpstra, Trading Communities in the Roman World: A Micro-economic and Institutional Perspective (Leiden 2013); P.F. Bang, The Roman Bazaar. A Comparative Study of Trade and Markets in a Tributary Empire (New York et Cambridge 2008).

2 C. Moatti, éd., La mobilité des personnes en Méditerranée, de l'Antiquité à l'époque moderne. Procédures de contrôle et documents d'identification. Coll. de l'Ecole française de Rome 341 (Rome 2004); C. Moatti et W. Kaiser, éds., Gens de passage dans les villes méditerranéennes, de l'Antiquité à l'époque moderne. Procédures de contrôle et d'identification (Paris 2007); C. Moatti, W. Kaiser et Chr. Pébarthe, éds., Le monde de l'itinérance en Méditerranée, de l'Antiquité à l'époque moderne. Procédures de contrôle et d'identification (Bordeaux 2009). 
de présenter ces quelques réflexions. Comment le droit romain a-t-il saisi la mobilité, avec quelles catégories? Peut-on parler de politiques migratoires ou de politiques d'accueil dans l'empire? Peut-on enfin mesurer l'impact de la production normative sur la mobilité et celle de la mobilité sur l'empire?

L'un des apports les plus intéressants des travaux d'histoire contemporaine ou de sciences sociales a consisté à étudier la migration non plus comme un moment exceptionnel et déracinant, qui coupe en deux la vie du migrant mais comme un 'processus social' qui englobe aussi bien le départ et l'arrivée que les étapes ou encore les retours, et qui concerne toutes sortes de déplacements de plus ou moins grande distance: ${ }^{3}$ la notion de migration a donc subi une extension, pour être englobée dans celle, plus large, de mobilité. De la même façon, le concept de diaspora a perdu sa dimension répressive et victimaire, pour désigner tout mouvement de longue durée durant lequel les personnes en mobilité gardent un lien mémoriel ou réel avec leur lieu d'origine. ${ }^{4}$ On parlera ainsi, suivant le modèle de Abner Cohen, de la diaspora des marchands, de celle des administrateurs ou des soldats. ${ }^{5}$

3 D. Hoerder, Cultures in Contact. World Migrations in the Second Millenium (Durham 2001), $10 \mathrm{ff}$.

4 W. Safran, 'Diasporas in modern societies: Myth of homeland and return', Diasporas 1 (1991), 83-99; idem, 'Comparing diasporas: A review essay', Diasporas 8 (1999), 255-291; I. Lilley, 'Diaspora and identity in archaeology. Moving beyond the Black Atlantic', dans L. Meskell et R.W. Preucel, éds., A Companion to Social Archaeology (Oxford 2006), 287-312. Sur ces déplacements conceptuels, voir aussi C. Moatti, 'Mobilités et circulations: approches historiographique et conceptuelle', dans L. Capdetrey et J. Zurbach, éds., Mobilités grecques: migrations, réseaux, contacts en Méditerranée de l'époque archaïque à l'époque hellénistique (Bordeaux 2012), 53-66.

5 A. Cohen, 'Cultural strategies in the organisation of trading diasporas', in C. Meillassoux, éd., L'évolution du commerce en Afrique de l'Ouest (Paris 1971), 266-281. Abner Cohen définit une trade diaspora comme "a nation of socially interdependant, but spatially dispersed community." Il distingue ainsi la 'diaspora' et l'organisation des migrants sur le lieu d'accueil: on voit bien ainsi que toute minorité ne forme pas une diaspora. Philippe Curtin, spécialiste du commerce des esclaves dans l'espace atlantique, a repris cette notion pour désigner ces communautés de marchands qui, bien que dispersés spatialement, forment une nation distincte à la fois de la société d'origine et des sociétés d'accueil où ils sont installés et où ils jouent le rôle de 'médiateurs culturels' ("cross cultural brokers"): voir P.D. Curtin, Cross-cultural Trade in World History (Cambridge 1984). 
Le Digeste confirme ce large spectre de la mobilité: il donne l'image d'une société en mouvement à de multiples échelles sans que jamais soit conceptualisée la notion de migration. Le droit saisit des situations concrètes de mobilité, la réalité des migrants: l'individu qui fait une stipulation à Rome pour donner quelque chose à Gadès $(D$. 45.1.137.2); l'affranchi qui doit suivre son patron dans sa peregrinatio pour accomplir ses jours de corvées (D. 38.1.21), la femme qui vient d'Afrique pour un procès à Rome $(D$. 33.7.27.1), l'homme qui s'établit dans le pays de sa femme (D. 31.34.3), les esclaves qui commercent au loin pour le compte de leur maître (D. 40.9.10); et tous les citoyens qui changent de domicile, ou encore les captifs, les déserteurs, les fugitifs, etc. Les migrants du Digeste peuvent être des pérégrins ou des esclaves, mais ce sont surtout des citoyens romains, hommes et femmes, qui se déplacent librement ou sous la contrainte, publiquement ou clandestinement, temporairement ou de manière prolongée. Si, à l'origine, la mobilité concernait principalement l'entrée et la sortie de la cité, elle devient sous l'empire une part importante de la vie sociale, et le droit l'encadre ou en règle les effets. C'est cette mobilité interne qui nous intéressera ici, ${ }^{6}$ à commencer par les nombreuses manières de la désigner, pour dire soit le statut de ceux qui se déplacent (incola, absens, hospes, inquilinus, fugitivus, etc.) soit le mouvement lui-même, temporaire (la peregrinatio) ou durable (la mutatio soli).

Le mouvement des hommes, que traduit le mot peregrinatio, fait rarement l'objet d'une interprétation jurisprudentielle. C'est d'abord son effet sur le lieu de départ, c'est-à-dire l'absence, qui suscite l'attention. Définie à l'origine comme le simple fait de ne pas se présenter dans la juridiction où l'on est convoqué (pour raison de maladie par exemple), l'absence finit en effet par désigner aussi, dès la fin de la République, l'éloignement géographique pour affaires, pour études ou encore pour mission publique (absentia rei publicae causa), et l'abondante interprétation juridique qui lui est consacrée sur des domaines autres que juridictionnels (le mariage des enfants, la gestion des munera, la fonction de juge, etc.), ${ }^{7}$ révèle les nouveaux problèmes que posent, en raison du développement du territoire impérial, l'administration des territoires conquis, le service de l'empereur ou encore le développement

6 Je laisse donc de côté la question de l'installation des populations allogènes à l'empire, bien analysée par Y. Modéran, 'L'établissement des barbares sur le territoire romain à l'époque impériale', in C. Moatti, éd., La mobilité des personnes en Méditerranée, de l'Antiquité à l'époque moderne. Procédures de contrôle et documents d'identification. Coll. de l'Ecole française de Rome 341 (Rome 2004), 337-397. Voir aussi A. Barbero, Barbari. Immigrati, profughi, deportati nell'Impero romano (Rome et Bari 2006).

7 L. Fanizza, L'assenza dell'accusato nei processi di età imperiale (Rome 1992). 
du commerce de longue distance. Dès le deuxième siècle avant notre ère, différentes mesures avaient été prises pour remédier à la dispersion des familles: la lex Atilia de tutela danda qui réglait, en l'absence (ou la mort supposée) d'un père, l'attribution d'un tuteur à un mineur; ${ }^{8}$ ou la lex Hostilia de furtis qui autorisa la représentation d'un captif qui était l'objet d'une actio furti ${ }^{9}$ - première étape dans la reconnaissance de la personnalité juridique du captif ou de l'absent rei publicae causa. Sous l'Empire, la protection de l'absent se trouve renforcée: les sources insistent sur la nécessité du procurator, ${ }^{10}$ dont Cicéron disait, dans le pro Caecina, qu'il est c'est celui qui, "administrant tous les biens d'un citoyen qui n'est pas en Italie ou est absent pour le service de la république, est en quelque sorte le maître de ses biens et le représentant de tous les droits d'un autre"11; et lédit du préteur consolide la couverture juridique des actes accomplis en vue de la défense d'un absent ${ }^{12}$ ou pour la gestion de ses biens par autrui (l'édit de negotiis gestis), ${ }^{13}$ couverture qui valait aussi bien pour le procurateur que pour l'absent. Gaius donnait la raison de ces mesures prétoriennes en insistant sur les risques et les incertitudes de l'absence: ${ }^{14}$

8 La loi stipulait que, si l'enfant résidait à Rome ou en Italie, le préteur et une majorité de tribuns de la plèbe devaient lui donner un tuteur; plus tard, les lois Iulia et Titia, d'époque augustéenne, conférèrent cette charge au gouverneur de province pour les enfants résidant en province. Cf. Gai. Instit. 1.185-186; et 187: Ab hostibus quoque tutore capto ex his legibus tutor peti debet; qui desinit tutor esse, si is, qui captus est, in civitatem reversus fuerit: Nam reversus recipit tutelam iure postliminii, "Si le tuteur est prisonnier de guerre, ces lois obligent aussi d'en réclamer un autre, lequel cesse ses fonctions au retour du premier dans la cité; car celui qui est rentré reprend la tutelle en vertu du ius postliminii."; FIRA 3. 25; lex Urso. 109 (Roman Statutes, ed. M. Crawford, London, 200o, n. 25) et lex Salp. 29 (cIL 2. 1963; FIRA 1. p. 202). Voir M. Kaser, Das römische Privatrecht (Münich 1955), 302-303; aussi J.A. Crook, Law and Life of Rome, 90 BC-AD 212 (Ithaca et New York 1987, 2nd ed.), 114. Just. Instit. 4.10.pr. D'autres lois ont suivi: voir H.J. Wolff, 'The lex Cornelia de captivis and the Roman law of succession', Tijdschrift voor Rechtsgeschiedenis / Revue d'Histoire du Droit / The Legal History Review 17.2 (1936), 136-183.

10 L'absence devient une institution, tout comme le procurator avec un mandat précis: cf. F. Serrao, Il procurator (Milan 1947), 3 ff.; O. Paperi, 'Considerazioni sull'origine del procurator ad litem', Labeo 48 (2002), 1, 37-71.

11 Cic. Caec. 20.57: is qui legitime procurator dicitur omnium rerum eius qui in Italia non sit absitve rei publicae causa quasi quidam paene dominus, hoc est alieni iuris vicarius.

12 Une évolution dont témoigne aussi la lex Irnitana Lxxxiv (J. González Fernández, CILA, II, 4, n. 1201).

13 D. $3.5 \cdot 3$ pr. (Ulp.10 ad ed).

14 D. $44 \cdot 7 \cdot 5$ pr. (Gaius, 3 aureorum). 
id ita receptum est, quia plerumque homines eo animo peregre proficiscuntur quasi statim redituri nec ob id ulli curam negotiorum suorum mandant, deinde novis causis intervenientibus ex necessitate diutius absunt : quorum negotia disperire iniquum erat, quae sane disperirent, si vel is qui obtulisset se negotiis gerundis nullam habiturus esset actionem de eo quod utiliter de suo impendisset vel is, cuius gesta essent, adversus eum qui invasisset negotia eius, nullo iure agere posset.

la plupart du temps des hommes partent en voyage dans l'idée de revenir aussitôt et pour cette raison ils ne prennent pas soin de confier leurs affaires à quelqu'un; mais ensuite, pour des raisons de nécessité extérieure ils sont absents plus longtemps: et il serait contraire à l'équité que leurs affaires dépérissent et elles dépériraient sans doute si celui qui s'offre pour gérer les affaires ne pouvait disposer d'aucune action au sujet de ce qu'il a dépensé sur ses deniers et si celui dont les affaires ont été gérées ne pouvait avoir aucun recours contre celui qui s'est emparé de ses affaires.

Un premier paradoxe apparaît cependant: tout en prenant en compte la mobilité croissante, le système judiciaire romain est longtemps resté fondé sur la disponibilité physique du citoyen, seule garante de sa bonne foi. Et si la protection de l'absent s'accrut, les conditions d'une juste absence furent de plus en plus contrôlées, comme si derrière l'absence on traquait toujours la fraude..$^{15}$

De la peregrinatio aussi relevaient certaines catégories définies par rapport au lieu d'accueil: consistentes, par exemple, désignait les gens qui séjournaient dans un endroit qui n'était ni leur origo ni leur domicile officiel; ${ }^{16}$ qui commorantur s'appliquait dans le même esprit aux étudiants, artisans, ${ }^{17}$ athlètes ou acteurs qui vivaient loin de leur patrie, ${ }^{18}$ et qui negotiantur à "ceux qui ont

15 Sur ce point, voir C. Moatti, 'Le traitement de l'absence dans le droit romain', in C. Moatti, W. Kaiser et Chr. Pébarthe, éds., Le monde de l'itinérance en Méditerranée, de l'Antiquité à l'époque moderne. Procédures de contrôle et d'identification (Bordeaux 2009), 321-353.

16 Par exemple D. 50.1. 17. 6 (Papinien 1 responsorum); et CIL 3. 5212: T. Varrio Clementi Procuratoriprovinciarum ... cives Romani [ex] Italia et aliis provinciis in Raetia consistentes.

17 C. 10.66. 1 (2 août 337): artifices artium (...) per singulas civitates morantes (=C.Th. 13.4.2).

18 Sur le statut des acteurs et mimes, cf. B. Shaw, 'Rebels and outsiders', in A.K. Bowman, P. Garnsey and D. Rathbone, éds., The Cambridge Ancient History XI (Cambridge 2000), 361-403: 390 ff. L'expression qui commorantur se retrouve sous l'Antiquité tardive, par exemple, dans la constitution de Dioclétien et Maximien ( $C$. 10.40 (39) 3: qui in territorio alicuius civitatis commorantur [...]) ou la constitution de Justinien (Nov. 8o, 9) où l'empereur s'inquiète du passage de gens, trop nombreux, qui n'ont rien à faire à Constantinople: 
une boutique, des entrepôts, des tavernes, des affaires" dans une cité qui n'est pas la leur. ${ }^{19} \mathrm{Ce}$ qui unifiait ces catégories, attestées par l'épigraphie comme par la littérature juridique, c'était la résidence de fait. Telle était la situation des Romains qui à l'époque républicaine vivaient hors d'Italie, et formaient des conventus: ils n'avaient, aux yeux des autorités, qu'un domicile de passage dans les régions dites 'transmarines', ou 'au-delà de l'Italie'; en revanche, le pouvoir central s'y intéressait et les identifiait de loin à travers ces formules stéréotypées par lesquelles ils s'auto-identifiaient. ${ }^{20}$

D'autres termes traduisent enfin le simple mouvement: hospes, par exemple, qui dans les inscriptions désigne le plus souvent l'hôte public, c'està-dire l'étranger de passage, prend, dans le Digeste, dans les sources littéraires d'époque impériale ${ }^{21}$ et dans certaines sources épigraphiques, ${ }^{22}$ le sens de citoyen de passage. "[U]n hôte n' 'habite' pas [quelque part], mais y est seulement accueilli $[\ldots]$. Il y a autant de différence en effet entre un habitant et un hôte qu'entre celui qui a son domicile quelque part et celui qui voyage."23 Le mot a donc subi sous l'empire un déplacement, en étant appliqué à des situations internes au droit romain et en perdant sa valeur statutaire. Il est parfois simplement l'équivalent de viator.

Comme hospes, peregrinus a changé de sens au cours des siècles. Après l'édit de Caracalla, il ne désigne plus un statut juridique, mais le citoyen qui se

qui hic vane commorantur... Pour cette période, voir les remarques de M.P. Baccari, Cittadini, popoli e comunione nella legislazione dei secoli IV-VI (Torino 1996), $111 \mathrm{ff}$.

19 D. 5.1.19.2 (Ulp. 6 o edict.): at si quo constitit, non dico iure domicilii sed tabernulam pergulam horreum armarium officinam conduxit ibique distraxit egit, defendere se eo loci debebit. Voir aussi: D. 50.1.17.11 (Papin.1 respons.).

20 Voir par exemple W. Van Andringa, 'Cités et communautés d'expatriés installées dans le monde romain: le cas de cives Romani consistentes', in N. Belayche et S. Mimouni, éds., Les communautés religieuses dans le monde gréco-romain: essais de définition (Turnhout 2003), 50-65.

21 Voir Petr. Sat. 95 bis; Mart. 3.5; Apul. Met. 1.17. Voir aussi les remarques de T. Kleberg, Hôtels, restaurants et cabarets dans l'antiquité romaine (Almquist 1957), 11-14.

22 Cf. par exemple cIL 6. 2357.

23 D. 9.3.1.9 (Ulp.lib. 23 ad ed.). S'interrogeant sur le sens de habitare dans l'édit du préteur relatif à la responsabilité civile de ceux qui "habitent" un édifice (Habitare autem dicimus vel in suo vel in conducto vel in gratuito, "On emploie le terme habitare pour désigner le fait d'habiter dans sa propre maison, dans un logement de location ou dans un logement gratuit"), Ulpien poursuit donc: Hospes plane non tenebitur quia non ibi habitat sed tantisper hospitatus [...] Multum interest inter habitatorem et hospitem, quantum interest inter domicilium habentem et peregrinantem. Isidore de Séville de même distingue, par la durée du séjour, les catégories d'advena-incola et d'inquilinus (Orig. 9.4.37). 
trouve à Rome sans y être né (par opposition aux indigenae) ${ }^{24}$ ou sans y avoir son domicile légal: les peregrini sont, par exemple, les travailleurs saisonniers, que le préfet de la Ville Symmaque expulse lors de la disette de $384 .{ }^{25}$ Le mot désigne aussi celui qui se trouve dans une province où il ne réside pas habituellement. ${ }^{26}$ Peregrinus devient donc à la fin du troisième siècle le mot latin le plus exact pour désigner le 'citoyen de passage'.

La deuxième forme de mobilité, la mutatio soli, fut d'abord une catégorie externe du droit romain: déplacer toutes ses affaires dans une autre cité entrânait un changement de citoyenneté, une mutatio civitatis. C'était le cas des nouveaux citoyens qui venaient résider à Rome pour exercer leurs droits ou des exilés qui, accueillis dans une autre cité, perdaient la citoyenneté romaine. Cette situation commença à changer à la fin du deuxième siècle. La loi judiciaire épigraphique d'époque gracquienne à la fois permit l'attribution de la citoyenneté romaine sans exiger de changement de résidence, ${ }^{27}$ et valorisa le domicile romain. ${ }^{28}$ La mutatio soli devint donc une catégorie interne du droit pour désigner le changement de domicile du citoyen romain et non plus seulement celui de citoyenneté.

Après la guerre sociale, ce déplacement se confirme avec l'émergence de la notion d'origo, qui désigne la cité à travers laquelle un Italien a reçu la citoyenneté romaine (ce qui conduit à la dissociation entre citoyenneté, appartenance

24 Voir par exemple C.Th. 6. 37.1 (364).

25 Voir Ambros. Off. 3.7. 44-52. Sur la crise de 383, voir L. Cracco Ruggini, 'Fame laborasse Italiam: una nuova testimonianza sulla carestia del 383 d.C.', Athenaeum, fasc. spec. In onore di P. Fraccaro (1976), 83-98.

26 C.Th. 8.1.9, AD 365. Sur l'évolution du terme, voir Baccari 1996, op. cit. (n. 18),117 ff.

27 Lex repetundarum, 1l.76-78 (M.H. Crawford, Roman Statutes I (London 1996) no. 1): en cas de succès dans un procès de repetundis, l'accusateur non-citoyen pouvait recevoir s'il le souhaitait le statut de citoyen romain, sans avoir à quitter sa cité mais l'absence de résidence romaine l'empêchait d'accéder à certaines charges; les deux clauses sont donc liées (voir la note suivante). Dans le même texte, la possibilité particulière faite aux Latins n'ayant pas revêtu de magistratures d'obtenir, à la place de la citoyenneté, les seules provocatio et immunité militaire (vacatio militum) laisse penser que dès cette époque les Latins ayant exercé une magistrature pouvaient accéder à la citoyenneté. Selon Tibiletti, ce privilège fut accordé en 124 aux lendemains de la révolte de Frégelles: G. Tibiletti, 'La politica delle colonie e città latine nella guerra sociale', Rendiconti. Instituto Lombardo, Accademia di Scienze e Lettere 86 (1953), 54-58; voir aussi la discussion dans D. Kremer, Ius Latinum. Le concept de droit latin sous la République et l'Empire (Paris 2006), $114 \mathrm{ff}$.

28 Ibidem, ligne 13: sont exclus de la fonction de juges, notamment, ceux qui n'ont pas de domicile romain: queiue in urbem Romam propiusue $u[$ rbem Romam p(assus) m(ille) domicilium non habeat.... 
locale et domicile); ${ }^{29}$ avec l'accès à la citoyenneté romaine par la gestion de magistratures locales, qui transforme définitivement les cités latines en 'communautés mixtes', ${ }^{30}$ et, à la fin du siècle, avec le cumul possible des citoyennetés en dehors de l'Italie; ${ }^{31}$ enfin avec la reconnaissance d'un domicile légal hors d'Italie, sans doute à la faveur de la colonisation en dehors de l'Italie.

Toutes ces questions ne firent pas l'objet d'une politique systématique et cohérente, mais plutôt de mesures ponctuelles ou d'une interprétation juridique qui tentait de s'adapter aux nouvelles réalités du monde romain. Un responsum d'Alfenus Varus, juriste de la fin de la République, montre bien les tâtonnements de la doctrine. Discutant une clause de la lex censoria portus de Sicile, selon laquelle ceux qui transportent des biens pour leur usage dans leur domus ne paient pas de taxes, il se demandait ce qu'on devait entendre par domus, le domicile légal: ${ }^{32}$

Igitur quaeri soleret, utrum, ubi quisque habitaret sive in provincia sive in Italia, an dumtaxat in sua cuiusque patria domus esse recte dicetur. Sed de ea re constitutum esse eam domum unicuique nostrum debere existimari, ubi quisque sedes et tabulas haberet suarumque rerum constitutionem fecisset.

Ainsi la question se pose de savoir s'il est légitime de parler de domus pour définir un lieu où un homme habite, que ce soit en Italie ou en province, ou si c'est seulement là où se trouve sa patrie. Dans cette affaire, il fut décidé que l'on doit considérer comme notre domus le lieu où chacun a sa résidence, garde ses comptes privés et tient ses affaires.

29 Y. Thomas, Origine et commune patrie: étude de droit public romain (89 av. J-C-212 $a p . J-C$ ), Coll. école française de Rome 221 (Rome 1996); sur le domicile, voir O. Licandro, Domicilium habere. Persona e territorio nella disciplina del domicilio romano (Turin 2004); C. Moatti, 'Mobility and identity between the second and the fourth centuries: the 'cosmopolitization' of the identities in the Roman Empire', in C. Rapp and H.A. Drake, éds., The City in the Classical and post-Classical World. Changing Contexts of Power and Identity (Cambridge 2014), 130-152.

$30 \quad$ Selon l'heureuse expression de Kremer 2006, op. cit. (n. 27), 116.

31 Tel est le cas pour le navarque Séleukos de Rhosos en 36 av. J.C., gratifié par Octavien de la citoyenneté, dans des conditions qui lui permettent toutefois d'être recensé in absentia, de choisir sa juridiction, de recevoir magistratures et distinctions locales et de garder dans sa cité tous ses biens. Voir les travaux récents de A. Raggi, 'The epigraphic dossier of Seleucus of Rhosus: a revised edition', Zeitschrift für Papyrologie und Epigraphik 147 (2004), 123-138= SEG 54, 1625 . 
Pour Alfenus, le droit devait donc tenir compte de la situation concrète du citoyen, de l'endroit où ce dernier habitait effectivement, que ce fût en Italie ou au-delà. Mais d'autres interprétations pouvaient valoir, conformément à la tradition qui ne reconnaissait de domicile légal qu'en Italie, dans la cité d'origine.

Bien d'autres questions relatives au domicile suscitèrent d'importantes controverses entre les juristes: par exemple était-il possible d'avoir plusieurs domiciles ou bien d'être sans domicile? La discussion continua sous l'Empire au moins jusqu'au troisième siècle. ${ }^{33}$ Paul discute ainsi la réponse du juriste augustéen Labéon: ${ }^{34}$

Labeo indicat eum, qui pluribus locis ex aequo negotietur, nusquam domicilium habere: quosdam autem dicere refert pluribus locis eum incolam esse, aut domicilium habere: quod verius est.

Labéon tient que celui qui fait des affaires dans différents endroits de manière équivalente n'a de domicile nulle part; il rapporte toutefois que selon certains cette personne est un incola ou a un domicile dans plusieurs endroits; et c'est plus près de la vérité.

Labéon fait donc la distinction entre le domicile légal et le lieu où on fait des affaires, ce qui aide à distinguer la mobilité temporaire et le changement de résidence; et surtout, pour lui, l'origo compte plus que le domicile. ${ }^{35}$ Pour Paul et d'autres, au contraire, un citoyen pouvait avoir plusieurs domiciles, une situation qui était d'ailleurs reconnue en Italie à la fin de la République, comme le montre la Tabula Heracleensis. ${ }^{36}$ Ces controverses montrent en tout cas que la question du domicile légal et donc le statut des incolae, ces citoyens

33 Moatti 2014, op. cit. (n. 29).

34 D. 50.1.5 (Paulus 45 Ed.).

35 Licandro 2004, op. cit. (n. 29), 204.

36 Tab. Heracl. lin. 157 (FIRA I², n. 13 = M. Crawford, Roman Statutes, I (Londres 1996), no. 24, 355-91): Qui pluribus in municipiis colonis praefecturis domicilium habebit, et is Romae census erit, quo magis / in municipio colonia praefectura h(ac)l(ege) censeatur, eius h.l. n(ihilum) $r$ (ogatur), "Qui a un domicile dans plus d'un municipium, colonie ou préfecture et aura été enregistré à Rome, il n'y a rien dans cette loi qui l'oblige à être enregistré dans un municipe, une colonie ou une préfecture conformément à cette loi." Ce document a été daté entre 78 et 45, mais on s'entend à dire qu'il s'agit d'un document d'époque césarienne. La tabula montre aussi que les résidents étrangers étaient enregistrés durant le census (voir C. Nicolet, 'La table d'Héraclée et les origines du cadastre romain', in C. Pietri, éd., L'Urbs. Espace urbain et histoire (Ier siècle avant J.C.-IIIe siècle après J.C.). Coll. de l'Ecole française de Rome 341 (Rome 1987), 1-25.) On peut se demander toutefois si le cas de ceux 
romains qui résidaient officiellement dans une autre cité que la leur, restaient à définir au début du premier siècle de notre ère. ${ }^{37}$

Au cours de l'empire, deux figures deviennent donc paradigmatiques de la mobilité humaine et font l'objet d'une importante interprétation juridique: l'incola qui va permettre de penser toute forme de migration interne durable ainsi la femme qui suit le domicile de son mari est désignée comme "semblable à un incola" -;38 et l'absens qui permet de penser les effets de la mobilité temporaire. Deux catégories qui aident également, implicitement, à réfléchir sur des statuts incertains, par exemple celui des étudiants: alors qu'ils pouvaient résider à Rome très longtemps, pouvaient-ils revendiquer le domicile romain? ${ }^{39}$ Ou celui des hommes d'affaires qui, nous venons de le voir, possédaient des biens dans différentes parties de l'empire. L'enjeu était double: le domicile et l'origo impliquaient des devoirs, les munera, auxquels certains voulaient échapper, ou au contraire des privilèges, dont certains, tels les étudiants à Rome, cherchaient à bénéficier.

Cette casuistique reflète une partie des problèmes que posaient la rupture de la 'communauté spatiale' et le cumul de multiples affiliations. Plus généralement, les juristes ont pris de plus en plus en compte la spatialité de l'empire, et son double impact, temporel (délais, retard, durée de l'absence) ou territorial (pensons aux indications relatives aux itinéraires officiels ou à la délimitation des pouvoirs): ${ }^{40}$ ce sont autant d'indices du développement de la mobilité au cours des siècles.

qui ont de multiples domiciles ne concerne pas plus précisément les non-Italiens qui, tel Archias, avaient été enregistrés dans plusieurs cités.

Le mot incola définit deux catégories de personnes: les citoyens qui ont leur domicile légal dans une autre cité que la leur - l'équivalent des métoikoi grecs; et les habitants d'un lieu qui sont restés sur place après la fondation d'une colonie sans le statut de citoyen (l'équivalent des paroikoi du monde grec). Nous ne prenons en considération ici que la première catégorie. Sur cette question, voir L. Gagliardi, Mobilità e integrazione delle persone nei centri cittadini romani. Aspetti giuridici. I. La classificazione degli incolae (Milan 2006) $46 \mathrm{ff}$., 11off., $329 \mathrm{ff} .$. Sur le vocabulaire grec, voir A.D. Rizakis, 'Incolae - paroikoi: population et communautés dépendantes dans les cités et les colonies romaines d'Orient', Revue des Études Anciennes 100 (1998), 599-617; F. Papazoglu, Laoi et Paroikoi. Recherches sur la structure de la société hellénistique (Belgrade 1997), 201ff., 231-2.

$3^{8} \quad$ D. $5^{0.1 \cdot 38.3 .}$

39 C. Moatti, 'Le contrôle des gens de passage à Rome aux trois premiers siècles de notre ère', in C. Moatti et W. Kaiser, éds., Gens de passage dans les villes méditerranéennes, de l'Antiquité à l'époque moderne. Procédures de contrôle et d'identification (Paris 2007), 79-101: $85-86$. 
Pour autant les autorités romaines ont-elles défini des politiques migratoires? La question semble anachronique mais il s'agit ici de rendre compte d'une production abondante de normes, qui relève de deux logiques, la protection et le contrôle.

Les anciens étaient conscients de la précarité du migrant: précarité sur les routes, bien sûr, mais aussi dans les lieux d'étapes (d'où les actions spéciales reconnues par les préteurs contre les aubergistes malveillants), ${ }^{41}$ ou dans les lieux d'arrivée, où le migrant pouvait voir ses biens et sa personne saisis, en temps de paix comme en temps de guerre. Les mesures de protection que l'on trouve en Grèce (l'asyleia notamment) ${ }^{42}$ existaient aussi à Rome et forment une sorte de 'droit négocié', même si elles n'ont jamais constitué un vrai corps de doctrine unifié.

De négociation il est question par exemple dans les traités qui encadrent les échanges économiques entre certains étrangers et les Romains, tels les traités romano-carthaginois, ${ }^{43}$ mais aussi les multiples accords économiques entre Rome et les tribus germaniques, ou entre Rome et la Perse. ${ }^{44}$ Ces conventions qui définissaient notamment les lieux de commerce légal permettaient d'assurer la sécurité des échanges, de rapporter des bénéfices douaniers tout en encadrant le passage de certaines marchandises. Fiscalité, sécurité et liberté de circuler y apparaissent étroitement liées. On peut faire aussi l'hypothèse que les négociations sur les privilèges commerciaux ont fixé spatialement des formes de réglementation qui avaient été longtemps personnelles: ainsi, la notion de commercium, qui définissait à l'origine un droit d'user du ius civile (pour les Latins par exemple) puis tout simplement le droit de vendre et d'acheter, a fini par désigner aussi un lieu de commerce légal entre Romains

41 Par exemple D. 4.9.1.pr.-1 (Ulp. 14 edict.); D. 4.9.3.1 (Ulp. 13 edict.).

42 Voir par exemple B. Bravo, 'Sulan. Représailles et justice privée contre les étrangers dans les cités grecques', Annali della Scuola Normale Superiore di Pisa 10 (1980-1981), 675-987; A. Bresson, 'L'entrée dans les ports en Grèce ancienne', in C. Moatti et W. Kaiser, éds., Gens de passage dans les villes méditerranéennes, de l'Antiquité à l'époque moderne. Procédures de contrôle et d'identification (Paris 2007), 37-78.

43 B. Scardigli, I trattati romano-cartaginesi. Introduzione, traduzione, edizione critica, commentario (Pise 1991); A. Bresson, 'Les traités romano-carthaginois', in C. Moatti, éd., La mobilité des personnes en Méditerranée, de l'Antiquité à l'époque moderne. Procédures de contrôle et documents d'identification. Coll. de l'Ecole française de Rome 341 (Rome 2004), 649-676.

44 C. Moatti, 'Le contrôle de la mobilité des personnes dans l'empire romain', Mélanges de l'École française de Rome. Antiquité 112 (2000), 925-958; voir n. 45. 
et étrangers à l'empire. ${ }^{45}$ La régulation des migrations a ainsi contribué à la territorialisation de l'empire.

Parmi les conventions, il faut aussi faire une place aux accords d'amitié ou d'hospitalité publique qui sont en partie des accords d'asyleia. Selon le juriste Pomponius, un Romain pouvait être 'saisi' en temps de paix dans une cité qui n'avait pas d'accord d'amitié ou d'hospitalité avec Rome: à ce 'captif', assimilé à un prisonnier de guerre, il était juste que l'on reconnût le droit de retour, ou ius postliminii. ${ }^{46}$ Inversement, confirmait le juriste Proculus, les peuples libres (les peuples clients de Rome par exemple) et ceux avec lesquels existe un traité "conservent leur liberté et leur droit de propriété chez nous, comme nous chez eux". ${ }^{47}$ C'est en partie ce que garantissait le traité d'amitié entre Rome et le koinon des Lyciens en 46 avant notre ère, qui protégeait non seulement les Lyciens contre toute saisie illégale de corps et de biens (par exemple contre la violence des hommes d'affaires romains et des publicains qui s'emparaient des biens ou des personnes des débiteurs pour se dédommager directement), mais aussi contre toute saisie de gages dans un contexte judiciaire: 48

\section{32-34}

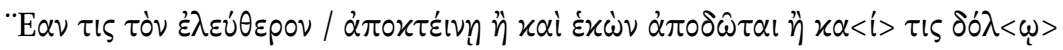

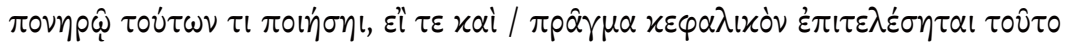

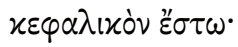

Si quelqu'un tue un homme libre, ou s'il le vend de propos délibéré, ou si quelqu'un commet une infraction similaire par ruse ou tromperie, et si un acte (passible de la peine) capital(e) est perpétré, tout cela sera (considéré comme passible d'un procès en peine) capital(e).

11. $43-45$

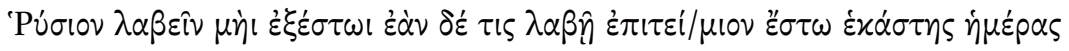

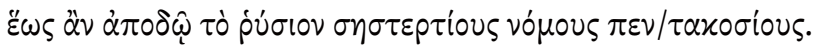

45 C. Moatti, 'La mobilité négociée dans l'Empire romain tardif: le cas des marchands étrangers', in Le relazioni internazionalinell'alto medioevo. Settimane di studio della Fondazione Centro italiano di studi sull'alto Medioevo, 58, Spoleto, 8-12 aprile 2010 (Spolète 2011), 159-188.

$46 \quad$ D. $49 \cdot 15 \cdot 5$ (Pomponius 37 ad Q. Mucium).

47 D. 49.15 .7 (Proculus 8 epist.): illi apud nos et libertatem suam et dominium rerum suarum aeque atque apud se retineant et eadem nobis apud eos contingant; D. 49.15.12, pr. (Tryphonianus 4 disput.).

48 Sur ce point, nous suivons l'interprétation de P. Sanchez, 'La convention judiciaire dans le traité conclu entre Rome et les Lyciens (P. Schøyen I 25)', Chiron 37 (2007), 363-381: 373-74. 
Il est interdit de saisir des gages. Si quelqu'un en saisit, il payera une amende de 500 sesterces par jour jusqu'à ce qu'il rende les gages. ${ }^{49}$

Ce traité réglait aussi l'accès aux tribunaux pour les ressortissants des deux communautés, selon la règle du forum rei: dans un procès capital intenté en Lycie, si l'accusé était un citoyen romain, il devait être jugé à Rome, un Lycien en Lycie; dans un procès civil ou pénal non capital, le citoyen romain accusé devait être jugé par le gouverneur romain voisin, le Lycien par un Lycien. ${ }^{50} \mathrm{La}$ politique romaine en matière de protection judiciaire des citoyens résidant chez des alliés ou en province n'a pas fait l'objet de normes générales et variait selon le statut des territoires concernés: dans les cités libres, par exemple, les Romains avaient l'obligation de passer par les tribunaux locaux pour les affaires civiles, comme le montrent les décrets de Colophon ou le sénatus-consulte d'époque syllanienne conservé dans une inscription augustéenne concernant Chios. ${ }^{51}$ Pour autant, cette politique et les privilèges judiciaires des Romains apparaissent de manière cohérente dans les chartes municipales de la partie

$49 A E$ 2005, $1487=S E G 55.1452$, ll.43-45; le traité a été publié par S. Mitchell, 'The treaty between Rome and Lycia (MS 2070)', in R. Pintaudi, éd., Papyri Graecae Schøyen I, Papyrologica Florentina 35 (Firenze 2005), 163-250.

Pour le reste de la convention, Sanchez 2007, op. cit. (n. 48) montre que la convention ne concernait que les affaires se déroulant en Lycie. Ce n'était donc pas un traité d'extradition équitable, contrairement à ce que pensait Mitchell 2005, op. cit. (n. 49): si un Lycien était accusé à Rome, c'est en effet à Rome et devant le préteur pérégrin qu'il devait être jugé.

$5^{1}$ Sur toute cette question, voir J. Fournier, Entre tutelle romaine et autonomie civique. L'administration judiciaire dans les provinces hellénophones de l'Empire romain (129 av. J.C.235 apr.JC). Bibliothèque des écoles françaises d'Athènes et de Rome 341 (Athènes 2010); idem, 'Rome et l'administration judiciaire provinciale', in F. Hurlet, éd., Rome et l'Occident (IIe s. av. - IIe s. apr. J.-C.). Gouverner l'Empire (Rennes 2009), 207-227. Sur les cités libres, le témoignage de Cicéron (Flac. 29.71) est intéressant, qui demande à un certain Decianus pourquoi il fait des affaires à Apollonis (cité libre) et pas à "Pergame, Smyrne, Tralles, où les citoyens romains sont en grand nombre et où la justice est rendue par nos magistrats", Pergami, Smyrnae, Trallibus, ubi et multi cives Romani sunt et ius a nostro magistratu dicitur. Selon J.L. Ferrary, 'Le statut des cités libres dans l'empire romain à la lumière des inscriptions de Claros', Comptes Rendus. Académie des Inscriptions et belles-lettres 135 (1991), 557-577 ce droit ne fut toutefois pas uniformément appliqué: d'où les nombreuses ambassades pour le faire respecter. La présence de Romains comme groupe pouvait en effet constituer une menace contre la liberté des cités. Il n'est pas sûr qu'il faille pour autant conclure avec lui que l'on trouvait plutôt les citoyens romains là où les gouverneurs pouvaient intervenir, c'est-à-dire dans les cités où le gouverneur tenait ses assises (Ephèse ou Pergame par exemple). 
occidentale de l'empire ou dans les nombreux décrets, édits, rescrits émis en réaction à des pétitions ou à des troubles, tels ceux provoqués par des provinciaux contre des Romains résidents accusés de rapines et d'extorsions. ${ }^{52}$

Tous ces dispositifs fondés sur la négociation permettent de définir l'espace impérial comme un territoire 'normatif' discontinu, constitué par les multiples accords entre le peuple romain et les autres peuples, cités, nations, soumis ou non. Grâce à ces accords, la liberté de circuler et de conserver ses biens devait être préservée, du moins théoriquement.

Cette dimension négociée de la mobilité concernait bien d'autres formes de mobilité que nous ne pouvons aborder dans le cadre de cet article: la restitution des prisonniers, ${ }^{53}$ l'échange d'otages, l'extradition des déserteurs, l'accueil des chefs étrangers qui recevaient des sauf-conduits impériaux; ${ }^{54}$ ou encore l'installation de communautés entières, une pratique qui fut largement mâ̂trisée jusqu'au quatrième siècle de notre ère. ${ }^{55}$ Toutes ces mesures étaient très encadrées, comme en témoignent les sources de Polybe à Zosime; le récit d'Ammien Marcellin rapportant l'accueil désastreux fait aux Goths Tervinges, fuyant les Huns et accueillis par Valens en 376, révèle à la fois l'implication de l'administration romaine mobilisée pour ces manœuvres, et ses dysfonctionnements, notamment en raison de la corruption dans le rang des officiels. ${ }^{56}$

Ce dernier exemple fait apparaître l'autre logique de ces politiques migratoires: celle du contrôle. Entendons par ce terme à la fois la régulation directe, et les normes dont l'effet indirect fut de limiter ou au contraire de faciliter la mobilité.

Deux constatations s'imposent: d'une part, la grande diversité des situations et l'absence de règlements généraux, qu'il s'agisse de l'entrée dans les villes, de la mobilité à l'intérieur de l'empire, ou même du passage des frontières; ${ }^{57}$

52 Tel fut le cas à Cyzique (Tac. Ann. 4.36.2; Suet. Tib. 37.7; C.D. 57.24.6), à Rhodes (C.D. 6o.24.4), ou encore à Colophon. Voir Ferrary 1991, op. cit. (n. 51).

53 Zosime au livre 3.3-4 décrit par exemple la façon dont Julien négocie la paix avec les Alamans en 357-8, dressant la liste des Gaulois faits prisonniers l'année précédente et forçant les ennemis à les restituer jusqu'au dernier.

Sur ces aspects les textes sont innombrables: voir par exemple RGDA 32; l'inscription de Tiberius Plautius Silvanus Aelianus, gouverneur de Mésie de 61 à 66 ( CIL 14. $3608=I L S$ 986, ll.9-26); ou Tac. Ann. 2.63 (l'accueil de Maroboduus, chef germain).

56 Amm. 31.4-5.

57 Voir l'étude de A.E. Lee, Information and Frontiers. Roman Foreign Relations in Late Antiquity (Cambridge 1993), 56, 66 qui souligne la coexistence entre une perméabilité des frontières de l'Empire et le sentiment de la frontière. Sans doute les migrants saventils qu'ils passent d'un territoire à un autre (par exemple de la Perse à Rome) ou d'une 
d'autre part, le contraste entre une apparente fluidité et la multiplicité des règles. Ainsi, les anciens distinguaient, comme nous le faisons aujourd'hui, la mobilité légale et la mobilité illégale, mais le contrôle portait sur des catégories de personnes, non sur le territoire. Aussi de multiples logiques pouvaient-elles coexister: maintien de l'ordre public, interdictions de nature symbolique (interdiction à un homme taxé d'infamie de résider à Rome, par exemple), contrôle fiscal, attestation de privilèges, etc. Il faut toutefois distinguer deux niveaux de régulation: la cité et l'empire.

Le régime civique imposait un certain contrôle sur le départ des citoyens dans chacune de ses trois dimensions: le voyage ou peregrinatio, le changement de citoyenneté, et le changement de domicile.

A la liberté de la peregrinatio, il existait de sérieuses limites: la nécessité pour les citoyens de revenir à chaque census, l'obligation de leur présence physique pour l'accomplissement d'un grand nombre d'actes. Cette liberté avait aussi des limites statutaires, les plus contrôlés étant sans doute les membres de l'élite dirigeante: pensons aux nombreuses mesures prises pour limiter l'éloignement des sénateurs, pour empêcher les sénateurs d'origine provinciale de retourner trop souvent dans leur cité d'origine..$^{58}$ Il faut attendre Caracalla, pour que ces derniers se voient reconnaître un double domicile, mais c'est seulement dans l'antiquité tardive qu'ils reçurent l'autorisation de résider où ils le souhaitaient. Toutefois, les restrictions restaient importantes dans la partie orientale de l'empire. ${ }^{59}$

Des limitations existaient de même pour la mutatio soli. Si dans la Rome républicaine, le citoyen était libre de quitter sa patrie (mais en partant il perdait sa citoyenneté), les cités italiques, qui avaient des obligations militaires

province à une autre $(D .1 .18 .3 ; D .48 .15 .7 .2)$, mais il n'y a pas de contradiction, comme l'a écrit aussi Potter, entre le niveau du droit qui établit des limites, et le niveau du quotidien qui les dépasse: D.S. Potter, 'Emperors, their borders and their neighbours: the scope of imperial mandata', in D. Kennedy, éd., The Roman Army in the Near East. Journal of Roman Archaeology suppl.18 (Ann Arbor 1996), 49-66: 57 ff, où il cite Procop. Aed. 3.3.911; voir aussi S.N.C. Lieu, 'Captives, refugees and exiles: a study of cross-frontier civilian movements and contacts between Rome and Persia from Valerian to Jovian', in P. Freeman et D. Kennedy, éds., The Defence of the Roman and Byzantine East. Proceedings of a Colloquium held at the University of Sheffield in April 1968. British Archaeological Reports International series 297 (1986) 2, 485 .

$5^{8}$ Les sénateurs devaient avoir leur domicile légal à Rome, et à partir de Trajan, ils durent posséder un tiers de leurs propriétés en Italie, un pourcentage que Marc-Aurèle réduit à un quart (HA. Marc. Aur. 11.8). Voir A. Chastagnol, Le sénat romain à l'époque impériale (Paris 1992); voir aussi Moatti 200o, op. cit. (n. 44), et Eck dans ce même volume. 
et financières à l'égard de Rome, contrôlaient le départ de leurs citoyens: tel fut le cas des Latins établis à Rome au début du deuxième siècle, qui furent rapidement réclamés par leur cité d'origine sous prétexte qu'ils n'avaient pas respecté les termes de la loi locale fixant les conditions du départ. Ils étaient donc accusés d'émigration illégale, et Rome accepta de les renvoyer dans leurs cités. ${ }^{60}$ Selon Cicéron, certains traités comportaient une clause d'exception au terme de laquelle Rome s'empêchait d'octroyer la citoyenneté romaine pour éviter de dépeupler les cités signataires. ${ }^{61}$

Quant au changement de domicile, il était libre sous l'Empire, y compris pour les affranchis ou les fils de famille, et même défini dans les textes de droit comme un ius libertatis, ${ }^{62}$ avec toutefois quelques réserves, comme le rappelle le juriste Marcellus: “Il n'y aucun obstacle à changer de domicile, tant que la loi le permet." ${ }^{\prime 3}$ Non seulement en effet plusieurs catégories étaient astreintes à un domicile obligatoire (domicilium necessarium) (soldats, sénateurs, femmes mariées, relégués, etc.), ${ }^{64}$ mais le migrant devait maintenir un lien étroit avec son origo pour l'accomplissement des munera. ${ }^{65}$

A l'échelle impériale, aussi, le service de l'empereur, l'administration des provinces, l'extension du domaine du fisc ont conduit à encadrer les populations mobiles (légations, missions publiques, gens de scène, vagabonds, etc.). Les interventions impériales se sont-elles renforcées au cours de l'Empire? Le cas des grandes villes nous le laisse penser.

En dehors des barrières d'octroi, il n'a pas existé de contrôle à l'entrée ou à la sortie des grandes villes (Alexandrie constituant un cas à part). ${ }^{66} \mathrm{~A}$ Rome, la protection de la cité, la custodia urbis confiée officiellement au Préfet de la Ville

60 W. Broadhead, 'Rome and the mobility of the Latins: problems of control', in C. Moatti, éd., La mobilité des personnes en Méditerranée, de l'Antiquité à l'époque moderne. Procédures de contrôle et documents d'identification. Coll. de l'Ecole française de Rome 341 (Rome 2004), 315-335; voir aussi Kremer 2006, op. cit. (n. 27), 32 ff.

61 Cicéron cite notamment le traité avec Camerinum, avec les peuples celtes de l'Italie du Nord ou de l'arc Alpin, Cénomans, Insubres, etc. (Cic. Balb. 32); voir le commentaire de P. Sánchez, 'La clause d'exception sur l'octroi de la citoyenneté romaine dans les traités entre Rome et ses alliés (Cicéron, Pro Balbo 32)', Athenaeum 95 (2007), 215-270.

62 D. 35.1.71.2 (Papinian 17 quaest.).

63 D. 5 0.1.31 (Marc. 1 Dig.): Nihil est impedimento, quo minus quis ubi velit habeat domicilium, quod ei interdictum non sit.

64 Voir les analyses de Gagliardi 2006, op. cit. (n. 37).

65 Sur cet aspect, voir Moatti 2014, op. cit. (n. 29).

66 Gnomon de l'Idiologue (art. 64-66); P.Oxy. 1259. Sur ces documents, voir S.E. Sidebotham, Roman Economic Policy in the Erythra Thalassa, 30 B.C.-A.D. 217 (Leyde 1986), 8off.; Moatti 2000, op. cit. (n. 44). 
à partir du troisième siècle n'était pas non plus, selon les justes mots de Vitucci, "dirigée vers le monde extérieur, mais contre ceux qui à l'intérieur menaçaient l'ordre public." ${ }^{\prime 7}$ La remarque d'Apulée, selon laquelle entrer dans une grande ville est un moyen d'échapper aux poursuites grâce à l'anonymat, a donc dû être valable dans tout le monde impérial. ${ }^{68}$ Cette liberté était cependant compensée par diverses mesures visant à contrôler certaines catégories de personnes et de biens, comme c'était le cas aux frontières de l'empire lui-même: interdictions de passage (pour les déditices, les infâmes), limitations de séjour (pour les étudiants), expulsions (des philosophes, des astrologues, des juifs, etc.) furent trois moyens, aux mains du Préfet de la Ville, pour réguler les flux de population, avec des résultats qui restent cependant difficiles à évaluer. ${ }^{69}$

Dans l'antiquité tardive, l'entrée des grandes cités fit l'objet de nouvelles régulations, comme l'atteste la constitution de Valentinien qui règle les détails de la mobilité des étudiants; ou le contrôle des sacerdotales sous le règne d'Honorius: pour mettre fin aux troubles provoqués lors des jeux donnés à l'occasion de la réunion annuelle du Conseil du diocèse d'Afrique, l'empereur, qualifiant les sacerdotales païens de superflua turba, leur enjoint de quitter Carthage dans un délai de cinq jours à compter de la fin des cérémonies, sous peine d'encourir une énorme amende - et ces mesures ne concernent pas seulement les sacerdotes païens. ${ }^{70}$

Cet exemple est intéressant à plus d'un titre: il montre que l'afflux de gens extérieurs à la cité est devenu un problème; et il révèle l'apparition d'une pénalisation de l'inutilité. Inutiles sont les légations trop nombreuses auprès de l'empereur, ${ }^{71}$ inutiles aussi les séjours prolongés des provinciaux à Rome ou à Constantinople, inutiles les paysans quand ils s'éloignent de leurs champs. En 539, Justinien chercha à répondre définitivement à ce problème en créant un magistrat permanent, le quaesitor: il fut chargé, à Constantinople, d'interroger les gens de passage sur leurs intentions et de les renvoyer chez eux s'ils

67 G. Vitucci, Ricerche sulla prefettura urbi in età imperiale I-III (Roma 1956).

68 Apul. Met. 8.23.

69 Moatti 2000, op. cit. (n. 44); eadem, 'Immigration and cosmopolitanization', in P. Erdkamp, éd., The Cambridge Companion to Ancient Rome (Cambridge 2013), 77-92.

70 Valentinien: C.Th. 14.9.1 (12 mars 370); Honorius: C.Th. 16.10.20 (30 août 415). Voir A. Chastagnol, 'Sur les sacerdotales à la veille de l'invasion vandale', in A. Mastino, ed., L'Africa romana 5. Atti del V convegno di studio, Sassari 11-13 dicembre 1987 (Sassari 1988), 101-110; et S. Guédon, Le voyage dans l'Afrique romaine (Bordeaux 2010) 153 ff.

$71 \quad$ C.Th. 12.12.6, Valentinien. 
n'avaient rien à faire dans la cité. Dans la constitution impériale, la mobilité inutile est désignée comme un mediocre delictum. ${ }^{72}$

La différence avec le début de l'Empire est considérable. A l'instar de César, en effet, les premiers empereurs avaient souvent favorisé une immigration utile (médecins, professions libérales, par exemple); de même, empereurs ou gouverneurs avaient, ponctuellement, fait expulser certaines catégories de la population soit pour répondre à une crise annonaire ou à une agitation politique, soit pour les nécessités du recensement (le retour aux idia dans les décrets d'Egypte). Le P. Giessen 40 contient un de ces décrets d'expulsion et on y retrouve tous les éléments: accusation de troubler l'ordre public, inutilité, critique de l'exode rural, mais aussi liste des personnes autorisées à rester pour de bonnes raisons - "les marchands de porcs, les matelots, les fournisseurs de calamos, pour chauffer les bains, [...] ceux qui fournissent des bêtes pour les sacrifices en l'honneur de Sérapis ou pour quelque autre fête [...]", ou encore "ceux qui viennent pour admirer la brillante cité d'Alexandrie, pour profiter d'une vie civilisée, ou tous ceux qui ont à régler des affaires à Alexandrie."73 Avec les mesures des quatrième-cinquième siècles, la production normative tend, au contraire, à devenir permanente; de plus, c'est le territoire de la grande ville qu'il faut protéger contre l'afflux de migrants; enfin, l'inutilité devient un concept pénal, comme le montre aussi la politique impériale à l'égard des mendiants, et des vagabonds. ${ }^{74}$

Ces politiques répressives n'ont pas mis fin à la mobilité, mais traduisent une territorialisation de l'empire. Les contrôles aux frontières en sont d'autres preuves dont témoignent l'importante législation constantinienne sur les déserteurs et ceux qui passent dans le monde barbare (ad barbaricum

72 Nov. Const. 80; voir D. Feissel, 1995, 'Aspects de l'immigration à Constantinople d'après les épitaphes protobyzantines', in C. Mango, G. Dagron et G. Greatrex, éds., Constantinople and its Hinterland. Papers from the Twenty-Seventh Spring Symposium of Byzantine Studies, Oxford, April, 1993 (Londres 1995), 367-377; Moatti 2007, op. cit. (n. 39), 90-92.

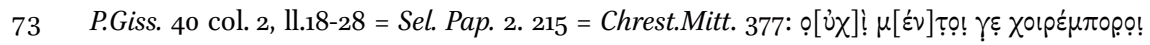

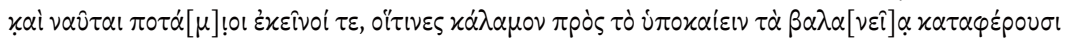

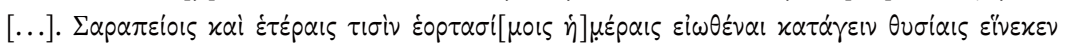

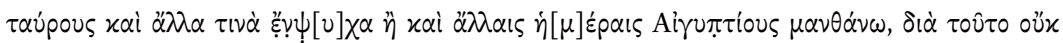

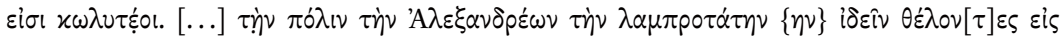

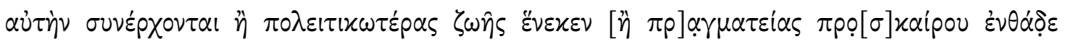

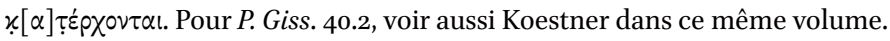

74 Voir B. Pottier, 'Contrôle et mobilisation des vagabonds et des mendiants dans l'empire romain au IVe siècle et au début du Ve siècle', in C. Moatti, W. Kaiser et Chr. Pébarthe, éds., Le monde de l'itinérance en Méditerranée, de l'Antiquité à l'époque moderne. Procédures de contrôle et d'identification (Bordeaux 2009), 203-237. 
transeuntes), ${ }^{75}$ ou encore le décret d'Anastase $1^{\text {er }}$ réglant en 501 l'organisation de la province de Cyrénaïque et ordonnant aux gardes des frontières d'empêcher les Romains de quitter l'empire: ${ }^{76}$

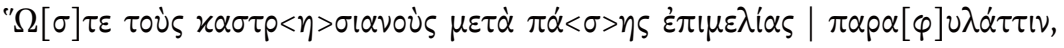

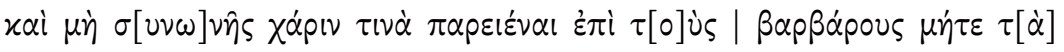

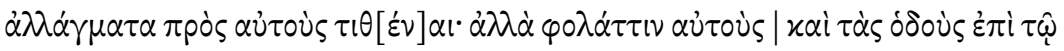

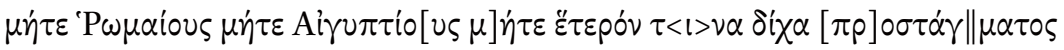

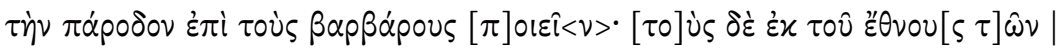

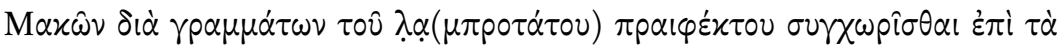
$\chi \omega{ }^{\prime} \dot{\alpha} \alpha[\Pi \varepsilon] \nu \tau \alpha \mid \pi \delta \dot{\lambda} \varepsilon \omega \varsigma \pi \alpha \rho \alpha \gamma i v \varepsilon \sigma \theta \alpha \mathrm{l}$.

Que les soldats des forteresses veillent avec toute diligence à ce que personne n'aille chez les Barbares pour des raisons commerciales, ni pour passer des contrats avec eux; qu'ils surveillent les routes, afin que ni les Romains, ni les Egyptiens, ni qui que ce soit d'autre, ne disposent sans autorisation de la libre entrée chez les Barbares; qu'en revanche, ceux qui appartiennent au peuple des Maces, s'ils sont porteurs de lettres du clarissime préfet, aient l'autorisation de se rendre dans les contrées de la Pentapole.

Ainsi le contrôle était-il exigé dans les deux sens. Et si les Maces avaient ces lettres, c'est qu'ils étaient liés à Rome par un traité qui leur accordait des saufconduits. Témoignage qu'il faut rapprocher aussi de celui d'Augustin et des ostraka de Bu Njem sur le contrôle en Tripolitaine de la main d'œuvre barbare. ${ }^{77}$

75 C. 6.1.3, Constantin.

76 SEG 9. 356 (Ptolemais), 46-54 §11 (G. Oliverio, 'Il decreto di Anastasio Primo su l'ordinamento politico militare della Cirenaica', Documenti antichi dell'Africa Italiana, Cirenaica 2, Bergame, 1936-XV, pp.135-163); voir aussi SEG 9. 414 (Teucheira-Arsinoe); 27. 1139 (Apollonia) pour d'autres fragments du même décret.

Aug. Ep. 46.1: decurioni qui limiti praeest vel tribuno solent iurare barbari, iurantes per daemones suos, qui ad deducendas bastagas pacti fuerint, vel aliqui ad servandas fruges ipsas, singuli possessores vel conductores solent ad custodiendas fruges suscipere, quasi iam fideles, epistolam decurione mittente, vel singuli transeuntes quibus necesse est per eos transire, "les barbares engagés pour la conduite des charrois et la garde des récoltes prêtent serment (de retourner chez eux?) en présence du décurion préposé au limes ou devant le tribun en jurant par leurs démons. Les propriétaires ou leurs fermiers engagent en toute sécurité les gardiens des récoltes au vu d'une lettre du décurion et les voyageurs engagent de même ceux dont les services leur sont nécessaires” (voir R. Rebuffat, 'Mobilité des personnes dans l'Afrique romaine', in C. Moatti, La mobilité des personnes en Méditerranée de 
Au-delà des conjonctures, les villes, plaques tournantes de la circulation des hommes et des biens, nécessitent la création de structures d'accueil, tels les collèges, associations, stationes. Ces structures étaient-elles contrôlées par les autorités? Quel accueil, quelle intégration y fut possible pour celui qui s'installait dans une autre ville que la sienne? Récemment Peter Bang et Taco Terpstra ont expliqué que les associations de marchands avaient pour fonction de garantir la réputation des marchands dans un empire où ni le respect des contrats ni l'exécution des décisions judiciaires n'étaient garantis par l'Etat. Les associations en quelque sorte compensaient la faiblesse de l'Etat. ${ }^{78}$ Cette conception néglige le fait que les contrats présentaient eux-mêmes des garanties (le chirographe engage notamment un grand nombre de témoins et les empereurs ont tenté de renforcer la protection matérielle de ces documents); ${ }^{79}$ et que de nombreuses actions étaient à la disposition des plaignants. Mais surtout, elle n'accorde aucune attention au rôle d'institutions médiatrices' que jouaient les associations et collèges reconnus par l'Etat et recevant une sorte de 'délégation de pouvoir'.

La lettre de Claude aux Alexandrins de 41, où l'empereur appelle au calme à la suite de pogroms menés contre la population juive, en constitue un excellent témoignage. Ce texte a souvent été cité comme l'un des nombreux documents attestant la continuité, depuis l'époque ptolémaïque, d'une politique de restriction de l'immigration juive en Egypte mais on n'a jamais remarqué que l'empereur s'adresse directement aux juifs pour leur interdire "de faire

l'Antiquité à l'Epoque moderne: procédures de contrôle et documents d'identification. Coll. de l'Ecole française de Rome 341 (Paris 2004), 155-203); cf. aussi R.G. Goodchild, 'The limes Tripolitanus II', Journal of Roman Studies 40 (1950), 30 sq, p. 31; R. Marichal, Les ostraka de Bu Njem. Supplément de Libya antica VII (Tripoli 1992), 111, rapproche ce texte d'Augustin d'un ostrakon de Bu Njem ( $\left.{ }^{\circ} 71\right)$, document porte qu', [... N] ovemb(res) introierunt / [..]. amantes ducentes asinos n(umero) iiii / ẹt egiptios n(umero) ii · ferentes lit/teras at te et Gtasazeiheme Opter servu fugitiu, "un jour d'octobre ou de novembre sont entrés à Golas des Garamantes portant des lettres pour le praepositus et conduisant 4 ânes, 2 Egyptiens et un esclave fugitif nommé Gtasazeiheme Opter"; et du document 101 où l'on trouve aussi cette notice: scias domine benisse a meos refuga Abban barbarus, "sache, seigneur, qu'est venu auprès de mes hommes un transfuge barbare Abban". Traduction de R. Marichal, p. 110 et commentaire: "nos Garamantes apportent donc peut-être une lettre d'un praepositus voisin de celui de Golas les accréditant ainsi auprès de lui”.

78 Bang 2008, op. cit. (n. 1); Terpstra 2013, op. cit. (n. 1).

79 Voir E.A. Meyer, Legitimacy and Law in the Roman World. Tabulae in Roman Belief and Practice (Cambridge 2004). 
venir ou d'admettre des juifs qui proviennent de Syrie et d'Egypte" - et qu'il désigne comme responsables des troubles. ${ }^{80}$ Les juifs accueillaient en effet leurs coreligionnaires sans en demander l'autorisation, et il en était ainsi dans toutes les grandes villes: à Rome, par exemple, cette liberté atteignit parfois des proportions jugées intolérables par les autorités, au point de provoquer des expulsions, sous Tibère en 19 ou sous Claude en 47 par exemple.

Cette fonction d'encadrement est attestée pour d'autres groupes: les stationes des cités qui étaient établies à Rome sous le contrôle des autorités, selon Suétone; ${ }^{81}$ ou encore les associations de marchands ou d'athlètes. Celle des vainqueurs sacrés aux jeux athlétiques et des athlètes œcuméniques, par exemple, disposait d'un local permanent à Rome accordé par Trajan, tout comme l'association des acteurs. ${ }^{82}$ Les associés recevaient un diploma, une sorte de document de voyage, dont le contenu nous est connu par un papyrus d'Oxyrhynchus de 274-275; ils devaient le présenter au cours de leurs déplacements pour bénéficier de l'hospitalité à laquelle ils avaient droit. ${ }^{83}$ Les inscriptions qui émanent de ces associations peuvent dès lors être interprétées en partie comme la manifestation de leur caractère public. Quel que fût leur contenu, elles faisaient avant tout foi de ce statut public. Le réel ici rejoignait le symbolique.

L’idée de 'délégation implicite' permet de comprendre le rôle de ces associations dans l'intégration de leurs membres; mais aussi de replacer les mesures prises au quatrième siècle pour contrôler les étudiants ou les marchands étrangers dans une histoire plus longue. Si le contrôle a toujours existé, ce sont les méthodes qui ont changé avec le temps: dans l'antiquité tardive elles se font plus directes.

Dans l'intégration des migrants, l'évolution du statut d'incola, de plus en plus proche de celui des cives (avec l'attribution du droit de vote, l'accès au décurionat), a aussi joué un grand rôle. L'acquisition du statut impliquait une sorte de déclaration d'intention (montrer sa destinatio animi, dit Ulpien), ${ }^{84}$ car ces incolae étaient recensés, comme les métèques des cités grecques. Les mêmes formalités étaient requises lors de l'abandon du statut, comme le montre l'ex-

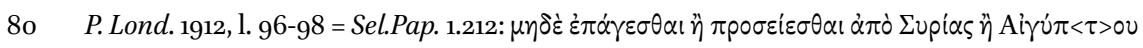

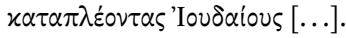

81 Suet. Ner. 37 .

$82 \quad I G$ 14. 1054-1055 = IGR 1149 et 146.

83 BGU 1074. G. Amelotti, 'La posizione degli atleti di fronte al diritto romano', Studia et Documenta Historiae et Iuris 21 (1955), 123-156; réimpr. in idem, ed., Scritti giuridici (Turin 1996), 325-358.

$84 \quad$ D. 50.1.27.2 (Ulp. 2 edict.). 
pression incolatui renuntiare qui apparaît au deuxième siècle de notre ère. ${ }^{85}$ Mais parmi les facteurs d'intégration, l'obligation des doubles munera a dû être décisive. Une inscription de l'époque de Trajan, adressée à un individu qui est remercié pour avoir obtenu que les incolae soient soumis aux doubles munera, prouve que jusqu'à cette époque le statut d'incola était encore fixé au cas par cas; ${ }^{86}$ c'est, semble-t-il, Hadrien qui a posé les règles du ius incolatus, c'est aussi lui qui commence à statuer sur le fait que les étudiants ne sont pas des incolae. ${ }^{87} \mathrm{Du}$ reste le terme incolatus apparaît à cette époque et un texte de Gaius montre que dans la deuxième moitié du deuxième siècle, les incolae non seulement relèvent des deux juridictions (celles de l'origo et du domicile) mais sont soumis aux doubles munera. ${ }^{88}$ Cela veut dire que devenir incola sans le déclarer à sa cité d'origine était considéré comme une fraude: une sorte d'évasion fiscale, selon l'expression de François Jacques. ${ }^{89}$

Decuriones, quos sedibus civitatis, ad quam pertinent, relictis in alia loca transmigrasse probabitur, praeses provinciae in patrium solum revocare et muneribus congruentibus fungi curet.

S'il a été prouvé que les décurions ont abandonné le domicile de la cité à laquelle ils appartiennent afin de s'installer ailleurs, le gouverneur de

85 Voir par exemple $D .50 .1 .34$ (Modestinus 3 regularum). Sur ces expressions, voir Gagliardi 2006, op. cit. (n. 37); Moatti 2014, op. cit. (n. 29).

$86 \quad C I L 5.875$.

87 D. 5 0.1.37 (Callistr. 1 de cogn.): De iure omnium incolarum, quos quaeque civitates sibi vindicant, praesidum provinciarum cognitio est. Cum tamen se quis negat incolam esse, apud eum praesidem provinciae agere debet, sub cuius cura est ea civitas a qua vocatur ad munera, non apud eam, ex qua ipse se dicit oriundum esse: idque divus Hadrianus rescripsit, "Le statut des incolae qu'une cité revendique comme siens relève de la juridiction du gouverneur de province. Quand quelqu'un nie être un incola, il doit engager un procès devant le gouverneur de province sous la tutelle duquel se trouve la cité où il est appelé à exercer les munera, non au gouverneur de province dont relève la cité dont il dit lui-même être originaire". Sur les étudiants: $C$. 10.40.2; 7 .

88 D. 50.1.29. Gaius, libro primo ad edictum provinciale: Incola et his magistratibus parere debet, apud quos incola est, et illis, apud quos civis est: nec tantum municipali iurisdictioni in utroque municipio subiectus est, verum etiam omnibus publicis muneribus fungi debet. "Un incola doit obéir aux magistrats de la cité où il a son domicile et à ceux de la cité dont il est citoyen: et non seulement il est soumis à la juridiction municipale dans les deux municipes, mais il doit y accomplir toutes les charges publiques."

89 F. Jacques, Le privilège de liberté: politique impériale et autonomie municipale dans les cités de l'occident romain (161-244). Coll. de l'Ecole française de Rome 76 (Rome 1984), 349-50. 
la province les ramènera dans leur patrie et les forcera à accomplir leurs devoirs fiscaux. ${ }^{90}$

Une règle largement confirmée par des rescrits impériaux. ${ }^{91}$

On peut bien sûr s'interroger sur l'efficacité de ces normes: les cités appliquaient-elles la règle des deux munera? Les citoyens déclaraient-ils toujours leur changement de domicile? En fait, le nombre de textes jurisprudentiels consacrés à ces affaires révèle à la fois l'importance du problème - le déplacement des citoyens ayant, au niveau local, des conséquences démographiques et financières importantes - et la tentative des empereurs d'y trouver des solutions. De plus, si des citoyens ont échappé au contrôle, comme le suggère le texte d'Ulpien, les gens riches avaient aussi un intérêt à montrer qu'ils étaient honorés en différents endroits. Ainsi la mobilité ne créait-elle pas nécessairement de la fragmentation dans l'empire mais contribuait aussi à tisser des liens entre les cités et à renforcer la perception du territoire impérial comme un monde multi-dimensionnel.

\section{Conclusion: les paradoxes de la migration}

Il n'y eut sans doute jamais aucune doctrine romaine sur la mobilité et le statut des migrants. Le droit romain a le plus souvent réglé les problèmes au cas par cas, ce qui produit l'impression d'une accumulation désordonnée de mesures, même si les empereurs ont parfois émis des normes générales, par exemple sur les incolae, la protection judiciaire des Romains résidant en province, ou encore la mobilité sénatoriale. L'analyse que nous avons proposée nous permet plutôt de dégager quelques paradoxes: le territoire impérial était fluide mais cette fluidité s'accompagnait de nombreuses règles; la liberté de domicile était posée comme un principe mais avec de nombreuses limites et notamment le maintien du lien avec l'origo; l'absent devait être protégé, mais la définition de l'absence se fit de plus en plus restrictive; l'entrée dans les villes ou sur le territoire romain ne faisait pas l'objet de contrôles mais de nombreuses mesures limitaient les flux de population. Ces paradoxes reposent sur une tension, dans les sociétés antiques, entre l'ouverture et la xénophobie, entre la mobilité de fait et l'idéal de sédentarité. Mais cette tension a connu des évolutions, par lesquelles il est possible de mieux appréhender les représentations qu'en

$90 \quad$ D. 50.2.1.pr. (Ulpian, lib. 2 Opin. $)=$ Lenel 2, 2308.

91 Voir par exemple le rescrit de Caracalla à un individu nommé Silvanus (C.10.39.1); voir aussi C.Th.12.1.16 (Constantin); 12.1.76; C. 10.32.31; 32.55 (Théodose et Valentinien). 
avaient les Romains: sous la République, la mobilité était associée à la précarité et l'insécurité sur les routes, sur les mers et dans les lieux d'accueil; c'est donc la protection du migrant que visaient les régulations (hospitium, droit des gens, traités, etc.). A partir de l'Empire, les formes de contrôles, directes et indirectes, se diversifient, sans toutefois que les autorités cherchent à surveiller le territoire en tant que tel. A partir du troisième siècle de notre ère, en revanche, apparaissent la peur de l'étranger et la volonté de limiter les flux. En témoignent les traités avec la Perse, où se lit l'obsession de l'espionnage et du pillage des ressources romaines; la mise en place des comites commerciorum ou des curiosi litorum chargés de contrôler les marchandises et les marchands dans les régions frontalières notamment; ${ }^{92}$ l'apparition d'un délit de mobilité et la répression des 'inutiles'. Le contrôle de la population devient alors une part permanente du 'gouvernement des hommes', dans un empire qui se territorialise.

Paris, Décembre 2015

92 Moatti 2011, op. cit. (n. 45). 



\section{Index Nominum}

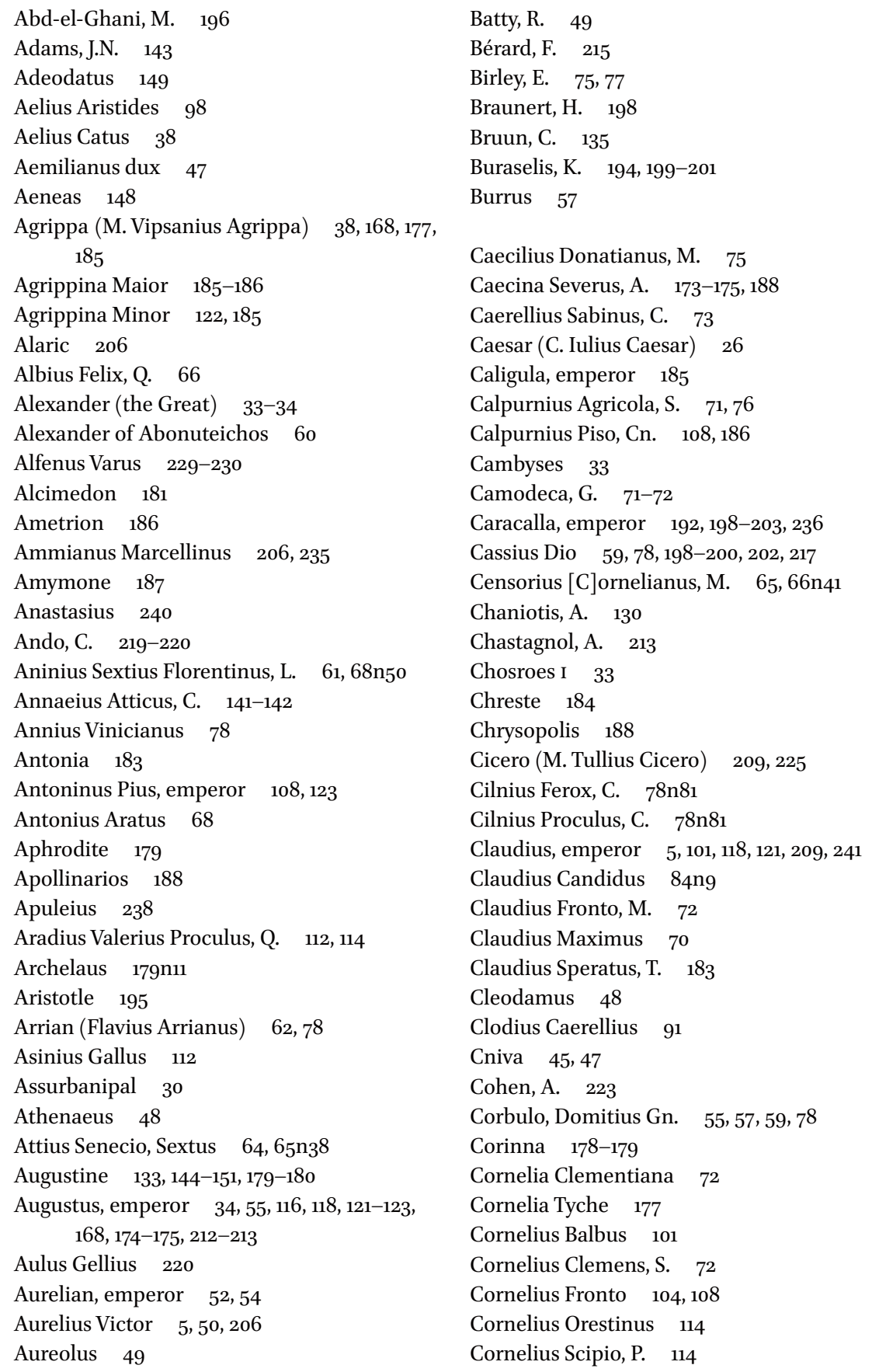


Crassus Frugi, M. 112

Cynthia $177,179,187-188$

Cyrus 33

Dahn, F. 3

Darius I 33

Decius 44-47

Demetrous 188

De Ste Croix, G.E.M. 38

DeVijver, H. 56, 57n11

Dexippus, historiographer $\quad 43,49$

Dexippus, Boetarch 49

Dido 148

Dio Chrysostomos 197

Diocletian, emperor 54

Dionysos 12

Drusus $\quad$ 174-175 $^{-175}$

Eck, W. 119, 124

Elisabeth 11

Erdkamp, P. 16, 50

Eufronia $\quad 176$

Eusebius 206

Eutropius 2, 206

Eutycheis 186

Fabius Cilo $\quad 84$ ng

Faustina 181

Feyerabend, P. $\quad 152$

Fischer, Th. 97

Frank, T. 6

Fraser, P.M. $\quad 40$

Frontinus $\quad 56 \mathrm{n} 7$

Fufidia Clementiana $\quad 72-73$

Fufidius Pollio, L., Iunior $\quad 72-73$

Fufidius Pollio, L., cos. ord. $166 \quad 72$

Fufidia Pollitta 73

Furius Victorinus, T. $\quad 7 \mathrm{on}_{5} 6$

Gaius 216, 225, 243

Gaius Caesar 122

Gallagher, W.R. $\quad 32$

Gallienus, emperor $\quad 47-49$

Gavius Clarus 104

Gavius Maximus, M. 70

Gavius Secundus 87

Germanicus 108, 122, 185

Geta, emperor 199
Glicon 68

Glitius Atilius Agricola 115

Gordian III, emperor $\quad 46,53 n 35$

Gordius Rufinus, Fl. $\quad 75 \mathrm{n} 70$

Goudriaan, K. 192

Groen-Vallinga, M.J. $\quad 36$

Grusková, J. 43

Hadrian, emperor $\quad 55 \mathrm{n} 1,59,66 \mathrm{n} 41,105 \mathrm{n} 20$, $123,187,220,243$

Heckmann, F. 191

Herennia Faventina 9

Herod, king $\quad$ 164, 179nı

Herodes Atticus $\quad 181$

Herodian 199

Herois 188

Hezekiah $\quad 3^{2}$

Hilarion 177

Hin, S. $\quad 16$

Holleran, C. 16

Hopkins, K.M. $\quad 31$

Horden, P. $\quad 13-14,156,162,191$

Hurlet, F. 119

Ignatius, bishop $\quad 96$

Isidora 12

Iulia Maior $\quad 177,185$

Iulia Minor 185

Iulia Restituta 182

Iulia Secunda 177

Iulius Aniensis Seneca Licinianus, C. 77

Iulius Cornutus Tertullus, C. $\quad$ 102n6, 105

Iulius Geminius Marcianus, P. 114

Iulius Maianus, C. 84

Iulius Pisonianus, M. 69

Iulius Restitutus $\quad 182$

Iulius Secundus 177

Iulius Severus, Gaius $\quad 59 n 17$

Iulius Severus, Sextus $\quad 59,60-69,71,109-110$

Iulius Verus, Cn. $\quad 62-63,73 n 67$

Jacques, F. 243

Jerome 206

Jesus of Nazareth 11

John the Baptist 12

Josephus (T. Flavius Josephus) 4, 36, 158, 163-164

Jupiter 121 
Justinianus, emperor $\quad 238$

Juvenal 6

Kuhlmann, P.A. $\quad$ 194, 199

Labeo 230

Laelius 55

Lavan, M. 26

Licinius Silvanus Granianus, Q. $\quad 112$

Ligt, L. de 17

Ligustinius Disertus, C. 67

Livia $\quad{ }^{174-175}$

Livilla $\quad 185$

Livy (T. Livius) 55

Lo Cascio, E. 16

Lollius Urbicus, Q. 62

Longinus 188

Lucian $\quad 60,71,159,168-169$

Lucius $\quad 183-184$

Lucius Caesar 122

Lucius Verus, emperor $\quad 60,71$

Lucretius Severus, L. $\quad 215$

Maiorius Urbanus $\quad 91$

Malchion 143

Malius Natalis, C+[----] 141029

Malthace 179nı

Marcellus 237

Marciana 105 n2o

Marcus Aurelius, emperor $\quad 60,104,181$

Marduk 33

Marianus 49

Marius Maximus 95

Maroboduus 235n54

Martin, G. 43

Mary, mother of Jesus 11

Maximinus Thrax, emperor $\quad 43,89$

Maximus $\quad 176$

Maximus libertus 88

McKeown, N. 153

Messalla 187

Messius Rusticianus, M. $\quad 78 \mathrm{n} 81$

Minicius Faustinus, Gn. 60

Minicius Martialis 95

Minicii Natales 104-105

Moatti, C. 17, 194, 201

Monica 132, 144-151, 179-180

Morris, I. 35
Navigius 179

Nero, emperor $36,57,78,130$

Nerva, emperor $105 \mathrm{n} 20$

Nicolet, C. 209

Noy, D. 15

Numicius Pica Caesianus, P. 113

Nutton, V. 40

Ostrogotha $\quad 45,47$

Ovidius 178

Pacatianus 44

Panciera, S. 100

Paniskos 182

Parker, A.J. $\quad 161$

Patricius 145,148

Paulus 230

Paul, apostle $\quad 95,157,162,164,169-170$

Paul the Deacon 1-4

Pertinax, emperor $\quad 53 \mathrm{n} 35,79$

Petreius, M. 55

Pflaum, H.-G. 74

Philip the Arabian, emperor $\quad 44-46,53 n 35$

Philostratus 49

Plancia Magna 105

Plancina 108

Plancius Varus, M. 102n6, 105

Plautius Silvanus Aelianus, Tib. $\quad 235 \mathrm{n} 54$

Plinius Maior $\quad 33,129$

Plinius Minor $83 n 6,88,104$

Ploutegenia 182

Plutarchus 33,127

Polybius 235

Pomeroy, S.B. 181

Pompeius Falco 58, 114

Pompey (Gn. Pompeius Magnus) 40

Pomponius 216

Pon(...) Magnus 66

Pontienus Magnus 66

Porcius Saturninus Junior, C. 77

Poulter, A. $\quad 43,5^{1}$

Probus, emperor 52, 54

Procopius $\quad 51,158$

Proculus 233

Propertius 177,187

Prowse, T. 134-137, 144

Purcell, N. 13-14, 156, 162, 191

Pyrrhus 117 
Quintius Petrullus, T. 68

Regilla 181

Revocata $\quad 176$

Rhadamistus $\quad 184-185$

Richardson, J. 26

Ritterling, E. 56

Sallust (C. Sallustius Crispus) 55

Salvius Iulianus, P. $\quad 70,72 n 64$

Scheidel, W. 16, 31

Scipio 55

Scott, J.C. 25,30

Sedatius Severianus Iulius Acer Metilius

Nepos Rufinus Ti. Rutilianus

Censor, M. 6o, 62, 110-111

Seleukos of Rhosos $\quad 229$

Seneca (L. Annaeus Seneca) $\quad 8,57,180-181$

Septimius Paterculus, P. $\quad 76$

Septimius Severus, emperor $\quad 91,189$

Septumius Aper, P. 110

Serapis 199

Souris, G. $\quad 117$

Statia Pudentilla $\quad 182$

Sta(tilius?) Telesphorus 68

Statius Priscus Licinius Italicus, M. 6o, 62-66, 69-77

Strabo $\quad 38,217$

Suetonius 124

Sünskes Thompson, J. 197

Sulpicia $\quad 187$

Symmachus 228

Tacitus (P. Cornelius Tacitus) $\quad 55^{-57}, 59,78$, 124, 126, 128, 174-175, 184-186

Tacoma, L.E. $\quad 17,36$

Taonnophoris 179

Tarquinius Priscus 5

Terentia $\quad 187$

Terentius Varro $\quad 217$

Termouthas 188

Tertius Severus, T. $\quad 218$
Thomas, Y. 210

Tiberius, emperor $\quad$ 124, 128

Tiberius Plautius 38

Tiridates $\quad 185$

Titus, emperor $\quad 123,185$

Tobit $3^{2}$

Trajan, emperor $\quad 52,83 n 6,104,105 \mathrm{n} 20,242$

Trebius Germanus, L. $\quad 67 \mathrm{n} 46$

Trebonianus Gallus $\quad 45^{-7}$

Tullius Menophilus 43

Ulpianus 244

Ulpius Avitus, M. 90

Umbricius 6

Urbanilla $\quad 183^{-184}$

Valens, emperor 235

Valeria 188

Valerian, emperor $\quad 47-48$

Valerius Maximianus, M. $\quad 73-74,79$

Valerius Messalinus $\quad 174-175$

Valerius Valerianus, L. $\quad 84 \mathrm{ng}$

Varius Clemens $\quad 83 n 6$

Vencius Iuventianus, S. 215

Venerianus dux 48

Venus 128

Vespasianus, emperor $\quad$ 101-102, 123

Vettius Valens, M. $\quad 78$

Victoria $\quad 177 \mathrm{n} 7$

Voconius Romanus 104

Wolff, H. 39

Woolf, G. $\quad$ 188-189

Yoffee, N. 29

Yoo, J. 18

Zenobia $\quad \mathbf{1 8 4}^{-185}$

Zerbini, A. 18

Zobonis, Gaius 10-11

Zosimus 52, 235 


\section{Index Geographicus}

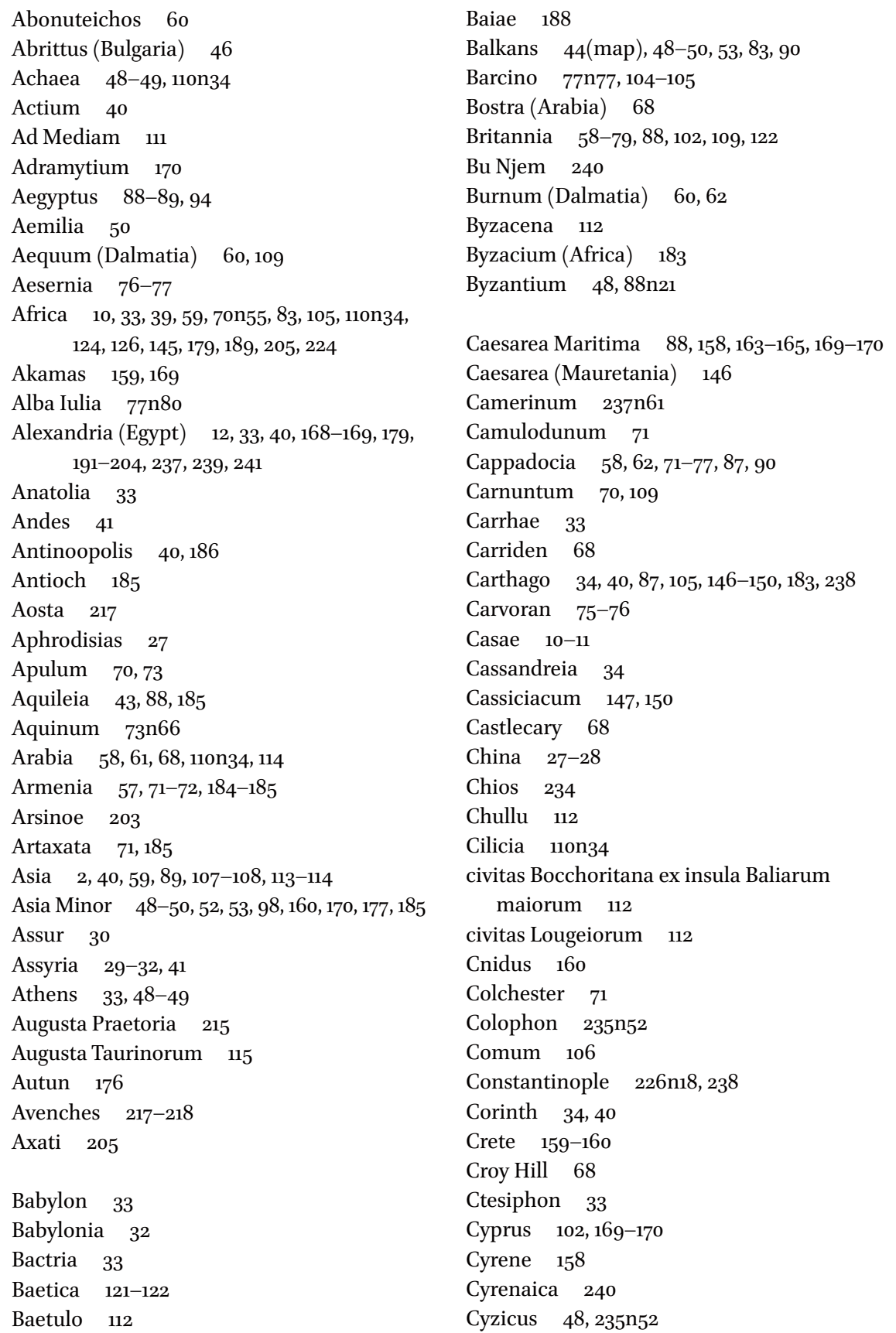


Dacia $39,42-54,70-73,77,182$

Dacia Superior $\quad 58,69,70 n_{55}, 77,109,11$

Dalmatia $39,58,86,176$

Danube region $\quad 42-54,87,90,102$

Dardanelles 48

Demetrias 34

Diana Veteranorum 73

Die 215

Doliche 83

Dor $165^{-169,171(m a p)}$

Ecbatana 32

Egypt $28,32-33,53,67 n 46,88-90,187$, 195-196, 239, 241

Elegeia 59, 62

Elephantine $\quad 33,162$

Ephesos 34, 114, 234n $5^{1}$

Epirus 86

Eryx 128

Eumenaia 69

Europe $\quad 2,29,205$

Faustinianensis 112

Fayum 40

Ferentillum (Etruria) 184

France $\quad 207$

Friuli 1

Gadès 224

Galatia $\quad 72$

Galilee $\quad 32$

Gallia Aquitania $\quad 86,141-142$

Gallia Belgica $\quad 53,84,86,88$

Gallia Comata 122

Gallia Lugdunensis 86

Gallia Narbonensis $\quad 61,101,103,105$

Gaul 2, 26, 34, 39, 40, 48, 88, 90, 121-122, 128-130, 142

Germania $\quad 1-3,39,55,58,83,88-89,185$

Germania Inferior $88,89 n 27,102,110 n 34$

Germania Superior $67 \mathrm{n} 46,82,84,110 n 34$

Giza $\quad 28$

Golgotha $\quad 167$

Gracchuris 36

Greece $\quad 48-50,181,232$

Hadrumetum 112

Heddernheim 82
Hippo $\quad 145^{-147}$

Hispania 124, 126, 128

Hispania citerior 121-122, 124

Hispania Tarraconensis $\quad 5^{8}$

Hof Hakarmel $\quad 167$

Iberia $\quad 185$

Iberian peninsula $\quad 101$

Ilium 177

Illyria $\quad 2,177$

Illyricum 44, $5^{2}$

Intercisa 38

Isola Sacra $\quad 132-144,150-154$

Israel $\quad 32,163$

Isthmus of Corinth 36

Istria $\quad 106$

Istrum 43

Italy $2-3,5,34-36,39,43,47,50,98$, 106-107, 114, 121, 141, 159, 168, 180, 183, 189, 209, 225n8, 227, 229

Jerusalem $\quad 32,65$

Judaea 11, 58-69, 63n34, 102, 109, 110n34, 170

Judaea-Palaestina 99

Kafr Lam $\quad 167$

Karanis 203

Karystos 92n37

Khorsabad 30

Klaudiopolis $\quad 188$

Koptos 182

Kos 170

Krim 87

Laodiceia 88

Lasea 160

Le Kef 214n19

Leptis $\quad 189$

Lesbos $\quad 185$

Levant, Southern $\quad 155^{-172}$

Libya 184

Lisbon 129

Lishan 27

London 31

Luceria (Apulia) 72, 77

Lugdunum 87, 200

Lugdunum Convenarum 36 
$\begin{array}{ll}\text { Lycia } & 89,186,233^{-234} \\ \text { Lyon } & 87,215\end{array}$

Macedonia $\quad 45,48-49,86,90,108-109$

Mactar 187

Madaba $\quad 167$

Madauros 146-147

Mainz 91

Malea 159

Marcianopolis 45

Margiana 33

Maritsa valley 45

Maryport 65

Massilia 118, 128

Mauretania 7on55, 183

Mauretania Tingitana 89,130

Media 32

Megalopolis 35

Memphis 187

Mesopotamia 32,91

Messene 35

Mididi 112

Mikhmoret 168

Milan 147-150, 179

Miletus 170

Misenum 74

Mitylene 34

Moesia 38, 58, 235n54

Moesia Inferior $\quad 42-54,58,69,88 \mathrm{n} 21,109$

Moesia Superior $\quad 43,70$

Monte Cassino 1-4

Munigua 123

Myra (Lycia) $\quad 160,170$

Narbonne 211-212, 216n23, 217

Neapolis (Judaea) 114

Newe Yam 168

Nicopolis ad Istrum (Bulgaria) 43, 45, 51, 53

Nikopolis 40

Nile Delta 162

Nimrud 30

Nineveh 30,32

Noricum 58

Novae 45

Numidia 73

Obernburg 9in35

Olispo (Lusitania) 129
Ostia $133-144,147,150-154,162,179$

Oxyrhynchus 186, 203, 242

Pamphilia 186

Pannonia $55,74,76$

Pannonia Inferior $\quad 58,65$

Pannonia Superior $58,64,70$

Patara 170

Patavium 107

Pentapolis 240

Pergamon 234n51

Perge (Pamphylia) 102n6, 105

Perinthos 88

Persepolis 33

Persia 232, 234n 57

Pharos 159

Philoppopolis $45,47,5^{0}, 53$

Phoenix 147

Picenum 50

Piraeus 159

Pisa 122

Pitinum Mergens $\quad 67 n 46$

Poitiers 60

Pola 107

Pontus 40, 87

Pontus-Bithynia $\quad 58,88 \mathrm{n} 21,113$

Portus 158

Praeneste 103

Ptolemais $\quad 156$

Prusa $83 n 6$

Raetia $\quad 5^{8}$

Ravenna 9, 11, 74

Rhine 1-2

Rhodes $170,235 \mathrm{n}^{2}$

Rome $5^{-7}, 16,27,31,33,36,38,47,94,96,98$, 101-103, 106, 109, 110-115, 116-131, 133 , 147-150, 152, 169-170, 177, 181, 185-187, 189, 207, 220, 224, 225n8, 228, 235n 57 , 236-238

Rome, Campus Martius 108

Sabora 123

Saguntum 129

Saldae 83

Salmone 160

Salona 88

Samothrake 108 n28 
Sarmizegetusa $\quad 77,111$

Scandinavia 3

Scotland 68

Sdot Yam 167-168

Sebastos at Caesarea $\quad 164-165,168$

Seleucia (Pieria) 88

Setif (Algeria) $\quad 177 \mathrm{n}_{7}$

Sicca Veneria $214 \mathrm{n} 19$

Sichuan 28

Sicily $34,103,105,126$

Sidon 159,170

Sirmium 43

Spain $34,123,177$

Spalato 182

Strato's Tower 163

Sub Cununi 7 on55

Susiana 33

Syria $63,67,71,73 n 67,88-89,96,108,110$, 168,170

Syria Palaestina $\quad 58,63 n 34$

Syria Phoenice $5^{8}$

Tarraco $\quad 123,130$

Tebtynis 204

Teanum Sidicinum $\quad$ 71, 73, 77

Tel Dor 171(map)
Teotihuacan 28

Tergeste 103

Teutoburgium 65

Thaenae 112

Thagaste $\quad 146-150$

Theadelphia 204

Thebes 34

Thessalonica $\quad 48,88$

Thermopylae 48

Thrace $33,38,42-54$

Thuburbo Minus $\quad 77 \mathrm{n} 79$

Tibur 38

Tifernum Tiberinum $\quad 106$

Timgad 39

Tivoli 103

Trier 75

Tripolitania 240

Tyre 69,170

Vasio Vocontiorum 110n34

Viminacium 43, 47

Volubilis $\quad 125,130$

York 62

Zama Regia $\quad 112$ 


\section{Index Rerum}

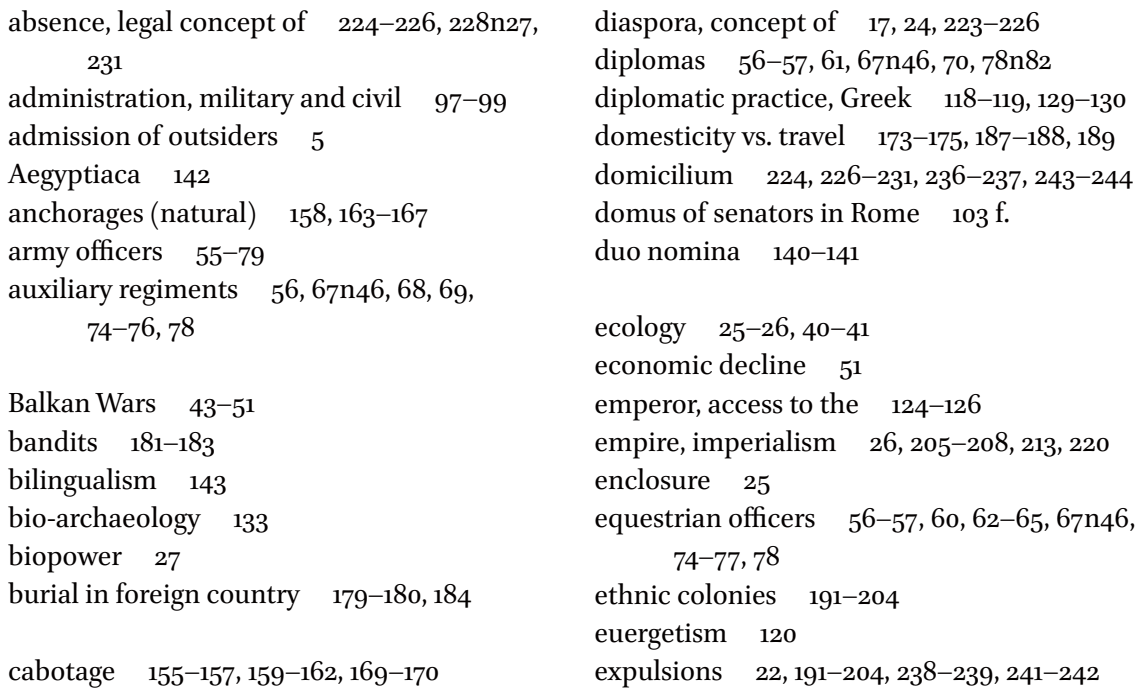

diplomas $\quad 56-57,61,67 \mathrm{n} 46,70,78 \mathrm{n} 82$

diplomatic practice, Greek $\quad$ 118-119, 129-130 domesticity vs. travel $\quad 173-175,187-188,189$

domicilium 224, 226-231, 236-237, 243-244 domus of senators in Rome $103 \mathrm{f}$.

duo nomina $\quad 140-141$

ecology $\quad 25^{-26}, 40-41$

economic decline $5^{1}$

emperor, access to the $\quad 124-126$

empire, imperialism $\quad 26,205^{-208,213,} 220$

enclosure 25

equestrian officers $\quad 56-57,60,62-65,67 \mathrm{n} 46$, 74- 77,78

ethnic colonies 191-204

euergetism 120

expulsions $\quad 22,191-204,238-239,241-242$

female-authored travelogue $\quad$ 186-187

fides 128

forced labour $\quad 27-31$

freedmen 224, 237

geographical determinism $\quad 2-3$

gifts 121

globalization 15

glocalization 15

governors on the move $107 \mathrm{ff}$.

governors, comites $107 \mathrm{ff}$.

grain $\quad 159-160,168-169$

guilds, see collegia

harbours (artificial) 158, 160, 164, 168

homines novi $103 \mathrm{f}$.

identity $\quad 205^{-208,219-221}$

illness $\quad 179-180$

imperial cult 122

imperialism, see empire

incolae 22, 207, 210, 213, 214, 216, 218, 219, 224, 230-231, 242-244

inconsistencies $132,15^{2-154}$

inhumation $\quad$ 138-139

injuries 179

integration $\quad 219-221$ 
integration, of migrants $\quad 241-244$

inutility, ancient concept of $\quad 238-239,245$

invasions 19, 42-54

isotopes $17,21,133^{-137}$

kinship diplomacy $\quad 128$

labour migration $\quad 22$

Latin law 207, 218, 219

law (maritime) 159, 163-4, 166-167

legal categorisations of migrants $\quad 205^{-221}$

legati $120,124,126$

legationes $\quad 116-131$

legions $\quad 55,56,58-62,65^{-69}, 70,71,73,77,78$

lex Gabinia $\quad 117$

linen $197 \mathrm{n} 32,198$

linen-weavers 191-204

linouphoi see linen-weavers

lodging, cost of 53

loyalty $\quad 121-122,128,129$

marriage contracts $\quad 12$

migration controls $\quad 235^{-244}$

migration narratives $\quad 144-15^{1}$

migration policy $\quad 222-223,229,232-240$

migration, by children $\quad 134-137,153^{-154}$

migration, by families $\quad 135,148-151$

migration, chain $\quad$ 195, 204

migration, internal 196

migration, kinship $\quad$ 195, 204

migration, moral judgement of $3,5^{-6}$, $145^{-146}$

migration, permanent $\quad$ 147-148

migration, return 148

migration, rural 196

migration, rural-urban $\quad$ 197, 197n28, 204

migration, step-wise $\quad 147$

mobility, controls of 23

mobility, cost of 24

mobility, cross-empire $\quad 23,55^{-79}$

mobility, definition of $\quad 176,189$

mobility, diplomatic $\quad 21,116-131$

mobility, female $\quad 9-13,22-23,148-150$, 173-190

mobility, forced $\quad 3,27-31$

mobility, military $\quad 20,23,36-37,55^{-79}$, 80-99

mobility, senatorial $\quad 20-21,100-115$ mobility, of students $\quad 226,231,238,242-243$

mobility, voluntary 3

munera 224, 231, 237, 243-244

munificentia 125

murder $\quad 181$

mutatio soli $224,228,236$

networks (Mediterranean) $\quad 156,170$

officium $\quad 82-84,86-87$

origins, of migrants $\quad 135^{-136}$

origo $226,228-231,237,243-244$

origo gentis $\quad 1-4$

out-posts $\quad 81-82,98$

passengers (on ships) 156, 159, 164, 167

patronage $\quad 63-69,73-78,111 f f$.

peregrini 224, 227-228, 234, 236

pilgrims $\quad 166-167$

plague $5^{0}$

polis $\quad 34-35$

political communication $\quad 116-117,124$

population pressure $\quad 2-3$

portus expeditionales 88

promotion patterns $\quad 58-60,65,70-71,73,79$

prosperitas 124

provincial assemblies 120

provincial cities, consequences of citizens

becoming senators $103 \mathrm{ff}$.

provincial governor $119,125,130$

push and pull factors 8

recruits $\quad 88-89$

relocation $\quad 38-39$

resettlement $\quad 38-39,54$

residents 207, 210, 213-216, 218, 219

riots 191, 194-195, 197-199, 199n41, 200-203

routes (maritime) $155,158,160-162,167-168$

sailing season $\quad 157-158,160-161$

sample size 135

sea voyage $\quad 15^{8-159,160-161, ~ 164, ~ 167, ~ 169-170 ~}$

Second Punic War 50

senators, as patrons $111 \mathrm{ff}$.

senators, economy $103 \mathrm{ff}$.

senators, investment in their city of origin 104-105

senators, origo $100 \mathrm{ff}$. 
senators, Rome as center of their life

$$
\text { 107-110 }
$$

senators, transfer of provincial income to

Rome $\quad 105^{-106}$

senators, visitors from the provinces $110 \mathrm{ff}$.

shipwrecks $13,22,157-158,160-161,163-167$, $172,176-179,180-181$

slavery $5^{0}$

slaves $135,140,142,153-154,223-224,241 n 77$

social caging $\quad 24,188$

soldiers, special assignments of $\quad 82-83$

state formation 19

stationes $\quad 241-242$

statutes $207,208,210,219-221$

synoecism $\quad 34-35$

tabulae patronatus $111 \mathrm{ff}$.

territoriality $\quad 26-27$

textile branches $\quad 198,202-203$

textile production 197-198, 201

traders 223, 239, 241-242, 245

transfer, of animals 91

transfer, of material 90 transfer, of prisoners $\quad 95^{-96}$

transfer, of soldiers $\quad 89$

transfer, of supplies $9^{0}$

transportation costs $\quad 5^{0,53}$

travel companions $\quad 174-176,188-189$

travellers $\quad 155^{-157}, 159,164-165$

treaties with foreign peoples $\quad 232-235$

tria nomina $\quad 140-141$

univira $149-150$

urbanization $\quad 28-29$

utilitas 124

vexillatio(nes) $\quad 87$

Völkerwanderung 3

warfare, impact of $\quad 42-54$

wars $\quad 55^{-79}$

wealth, variations in 141

weather $157-158,160-161,164,168-169$

winds $\quad 158-160,162-163$

xenoi 191-192, 199, 199n41, 202 


\section{Index Locorum}

1. Literary Evidence

II Kings 18.31-32

Ach. Tat. $5 \cdot 7$

Act. Ap.
$\begin{aligned} & 23.23 \\ & 27.1-28.5 \\ & 27.2 \\ & 27.9-11 \\ & 27.9-12\end{aligned}$

Ael. Arist. Orat. 26.67

Ambros. Off. 3.7.44-52

Amm. 23.5.17

31.4-5

Apul. Met. 1.7, 15, 23; 3.28; 4.6-22; 7.4, 12, 13; 8.15, 17-18

1.17

8.23

Arr. Ectaxis 5

24

Arist. Ath. pol. 1329b

Aug. Conf.

2.3 .5

3.1.1

4.2 .2

4.4 .7

4.7 .12

5.8 .14

5.8 .15

5.12 .22

5.13 .23

6.1

6.1.1

6.15 .25
32

182n23

11

95

16o-161

170

16o-161n16

164

98

228

$46 \mathrm{n} 12$

235

182 n23

227n21

238

$78 \mathrm{n} 84$

$78 n 84$

195

$147 \mathrm{n}^{\mathrm{o}}-5^{2,}, 148$

$147 \mathrm{n}_{52}$

149

147n53

$147 \mathrm{n}_{54}$

147n55

148n62

147n55, n57

147n57

180

147n56, 148n62

149
$9 \cdot 3 \cdot 5^{-9.6 .14}$

9.6.14

9.8.17

9.10-11

9.10.23

9.11.28

9.12.29

Aug. Ep. 10.1-2

46.1

$147 \mathrm{n}^{8} 8$

149

147n59

179

147n59

147 n6o

149

145 n 44

240

Aul.Gel. NA 16.13.4 16.13.8-9

$124 \mathrm{n}^{2}$

220

Aur. Vict. Caes. 11

29.2-5

$46 \mathrm{n} 11$

$33 \cdot 3$

$49 n 22$

$34 \cdot 3$

50

Caes. Bello Gallico

$3^{6}$

Cedrenus 1.454

$47 \mathrm{n} 15$

Cic. Balb. $3^{2}$

Caec. 20.57

237

Flac. 29.71

225

$234 n_{51}$

8

209

I Verr. 54

$117 n_{5}$

196 n2o

$117 \mathrm{n}_{5}$

217

$235^{n}{ }^{2}$

$235^{n} 5^{2}$

103 n11

78

61, 71

62

$60 n 19$

$71 n 59$

$85 \mathrm{n} 12$

$192 n 6$

199n42 


\begin{tabular}{|c|c|c|c|}
\hline $77(78) \cdot 22 \cdot 1-23 \cdot 3$ & $199 n 41-42$ & $4.10-13$ & $202 n_{54}$ \\
\hline $77(78) .23 .2$ & 199 & $6.8 .2 \mathrm{f}$ & 89 \\
\hline $77(78) \cdot 23 \cdot 3$ & 200 & & \\
\hline $79(78) \cdot 1-5$ & $202 n_{54}$ & Hier. Ep. 108 & 166n36 \\
\hline $\begin{array}{l}\text { Dexipp. Scythica } \\
\quad \text { Codex Vindobonensis }\end{array}$ & $43,46 \mathrm{n} 10$ & Isid. Orig. 9.4.37 & $227 \mathrm{n} 23$ \\
\hline gr. 73 fols. $192-193$ & $49 n 22$ & J. $A J 15.333$ & 163 \\
\hline fols. 194 and 195 & $46 n 11$ & 17.10 .1 & 179n11 \\
\hline frg. 23 & 46 nio & $B J \cdot 3 \cdot 540$ & $36 \mathrm{n} 34$ \\
\hline frg. 24 & $46 n 11$ & Vit. $14-16$ & $15^{8}$ \\
\hline \multirow[t]{2}{*}{ frg. 25.4} & $49 n 22$ & & \\
\hline & & Joh.Chrys. De virg. 24.2 & $182 \mathrm{n} 23$ \\
\hline D. Chr. 11.32 \& $11.37-39$ & $196 \mathrm{n} 21$ & & \\
\hline 32.36 & 197 & Jordan. Get. 101-3 & $46 \mathrm{n} 11$ \\
\hline Eus. Onom. s.v. 'Dor' & 166 & Juv. $15 \cdot 33-38 \& 15 \cdot 75^{-83}$ & $196 \mathrm{n} 20$ \\
\hline Eutropius 9.15.1 & $5^{2}$ & Liv. 30.15 .13 & $55^{\mathrm{n} 2}$ \\
\hline \multirow[t]{2}{*}{ Flor. 2.13 .60} & $196 \mathrm{n} 20$ & Luc. Alex. 27 & 60 \\
\hline & & Nav. 7-9 & 159 \\
\hline \multirow[t]{2}{*}{$\begin{array}{l}\text { Fronto ad Anton. } 2.8 \\
\qquad \text { (Van den Hout, p. 166f) }\end{array}$} & 108 & Hist. Conscr. 20 & 71 \\
\hline & & Lucan. 8.543 \& 10.54 & $196 \mathrm{n} 20$ \\
\hline нА Ant. Pius $8.7-9$ & $7 \mathrm{on}_{5} 6$ & & \\
\hline Aurelian 39.7 & $5^{2}$ & Luke $1.39-40$ & 11 \\
\hline Carac. 3.1 & $192 n 6$ & & \\
\hline $6.2-3$ & $199 n 40-42$ & Mart. 3.5 & $227 \mathrm{n} 21$ \\
\hline $6.6-7.2$ & $202 n_{54}$ & & \\
\hline Hadr. 12.3-4 & $123-124$ & Men. Rh. 423 & $127 \mathrm{n} 41$ \\
\hline Gall. 6.8 & $48 \mathrm{n} 17$ & & \\
\hline 7.2 & $48 \mathrm{n} 17$ & Nicolaus of Damascus, & \\
\hline $13.6-10$ & $48 \mathrm{n} 20,49 n 22$ & $F G H, 2$ A: 421-2 & 177ng \\
\hline 13.7 & $48 \mathrm{n} 21$ & & \\
\hline 13.8 & 48n19, 49n22 & Oracula Sybillina $13.13^{-20}$ & $46 n 12$ \\
\hline M. Ant. Phil. 8.6 & $59 \mathrm{n} 18$ & & \\
\hline 8.7 & 71 & Oros. 7.23 .1 & 5 on26 \\
\hline 9.1 & $7 \mathrm{ln} 58$ & & \\
\hline Marc. Aur. 11.8 & $\begin{array}{l}104 \mathrm{n}_{17} \\
236 \mathrm{n}_{5} 8\end{array}$ & $\begin{array}{l}\text { Ov. Am. } 2.11 \cdot 9^{-12,17-26} \\
\quad \text { Ars } 1.255\end{array}$ & $\begin{array}{l}178 \\
188 \mathrm{n} 47\end{array}$ \\
\hline Probus 18.1 & $5^{2}$ & & \\
\hline Sept. Sev. 1.15 & 189-190 & Paneg. Lat. 8.21.1 & $53 n 34$ \\
\hline \multirow[t]{2}{*}{ Verus 7.1} & $7 \ln 58$ & & \\
\hline & & Paul the Deacon, Historia & \\
\hline Hdn. $4 \cdot 7 \cdot 2$ & $199 n 42$ & Longobardorum 1.1 & $1-2$ \\
\hline 4.8.6-9.8 & $199 n 42$ & & \\
\hline $4.8-9$ & $199 n 40-41$ & Petr. Patr. $F H G$ 4.186f, frg 8 & $43 n_{5}$ \\
\hline
\end{tabular}




\begin{tabular}{|c|c|c|c|}
\hline Petr. Sat. 95 bis & $227 \mathrm{n} 21$ & $\begin{array}{l}7 \cdot 3 \cdot 10 \\
17 \cdot 1.13\end{array}$ & $\begin{array}{l}38 \\
197 n 30\end{array}$ \\
\hline Ph. Leg. ad Gaium 3.15 & $161 n 16$ & & \\
\hline Post. Cain. 7.22 & 161n16 & Suet. Aug. 101.4 & 93n39 \\
\hline & & Ner. 37 & 242 \\
\hline Philostr. VA 3.32 & $196 \mathrm{n} 21$ & Tib. 7 & $185 n 34$ \\
\hline & & 31 & $122 \mathrm{n} 25$ \\
\hline Plin. NH. 6.18 (47) & 33 & 31.2 & $124-125$ \\
\hline $9.5(4) \cdot 9$ & 129 & $37 \cdot 7$ & $235^{n} 5^{2}$ \\
\hline 33.16 .54 & $122 \mathrm{n} 20$ & & \\
\hline & & Sulpicia $3.14 \& 3.15$ & 187 \\
\hline Plin. Ep. 6.4 & $187 n 47$ & & \\
\hline $6.19 \cdot 4$ & 104 & Syncellus 459 = Dexipp. & \\
\hline $10.17 \mathrm{~b}$ & $83 n 6$ & $\operatorname{frg} 17$ & $46 \mathrm{n} 11$ \\
\hline 10.18 & $83 n 6$ & 467 & $49 n 23$ \\
\hline 10.21 & $87-88$ & 470 & $5^{2 n} 33$ \\
\hline $10.27 \mathrm{f}$ & $88 \mathrm{n} 22$ & & \\
\hline $10.43^{f}$ & $88 \mathrm{n} 21$ & Tac. Ann. $1.11 .3 \mathrm{f}$ & 93n39 \\
\hline Paneg. 31.2 & $196 \mathrm{n} 20$ & 1.40 .1 & $185 n 36$ \\
\hline & & 1.41 & 187 \\
\hline Plut. Crass. 31 & $33 \mathrm{n} 27$ & 1.88 .1 & $122 n 25$ \\
\hline Praec. ger. Rei publ. 805A & 127 & 2.54 .1 & $185 n 35$ \\
\hline & & 2.63 & $235^{\mathrm{n}} 54$ \\
\hline Procop. Aed. 3.3.9-11 & $236 n 57$ & 2.75 .1 & 186 \\
\hline Bella 6.20 .18 & $5 \ln 29$ & 2.79 .1 & 186n39 \\
\hline & & 2.80 .1 & $108 \mathrm{n} 28$ \\
\hline Procop.Gaz. Pan.19 & $15^{8}$ & 3.9 .2 & 108n30 \\
\hline & & $3 \cdot 33^{-}-34$ & $174-175$ \\
\hline Prop. 1.8.1-2, $5^{-8}$ & $177^{-178}$ & $3 \cdot 6 o-63$ & $124-125$ \\
\hline 1.11 & $187-188$ & 4.36 .2 & $235^{n} 5^{2}$ \\
\hline 2.19 & 188 & $4 \cdot 37-38$ & $122 \mathrm{n} 25$ \\
\hline $2.26 .1-4$ & 179 & 4.43 & 128 \\
\hline & & 11.20 .2 & 56 \\
\hline Quint. Inst. 6.3.79 & $121 n 19$ & $11.23-25$ & 5 \\
\hline $6.33 \cdot 77$ & $122 \mathrm{n} 25,130$ & 12.23 .1 & 103n11 \\
\hline 8.5 .15 & $122 \mathrm{n} 22$ & 12.43 .4 & $196 \mathrm{n} 20$ \\
\hline & & $12.5^{1}$ & 185 \\
\hline Sall. Cat. 45.1 & 55 & 13.8 .1 & $57-5^{8}$ \\
\hline 59.6 & 55 & $14 \cdot 42-45$ & 106 \\
\hline & & 15.18 & $158 \mathrm{ng}$ \\
\hline Sen. Cons. ad Helv. 6.2 & $6-7$ & 15.28 .3 & $78 \mathrm{n} 83$ \\
\hline 7.1 & $3-4,7-8$ & $18.1-20.1$ & $5^{6 \mathrm{n} 6}$ \\
\hline $19 \cdot 4$ & $180-181$ & Agr. 5.4 & $5^{6}$ \\
\hline $19 \cdot 5,7$ & $181 n 15$ & 17.2 & $5^{6 \mathrm{n}} 7$ \\
\hline Ep. 51.3 & $187 \mathrm{n} 47$ & 39.2 & $56 n 7$ \\
\hline & & 41.2 & 33 \\
\hline Sil. $265^{-294}$ & $129 n 49$ & Germ. 28-29 & $38 n 43$ \\
\hline & & Hist. 1.11 & $196 \mathrm{n} 20$ \\
\hline
\end{tabular}




\begin{tabular}{|c|c|c|c|}
\hline Zon. 12.20 & $46 \mathrm{n} 11$ & $\begin{array}{l}1963=\text { Lex Salp. } 29= \\
\text { FIRA I } 202\end{array}$ & $225^{\text {n } 8}$ \\
\hline Zos. 1.23 & $46 \mathrm{n} 11$ & $1964=I L S 6089$ & 216 \\
\hline $1.36 .1-2$ & $48 \mathrm{n} 16$ & 4055 & 124 \\
\hline 1.39 .1 & $49 n 23$ & 4057 & 126 \\
\hline 1.71 .1 & $5^{2}$ & 4192 & 124 \\
\hline $3 \cdot 3^{-4}$ & $235^{n} 53$ & $4201=R I T 331=I L S 6927$ & $123 n 31$ \\
\hline & & 4208 & 124 \\
\hline & & $4509=C I L 2.6145=$ & \\
\hline 2. Epigraphic Evidence & & $I L S 1029=I R C 4.30$ & $104-105$ \\
\hline & & 6150 & $77 \mathrm{n} 77$ \\
\hline$A E$ 1927, 95 & 69 & & \\
\hline 1933, 249 & $111 n 39$ & $C I L 2 / 5,871=I L S 6092$ & 123 \\
\hline 1936,66 & 112 & $1022=2.5439$ and & \\
\hline 1946,1 & $78 \mathrm{n} 81$ & $6439 \mathrm{a}=I L S 6087$ & $214 \mathrm{n} 18$ \\
\hline 1956,124 & 74 & & \\
\hline $1965,205=A E 1967,444$ & 108 & $C I L 3 \cdot 412=I G R 4.1404=$ & \\
\hline 1971,267 & 77 & Eck et al., 'Sacrae litterae', & \\
\hline 1972, $577=$ I. Eph. 3.713 & 114 & $376 \mathrm{n} 53=$ SEG $27,763=$ & \\
\hline 1977,171 & $92 n 38$ & Petzl, Inschriften von & \\
\hline 1977,807 & $107 \mathrm{n} 25$ & Smyrna, 604 & $107 \mathrm{n} 25$ \\
\hline 1981,640 & $6 o n 19$ & $1061=I L S 4006=$ & \\
\hline $1984,553=A E 1997,862$ & $112 \mathrm{n} 41$ & IDR 3.5 .185 & 7 on 55 \\
\hline 1985,829 & $84 n 9$ & $1416=I D R 3 \cdot 3.276$ & $705_{55}$ \\
\hline 1990, 854 = Inscriptions & & $1075=\operatorname{ILS} 3087=$ & \\
\hline de la Mésie Supérieur & & IDR $3 \cdot 5.107$ & $73 n 66$ \\
\hline Nr. 3 & $89 n 28$ & $1562=I L S 3896$ & 111 \\
\hline $1990,85^{8}$ & $84 \mathrm{n} 12$ & 1559,1579 & $182 n 23$ \\
\hline 1998, $804=$ Eck und & & 1585 & 182 \\
\hline Navarro, 'Das Ehrenmon & nent & 2399 & 182 \\
\hline der Colonia Carthago für & & 2544 & $182 n 23$ \\
\hline L. Minicius Natalis & & $2830=9891=I L S 1056$ & $60-61$ \\
\hline Quadronius Verus in & & $3107=I L C V 4360$ & $176-177$ \\
\hline seiner Heimatstadt & & $5^{212}$ & $226 n 16$ \\
\hline Barcino' & 105 & 8830 & $182 n 23$ \\
\hline $\begin{array}{l}2005,1487=S E G 55.145^{2} \\
2006,1836\end{array}$ & $\begin{array}{l}233^{-234} \\
61\end{array}$ & 14203, 9 & $107 \mathrm{n} 25$ \\
\hline 2007,1763 & $705_{55}$ & $C I L 5 \cdot 53^{2}=I L S 6680$ & 113 \\
\hline 2008,531 & $10 n 24$ & 875 & 243 \\
\hline 2010,1856 & 61 & & \\
\hline 2011,271 & 72 & $C I L 6.130=I L S 2091$ & $83 n 7$ \\
\hline & & 234 & $182 \mathrm{n} 23$ \\
\hline$B R G K 40$ (196o) 179, nr. 151 & 91 & $1377=31640=I L S 1098$ & $72-73$ \\
\hline & & $1408=I L S 1141$ & $84 n 9$ \\
\hline$C I L 1.2965 \mathrm{a}$ & $9 \mathrm{n} 21$ & $15^{23}=I L S 1092$ & $63-64$ \\
\hline & & 1684 & $112 \mathrm{n} 44$ \\
\hline$C I L 2.1055=I L S 6916=$ & & $1686=I L S 6111 \mathrm{c}$ & $112 \mathrm{n} 42$ \\
\hline CILA 2.1.207 & 215 & 2357 & $227 \mathrm{n} 22$ \\
\hline 1389, 2968, 3479 & $182 n 23$ & 3505 & $65 n_{3} 8$ \\
\hline
\end{tabular}




\begin{tabular}{|c|c|c|c|}
\hline CIL 6 (cont.) & & $5072=$ ISchweiz $208=$ & \\
\hline $3835=31742=31743=$ & & RIS 74 & $218 \mathrm{n} 29$ \\
\hline ILS 911 & $113 n 49$ & $5073=$ ISchweiz $207=$ & \\
\hline 11602 & 187 & RIS 75 & $218 \mathrm{n} 29$ \\
\hline $12056=C L E 1026$ & 183 & $5091=I S c h w e i z 211=$ & \\
\hline $20307 \mathrm{a}$ & $182 n 23$ & RIS 83 & $219 n 31$ \\
\hline 22867 & $143 n 37$ & 6429 & $182 \mathrm{n} 23$ \\
\hline 31267 & $121 n 18$ & 7733 & 84 \\
\hline $4105^{0}$ & 114 & & \\
\hline 41054 & 113 & $C I L$ 14. $125=I L S 2223$ & $92 n 38$ \\
\hline & & $3608=I L S 986$ & $235 \mathrm{n} 54$ \\
\hline$C I L 8.152=C L E 516$ & 183 & & \\
\hline 647 & 187 & CIL 16 App., no. 13 & 66 \\
\hline 1175 & 77 & 46 & $78 \mathrm{n} 81$ \\
\hline $1641=I L S 6818$ & $214 \mathrm{n} 19$ & 69 & $78 \mathrm{n} 82$ \\
\hline $2728=I L S 5795$ & $83 n 6$ & 108 & $705_{55}$ \\
\hline $20414=I L C V 1476 \mathrm{a}$ & $177 \mathrm{n}_{7}$ & & \\
\hline 22737 & 126 & $C L E 436=C I L 6.20674$ & 177 \\
\hline 26582 & 126 & $1845=C I L 11.4991$ & 184 \\
\hline$C I L 9 \cdot 2649=I L S 273^{2}$ & $76-77$ & $E C O 90=I L C V 1540=I C G 5$ & 176 \\
\hline CIL 10. 3646 & $10 n 22$ & Fasti Ostienses & 111035 \\
\hline 7507 & 126 & & \\
\hline & & HAE $12-16,1923=A E 1962$, & \\
\hline CIL 11.59 & $9 \mathrm{n} 22$ & 288 & 123 \\
\hline 61 & 9 n2o & & \\
\hline 65 & $10 n 22$ & IAM 2.2.349, 350, 353, 356, 357, & \\
\hline 383 & $78 \mathrm{n} 84$ & $358,359,360,384,402$ & $125^{-126}$ \\
\hline $1420.33-37$ & 122 & $2.2 .35^{0}$ & $1305_{5} 6$ \\
\hline 1421.42 & $122 \mathrm{n} 21$ & 2.2 .448 & 124 \\
\hline 3108 & 66 & & \\
\hline 5960 & 67 & I.Eph. 2.207 & $107 \mathrm{n} 25$ \\
\hline 6123 & $67 \mathrm{n} 46$ & 2.208 & $107 \mathrm{n} 25$ \\
\hline & & $215=S E G 4.15^{2}=P H I$ & \\
\hline$C I L 12.15^{8} 5=I L S 6992=$ & & 247938 & $201 n 49$ \\
\hline$C A G 26=I L N 7,20$ & 215 & & \\
\hline $4333=I L S 112$ & $211-213$ & $I G 2^{2} \cdot 3669$ & $49 n 22$ \\
\hline & & $7 \cdot 3426$ & $49 n 22$ \\
\hline CIL 13.259 & $182 \mathrm{n} 23$ & $12.5,132$ & $107 \mathrm{n} 25$ \\
\hline $1668=I L S 212$ & 5ng, 209 & $14.1054-1055=I G R 1$ & \\
\hline 2282 & $182 \mathrm{n} 23$ & $149 \& 146$ & $242 n 82$ \\
\hline 2667 & $182 \mathrm{n} 23$ & & \\
\hline $2828=I L S 7047$ & 90 & IGLS 13.1.9188+add. & \\
\hline 3684 & 75 & (IGLS 13.2.9188) & 68 \\
\hline 3689 & $182 n 23$ & & \\
\hline $5071=$ ISchweiz 209 & $218 n 29$ & ILAfr 21.478 & 126 \\
\hline
\end{tabular}




\begin{tabular}{|c|c|c|c|}
\hline$I L C V 445^{1 b}$ & $10 n 24$ & 125 & 140n21 \\
\hline & & $127=$ IPOstie A279 & 139n18, \\
\hline ILS 986 & $38 n 46$ & & $140 n 21$ \\
\hline 1056 & $63 n 34$ & $128=$ IPOstie A146 & $140 n 23$ \\
\hline 1092 & 70055 & $129=$ IPOstie 147 & $140 n 23$ \\
\hline $1160-1$ & $73 n 66$ & $141=$ IPOstie A256 & $139 n 15$ \\
\hline 2288 & $62 n 29$ & & \\
\hline $235^{\circ}$ & $89 n 27$ & Lex repetundarum, $11.76-8$ & 228 \\
\hline 2726 & $55^{\mathrm{n} 1}$ & & \\
\hline 2735 & $55^{\mathrm{n} 1}$ & Lex Salp. $29=$ CIL 2.1963 = & \\
\hline 5864 & $73 n 67$ & FIRA I 202 & $225 \mathrm{n} 8$ \\
\hline $6753=$ IIt 11.1.6 & $217 \mathrm{n} 25$ & & \\
\hline 9487 & $111 n 39$ & Lex Urso 109 & $225^{n} 8$ \\
\hline $\operatorname{ISIS} 15^{\mathrm{gr}}-$ ISIS $20^{\mathrm{gr}}$ & 138,143 & $R G 21$ & $121 n 19$ \\
\hline $18^{\mathrm{gr}}$ & 143 n35 & $31-33$ & 116 \\
\hline $21=$ IPOstie A13 - & & & \\
\hline ISIS $133=$ IPOstie A122 & 138 & Res Gestae Divi Saporis 3-4 & $46 n 12$ \\
\hline $21=$ IPOstie A13 & $141-142$ & & \\
\hline $26=$ IPOstie A244 & 141 & RIB 665 & 62 \\
\hline $27=I P O s t i e$ A245 & $139 n 15$ & 814 & 65 \\
\hline 29 = IPOstie Ago & 138n15, 140n2o, & 1791 & 75 \\
\hline & $143 n 33$ & 1792 & $76 n 73$ \\
\hline $3^{2-33}=$ IPOstie A249-250 & $140 n 22$ & 1809 & $76 \mathrm{n} 73$ \\
\hline $34=$ IPOstie A171 & $141 n 29$ & $1845^{+a d d}$ & 66 \\
\hline $42=$ IPOstie A285 & $138 \mathrm{n} 14$ & 2138 & 68 \\
\hline $48=$ IPOstie $\mathrm{A}_{314}$ & $143 n 35$ & 2156 & 68 \\
\hline $49=$ IPOstie A212 & 143 & 2164 & 68 \\
\hline $50=$ IPostie A6o & 138n14, & & \\
\hline & 140n21 & $R I T 130=C I L 2^{2} / 14.975$ & $84 \mathrm{ng}$ \\
\hline $5^{1}=$ IPOstie A64 & $141 n 26$ & & \\
\hline $53=$ IPOstie A75 & 138n15 & $R M D 4.240$ & $67 n 46$ \\
\hline $78=$ IPOstie A239 & $141 \mathrm{n} 24$ & & \\
\hline $79=I P O s t i e \mathrm{~A} 238$ & $141 \mathrm{n} 24$ & SEG $9,35^{6}$ & 240 \\
\hline 82 & $141 \mathrm{n} 27$ & 9,414 & $240 n 76$ \\
\hline $87=I P O s t i e \mathrm{~A} 261$ & 140 21 & 27,1139 & $240 n_{7} 6$ \\
\hline 92 & $141 \mathrm{n} 26$ & 54,1625 & $229 n 31$ \\
\hline $93=$ IPOstie A17 & $141 \mathrm{n} 25$ & & \\
\hline 94 & $141 \mathrm{n} 25$ & $S G O$ 09/09/07 & $188-189$ \\
\hline $99=$ IPOstie A276 & 143n37 & & \\
\hline $106-107$ & $139 n 15$ & Tab. Heracl. $11.157=$ & \\
\hline $113=$ IPOstie A18o & $141 n 25$ & FIRA $\mathrm{I}^{2} 13$ & 230 \\
\hline $116=$ IPOstie A47 & 140 n20 & & \\
\hline $117=$ IPOstie A104 & $140 n 21$ & Tab. Siar. 2b. $24-26$ & $122 \mathrm{n} 21$ \\
\hline $119=$ IPOstie A77 & 140 21 & & \\
\hline $120=$ IPOstie A121 & $140 \mathrm{n} 23$ & $\operatorname{TAM} 5.1,607$ = Eck et. al., & \\
\hline 123 = IPOstie Ag6 & 140n21 & 'Sacrae Litterae', 365 & $107 \mathrm{n} 25$ \\
\hline $124=$ IPOstie A124 & $138 n 15$ & & \\
\hline & $140 n 20$ & $V A T 5660+$ & 30 \\
\hline
\end{tabular}


Veny Mélia, Corpus de las inscripciones Balearicas hasta la dominación arabe $21=$ Zucca, Insulae Baliares . Le isole Baleari sotto il dominio romano 25 112

3. Juridical Evidence

c.J. 6.1.3

10.32.31 \& 32.55

10.39.1

10.40

10.40.2 pr

$10.40 .2 \& 10.40 .7$

$10.61(59)$

10.66.1 = C.Th. 13.4 .2

C.Th. 6.37.1

8.1 .9

12.1.16 \& 12.1.76

12.12.6

14.9 .1

16.10 .20

Dig. 1.18.3

$3 \cdot 5 \cdot 3 \mathrm{pr}$

4.9.1.pr.-1

4.9.3.1

5.1.19.2

9.3.1.9

13.6 .5 .4

13.6.18.pr

13.7.43.1

27.1.6.7

27.1.13.7

31.34 .3

$33 \cdot 7.27 .1$

35.1.71.2

38.1.21

40.9.10

44.7.5 pr

45.1.137.2

$48.15 \cdot 7.2$

49.15 .5

$49.15 \cdot 7$

49.15.12

50.1.5
239-240

244ng1

244ng1

210n14

210n14

243n87

$192 n 6$

226n17

228n24

228

244ng1

238n71

$238 n 70$

238n7o

236n 57

$225 \mathrm{n} 13$

232n 41

232n 41

226-227

227

182

182

$9^{2} n_{3} 8$

220n33

182

224

224

237 n62

224

224

225-226

224

$236 n 57$

$233 n 46$

233

$233 n 47$

230

$5^{0.1 .17} \cdot 6$
$5^{0.1 .17} \cdot 11$
$5^{0.1 .27} \cdot 2$
$5^{0.1 .29}$
$5^{0.1 .31}$
$5^{0.1 .33}$
$5^{0.1 .34}$
$5^{0.1 .37}$
$5^{0.1 .38} \cdot 3$
$5^{0.2 .1 . p r}$.
$5^{0.3 .2 .1}$
$5^{0.16 .203}$
$5^{0.16 .239 .2}$

Gai. Instit. 1.185-186, 187

Gnomon of the Idios

$$
\text { Logos 64-66 237n66 }
$$

Just. Instit. 4.10.pr

Nov. 80, 9

NRN 2.9

$3.9 \& 3.10$

45-47

225ng

226n18, 239n72

159 n11

164

166

\section{Papyrological Evidence}

$B G U 1.24$
261
$2.372=$ SB 20.14662
$2.372=$ W. Chr. 19
3.855
4.1021
$4.105^{0}$
1074
6.1213
$6.125^{\circ}$
$7.1564=$ Sel. Pap. 2.395
7.1572
7.1680
$13.235^{\circ}$
15.2471

197 n311

188

197 n27

197 n28

197n31

197n31

12

242

$195 \mathrm{n} 17$

$195 \mathrm{n} 17$

9o, 201n49

196n26,

198n36, 201n49

198n36, 204n59

179

197n32, 204n 57

$C P L 117, \mathrm{~A}_{13} \& \mathrm{~B} 9$

66

Customs Account $\quad 162$ 


\begin{tabular}{|c|c|c|c|}
\hline \multirow[t]{2}{*}{ FIRA 3.25} & \multirow[t]{2}{*}{$225 \mathrm{n} 8$} & 8.1160 & $196 \mathrm{n} 26,198 \mathrm{n} 36$ \\
\hline & & 1259 & $237 n 66$ \\
\hline \multirow[t]{2}{*}{ O.Bu.Njem III, 71} & \multirow[t]{2}{*}{$240-241 n 77$} & 10.1296 & $198 n_{3} 6,204 n_{59}$ \\
\hline & & 12.1406 & 199n42 \\
\hline \multirow[t]{2}{*}{ P. Bingen 77} & \multirow[t]{2}{*}{162} & 13.6453 & $201 n 46$ \\
\hline & & $13.1175^{\circ}$ & $201 n 46$ \\
\hline \multirow[t]{2}{*}{ P. Bodl. 1.16} & \multirow[t]{2}{*}{ 197n31 } & 14.1634 & $204 n_{57}$ \\
\hline & & 14.1647 & 197 n1 \\
\hline \multirow[t]{2}{*}{ P. Bub. 1.212} & \multirow[t]{2}{*}{$197 \mathrm{n} 32$} & 14.1670 & $198 n_{3} 6$ \\
\hline & & 14.1678 & $198 n 36$ \\
\hline P. Col. 6.123 & $197 \mathrm{n} 28$ & $14.1705=$ Sel. Pap. 1.36 & $197 n 31$ \\
\hline \multirow[t]{2}{*}{$8.216=S B 5 \cdot 7661$} & \multirow[t]{2}{*}{ 198n36, 204n59 } & 14.1773 & 186 \\
\hline & & 22.2340 & 198 n34 \\
\hline \multirow[t]{2}{*}{ P. Dura $60 \mathrm{~B}$} & \multirow[t]{2}{*}{95} & 36.2755 & $192 n 6$ \\
\hline & & 38.2860 & $196 n_{2} 6,198 n_{3} 6$ \\
\hline \multirow[t]{2}{*}{ P. Fay. $59 \& 90$} & \multirow[t]{2}{*}{$204 \mathrm{n} 57$} & 41.2981 & $196 \mathrm{n} 26,198 \mathrm{n} 36$ \\
\hline & & 41.2983 & $196 n 26$ \\
\hline \multirow[t]{2}{*}{ P. Flor. 1.6} & \multirow[t]{2}{*}{$197 \mathrm{n} 27-28$} & $43 \cdot 3094$ & 199n42 \\
\hline & & $47 \cdot 3364$ & $197 \mathrm{n} 28,200 \mathrm{n} 43$ \\
\hline \multicolumn{2}{|l|}{ P. Giss $40 \mathrm{II}=$ Sel. Pap. $2.215=$} & $5^{1.3621}$ & 197n31 \\
\hline Chrest. Mitt. 377 & 191-204, 239 & 51.3626 & 197n31 \\
\hline 1.79 & $204 n_{5} 8$ & 66.4534 & $197 n 31$ \\
\hline \multirow[t]{2}{*}{$1.79 \mathrm{IV}$} & \multicolumn{3}{|l|}{$198 n 36$} \\
\hline & & PSI 3.162 & $198 n_{3} 6$ \\
\hline \multirow[t]{2}{*}{ P. Lips. 1.89} & \multirow[t]{2}{*}{$197 \mathrm{n} 31$} & 241 & $197 \mathrm{n} 31$ \\
\hline & & 1063 & 89 \\
\hline \multirow{3}{*}{$\begin{array}{l}\text { P. Lond. } 3.904=\text { W. Chr. } 202 \\
\begin{array}{l}3.904 \text { II } \\
1912=\text { Sel. Pap. } 1.212\end{array}\end{array}$} & $197 \mathrm{n} 28,202 n_{53}$ & $13.133^{2}=S B 5 \cdot 7992$ & $198 n_{3} 6,204 n_{59}$ \\
\hline & \multicolumn{2}{|l|}{$197 \mathrm{n} 27$} & \\
\hline & $241-242$ & P. Strasb. 7.618 & $197 \mathrm{n} 31$ \\
\hline P. Merton. 1.28 & $198 n_{3} 6,204 n_{59}$ & P. Tebt. 2.231 & 204 n 57 \\
\hline 2.83 & $198 n_{3} 6$ & 385 & $197 n 31$ \\
\hline & & $2.418 \mathrm{~V}$ & $198 n 36$ \\
\hline P. Mich. 1.123 & $204 n_{57}$ & & \\
\hline 2.214 & $182-183$ & P. Westminster Coll. 3 & $197 \mathrm{n} 28$ \\
\hline 3.121 & $198 n_{3} 6$ & & \\
\hline & & $S B 1.4284$ & 197n27-28, \\
\hline P.Oxy. 1.36 & $196 \mathrm{n} 26$ & & $200 n 43$ \\
\hline 1.99 & 204 n 57 & $5 \cdot 7662=$ P. Col. 8.225 & 198n36, 204n59 \\
\hline 2.294 & $196 \mathrm{n} 26$ & 5.8328 & 195 \\
\hline $2.25^{2}=$ W. Chr. 215 & $197 \mathrm{n} 27$ & $6.95^{26}=$ P. Col. 6.123 & $197 \mathrm{n} 28$ \\
\hline $2.253=197 \mathrm{n} 27$ & & $6.95542 \mathrm{c}$ & $204 n_{57}$ \\
\hline $3.487(156)=$ M. Chr. 322 & $198 n 35-36$ & 14.11575 & 197n31 \\
\hline $4 \cdot 744$ = Sel. Pap. 1.105 & $196 n 26$ & & \\
\hline $8.115^{8}$ & $196 \mathrm{n} 26$ & W. Chr. $22=$ Sel. Pap. 2.215 & $192 n 6$ \\
\hline & $198 n_{3} 6,204 n_{59}$ & & \\
\hline
\end{tabular}

